UNIVERSIDADE DE SÃO PAULO

FACULDADE DE ECONOMIA, ADMINISTRAÇÃO E CONTABILIDADE

DEPARTAMENTO DE ADMINISTRAÇÃO

PROGRAMA DE PÓS-GRADUAÇÃO EM ADMINISTRAÇÃo

COMPROMETIMENTO E GESTÃO DE PESSOAS EM EMPRESAS BRASILEIRAS COM ESTRUTURAS ORGANIZACIONAIS REMOTAS

NILDES RAIMUNDA PITOMBO LEITE

Orientador: Prof. Dr. Lindolfo Galvão de Albuquerque

SÃO PAULO 
Profa. Dra. Suely Vieira

Reitora da Universidade de São Paulo

Prof. Dr. Carlos Roberto Azzoni

Diretor da Faculdade de Economia, Administração e Contbilidade

Prof. Dr. Isak Kruglianskas

Chefe do Departamento de Administração

Prof. Dr. Lindolfo Galvão de Albuquerque

Coordenador do Programa de Pós-Graduação em Administração 


\title{
COMPROMETIMENTO E GESTÃO DE PESSOAS EM EMPRESAS BRASILEIRAS COM ESTRUTURAS ORGANIZACIONAIS REMOTAS
}

\author{
Tese de Doutorado apresentada ao \\ Departamento de Administração da Faculdade \\ de Economia, Administração e Contabilidade \\ da Universidade de São Paulo, como requisito \\ para obtenção do título de Doutora em \\ Administração.
}

Orientador: Prof. Dr. Lindolfo Galvão de Albuquerque

\section{SÃO PAULO}




\section{MEMBROS EFETIVOS (INTERNOS)}

Lindolfo Galvão de Albuquerque - FEA/USP - Professor Titular

Eduardo Pinheiro Gondim de Vasconcellos - FEA/USP - Professor Titular

Tania Casado - FEA/USP - Professora Doutora

MEMBROS EFETIVOS (EXTERNOS)

Antônio Virgílio Bittencourt Bastos - UFBA - Professor Titular

Darcy Mitiko Mori Hanashiro - U P Mackenzie - Professora Adjunta III MEMBROS SUPLENTES (INTERNOS)

Martinho Isnard Ribeiro de Almeida - FEA/USP - Professor Doutor

Sílvio Aparecido dos Santos - FEA/USP - Professor Titular

MEMBROS SUPLENTES (EXTERNOS)

Beatriz Maria Braga Lacombe - FGV SP - Professora Assistente

Carlos Alberto Freire Medeiros - UFRGN -Professor Adjunto ii

Leite, Nildes Raimunda Pitombo

Comprometimento e gestão de pessoas em empresas brasileiras com estruturas organizacionais remotas / Nildes Raimunda Pitombo Leite.

-- São Paulo, 2008.

$270 \mathrm{p}$.

Tese (Doutorado) - Universidade de São Paulo, 2008

Bibliografia.

1. Comprometimento organizacional 2. Administração de recursos humanos 3. Estrutura organizacional 4. Administração I. Universidade de São Paulo. Faculdade de Economia, Administração e Contabilidade II. Título.

CDD - 658.4094 
Aos meus pais, Nelson e Lourdes (in memorian), que dentro das possibilidades do amor, conceberam-me a dádiva de nascer. Aos meus filhos, Fábio, Fabrício e Tiago, que ampliaram as possibilides de manter-me renascendo nesse amor, a cada dia de incondicional apoio e segura amizade. 
Agradeço, muito em especial, aos professores: meu orientador, Lindolfo Galvão de Albuquerque, pelo apoio, encorajamento, paciência, dedicação e competência no processo de orientação desta tese; Eduardo Vasconcellos, pela colaboração valiosa na elaboração e refino conceitual em estrutura organizacional remota; Sílvio Aparecido dos Santos pela prestimosa ajuda na fase de preparação do projeto para a qualificação e pela confiança em minha possibilidade de colaborar com o Grupo de Pesquisas em Administração Avançada e Empreendedorismo - GPEADE; Tania Casado, pela crença nas minhas possibilidades e incremento de habilidades necessárias à caminhada; Adalberto Américo Fischmann e Martinho Isnard Ribeiro de Almeida, pela convivência diariamente encorajadora, atenciosa e amigável; Isak Kruglianskas, pelo incondicional incentivo durante toda a jornada; aos demais professores do Departamento de Administração, pelos sábios conhecimentos transmitidos dentro e fora das salas de aula. À FEA USP, pelo apoio institucional e pelas facilidades oferecidas. Aos funcionários do Departamento e da secretaria do PPGA - Programa de Pós-Graduação em Administração, pela cordialidade e presteza com que sempre me atenderam. Aos colegas do Grupo de Pesquisas em Gestão Estratégica de Pessoas, destacadamente: Sonia Regina Hierro Parolin, Ana Carolina Queiroz, Eduardo de Camargo Oliva e Marcos Abílio Bosquetti, pelo intercâmbio permanente e gentil; Leilianne Michelle Trindade da Silva, pela acolhida colaborativa para rever detalhes finais. Aos colegas do PPGA, especialmente, Victor de la Paz Richarte Martinez e Heidy Rodríguez Ramos, pelo convívio rico de trocas e profunda amizade; Ivan de Souza Dutra e Alex Antônio Ferraresi, pelo companheirismo nos empreendimentos conjuntos do GPEADE; Emerson Antonio Maccari, pelas conversas profícuas ao longo da finalização dessa jornada. Aos alunos do PET - Programa de Educação Tutorial da FEA USP, pela acolhida constante para um trabalho conjunto de crescimento e aprofundamento, ajudando-me a manter o foco no doutorado. Ao Professor José Carlos de Aquino, pela prestimosa ajuda na revisão gramatical. Às empresas integrantes do campo e, em particular, aos respondentes desta pesquisa em cada unidade, pela receptividade, cooperação facilitadora, competente e apoiadora. Aos meus familiares, detida e carinhosamente aos meus filhos, pelo desprendimento e estímulo permanente para a finalização desse ciclo. Agradeço, também, à FAPESP - Fundação de Amparo à Pesquisa do Estado de São Paulo, pelo apoio financeiro durante o período da pesquisa de campo desta tese, sem o qual não poderia torná-la viável. 
"A filosofia envolve, fundamenta e coroa o conjunto de ciências particulares".

Manuel Corrêa de Barros

“O caminho inclui o respeito por tudo que é pequeno e sutil".

Lao Tzu 


\section{RESUMO}

Esta pesquisa teve como objetivo investigar como a gestão de pessoas influencia o comprometimento organizacional dentro das unidades com estruturas organizacionais remotas. Sua importância reside na contribuição para a compreensão do que pode favorecer a retenção de talentos nessas unidades. Caracteriza-se como qualitativa, exploratória, baseada em estudo de casos múltiplos e cujo nível proposto de análise é o organizacional. Foi realizada por meio da aplicação de um levantamento de campo em algumas unidades de seis empresas autorizadas, cuja amostra envolveu grupos de análise constituídos de diretores, gerentes, RHs, supervisores e coordenadores de cada caso. O levantamento dos dados primários foi feito por meio de entrevistas em profundidade e observações nas áreas operacionais; o dos dados secundários, por meio de análise de documentos. $\mathrm{Na}$ análise dos resultados, trabalhou-se com as técnicas das análises de conteúdo, documental e reflexiva. Seus resultados demonstram a existência de práticas diferenciadas de gestão de pessoas, em razão das especificidades contextuais de cada unidade com estrutura organizacional remota, ficando em evidência que essa estrutura favorece a busca da contribuição e o desenvolvimento da solidariedade. Na visão dos respondentes, o nível de comprometimento organizacional é elevado, inserindo-se na perspectiva afetiva preconizada pela literatura. Tal perspectiva é sustentada pelos valores que ajudam a criar a identidade organizacional de cada uma dessas unidades, as quais tendem a aproximar as pessoas em todas as circunstâncias. Os gestores exercem influência direta no processo de obtenção desse comprometimento, facilitando para que esses valores sejam vivenciados por todos. Não obstante, os desafios para atração e retenção de talentos e suas famílias ainda permanecem, salvo nos casos em que os regimes de trabalho são diferenciados, em que as famílias permanecem em seus locais de origem e os atrativos financeiros e do próprio regime de trabalho compensam o afastamento temporário. As contribuições que esta pesquisa pode gerar são: auxiliar em futura análise da ligação entre a gestão de pessoas e o comprometimento organizacional, em novas unidades com estruturas organizacionais remotas no Brasil e em outros países; para a academia, poderá servir de estímulo para novas pesquisas nas áreas de administração, sociologia, psicologia, economia e antropologia; para as empresas, poderá ser feito um estudo comparativo das regiões onde elas tenham unidades remotas instaladas; para a sociedade, a possibilidade de retorno com os cuidados simultâneos que estão sendo tomados por essas organizações em todo o país.

Palavras-chave: Comprometimento Organizacional. Gestão Estratégica de Pessoas. Estruturas Organizacionais Remotas. 


\begin{abstract}
This study aimed to investigate how management influences people's organizational commitment within units with remote organizational structures. Its importance lies in contributing to the understanding of what might facilitate the retention of talent in these units. It is characterized as qualitative and exploratory, based on study of multiple cases, and its proposed level of analysis is organizational. It was realized by field studies in a few units of six companies, in which sample population involved focal groups consisting of directors, managers, human resources staff, supervisors, and coordinators of each case. The collection of primary data was done through in-depth interviews and observations in operational areas; the collection of secondary data was done through analysis of documents. For analysis of the results, techniques involving content, document, and reflective analyses were used. Results show the existence of different practices for managing people, due to the specific context of each unit, leaving in evidence that the remote organizational structure encourages the search for the contribution and development of solidarity. From the respondents' viewpoint, the level of organizational commitment is high, in line with the affective view advocated by the literature. This view is supported by the values that help create the identity of each of these organizational units, which tend to bring people together in all circumstances. The managers exert direct influence in the process of obtaining such commitment, facilitating everyone's experiencing of these values. Notwithstanding this influence, the challenges for attraction and retention of talent - and their families - still remain, except in cases where the work regimens are such that families remain in their places of origin and the financial incentives, as well as the work regimen itself, outweigh the worker's temporary absence from family life. The contributions that this research can generate are: aiding future analysis of the connection between management of people and organizational commitment in new organizational structures with remote units in Brazil and other countries; for academe, serving as a starting point for further research in the areas of administration, sociology, psychology, economics, and anthropology; for enterprises, serving as basis for a comparative study of the regions where they have remote units operating; to society, having the opportunity to benefit from actions being taken by these organizations throughout the country.
\end{abstract}

Keywords: Organizational Commitment. Strategic Management of People. Remote Organizational Structures. 


\section{SUMÁRIO}

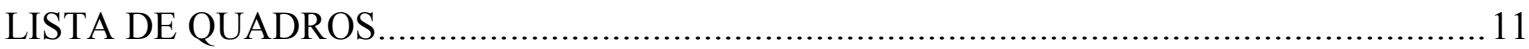

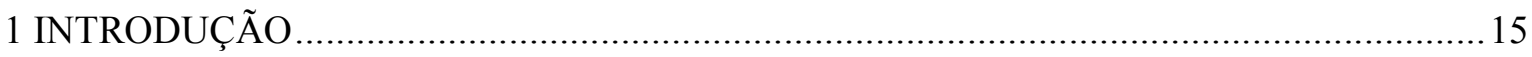

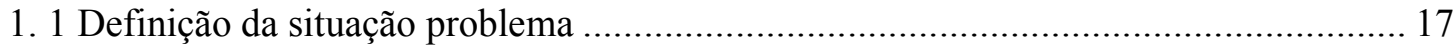

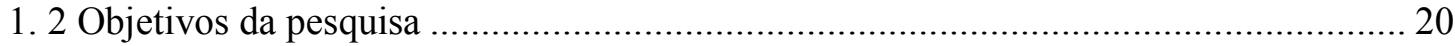

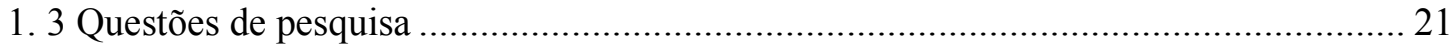

1. 4 Definições teóricas e operacionais dos termos relevantes da pesquisa ........................ 22

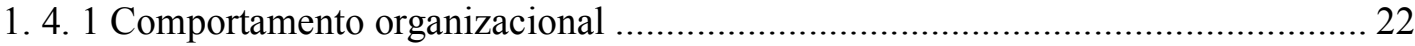

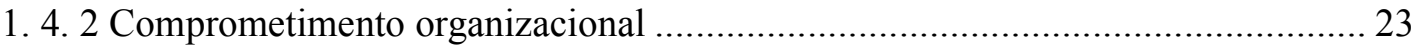

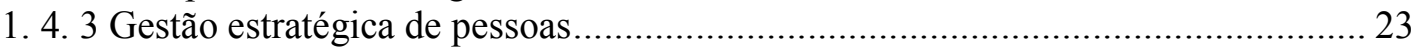

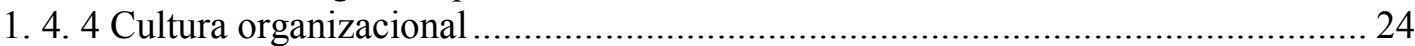

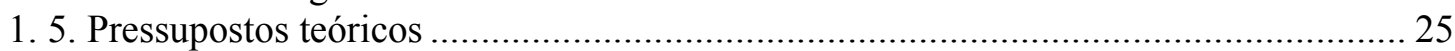

2 FUNDAMENTAÇÃO TEÓRICA DA PESQUISA ............................................................ 27

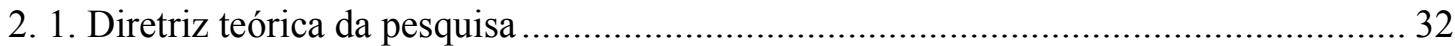

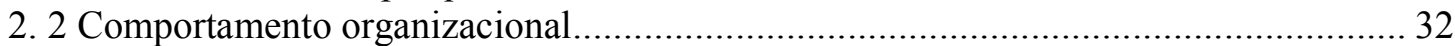

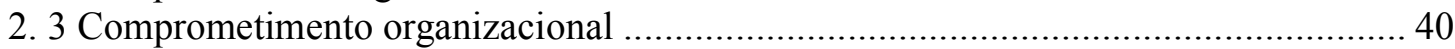

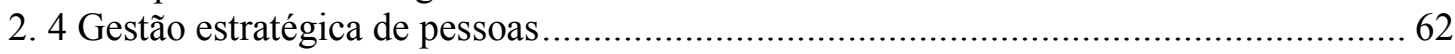

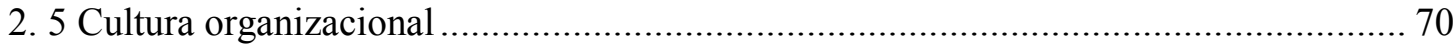

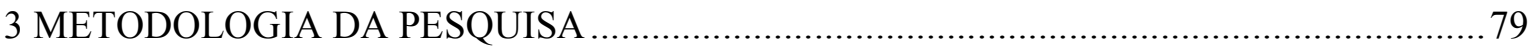

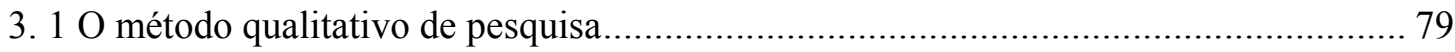

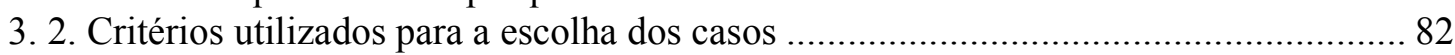

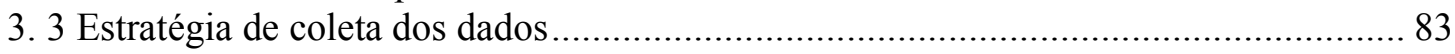

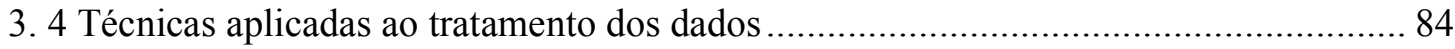

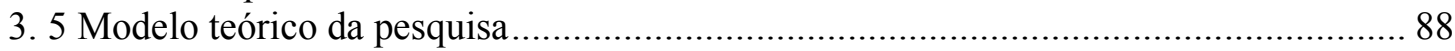

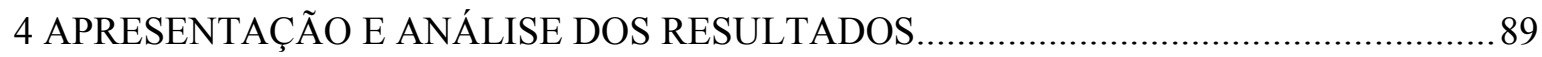

4. 1 Caso Companhia Vale do Rio Doce (Vale) ........................................................... 96

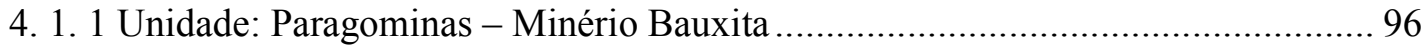

4. 1. 2 Unidade: Itabira - Minério Ferro - Minas Conceição e Cauê ............................ 103

4. 1. 3 Unidade: Porto Trombetas - Minério Bauxita .................................................. 109

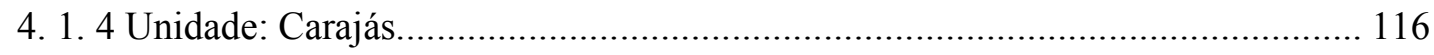

4. 1. 5 Unidade: Canaã dos Carajás - Mina Sossego …............................................... 123

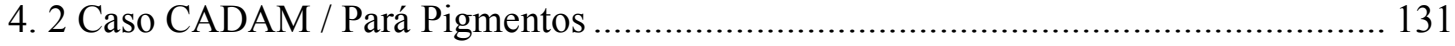

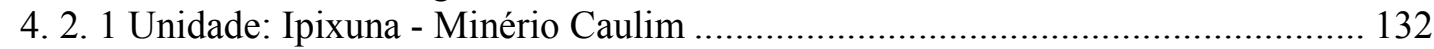

4. 2. 2 Unidade: Monte Dourado - Minério Caulim ................................................... 140

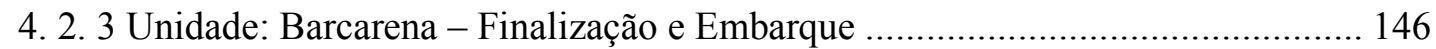

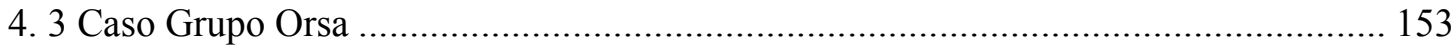

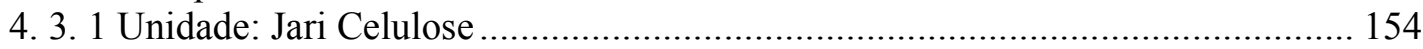

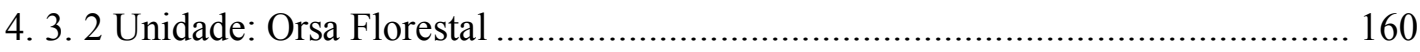

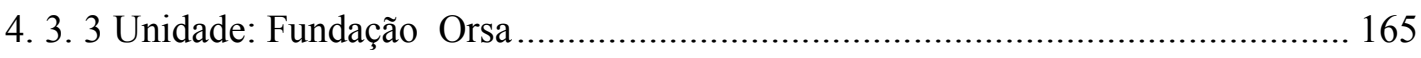

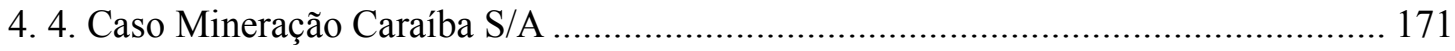

4. 4. 1 Unidade: Pilar - Jaguarari - Mina de Cobre ..................................................... 172 


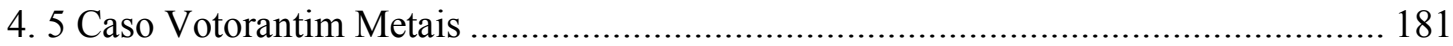

4. 5. 1 Unidade: Votorantim Metais Zinco e Cobalto - Niquelândia ........................... 183

4. 5. 2 Unidade: Votorantim Metais Zinco - Três Marias............................................. 189

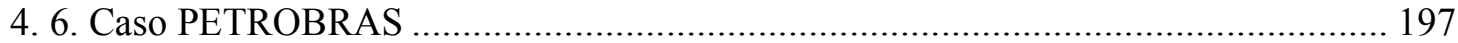

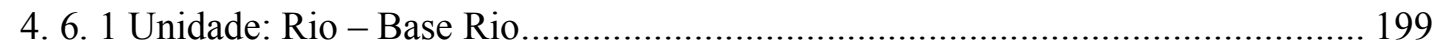

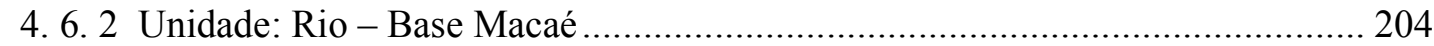

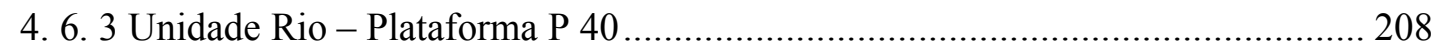

4. 6. 4 Unidade Rio - Plataforma P 38 .......................................................... 213

4. 6. 5 Unidade Rio - Plataforma P IV ................................................................... 218

4. 6. 6 Unidade Amazônia: Base Manaus................................................................. 222

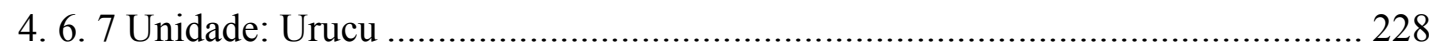

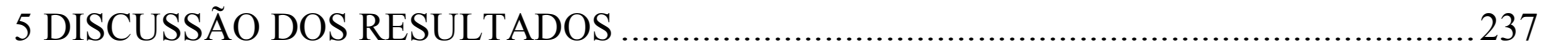

5.1 Limitações do estudo e contribuições para novas pesquisas....................................... 243

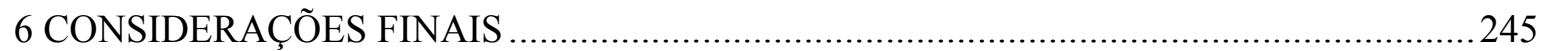

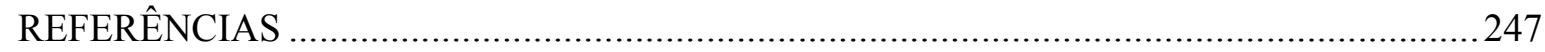

APÊNDICE 1 - ROTEIRO SEMI-ESTRUTURADO DA ENTREVISTA EM

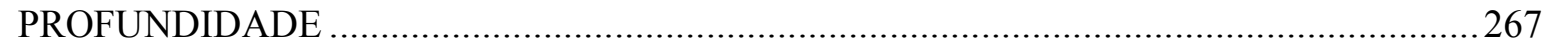

APÊNDICE 2 - ROTEIRO DE OBSERVAÇÕES ….......................................................2. 269 


\section{LISTA DE QUADROS}

QUADRO N 01

Fontes Teóricas e Enfoques

46

QUADRO N .02

Estudos Desenvolvidos no Brasil

QUADRO Nº 03

Amarrações da Pesquisa 88

QUADRO Nº 04

Caracterização das Empresas / Unidades Remotas 90

QUADRO Nº 05

Perfil dos Entrevistados 93

QUADRO Nº 06

Resultado da Análise de Conteúdo da Unidade Paragominas 97

QUADRO Nº 07

Resultado da Análise de Conteúdo Aplicado ao Escopo a Pesquisa Unidade Paragominas ... 99

QUADRO Nº 08

Resultado da Análise de Conteúdo da Unidade Itabira 104

QUADRO Nº 09

Resultado da Análise de Conteúdo Aplicado so Escopo da Pesquisa Unidade Itabira 106

QUADRO No. 10

Resultado da Análise de Conteúdo Unidade Porto Trombetas

QUADRO No. 11

Resultado da Análise de Conteúdo Aplicado ao Escopo da Pesquisa U. Porto Trombetas... 112

QUADRO N .12

Resultado da Análise de Conteúdo Unidade Carajás

QUADRO N 13

Resultado da Análise de Conteúdo Aplicado ao Escopo da Pesquisa Unidade Carajás 119

QUADRO N .14

Resultado da Análise de Conteúdo Unidade Canaã dos Carajás

QUADRO No. 15

Resultado da Análise de Conteúdo Aplicado ao Escopo da Pesquisa U. Canaã dos Carajás 126

QUADRO N 16

Resultado da Análise de Conteúdo Unidade Ipixuna 133 
QUADRO N. 17

Resultado da Análise de Conteúdo Aplicado ao Escopo da Pesquisa Unidade Ipixuna ....... 136

QUADRO No. 18

Resultado da Análise de Conteúdo Unidade Monte Dourado.

QUADRO No. 19

Resultado da Análise de Conteúdo Aplicado ao Escopo da Pesquisa U. Monte Dourado.... 143

QUADRO N. 20

Resultado da Análise de Conteúdo Unidade Barcarena

QUADRO N. 21

Resultado da Análise de Conteúdo Aplicado ao Escopo da Pesquisa Unidade Barcarena ... 149

QUADRO No. 22

Resultado da Análise de Conteúdo Unidade Jarí Celulose 155

QUADRO N. 23

Resultado da Análise de Conteúdo Aplicado ao Escopo da Pesquisa Unidade Jarí Celulose 157

QUADRO N .24

Resultado da Análise de Conteúdo Unidade Orsa Florestal

QUADRO N. 25

Resultado da Análise de Conteúdo Aplicado ao Escopo da Pesquisa U. Orsa Florestal....... 164

QUADRO N. 26

Resultado da Análise de Conteúdo Unidade Fundação Orsa 166

QUADRO No. 27

Resultado da Análise de Conteúdo Aplicado ao Escopo da Pesquisa Fundação Orsa 168

QUADRO N .28

Resultado da Análise de Conteúdo Unidade Pilar Jaguarari

QUADRO Nº 29

Resultado da Análise de Conteúdo Aplicado ao Escopo da Pesquisa U. Pilar Jaguarari ...... 175

QUADRO N 30

Resultado da Análise de Conteúdo Unidade Niquelândia 183

QUADRO N .31

Resultado da Análise de Conteúdo Aplicado ao Escopo da Pesquisa Unidade Niquelândia 186

QUADRO No. 32

Resultado da Análise de Conteúdo Unidade Três Marias 189

QUADRO N .33

Resultado da Análise de Conteúdo Aplicado ao Escopo da Pesquisa Unidade Três Marias. 192 
QUADRO N 34

Resultado da Análise de Conteúdo Unidade Rio Base Rio 199

QUADRO No. 35

Resultado da Análise de Conteúdo Aplicado ao Escopo da Pesquisa U. Rio Base Rio 201

QUADRO No. 36

Resultado da Análise de Conteúdo Unidade Rio Base Macaé 205

QUADRO N .37

Resultado da Análise de Conteúdo Aplicado ao Escopo da Pesquisa U. Rio Base Macaé ... 207

QUADRO N .38

Resultado da Análise de Conteúdo Unidade Rio Plataforma P 40 209

QUADRO N. 39

Resultado da Análise de Conteúdo Aplicado ao Escopo da Pesquisa U. Rio Plat. P 40 ....... 211

QUADRO No. 40

Resultado da Análise de Conteúdo Unidade Rio Plataforma P 38.

QUADRO N .41

Resultado da Análise de Conteúdo Aplicado ao Escopo da Pesquisa U. Rio Plat. P 38 ....... 216

QUADRO N .42

Resultado da Análise de Conteúdo Unidade Rio Plataforma P IV 218

QUADRO N .43

Resultado da Análise de Conteúdo Aplicado ao Escopo da Pesquisa U. Rio Plat. PIV

QUADRO No .44

Resultado da Análise de Conteúdo Unidade Amazônia Base Manaus.

QUADRO N .45

Resultado da Análise de Conteúdo Aplicado ao Escopo da Pesquisa U. Am. Base Manaus 225

QUADRO N .46

Resultado da Análise de Conteúdo Unidade Amazônia Base Urucu

QUADRO N .47

Resultado da Análise de Conteúdo Aplicado ao Escopo da Pesquisa U. Am. Base Urucu... 231 


\section{INTRODUÇÃO}

As organizações contemporâneas têm passado por permanentes ajustes na busca de atendimento aos desafios que lhes são impostos pelas constantes e rápidas transformações da sociedade pós-industrial. Essas transformações propostas, não raro, afetam diretamente o comprometimento do trabalhador com a organização.

As organizações em transformação, por sua vez, requerem pessoas qualificadas e comprometidas com o processo produtivo, em lugar de recursos humanos alienados, desmotivados e despreparados.

Tais mudanças, também, têm instigado pesquisadores a estudarem o comprometimento organizacional com vistas à compreensão das variáveis principais que explicam o comportamento humano no trabalho.

As organizações precisam saber aonde querem chegar, o que significa definir a gestão que querem construir, realizar visão, missão, objetivos e metas, o que implica: a necessidade de escolha de estruturas, tecnologias e estratégias; o reconhecimento da relevância de compartilhamento de visão, missão, objetivos, metas, estruturas, tecnologias e estratégias; o pensar o comprometimento como fruto desse compartilhamento.

Dentre as mudanças ocorridas no setor industrial, encontram-se as implantações de unidades com estruturas organizacionais remotas, o que exige pessoas dispostas a enfrentar o desafio oriundo dessas mudanças, em virtude das especificidades operacionais e das regiões onde tais unidades são instaladas.

Para clarificar o conceito de estrutura organizacional remota, elaborado com a colaboração do professor Eduardo Vasconcellos, primeiro, por estrutura organizacional entenda-se a escolha da melhor forma para o agrupamento de recursos humanos e materiais (departamentalização), assim como a definição de autoridade, atividades e comunicação (atribuições), necessárias para cumprir a missão da organização. 
Há situações em que a empresa cria uma infra-estrutura necessária à instalação das pessoas em uma dada região, distante dos grandes centros, para operar suas unidades lá instaladas. A estrutura organizacional (departamentalização e atribuições) para gerenciar essa infraestrutura será doravante denominada estrutura organizacional remota.

Essa infra-estrutura pode compreender: obras rodoviárias, usina hidrelétrica, atividades de pecuária, agronomia, construção de hotel, residências, farmácia, cinema, escola, detenção, desenvolvimento de comércios, pequenas indústrias, dentre outras, que venham dar sustentação à coletividade a ser para lá transferida. Tais instalações de unidades remotas, por seu turno, exigem análise acurada para que as decisões sejam tomadas levando-se em consideração os fatores envolvidos que podem vir a afetar o comprometimento do trabalhador com a organização.

O comprometimento organizacional associado à gestão estratégica de pessoas é um assunto que vem ganhando cada vez mais espaço na literatura. Muitos estudos explicitados na fundamentação teórica desta pesquisa, entretanto, apontam a ausência de consenso acerca do constructo comprometimento organizacional e o referenciam como um conceito em construção.

A gestão estratégica de pessoas contempla o estudo do conjunto de políticas, práticas e instrumentos, definidos por uma organização para pautar o comportamento humano e as relações interpessoais no ambiente de trabalho e busca a interação interdisciplinar para a compreensão do comportamento organizacional.

Comportamento humano, comprometimento organizacional, gestão estratégica de pessoas e cultura organizacional são conceitos ligados diretamente às pessoas e pessoas necessitam de estruturas para que possam pôr em prática os seus talentos potenciais.

Organizações, de acordo com Nadler, Hackman e Lawler III (1983) são sistemas sociais que têm de transacionar com um ambiente externo, constituídas de indivíduos e grupos que desempenham tarefas e têm arranjos organizacionais formais e informais. Os indivíduos nas organizações estão ligados de modo coordenado para facilitar o desempenho organizacional. A presente pesquisa assume que a organização pode ser compreendida como uma entidade 
que interpreta o ambiente que a circunscreve, ao mesmo tempo em que o constrói por intermédio de suas ações, de acordo com Vasconcelos (2004).

\section{1 Definição da situação problema}

Buscou-se, em um primeiro momento, compreender as origens da discussão sobre os temas integrantes desta pesquisa para em seguida identificar os motivos e justificativas que conduziam os autores estudados a observar os fenômenos do comprometimento nas organizações e da gestão de pessoas com distintos olhares.

Dentre as correntes conceituais oriundas da sociologia, das teorias organizacionais e da psicologia social (exploradas mais detidamente no capítulo da Fundamentação Teórica), que marcam as abordagens de comprometimento nas organizações, destaca-se a que trata dos enfoques afetivo, instrumental e normativo, por um lado e, por um outro, ainda como campo aberto para aprofundar as pesquisas, a corrente que começa a tratar do enfoque comportamental.

É factível perceber, ao buscar pesquisar os enfoques, que as abordagens podem apresentar-se como complementares e encontram ressonância entre os pesquisadores brasileiros.

Dentro do escopo desta pesquisa, procurou-se sistematizar uma série de artigos e livros que versam sobre o tema. Muitos deles, citados ao longo deste trabalho, trazem contribuições significativas para futuros estudos, particularmente no Brasil, e representam, certamente, o estado-da-arte à leitura proposta do fenômeno do comprometimento organizacional.

Como a pesquisa de campo deu-se em unidades com estruturas organizacionais remotas, justifica-se uma leitura preliminar do contexto de estruturas organizacionais, bem como uma rápida incursão às principais teorias que marcam a discussão sobre o comprometimento nas organizações, seus pressupostos relevantes e seus vínculos com a questão da gestão de pessoas para, enfim, justificar a opção de abordagem ao fenômeno, proposta.

São características evidenciadas da complexidade do ambiente organizacional: turbulência, incerteza, mudanças tecnológicas aceleradas, incremento da internacionalização dos negócios, aumento da defasagem entre países mais e menos desenvolvidos, aumento do número de 
escolas de Administração e, em conseqüência, de administradores profissionais, papel do Governo, tamanho e complexidade das organizações, evolução do sindicalismo, preocupação com a ecologia, com a substituição de fontes de energia e proteção ao consumidor. (VASCONCELLOS e HEMSLEY, 2003).

Dada a tal complexidade, responsável, em muitos casos, pelo impacto das mudanças nas estruturas tradicionais, surgem as estruturas organizacionais inovativas. Para esses autores, as diferenças entre as organizações, cujas estruturas mostram tanto os modelos mecanicistas quanto os do tipo orgânico, são observadas, associando-se aos aspectos da inovação, crescimento e satisfação das pessoas.

Ainda em face da complexidade desse ambiente, o conceito de estrutura organizacional deve envolver os subsistemas de autoridade, de comunicação e de atividades, os quais precisam estar em constante interdependência. As estruturas organizacionais compreendem, por sua vez, características tradicionais e inovativas.

Para a formação de uma estrutura organizacional, aspectos como: definição das atividades, escolha dos critérios de departamentalização, definição quanto à centralização $x$ descentralização de áreas de apoio, localização de assessorias, decisão quanto à amplitude de controle e ao número de níveis hierárquicos, definição do nível de descentralização de autoridade, sistema de comunicação e definição quanto ao grau de formalização, necessitam estar em interação.

As características das estruturas organizacionais tradicionais envolvem informações acerca da estrutura formal x informal, unidade de comando x nível de conflitos, especialização elevada, ênfase na comunicação vertical e utilização de formas tradicionais de departamentalização, cujos critérios mais tradicionais são: funcional, geográfico, por processo, por cliente, por produtos, por período e pela amplitude de controle (VASCONCELLOS e HEMSLEY, 2003).

Esses autores enfatizam que o conceito de estrutura organizacional, além de envolver os subsistemas de autoridade, de comunicação e de atividades, sugere que a decisão de descentralização da autoridade deve ser tomada considerando os efeitos tanto das decisões excessivamente centralizadas no topo da hierarquia quanto do excesso de descentralização. 
A estratégia de gestão de pessoas pode variar de acordo com a forma como as organizações estejam estruturadas. As estruturas organizacionais tradicionais "são as formas clássicas desenvolvidas em ambientes estáveis, caracterizadas por rigidez e padronização, ou seja, apresentam visão estática ou mecânica da organização." As estruturas inovativas "são formas novas, mais ativas e dinâmicas, que respondem ou se adaptam às constantes mudanças do contexto das organizações." (OLIVARES, 1999, pp. 36-44). Essas estruturas tradicionais resultam da "utilização das formas convencionais de departamentalização." (VASCONCELLOS e HEMSLEY, 1986, p. 8).

Inversamente àquelas características estruturais apresentadas pelas organizações tradicionais, as organizações inovativas são mostradas com baixo nível de formalização, formas avançadas de departamentalização, multiplicidade de comando, diversificação elevada, comunicação horizontal e diagonal.

De acordo com Olivares (op. cit.), no desenvolvimento de uma estrutura organizacional, devem-se considerar seus componentes, condicionantes e níveis de influência. Para o delineamento de uma estrutura, deve-se realizar uma análise técnica e consciente com referência aos elementos que servem como base para que a organização funcione segundo parâmetros influenciados por critérios de dentro e de fora das organizações.

A decisão de instalação de unidades remotas recebe a influência desses critérios e é tomada com base nos níveis estratégico, tático e operacional da organização. Oliveira (2004) salienta que o nível estratégico considera a estrutura organizacional de toda a organização e a sua melhor interação com o ambiente. O tático inclui cada área da organização, com uma visão integrada de todas as operações e a maximização dos resultados delas. O operacional considera o modelo, a definição de metas, a mediação, a comparação e o feedback do desempenho das operações, a fim de otimizar a execução das atividades organizacionais. A estrutura organizacional remota foi considerada como critério de escolha do universo da pesquisa.

No que tange ao termo comprometimento organizacional, alguns autores (BASTOS, 1994 a; CHANG, 2001; MEDEIROS, 2003) apontam para a necessidade de pesquisas exploratórias com abordagem qualitativa que investiguem, com profundidade, o fenômeno do comprometimento organizacional, a fim de compreender sua relação com o contexto das organizações em suas estratégias de gestão de pessoas. 
Por seu turno, a gestão estratégica de pessoas nas organizações é um tema recorrente e desafiador para os pesquisadores, diante da crescente descoberta da necessidade de valorização do intangível: o capital humano como fonte de valor e de competitividade organizacional (ALBUQUERQUE, 1999; ULRICH, 2000). O comprometimento organizacional e a gestão estratégica de pessoas, no contexto das unidades com estruturas organizacionais remotas, ainda são uma grande lacuna a ser explorada largamente. Essa questão pode representar uma primeira contribuição a ser empreendida por esta pesquisa.

Não foi encontrada, na literatura, referência ao conceito de estruturas organizacionais remotas. No entanto, essas estruturas organizacionais remotas encontram-se instaladas em várias unidades de organizações brasileiras geograficamente distantes dos gramdes centros urbanos. O mais próximo das organizações com unidades organizacionais remotas, encontrado nas pesquisas bibliográficas, refere-se ao trabalho de Owen, considerado um socialista utópico por Heilbroner (1996), o qual traz o conceito proposto por Owen como 'Aldeias de Cooperação'. A definição operacional pode estar contida no conceito teórico de estruturas inovativas e/ou no conceito teórico de estruturas tradicionais. Dessa forma, esta pesquisa também pode contribuir, ao construir um conceito teórico já operacionalmente existente.

Esta pesquisa pode, por fim, contribuir para o refinamento do conceito de comprometimento organizacional, na medida em que autores como Borges-Andrade; Cameschi; Silva (1989) referem-se ao estudo do comprometimento organizacional como escasso no Brasil e Bastos (1994 a) ressalta a redundância, a ambigüidade e a imprecisão dos conceitos existentes nas definições do comprometimento organizacional. É importante salientar que, os resultados de uma pesquisa exploratória como esta, podem aprimorar idéias e propor novas questões para futuras pesquisas.

\section{2 Objetivos da pesquisa}

Considerando-se as diretrizes teóricas adotadas e que a estrutura organizacional remota foi o critério de seleção do universo desta pesquisa, em função das especificidades nela contidas, o principal objetivo pode ser, assim, enunciado: 
Investigar como a gestão de pessoas influencia o comprometimento organizacional dentro das unidades remotas.

Essa investigação visa a contribuir para a compreensão do que pode favorecer a retenção de talentos em suas unidades remotas.

Em âmbito maior, também poderá vir a contribuir em prol do desenvolvimento regional, nas regiões onde as unidades organizacionais analisadas estão inseridas.

Para a consecução desse objetivo de investigação, esta pesquisa tomou como objetivos específicos:

Descrever e analisar características da estratégia de gestão de pessoas e do comprometimento organizacional no contexto das unidades remotas analisadas;

Identificar as práticas de gestão de pessoas que facilitam ou dificultam o comprometimento organizacional dessas unidades;

Caracterizar o ambiente interno (cultura organizacional e estrutura organizacional) de unidades das organizações selecionadas para a pesquisa, procurando identificar diferenças regionais;

Identificar a estratégia de comunicação e o comportamento organizacional de unidades das organizações selecionadas para a pesquisa.

\section{3 Questões de pesquisa}

Uma questão principal de pesquisa e outra auxiliar foram formuladas, com base nos fatores que podem facilitar ou dificultar a estratégia de gestão de pessoas e a obtenção do comprometimento organizacional nas diferentes unidades organizacionais remotas e suas especificidades, a seguir enunciadas: 
Como a gestão de pessoas facilita ou dificulta a obtenção do comprometimento organizacional nas unidades das organizações pesquisadas?

Existem diferenças entre as culturas das unidades remotas dessas organizações? Quais são as diferenças e como elas se evidenciam?

\section{4 Definições teóricas e operacionais dos termos relevantes da pesquisa}

A seguir, encontram-se as definições teóricas e operacionais dos termos considerados relevantes para esta pesquisa.

\section{4. 1 Comportamento organizacional}

As definições teóricas desse termo estão aqui colocadas em razão de: a primeira apresentar conteúdos de pessoas e estruturas, que se complementam e, ao mesmo tempo, podem ser isolados didaticamente para investigação pormenorizada; a segunda enfocar, de modo abrangente, os elementos oriundos dos indivíduos e grupos.

Teoricamente, comportamento organizacional pode ser definido como:

"um campo de estudo que investiga o impacto que indivíduos, grupos e a estrutura têm sobre o comportamento dentro das organizações, com o propósito de utilizar esse conhecimento para promover a melhoria da eficácia organizacional.” (ROBBINS 2002, p.6). "O estudo do conjunto de ações, atitudes e expectativas humanas dentro do ambiente de trabalho." (LIMONGI-FRANÇA, 2006, p. 3).

A expressão comportamento organizacional é comumente utilizada em todo o mundo para denominar as habilidades humanas, incluindo motivações, comportamentos, comunicações intra e interpessoal, desenvolvimento de atitudes, poder de liderança, estruturas e processos grupais, percepção, aprendizado, conflitos, mudança, planejamento e organização humana do trabalho.

Operacionalmente, o comportamento organizacional foi analisado nas unidades remotas das organizações pesquisadas, pela presença de pessoas responsáveis pelo gerenciamento das 
expectativas das relações de trabalho, processos de cooperação, apatia e competição, grupos, equipes e times de trabalho, cultura organizacional e valores.

A presença de elementos que integram o comportamento organizacional foi constatada por intermédio de alguns indicadores de atividades gerenciais que evidenciam as práticas dos gestores, ou seja: facilitação do trabalho em equipe, formação de times de trabalho, valorização do indivíduo.

\section{4. 2 Comprometimento organizacional}

As definições teóricas de comprometimento organizacional foram escolhidas considerando-se o fato de que a primeira apresenta uma conceituação genérica, enquanto a segunda apresenta uma conceituação mais focada na literatura clássica do tema.

Teoricamente, o comprometimento pode ser definido como: "termos internalizados pelos indivíduos em suas motivações, orientações e comportamentos relacionados à organização." (GOULDNER, 1960, p. 469). "Na linguagem científica, o comprometimento é empregado por diversos autores como: o desejo de permanecer como membro da organização; o orgulho por pertencer a uma organização; a identificação com objetivos, metas e valores da organização; o engajamento, o esforço, o empenho exercido em favor da organização.” (CHANG, 2001, p. 2).

Operacionalmente, o comprometimento organizacional foi constatado nas unidades das organizações cujos casos foram estudados, pela busca de compreensão do indivíduo no seu contexto de trabalho conhecendo as variáveis que o motivam, o engajam e o tornam produtivo para a organização. A presença do comprometimento foi constatada por intermédio de indicadores de atividades individuais ou de grupo, a exemplo da performance dos indivíduos no trabalho, da produtividade obtida e da qualidade dos produtos finais.

\section{4. 3 Gestão de pessoas}

As definições teóricas desse termo estão aqui colocadas em razão dos aspectos da subjetividade humana contida na primeira e da fácil visualização da operacionalidade da segunda. Em termos teóricos, gestão de pessoas pode ser definida como: 
"[...] uma forma constantemente renovada de pensar a atuação e a interação humana na organização, reconhecendo o que é uno e múltiplo no ser humano, mostrando como todo fenômeno estudado é perpassado pela subjetividade, reafirmando o papel da pessoa, de sua experiência, do simbólico nas organizações e, ao mesmo tempo, restituindo a pessoa ao seu quadro sociohistórico." (DAVEL e VERGARA, 2001, p. 50). O Programa de Estudos em Gestão de Pessoas concebe que "a partir de enfoque sistêmico e estratégico, a gestão de pessoas compreende o conjunto de políticas, práticas e instrumentos, definidos por uma organização, para pautar o comportamento humano e as relações interpessoais no ambiente de trabalho.” (PROGEP / FIA, 2006).

Operacionalmente, a gestão de pessoas foi constatada nessas unidades remotas estudadas, pela presença de pessoas dedicadas ao gerenciamento dos processos de recrutamento, seleção, contratação, remuneração, avaliação e promoção, adaptação, treinamento e desenvolvimento.

A presença da gestão de pessoas foi constatada por meio de alguns indicadores de atividades quais sejam: coordenação de subestruturas, planejamento das ações de desenvolvimento, resolução de conflitos, coordenação dos requisitos exteriores com os recursos e as necessidades da organização, adoções de novas práticas de gestão, transmissão e manutenção dos valores, da missão e da visão.

\section{4. 4 Cultura organizacional}

A escolha das definições teóricas para esse termo recaiu no fato de elas apresentarem elementos de caráter complementar. Em termos teóricos, cultura organizacional pode ser definida como:

“O conjunto de pressupostos básicos que algum grupo inventou, descobriu ou desenvolveu ao aprender como lidar com os problemas de adaptação externa e integração interna, de tal modo que, se os pressupostos funcionaram suficientemente bem, foram considerados válidos e ensinados a novos integrantes como a forma correta de perceber, pensar e sentir, em relação a esses problemas.” (SCHEIN, 1985, p. 9). "O conjunto de valores e pressupostos básicos expresso em elementos simbólicos que, em sua capacidade de ordenar, atribuir significações, construir a identidade organizacional, 
tanto agem como elemento de comunicação e consenso, como ocultam e instrumentalizam as relações de dominação" (FLEURY e SAMPAIO, 2002, p. 293).

Operacionalmente, a cultura organizacional foi constatada nas unidades das organizações cujos casos foram estudados, pela presença de pessoas que cuidam das políticas de gestão de pessoas, dos programas estratégicos de recursos humanos e do alinhamento com a estratégia organizacional. As características da cultura organizacional foram constatadas através de alguns indicadores de atividades gerenciais que revelem as práticas de gerenciamento, ou seja: difusão da visão, filosofia de atuação, missão e valores.

Os quatro termos relevantes contidos nesse item, com a finalidade de apresentar, de forma sinóptica, as definições teóricas e operacionais, serão desenvolvidos no capítulo 2: Fundamentação Teórica da Pesquisa.

\section{5. Pressupostos teóricos}

Tomando-se, ainda, por base o nível de análise (organizacional) e os termos considerados relevantes no item 1.4, (comportamento organizacional, comprometimento organizacional, gestão de pessoas e cultura organizacional), passa-se à listagem dos pressupostos teóricos assumidos nesta pesquisa.

As organizações são sistemas de pessoas, com caráter permanente, que visam realizar um propósito e que contribuem para que elas tenham um modo de vida, desempenhando uma função social. (PEREIRA, 2004);

A suposição é que se comportamentos novos são aprendidos, se os indivíduos os desejam implementar e se os indivíduos se permitem fazê-lo, então, pelo contexto, eles o farão. (ARGYRIS, 1993);

A formação ou operacionalização do comprometimento do colaborador ocorre em ambiente dinâmico, que exige freqüente atualização e enriquecimento da teoria e da prática relacionadas a esse constructo. (CHANG, 2001); 
Para a formulação da estratégia de gestão de pessoas interessa aprofundar os aspectos relativos às dimensões humanas, ou seja, a cultura e as pessoas, e como a interação das pessoas com a estrutura e com o sistema pode contribuir para a consecução dos objetivos estratégicos da organização. (ALBUQUERQUE, 2002);

Uma forte cultura pressupõe o comprometimento dos empregados com os objetivos organizacionais (FLEURY; FLEURY, 1997).

Esses pressupostos teóricos, aqui assumidos e apresentados, serão revistos, desenvolvidos e aprofundados no Capítulo 2. Fundamentação Teórica da Pesquisa. 


\section{FUNDAMENTAÇÃO TEÓRICA DA PESQUISA}

Uma vez delimitados os problemas de pesquisa e assumidos os pressupostos teóricos, buscase evidenciar a fundamentação teórica pertinente, a fim de construir a base conceitual em que esta pesquisa se apoiou. Essa fundamentação está pautada nos termos relevantes definidos teórica e operacionalmente na seção 1.4., quais sejam: comportamento organizacional, comprometimento organizacional, gestão estratégica de pessoas e cultura organizacional, com uma breve reapresentação de alguns nomes que iniciaram as pesquisas envolvendo contribuições para esses termos, tomando-se por base vários autores, dentre eles (DAVIS, 1957; SMITH, 1996; PEREIRA, 2004).

No contexto de organizações, em 1776, quando Adam Smith demonstrou que a divisão do trabalho aumenta a produtividade porque melhora as habilidades e a agilidade de cada trabalhador, economiza o tempo perdido nas mudanças de tarefas e encoraja a criação de maquinários e outras invenções que ajudam a mão-de-obra, reforçando que as pequenas manufaturas servem melhor de base para as observações, vez que as grandes não concentram grande número de pessoas em um mesmo local, pode ter aberto a senda para os estudos organizacionais, como se apresentam nos dias atuais.

A preocupação com a gestão organizacional ficou evidenciada com as observações de Robert Owen em 1789 quando, aos dezoito anos, comprou sua fábrica. Em 1825, Owen foi considerado idealista porque acreditou ser possível um ambiente de trabalho capaz de amenizar o sofrimento da classe trabalhadora com a regulamentação das horas de trabalho para todos, criação de leis específicas para os menores de idade, promoção da educação pública, refeitório nas fábricas e envolvimento das organizações em projetos para o bem da comunidade. Owen pode ter contribuído para o estudo das políticas de gestão como é desenvolvido hoje.

A gestão de pessoas já pôde ser observada com o trabalho de Charles Babbage em 1832, ao expandir a lista de qualidades oriundas da divisão do trabalho iniciada por Adam Smith em 1776, incluindo: a diminuição do tempo necessário para o aprendizado da função; a redução do desperdício de material durante o período de aprendizado; a obtenção de altos níveis de habilidades; a melhoria na adequação entre as habilidades e as capacidades físicas das pessoas 
ante as tarefas específicas. O trabalho de Babbage elucidou a igual relevância dos trabalhos mental e físico.

O desafio do comprometimento das pessoas com as organizações, o aprofundamento do que viria a ser a gestão estratégica de pessoas, os componentes do comportamento humano e do comprometimento já puderam ser vislumbrados a partir da era clássica, a qual trouxe, entre 1900 e 1930, alguns nomes que deixaram marcas na história organizacional, com a fundação das práticas contemporâneas da administração.

Na linha de produção em série de Henry Ford, o comprometimento do trabalhador foi uma preocupação inexistente e, nessa perspectiva, aumentou a alienação, em virtude da repetição de movimentos padronizados.

$\mathrm{Na}$ abordagem da Administração Científica trazida por Frederick Winslow Taylor e nos princípios por ele preconizados, encontra-se a inclusão de fatores como treinar, ensinar e aperfeiçoar o trabalhador; cooperar cordialmente com ele e definir deveres e responsabilidades. Esses fatores elucidados por Taylor evidenciam contribuições ao estudo do comprometimento dos colaboradores.

Com Henri Fayol veio a sua teoria da administração englobando as atividades de planejar, organizar, comandar, coordenar e controlar. Com relação à divisão do trabalho enfatizada por Adam Smith, Fayol reforçou os princípios da autoridade, disciplina, unidade de comando, unidade de direção, subordinação dos interesses pessoais aos interesses da organização, remuneração, centralização, cadeias de autoridade, ordem, eqüidade, estabilidade de pessoal, iniciativa e espírito de equipe. Ainda que de modo implícito, o comprometimento foi trazido nos princípios relacionados por Fayol, como remuneração de pessoal, ordem, equidade, estabilidade pessoal, iniciativa, união do pessoal.

A visão mecanicista e impessoal da organização foi mostrada por Max Weber, que enfatizou a teoria estrutural, em que as estruturas de autoridade norteiam as atividades organizacionais. Como o primeiro a olhar o comportamento organizacional sob uma perspectiva estrutural, introduziu o conceito da burocracia e junto com ele a especialização do trabalho, a hierarquia de autoridade, a seleção formal, as regras e regulamentos formais, a impessoalidade e a orientação de carreira. 
A teoria do homem social, reconhecida em 1930 e de autoria de Mary Parker Follet, uma das primeiras autoridades a constatar que as organizações podem ser vistas na perspectiva do comportamento individual ou de grupo, trouxe a base ética de grupo e não de individualismo, em que administradores e trabalhadores devem se ver como parceiros. Follet enfatizou o esforço de equipe e a unidade grupal.

Com pesquisas realizadas entre 1909 e 1938, Chester Barnard enfatizou que as organizações são sistemas sociais que requerem a cooperação humana. Barnard ressaltou a necessidade de interação com o ambiente externo da organização.

A era do comportamento, também ficou conhecida desde 1900, com o aparecimento do departamento de pessoal, com vistas a melhorias nas condições de trabalho, moradia, assistência médica, educação, recreação. A psicologia industrial, introduzida por Hugo Münsterberg em 1913, reforçou o estudo científico do comportamento humano, por identificar padrões gerais e diferenças individuais.

O período considerado das relações humanas foi marcado pelo novo direcionamento do comportamento organizacional e das práticas da administração. Os estudos em Hawthorne, de 1924 a 1932, com a participação de Elton Mayo a partir de 1927, despertaram o interesse sobre o fator humano na organização. Mayo e seus colaboradores apresentaram as bases da filosofia de administração denominada de Relações Humanas no Trabalho com ênfase em comunicação, participação, liderança, necessidades sociais e psicológicas.

O surgimento dessas bases foi considerado de reação à Administração Científica e apresentou mais possibilidade de atender às condições de desenvolvimento dos processos de comprometimento do trabalhador com a organização. Com esse período, surgiram novos nomes no elenco dos estudiosos do comportamento.

Embora os estudos de Abraham Maslow, em 1943, se voltassem para os motivos que impulsionam o ser humano a fazer, a realizar, não descortinaram os fatores que o fazem comprometer-se com o seu trabalho. Maslow ressaltou que as pessoas têm uma propensão natural para desenvolver seu potencial e buscar sua auto-realização. Sua contribuição ficou voltada para a motivação e criação da teoria dos motivos humanos com a conhecida hierarquia das necessidades. 
A defesa da importância da liberdade para que os funcionários possam realizar totalmente seu potencial criativo e produtivo veio com Douglas MacGregor em 1960, criador das Teorias X e $\mathrm{Y}$ sobre o comportamento humano, nas quais os pressupostos $\mathrm{X}$ estão baseados na necessidade de enfatizar o princípio da direção e controle por meio da autoridade e sobre os empregados, enquanto os pressupostos Y estão pautados no princípio da integração, no qual o compromisso do trabalhador, a engenhosidade, a imaginação e a criatividade podem ser utilizados para a solução de problemas organizacionais.

O potencial conflito entre a alternativa da participação e as visões autoritárias de gestão foi enfatizado por McGregor quando: iniciou o trabalho de desenvolvimento de equipes pelas crenças gerenciais, elucidando as motivações extrínseca e intrínseca por intermédio das teorias X e Y respectivamente; tomou por base os estudos de Maslow e inseriu a dinâmica seqüencial às necessidades humanas dentro do contexto organizacional. Os fatores $\mathrm{Y}$ estão relacionados às possibilidades de incremento do comprometimento dos trabalhadores.

Considerado um dos criadores da Gestalt, Kurt Lewin, em 1947, foi iniciador do treinamento de sensibilidade e dos estudos sobre a análise do Campo de Forças. Inspirado na perspectiva orientada para a investigação oriunda do pensamento de Lewin, Chris Argyris, desde 1961, é dedicado até hoje ao estudo da congruência sobre os objetivos do indivíduo e da organização e da visão da organização como responsável por obter o comprometimento do indivíduo. Argyris é responsável pela teoria sobre a racionalidade e intencionalidade humanas. As pesquisas de Argyris e de McGregor estão inspiradas em informações válidas, autonomia e comprometimento.

As conclusões da pesquisa de Frederick Herzberg (1959) levaram-no a duas categorias de necessidades humanas, independentes entre si e que influem no comportamento humano de modo distinto. A primeira está relacionada com o ambiente de trabalho, tem a função de impedir que os empregados fiquem insatisfeitos e é denominada de fatores higiênicos. A segunda está relacionada com a própria natureza da tarefa, promove a satisfação profissional e é denominada de fatores motivacionais.

As oportunidades de reconhecimento, realização, responsabilidade e crescimento foram visualizadas por Herzberg, tendo em comum com McGregor, a crença de que o relacionamento entre o trabalhador e seu trabalho será mais bem compreendido se os motivos e as necessidades do ser humano forem conhecidos. Os estudos de Herzberg estão voltados 
para os motivos que impulsionam o ser humano a se satisfazer pessoal e profissionalmente e ainda não se voltam para os fatores que o fariam comprometer-se com o seu trabalho. A importância do seu trabalho consiste no estímulo a novos estudos no campo da motivação no trabalho e satisfação do trabalhador no contexto organizacional.

Registre-se a importância dessa breve reapresentação de alguns nomes que marcaram as pesquisas com as respectivas contribuições para os termos desta pesquisa. Ressaltem-se, a seguir, as interfaces dos trabalhos de Maslow, MacGregor e Herzberg, as quais podem ser visualizadas na ilustração $\mathrm{N}^{0} 01$, destacando-se as possibilidades de envolvimento e engajamento vinculadas às visões de direção e controle, necessidades humanas que direcionam o comportamento e os fatores intrínsecos e extrínsecos que levam ao desconforto e ao conforto.

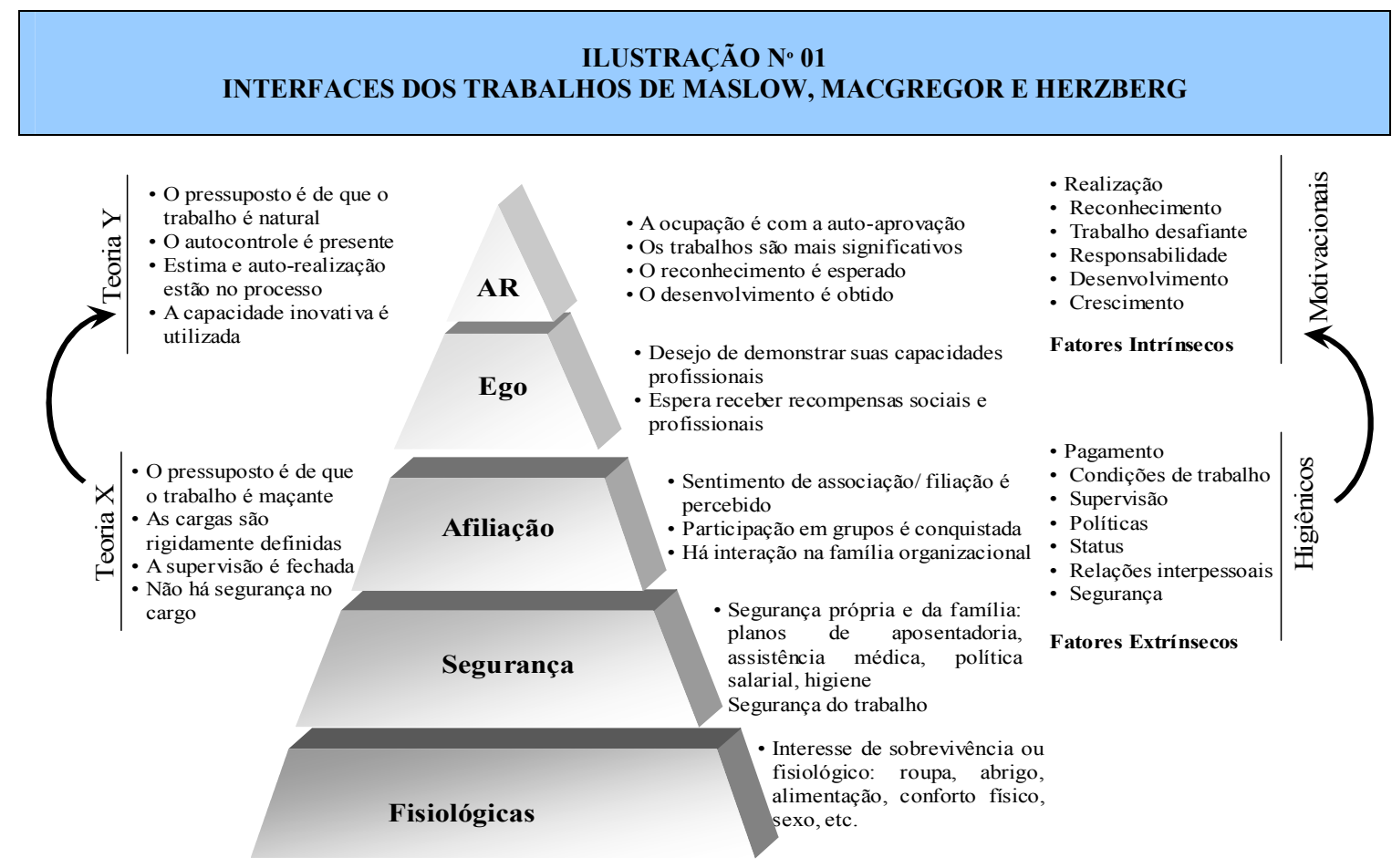

Douglas Mc Gregor - 1960 Visão Tradicional de Direção e Controle Integração do Indivíduo e das Metas da Empresa
Abraham H. Maslow - 1943

Hierarquia das Necessidades Humanas Simultâneas que Direcionam o Comportamento
Frederick Herzberg - 1950 Teoria dos Dois Fatores que Levam ao Desconforto e ao Conforto

Fonte: Elaborada por Leite, 2004.

A ilustração mostra que, a partir do nível da afiliação, na hierarquia das necessidades simultâneas, o indivíduo se torna mais fortalecido e consciente para fazer suas escolhas de 
envolver-se com trabalhos desafiantes que o levem a demonstrar o seu potencial inovativo, obter reconhecimento, exercer o autocontrole e conquistar a auto-realização.

As considerações acerca do comprometimento, tanto no trabalho de Maslow quanto no de Herzberg, podem ser, assim, resumidas: motivação e comprometimento não são mutuamente exclusivos, entretanto, o comprometimento é mais que um determinante pessoal à ação; satisfação e comprometimento não são mutuamente exclusivos, no entanto, o comprometimento é mais do que um estado psicológico de estar ou não satisfeito (CHANG, 2001). Enquanto Maslow aponta para as necessidades simultâneas que direcionam o comportamento humano e Herzberg elucida os fatores que levam ao desconforto e ao conforto do indivíduo, Chang chama a atenção para o que representa a condição necessária, mas não suficiente no estudo do comprometimento organizacional.

Assim, o comprometimento implica em mais do que uma decisão ou uma escolha. É a atuação de um indivíduo em busca das direções que emergem de dentro de si próprio, essa criação individual de uma verdade pessoal, por intermédio da ação, que constitui a essência do comprometimento. Implica em liberdade, responsabilidade, automotivação e autoconfiança.

\section{1. Diretriz teórica da pesquisa}

Dentre as abordagens ou correntes teóricas sobre comprometimento organizacional pesquisadas neste estudo, foram consideradas as vertentes de pesquisa que abordam aspectos estratégicos da gestão de pessoas, comportamentos relacionados à organização, motivações e orientações dos indivíduos e cultura organizacional, bem como a identificação com objetivos, metas e valores da organização. Serão, portanto, aqui consideradas, as abordagens ou correntes teóricas que podem contribuir com a pesquisa do enfoque comportamental do constructo comprometimento organizacional.

\section{2 Comportamento organizacional}

Os primeiros passos para o estudo do comportamento organizacional foram dados nos Estados Unidos, a partir de disciplinas dos cursos: Psicologia do Trabalho, Psicologia das Relações 
Industriais, Psicologia Social das Organizações, Psicologia das Organizações, Psicossociologia das Organizações e Engenharia de Fatores Humanos. Da sobreposição com Sociologia das Organizações e Teoria das Organizações foi enfatizada a interdisciplinaridade e, em 1990, foi criado pelo Instituto Superior de Psicologia o Mestrado em Comportamento Organizacional (PEREIRA, 2004).

Em sua evolução, o comportamento organizacional passou a receber contribuição da Psicologia no que tange a: aprendizagem, motivação, personalidade, emoções, percepção, treinamento, satisfação, tomada de decisão individual, eficácia de liderança, avaliação de desempenho, seleção de pessoal, planejamento do trabalho e stress profissional. A unidade de análise da Psicologia é o indivíduo, com vistas ao estudo do comportamento organizacional.

Da Sociologia, cuja primeira unidade de análise é o grupo, a contribuição diz respeito a: dinâmica dos grupos, trabalho em equipe, comunicação, poder, conflitos, e comportamento intergrupal. Ainda no âmbito da Sociologia, tomando-se como segunda unidade de análise o sistema organizacional, o estudo do comportamento organizacional recebe as seguintes contribuições: teoria da organização formal, tecnologia organizacional, mudança organizacional, e cultura organizacional.

Essas últimas contribuições estão vinculadas com a Psicologia Social, cuja unidade de análise é o grupo e suas contribuições são oferecidas no âmbito de: mudança comportamental, mudança de atitude, comunicação, processos e tomada de decisões grupais.

Oriundas da Antropologia, as contribuições voltadas para o grupo são os valores e as atitudes comparativos, e a análise multicultural, ao tempo em que as contribuições voltadas para o sistema organizacional são a cultura e o ambiente organizacionais. As Ciências Políticas, por sua vez, contribuem com o sistema organizacional no que tange ao conflito, às políticas intraorganizacionais e ao poder.

Mudanças na economia e na política mundial, nas últimas décadas, configuram um novo cenário, que conduz e, ao mesmo tempo, demanda o redesenho do mercado, do Estado e das demais instituições. As organizações parecem estar, cada vez mais, tendendo a voltar-se para a humanização e o desenvolvimento, imprimindo mais liberdade e consciência à sua força de trabalho. 
O estudo do comportamento organizacional tem incluído tanto a tomada de decisões com relação às situações organizacionais, como as percepções e sentimentos relacionados com essas situações. O comportamento organizacional traz em seu bojo a complexidade inerente ao ser humano, com as suas individualidades e idiossincrasias. As suas bases científicas que abrangem as ciências comportamentais, já aludidas, denotam complexidade e interdependência.

A complexidade e a interdependência, entre todos os níveis organizacionais, são função da unidade e da interdisciplinaridade. A organização, tomada como fonte de exploração econômica ou racionalidade, leva ao reducionismo. A liberdade de delegar possibilita ou limita. O poder, a organização e a ação são partes da ética nas relações de trabalho, que é alimentada pela coragem e pela maturidade. A ética, por sua vez, enseja os comportamentos.

O comportamento organizacional abrange, nessa sua complexidade, as dimensões enunciadas por Chanlat (1991-1993): cognitiva e da linguagem; espaço-temporal; psíquica e afetiva; simbólica; da alteridade; psicopatológica. Carece deixar de ser visto como um campo heterogêneo fadado a desenvolver-se isoladamente. Indica que é preciso iniciar a ser visto dentro das escolas, antes que o indivíduo passe a ocupar suas atividades, de modo efetivo, no mundo organizacional.

A efetividade organizacional, por sua vez, é determinada pelos seguintes aspectos: decisões sobre estratégias e projeto organizacional conjuntamente; discussões das questões abordadas na organização, dificilmente poderão ser equacionadas sem a discussão prévia do papel de cada indivíduo na história; o comportamento organizacional carece ser estudado numa perspectiva contingencial, intuitivamente lógica, atenta às diferenças organizacionais, às diferenças de valores, atitudes, necessidades e experiências, sem que possam ser esperados certeza e conhecimento absoluto; a complexidade e a interdependência, entre todos os níveis organizacionais, são função da unidade e da interdisciplinaridade; o poder, por si só, pode tornar possível a ação e ao mesmo tempo limitá-la.

Entretanto, por vezes, parece difusa para os executivos de topo das organizações a idéia de que precisam se ocupar com os seus próprios comportamentos no exercício do papel de gestores e com os comportamentos dos integrantes de suas equipes organizacionais. Por vezes, ainda, eles se dão conta das suas inabilidades e percebem que estão confusos com 
metas de produção, resultados financeiros e formas de gestão das pessoas. Handy (1978, p.13) dá o seguinte depoimento: "Comecei o estudo dos indivíduos em organizações esperando encontrar certeza e conhecimento absoluto nas ciências do comportamento. Imaginei que encontraria leis que, governando o comportamento dos indivíduos e das organizações, fossem tão certas e tão imutáveis quanto as leis das ciências físicas. Fiquei desapontado [...].”

Há uma ilusão que se revela muito comum nas tentativas da organização para controlar o comportamento humano. McGregor (1980, p. 21) afirma que "quando não alcançamos os resultados desejados tendemos a procurar a causa do processo por toda a parte, menos onde ela normalmente está: na escolha de métodos de controles inadequados."

A mudança da estratégia de controle para a estratégia de comprometimento, em que as equipes de trabalho possam refletir suas atitudes e demonstrar a eficácia dos seus comportamentos, parece ser o caminho mais indicado para a obtenção dos resultados estratégicos de gestão de pessoas.

Algumas organizações brasileiras estão tendendo a voltar seus olhares para o desenvolvimento de suas equipes. Entretanto, as ações de sensibilização e desenvolvimento dessa força de trabalho, em especial partindo dos gestores, ainda se apresentam incipientes para que o exercício da mudança do comportamento organizacional siga consistente, prodigalizando esforços para que as condições de liberdade, confiança e consciência sejam instauradas.

Do nível intelectual ao nível das emoções, há um longo caminho, principalmente quando se observa que as organizações estão na luta por sua sobrevivência, não obstante o vislumbre trazido pelas pesquisas de Fischer (2002), o qual salienta a importância que o comportamento humano vem assumindo no âmbito das organizações e o conseqüente ganho de espaço na teoria organizacional.

Torna-se relevante, a partir desse ponto, elucidar conceitualmente o que está sendo considerado como comportamento nesta pesquisa. Na base filosófica desenvolvida por Abbagnano (2003, p.156), comportamento é "toda resposta de um organismo vivo a estímulos, que seja: primeiro objetivamente observável por um meio qualquer; segundo uniforme.” Esse conceito assumiu, inicialmente, a ênfase da exigência da psicologia e, em geral, qualquer consideração científica das atividades humanas que possam ter por objeto 
elementos observáveis objetivamente. Para o autor, o comportamento especificamente humano é oriundo da atitude e inclui, portanto, elementos antecipatórios e normativos.

O primeiro ponto mostrado pela base filosófica encontra eco em autores como: Bernardes (1988, p. 76) quando define que "comportamento é todo tipo de ação observável de uma pessoa"; Valença $(1997$, p. 261) ao definir que "ação são comportamentos humanos com significados inter-relacionais ou sociais próprios"; Lorsch e Morse (1974, p. 11) quando salientam que "como uma organização, um indivíduo pode ser visualizado como um sistema de partes inter-relacionadas que interagem com seu ambiente"; Pereira (2004, p. 39) ao afirmar que “comportamento é, na formulação geral, toda ação observável num sistema aberto"; Leavitt (1964, p. 12) quando indica três pressupostos inter-relacionados com o comportamento humano quais sejam: "[...] O comportamento é causado por estímulos internos ou externos [...] $\mathrm{O}$ comportamento é motivado, ou seja, há uma finalidade em todo o comportamento humano [...] O comportamento é orientado para as metas [...].” Todos esses estudiosos têm como pontos comuns a ação e a inter-relação humanas passíveis de observação.

No que tange ao comportamento especificamente humano como sendo oriundo da atitude tendo inclusos elementos antecipatórios e normativos, Kanaane (1995) salienta que normalmente comportamento e atitude são confundidos e ditos sinônimos, gerando, como conseqüências, discrepâncias fundamentais para a compreensão da conduta da pessoa. Segundo o autor, comportamento é reação e atitude é a tendência à reação. Nesse sentido, Abbagnano e Kanaane estão de acordo. O estudo do comportamento humano corresponde à compreensão das ações expressas pelo indivíduo no contexto social. Essas ações poderão ou não corresponder às atitudes previamente determinadas. Para eles, provavelmente em última instância, o comportamento do indivíduo representa sua capacidade de adaptar-se ao meio social circundante.

Nessa linha de raciocínio, até determinado ponto o comportamento humano e a experiência consciente da pessoa podem ser descritos, previstos, influenciados e modificados. Para tanto, necessitam de um motivo para a ação de mudança de comportamento, a partir das crenças fundamentais do indivíduo que só pode receber influência com base na observação e no feedback. Murray, apud Bernardes (1988, p. 77) associa o comportamento com o motivo humano e diz que "motivo é um impulso interno que dá início, dirige e integra o comportamento de um indivíduo." 
Tal impulso pode contar com a ajuda de apoios externos. O feedback pode ser caracterizado como um apoio externo e genuíno para a mudança. De acordo com Rogers (1983, p. 41), os seres humanos carecem desse apoio genuíno, de outros seres humanos, para que possam ter clareza do que se passa dentro de si mesmos. O autor afirma que "[...] A chave para entender seu comportamento é a luta em que se empenham para crescer e ser, utilizando-se dos recursos disponíveis." Com base no impulso interno e no apoio recebido, a mudança de comportamento pode vir então a ocorrer. Merece ser destacado o fato de que os seres humanos são objeto e sujeito de sua ciência e compõem a própria história.

Uma compilação de conceitos e idéias sobre o tema pode trazer mais luz à compreensão do comportamento humano nas organizações, no que tange à relação entre gestores e integrantes de equipes organizacionais.

Os gestos, as ações, os sentimentos e os pensamentos precisam ser compreendidos e interpretados adequadamente pelos gestores. Casado (2002b, p. 257) afirma que: "o papel do gestor deverá ser sempre o de identificar os norteadores de comportamento de seus subordinados, assumindo a natureza intrínseca e individual da motivação de modo a gerir a direção da energia que naturalmente se encontra dentro de cada um no sentido compatível com os objetivos da organização e com o crescimento de cada integrante de seu grupo de trabalho."

Não basta que o gestor identifique uma visão coerente e atraente da organização. Faz-se necessário comunicá-la na cultura organizacional. Essa visão precisa ser transmitida por meio de persuasão e inspiração, em lugar de edição ou coerção. Uma vez transmitida, a visão precisa ser reforçada pelas decisões e ações de apoio do gestor.

Mudanças precisam ser feitas na estrutura organizacional e processos gerenciais consistentes com os valores contidos nessa visão. Essas mudanças, por sua vez, deverão estar em linha com os norteadores de comportamento identificados, de modo a privilegiar o crescimento de cada indivíduo.

Tal base de apoio encontra-se assentada entre as competências de um gestor. Dentre essas competências, ressalta-se a sua disposição, como ator social, de contribuir para a transformação da organização, pela transformação das próprias atitudes que facilitarão a mudança de comportamento dos seus integrantes. 
Esse raciocínio é reforçado por Limongi-França (2002, p. 267) em seu estudo sobre a evolução do processo de transformação de grupos, equipes e times de trabalho: "o comportamento individual passou a ser focado na valorização das ações em equipe e formação de times." A mesma autora, (2006, p. 3) além de definir o comportamento organizacional como "o estudo de ações, atitudes e expectativas humanas dentro do ambiente de trabalho", mostra a aplicação na geração das práticas e modelos de gestão de pessoas, no que tange às questões psicológicas, sociais, biológicas e organizacionais.

No que diz respeito a essas questões, Chanlat (1991, p. 94) fala do espaço organizacional manifestado por intermédio da interação social com o comportamento territorial do indivíduo, o que demonstra, ao mesmo tempo, o ser singular e genérico que ele é.

Para quem trabalha, o espaço que lhe é destinado é progressivamente investido como um local pessoal. Através de múltiplas atitudes, o indivíduo traduz uma tendência fundamental a habitar o lugar no qual ele está, familiarizando-se com ele e transformando-o. Assim, ele cria em seu ambiente, procedimentos que lhe facilitam as tarefas, reage à intrusão dos outros por uma defesa característica de seu território, cria para si mesmo sistemas de adaptação e dominação que traduzem a pregnância de seu espaço como ponto de ancoragem [...] o espaço é o objeto de socialização: é através do grupo que se faz a iniciação num lugar novo, de maneira que o processo de integração social e a fase de aprendizagem do território profissional constituem dois pólos dessa dinâmica social/organizacional.

Diante do que é exposto por esse autor, depreende-se que o comportamento organizacional segue os princípios do comportamento humano em sua singularidade.

Por outro lado, na abordagem de DuBrin (1974, pp. 14; 241), existem os fatores internos e externos que influenciam o comportamento das pessoas na organização, bem como os fatores potenciais que influenciam o indivíduo dentro dela.

O comportamento das pessoas em uma organização depende de fatores internos como capacidade de aprendizagem, motivação, percepção, atitudes, emoções, frustrações e valores e de fatores externos como tensão, sistema de recompensas, grau de confiança, coesão grupal, nível de ruído, fatores sociais e políticas [...] O indivíduo na organização é influenciado por fatores potenciais como condições ambientais, estados de energia interna, pressões do superior, influências dos colegas, sistemas pessoais, mudanças na tecnologia, demandas da família e programas de treinamento e desenvolvimento.

Tanto os fatores internos quanto os externos se vinculam à complexidade da natureza humana, no sentido da apropriação para receber a influência dos fatores potenciais. Os fatores enumerados por DuBrin relembram os estudos de McGregor, Maslow e Herzberg. 
Partindo-se da constituição, diz-se que o comportamento organizacional é composto por três elementos críticos inter-relacionados, quais sejam: tarefas, indivíduos e grupos (NADLER, HACKMAN e LAWLER III, 1983).

De acordo com Davis (1983, p. 3), o "comportamento organizacional é o estudo e a aplicação de conhecimentos relativos à maneira com que as pessoas atuam dentro das organizações." Dentre esses conhecimentos, está a natureza humana e sua complexidade.

A complexidade da natureza do homem estudada por Thompson e van Houten (1975, p. 30) é enfocada sob três aspectos: "o homem como um ser transacional [...] proativo [...] o homem como um comportamento dirigido para um objetivo [...] o homem como um modelo de sistema aberto, dirigido para objetivos, interdependentemente com o meio físico e social [...]." Tais aspectos estão inseridos em um conjunto de necessidades humanas que é acionado de modo peculiar por cada indivíduo.

Em estudo desenvolvido por Kanaane (1995, p. 61) é concluído que "comportamento é um conjunto de operações materiais e simbólicas, entendido como um processo dialético e significativo em permanente interação." Para esse autor, o aspecto dialético do comportamento possibilita que ele seja compreendido como um sistema de múltiplas interações e, as operações, oriundas do âmago das necessidades humanas, permitindo o surgimento de novas instâncias de comportamentos.

Autores como Schermerhorn Jr., Hunt e Osborn (2000, p. 29) assumem que o “comportamento organizacional é um corpo interdisciplinar de conhecimento com forte ligação com as ciências comportamentais da psicologia, sociologia e antropologia; bem como com as ciências sociais tais como economia e sociologia."

Segundo Wagner III e Hollenbeck (2003, p. 6), “comportamento organizacional é um campo de estudo voltado a prever, explicar, compreender e modificar o comportamento humano no contexto das empresas. Enfoca comportamentos observáveis. Estuda o comportamento das pessoas tanto como indivíduos quanto como membros de unidades sociais menores. Busca facilitar o entendimento de processos grupais e organizacionais." 
Por outro lado, a pesquisa de Soto (2002, p. 46) mostra que "a emoção é o elo de grande importância na cadeia causal do comportamento humano e assume papel significativo no processo motivacional."

Essa abordagem é reforçada por Rodrigues (2001), quando chama a atenção para o estudo do comportamento no trabalho, capaz de privilegiar o pensar voltado para a intersecção entre a espiritualidade, a experiência sensível cotidiana, a intelectualidade e os diversos jogos emocionais existentes no contexto organizacional. Dentre as abordagens compiladas, as duas últimas são respaldadas pelos estudos acerca da subjetividade de Davel e Vergara (2001).

A proposta de entendimento sobre esse ponto, elaborada por Casado (2007, p. 214), acolhe a perspectiva do ser humano não só como componente, mas também como alvo do processo. Ela concebe o comportamento organizacional "como o conjunto de conhecimentos sobre o homem e sua interação com as demais pessoas, com seu trabalho e com outros aspectos da vida organizacional, que ajudam no entendimento das questões humanas e que concorrem para o atendimento dos objetivos organizacionais e para o desenvolvimento pleno do potencial humano."

\section{3 Comprometimento organizacional}

Esse é um termo considerado chave, a ser fundamentado no escopo desta pesquisa. Com essa parte da fundamentação, pretende-se consubstanciar e consolidar a pesquisa de campo, com a investigação apoiada em estudos de casos, privilegiando-se as recomendações que emergem da literatura como imprescindíveis à superação de problemas encontrados em estudos sobre comprometimento, a fim de que variáveis importantes em sua determinação possam ser investigadas conforme recomendado por Bastos (1994 a).

Por inquietação e opção pessoal da autora desta pesquisa, esta parte envolve a busca dos sentidos filosófico e psicológico do comprometimento, com vistas a privilegiar a contribuição para o enfoque comportamental do constructo comprometimento organizacional. Aqui, a base escolhida para o sentido filosófico foi, fundamentalmente, buscada em Abbagnano (2003), evitando-se reiteradas referências. 
Recorrendo-se à filosofia existencialista, depreende-se que o comprometimento pode assumir sentido de compromisso, decisão ou escolha. A idéia do envolvimento que antecede ao ato de decidir ou escolher foi trazida por Heidegger. Sartre viu, no engajamento, o nascimento do projeto fundamental que é a expressão da liberdade humana e disse que o ser humano é a solução do problema e faz existir essa solução com o engajamento, somente com o qual é capaz de atingir a solução e vivê-la.

O pensamento desses filósofos é reforçado pela psicologia, na qual se pode apreender que, o indivíduo que se considera a si mesmo e à sua situação, claramente, e, livremente, assume a responsabilidade por seu próprio ser e por tal situação, revela-se, com nitidez, em importantes aspectos do seu comportamento. Sob essas condições, o comprometimento com os propósitos e o significado da vida é um dos mais importantes elementos de mudança de comportamento. (ROGERS, 1977).

Em sentido psicológico, esse autor entende que é fácil dar ao comprometimento significação demasiadamente superficial, indicando que a pessoa, por uma simples escolha consciente, se comprometeu num ou noutro curso de ação. Ele atribui significado bem mais profundo e afirma que o comprometimento pessoal é uma direção organísmica total, envolvendo não só o espírito consciente, mas, por igual, a direção de todo o organismo.

Nesse sentido em que é descrito pelo autor, o comprometimento é uma realização. É aquela espécie de direção, plena de propósito e de significado, que só gradualmente é empreendida pela pessoa que, intimamente, vive em relação com o que é a sua própria experiência - um relacionamento no qual suas tendências inconscientes são tão respeitadas quanto suas opções conscientes. É o tipo de comprometimento, no sentido do qual o autor crê que os indivíduos podem se encaminhar.

Meyer e Herscovitch, apud Bastos, Siqueira, Medeiros e Menezes (2008, p. 50) afirmam que "Todas as definições de comprometimento fazem, em geral, referência ao fato de que comprometimento é: a) uma força que estabiliza e coage; b) dá direção ao comportamento (por exemplo, restringe liberdade, liga a pessoa a um curso de ação).”

Os autores Bastos, Siqueira, Medeiros e Menezes (2008) salientam que as diferenças entre as definições estão relacionadas aos detalhes relativos à natureza ou à origem de tal força que 
direcionam o comportamento. Eles relembram a vertente que destaca a necessidade de tratar o comprometimento a partir dos indicadores comportamentais ou de processos que vinculam o indivíduo a um curso específico de ação.

A definição de Teixeira (1994, p. 268) enfoca, também, “o comprometimento como capaz de propiciar uma melhor compreensão da natureza e dos processos psicológicos pelos quais as pessoas escolhem identificar-se com objetivos em seu ambiente e atribuir-lhe sentido."

Via compreensão da natureza e dos processos psicológicos, o homem obtém maior êxito em tal comprometimento, quando atua como indivíduo integrado, total, unificado. E, quanto mais atua dessa forma total, maior confiança tem nas direções que, inconscientemente, escolhe. A confiança na sua experiência tende a crescer, mesmo quando só possui relances parciais na sua consciência.

Depare-se, nesse ponto, com visões possivelmente divergentes e contraditórias. De um lado, forças da vida atual sustentam a opinião de que o homem não é livre, é controlado, e expressões como propósito, escolha, comprometimento, não possuem teor significativo e, o homem, nada mais é do que um objeto que pode ser amplamente compreendido e controlado.

Opondo-se a essa visão do homem destituído de liberdade, existe a evidência oriunda da vida subjetiva, assim como da pesquisa objetiva, de que a liberdade e a responsabilidade pessoais têm significado crucial e de que a autocompreensão e a opção responsável produzem diferença marcante e mensurável no comportamento do indivíduo.

Em tal contexto, o significado do comprometimento é a emergente e mutável direção total do indivíduo, baseada num relacionamento íntimo e receptivo entre a pessoa e todas as tendências da sua vida, conscientes e inconscientes. Parte verdadeiramente crucial da sua existência é a descoberta do seu próprio compromisso significante de viver empenhando todo o seu ser. Voltando a atenção para o que disse Polanyi (1958) apud Abbagnano (op. cit.), filósofo da ciência, o qual crê que o comprometimento pessoal profundo é a única base sobre a qual pode a ciência manter-se, compreende-se que pela ciência, sob todos os seus aspectos, perpassa o comprometimento pessoal, disciplinado. Esse filósofo sustenta que toda tentativa de estabelecer um divórcio entre a ciência e a pessoa é absolutamente irrealista. A seu ver, o positivismo lógico e toda a estrutura da ciência não podem fazer escapar o fato de que todo conhecimento é incerto, 
comporta risco e só é captado e compreendido por meio de um profundo comprometimento pessoal numa pesquisa disciplinada.

Lidar com essas visões, possivelmente divergentes e contraditórias da vida subjetiva e da pesquisa objetiva para investigar o comprometimento no trabalho como um conceito atitudinal, incluindo tendências cognitivas e comportamentais, ainda em construção, impreciso, ambíguo e redundante, de acordo com a literatura pesquisada, é o compromisso pessoal da autora desta pesquisa. Pelo fato de ser considerado como um constructo em construção, no qual a exigência de articulações de uma definição rigorosa adquire importância vital, busca-se, nesta pesquisa, investigar a contribuição da filosofia e da psicologia para possível refinamento dos conceitos nele envolvidos.

Envolvimento, compromisso, engajamento, decisão e escolha fazem parte do repertório de muitos estudiosos do comprometimento organizacional, como pode ser visto em Salancick apud Mowday, Porter e Steers (1982, pp. 24-26) que, enfatizando a perspectiva comportamental, define comprometimento como "um estado de ser em que um indivíduo torna-se levado por suas ações e através dessas ações acredita que elas sustentam as atividades de seu próprio envolvimento." Nessa perspectiva, a semelhança entre o que é dito por Heidegger, Rogers e Salancik consiste na natureza do ser e na ação do envolvimento.

Acerca desse assunto, o estudo de Robbins (2002 - 2005) abarca a participação, o envolvimento e o comprometimento como três atitudes crescentes. Desse modo, o autor considera que um indivíduo só pode envolver-se em seu trabalho quando participa ativamente dele, identifica-se psicologicamente com ele e considera o seu desempenho como algo valioso para si. Da mesma forma, o indivíduo só está apto a comprometer-se quando se identifica com uma organização e com os seus objetivos, desejando manter-se parte dessa organização.

Também no campo da filosofia, o comprometimento é tratado como compromisso e definido como "escolha fundamental que dirija a conduta ou o procedimento de investigação num campo qualquer" de acordo com Abbagnano (2003, p. 160). Segundo o autor, na filosofia existencialista, comprometimento foi usado para indicar $o$ fato de que qualquer esclarecimento que o homem possa obter sobre as determinações da existência é um compromisso, uma decisão ou uma escolha com tal determinação. Ainda em sua obra, a 
participação é tida como a relação entre as coisas sensíveis e as idéias, enquanto o envolvimento é tomado como uma implicação, à luz de Platão e Spinoza.

Para Menegon e Casado (2006, p. 134), o comprometimento tem seu significado associado à responsabilidade:

Comprometer-se significa assumir responsabilidade sobre algo. Na medida em que o indivíduo deixa de ser responsável por aquilo que assumiu, ele pode contribuir com uma piora dos índices de desempenho organizacional e dificultar a consecução das estratégias organizacionais, entre outras coisas; isso ocorre principalmente se o indivíduo que perder o comprometimento tiver uma posição estratégica.

A partir desse ponto, será tratado o constructo comprometimento organizacional, com base nos pesquisadores que vêm empreendendo esforço em prol da minimização dos efeitos da imprecisão, da ambigüidade e redundância que ainda envolvem a sua construção.

A determinação e a escolha são enfocadas por Borges-Andrade, (1993, p. 50) quando se refere ao comprometimento organizacional como o "grau em que os empregados se identificam com suas organizações empregadoras e estão dispostos a defendê-las e nelas permanecerem." Tal identificação, por sua vez, incrementa a confiança nas direções que, inconscientemente, o indivíduo escolhe. Desse modo, a confiança na sua experiência tende a continuar a crescer, mesmo quando só possui relances parciais na sua consciência.

Envolvimento, compromisso, engajamento, decisão e escolha fazem parte, também, do pensamento de Porter e Smith, apud Mowday, Steers e Porter (1979, p. 225) quando definem o comprometimento dentro de uma perspectiva atitudinal ativa:

Comprometimento é uma relação forte entre um indivíduo identificado com e envolvido numa organização em particular, e pode ser caracterizado por pelo menos três fatores: estar disposto em exercer um esforço considerável em benefício da organização; uma forte crença e a aceitação dos objetivos e valores da organização; um forte desejo de se manter como membro da organização.

Essa definição opõe-se à visão do homem destituído de liberdade. Reforça a idéia de que liberdade e responsabilidade pessoais têm significado relevante para que a opção responsável venha a produzir diferença significativa no comportamento do indivíduo. 
Quando Bastos (1993, pp. 58-63) afirma que "o comprometimento é feito para manter a consistência de comportamentos e atitudes" retrata o que foi dito por Sartre a respeito do ser humano ser a solução do problema e fazer existir essa solução com o engajamento. Para o autor "os problemas conceituais que cercam a definição e os enquadres teóricos de comprometimento organizacional associam-se aos problemas metodológicos detectáveis nesta tradição de pesquisa, fazendo com que seus resultados não correspondam às expectativas e à quantidade de esforço já investido pelos pesquisadores."

Um dos autores seminais sobre os estudos do comprometimento comportamental, vinculado com ações, Salancik (1977) aponta três elementos fundamentais para gerar comprometimento: a volição, a visibilidade e a irreversibilidade das ações. Ele enfatiza que esses elementos contêm sentimento e responsabilidade com o curso da ação escolhido. Em linha com esse autor, encontram-se as abordagens dos filósofos e da psicologia, mais especificamente da psicologia Rogeriana. Sob as condições de liberdade e responsabilidade por eles ressaltadas e pelo sentido trazido por Salancik, o comprometimento passa a ser mais que um compromisso, decisão ou escolha, podendo assumir um sentido de realização, pleno de propósito e significado.

Diversos autores reconhecem e apontam a existência de várias definições e enquadres teóricos para o comprometimento organizacional. Mowday, Porter e Steers (1982, p. 21) mencionam dez diferentes definições acerca do comprometimento organizacional e afirmam: "dessas definições fica claro que não existe um verdadeiro consenso com relação à definição do constructo." Borges-Andrade; Afanasief; Silva (1989) afirmam ser o comprometimento organizacional um constructo novo na literatura internacional e sem registros de pesquisas no Brasil. BorgesAndrade; Cameschi; Silva (1989) referem-se ao estudo do comprometimento organizacional como escasso no Brasil. Bastos (1994a) ressalta a redundância, a ambigüidade e a imprecisão dos conceitos existentes nas definições do comprometimento organizacional. Meyer e Allen (1997) afirmam que não há consenso com relação à definição de comprometimento.

Segundo Popper e Lipshitz (1992) apud Bastos (1994 a, p. 41), assim fica justificada a inexistência de um consenso na literatura sobre comprometimento organizacional: "À diversidade de definições, com raízes em distintas disciplinas científicas que contribuem para a compreensão do comprometimento organizacional, associam-se operacionalizações diversas do constructo, o que constitui uma fonte adicional e importante de fragmentação da área." 
A investigação do Comprometimento Organizacional é oriunda de três fontes teóricas: Sociologia, Teorias Organizacionais e Psicologia Social, conforme mostrado no quadro $\mathrm{n}^{\mathrm{o}} 01$.

\begin{tabular}{|c|c|c|c|}
\hline \multicolumn{4}{|c|}{$\begin{array}{c}\text { QUADRO No } \mathbf{N}^{\circ} 01 \\
\text { FONTES TEÓRICAS E ENFOQUES }\end{array}$} \\
\hline $\begin{array}{c}\text { Marcos } \\
\text { Importantes }\end{array}$ & Sociologia & Teorias Organizacionais & Psicologia Social \\
\hline 1938 & & Barnard (enfoque instrumental) & \\
\hline 1940 & & & Lewin (enfoque comportamental) \\
\hline 1957 & & & $\begin{array}{l}\text { Festinger } \\
\text { (enfoque comportamental) }\end{array}$ \\
\hline 1958 & & $\begin{array}{l}\text { March, Simon } \\
\text { (enfoque instrumental) }\end{array}$ & \\
\hline 1960 & Becker (enfoque instrumental) & & \\
\hline 1961 & & Etzione (enfoque afetivo) & \\
\hline 1968 & Kanter (enfoque instrumental) & Kanter (enfoque afetivo) & \\
\hline 1969 & $\begin{array}{l}\text { Ritzer, Trice } \\
\text { (enfoque instrumental) }\end{array}$ & & \\
\hline 1971 & & & $\begin{array}{l}\text { Kiesler } \\
\text { (enfoque comportamental) }\end{array}$ \\
\hline 1973 & $\begin{array}{l}\text { Alluto, Hrebeniak, Allonso } \\
\text { (enfoque instrumental) }\end{array}$ & & \\
\hline 1974 & & Buchanan, (enfoque afetivo) & \\
\hline 1975 & & & $\begin{array}{l}\text { Ajzen, Fishbein } \\
\text { (enfoque normativo) }\end{array}$ \\
\hline 1977 & & & $\begin{array}{l}\text { Salancik } \\
\text { (enfoque comportamental) }\end{array}$ \\
\hline 1979 & $\begin{array}{l}\text { Edwards (autoridade no con- } \\
\text { texto comportamental do tra- } \\
\text { balho) }\end{array}$ & & \\
\hline 1980 & & & $\begin{array}{l}\text { Staw } \\
\text { (enfoque comportamental) }\end{array}$ \\
\hline $1980-1981$ & & & $\begin{array}{l}\text { Pfeffer-Lawler, O'Reilly- } \\
\text { Caldwell } \\
\text { (enfoque comportamental) }\end{array}$ \\
\hline 1982 & & $\begin{array}{l}\text { Mowday, Steers, Porter } \\
\text { (enfoque afetivo ou atitudinal) } \\
\text { Weiner, Vardi } \\
\text { (enfoque normativo) }\end{array}$ & \\
\hline 1983 & $\begin{array}{l}\text { Buraway } \\
\text { (autoridade no contexto com- } \\
\text { portamental do trabalho) }\end{array}$ & & \\
\hline 1984 & & $\begin{array}{l}\text { Meyer, Allen } \\
\text { (enfoque instrumental) }\end{array}$ & \\
\hline 1986 & $\begin{array}{l}\text { Halaby } \\
\text { (autoridade no contexto com- } \\
\text { portamental do trabalho) }\end{array}$ & & \\
\hline 1994 & & $\begin{array}{l}\text { Bastos } \\
\text { (enfoque afetivo) }\end{array}$ & \\
\hline 2000 & & $\begin{array}{l}\text { Thévenet } \\
\text { (enfoque afetivo) }\end{array}$ & \\
\hline
\end{tabular}

Tal investigação elucida os enfoques instrumental, afetivo, normativo e comportamental dessas abordagens conceituais. O enfoque de três dimensões do comprometimento (afetivo, 
instrumental e normativo) é reafirmado por Allen e Meyer (1990, p. 3) que enfatizam: "empregados com um forte comprometimento afetivo permanecem na organização porque eles querem, aqueles com comprometimento instrumental permanecem porque eles precisam e aqueles com comprometimento normativo permanecem porque eles sentem que são obrigados."

Meyer e Allen (1997) ressaltam que diversas pesquisas têm demonstrado que, empregados que apresentam um forte comprometimento afetivo obtêm um desempenho melhor em relação aos empregados que apresentam um fraco comprometimento.

Pode-se pressupor que, mesmo em nível inconsciente, as pessoas poderão tender a fazer suas escolhas em todos os três enfoques.

É, ainda incipiente, a compreensão das variáveis pessoais como parte do conceito de comprometimento. Gouldner (1960, pp. 471-472) aborda duas dimensões para o comprometimento com aspectos distintos de integração e introjeção, em que o comprometimento na dimensão da integração "é o grau em que um indivíduo é ativo e se sente parte, em vários níveis, de uma organização em particular” e, na dimensão da introjeção, comprometimento "é o grau em que a própria imagem de um indivíduo inclui uma variedade de características e valores organizacionais aprovados.” $\mathrm{Na}$ abordagem desse autor, está implícita a insinuação dessas variáveis pessoais, bem como das categorias nas quais elas podem estar inseridas.

Uma outra pesquisa, nessa direção, é a análise de cento e vinte quatro estudos publicados entre 1967 e 1987 a qual mostra que Mathieu e Zajac (1990) dividem as variáveis utilizadas nas pesquisas em três categorias: antecedentes, correlatos e conseqüentes. Na categoria dos antecedentes, estão as características pessoais, do trabalho e organizacionais, relações com grupo e com líder, status da função, dimensões da estrutura organizacional. A categoria dos correlatos contém motivação, satisfação, stress, envolvimento com o trabalho. A categoria dos conseqüentes abrange performance, alternativas, intenções (permanecer na organização ou procurar nova organização), comparecimento, pontualidade, turnover.

Esse trabalho de análise explicita melhor as variáveis humanas do comprometimento, mas não explicam o porquê da inserção delas no conceito. São relativamente poucos os trabalhos 
teóricos que ajudam a explicar porque as variáveis pessoais deveriam ser relacionadas ao comprometimento. Por intermédio desse estudo, esses autores afirmam que muitos pesquisadores têm incluído variáveis pessoais no estudo do comprometimento mais como uma descrição estatística do que como varáveis exploratórias.

A partir deste ponto, procurar-se-à entender, enfatizar e buscar contribuir com a visão do comprometimento organizacional como o nível do vínculo psicológico do indivíduo com a organização, conforme é apresentada por Meyer e Allen (1997).

Vale aqui salientar que, as buscas no âmbito da filosofia, em todos os três enfoques, continuarão assentadas nas bases de Abbagnano (2003), cuja obra será doravante referenciada como (op. cit.) Relembre-se que, na definição do constructo comprometimento, Meyer e Allen conceitualizam os três enfoques da seguinte forma:

\section{Enfoque 1: No comprometimento afetivo, os trabalhadores têm apego, afeto pela organização.}

Nesse sentido em que é descrito, o comprometimento pode ser considerado uma realização na qual os indivíduos podem se encaminhar.

Pesquisando-se na filosofia o significado do adjetivo afetivo, observa-se que ele não se vincula ao da palavra afeto, já que designa, em geral, tudo o que se refere à esfera das emoções. As emoções podem referir-se tanto a pessoas quanto a coisas, fatos ou situações. $\mathrm{O}$ que comumente se chama de necessidade de afeto "é a necessidade de ser compreendido, assistido, ajudado nas dificuldades, seguido com o olhar benévolo e confiante. Nesse sentido, o afeto não é senão uma das formas de amor."

As pesquisas organizacionais não apontam para essa direção, entretanto. Mais adiante, se diz que os afetos constituem a classe restrita de emoções que acompanham algumas relações interpessoais, a exemplo das relações entre pais e filhos, entre amigos, entre parentes, limitando-se à tonalidade indicada pelo adjetivo afetuoso e que, por essa razão, exclui o caráter exclusivista e dominante da paixão. "Em geral, entende-se por emoção qualquer estado, movimento ou condição que provoque no animal ou no homem a percepção do valor 
(alcance ou importância) que determinada situação tem para sua vida, suas necessidades, seus interesses." (op. cit, pp. 21-311).

Em estudo desenvolvido por Bion (1961, p. 60), é enfatizado que "o estado emocional existe primeiro e que o pressuposto decorre daí." Em quase todas as suas obras, nas quais simplicidade e complexidade sempre foram honradas, Bion trata emoção como similar a sentimento. Deixa claro que aprendizagem registra, única e abundantemente, emoção, enquanto elementos registram unicamente sentimento. Integra elementos muito variados da filosofia e da matemática às suas experiências psicanalíticas.

Por outro lado, pesquisa realizada por Damásio (2004, pp. 189, 191-192) conclui que

[...] a emoção e o sentimento desempenham papel principal no comportamento social e, por extensão, no comportamento ético [...] Quando os sentimentos se tornam conhecidos para o self do organismo que os possui, melhoram e ampliam o processo de governar a vida [...] Os sentimentos não são supérfluos [...] Trata-se, sim, de descobrir as circunstâncias nas quais os sentimentos podem de fato ser um árbitro, e combinar inteligentemente circunstâncias e sentimentos de forma que possam guiar o comportamento humano.

O autor não faz, como Bion, a distinção entre emoção e sentimento, mas demonstra que ambos têm significados relevantes para o comportamento humano.

Esse raciocínio é respaldado pela filosofia, na qual Platão e Aristóteles afirmaram que as emoções têm significados porque elas têm uma função na economia da existência humana no mundo.

Entretanto, para os estóicos, as emoções não têm significado nem função. O pressuposto da análise estóica é a tese da perfeita racionalidade humana. Bernardes (1988, p. 68) elucidou uma visão dos sentimentos que está em linha com o que ainda é observado na atualidade das organizações e que, corroborando os filósofos, têm uma função na existência humana dentro do contexto organizacional. "Sentimentos para nós representa a manifestação das emoções decorrentes da estrutura de tarefas, normas, posições, crenças e valores.”

O raciocínio de Bernardes é ampliado por Robbins, (2003, p. 163) que afirma:

As emoções são partes de nossas vidas. Ou seja, não somos só raciocínio, sentimos também! Mas o campo da gestão tem sido culpado há muito tempo por tratar funcionários como se eles 
fossem entes desprovidos de emoções. Todo comportamento no trabalho é presumido como se fosse totalmente racional. Embora esse esforço contribua para uma análise mais simples do comportamento no trabalho, é possível que ele gere avaliações altamente imprecisas e não realistas.

O valor das emoções, por meio dos variados significados trazidos pela filosofia e pela psicologia, é destacado pelos significados que trazem à tona a indivisibilidade da natureza humana. Tal indivisibilidade parece permear a essência da convivência nas organizações, mas os sentimentos ainda não são explicitamente tratados em seu cotidiano. Não obstante alguns autores considerarem que as pesquisas de comprometimento estiveram vinculadas ao aspecto afetivo, não fica claro o conceito de afetivo utilizado por eles, conforme observado nas afirmações:

Comprometimento pode ser visto como um partido ou como um apego afetivo aos objetivos e valores de uma organização (BUCHANAN, 1974, p. 533);

Existe uma correlação positiva entre o comprometimento afetivo e a performance no trabalho e uma relação negativa entre o comprometimento instrumental e a performance no trabalho (MEYER, PAUNONEM, GELLATHY, GOFFIN e JACKSON, 1989, pp. 153-154);

O comprometimento afetivo e em menor extensão o comprometimento normativo poderiam ser positivamente relacionados com a performance no trabalho, entretanto o comprometimento instrumental não tem relação ou está negativamente relacionado com a performance no trabalho (MEYER, ALLEN e SMITH 1993, p. 539);

Depois de um longo período em que a pesquisa do comprometimento foi focalizada quase que exclusivamente num apego afetivo às organizações, uma nova perspectiva baseada no modelo de múltiplos componentes está emergindo (SOMERS, 1995, p. 54).

Depreende-se a necessidade de compreender o trabalho desses autores, tanto com relação às emoções quanto com relação à indivisibilidade da natureza humana. Considerando-se a base filosófica e a definição do enfoque afetivo do constructo, pode-se deduzir o espaço para investigar mais o significado dado pelos autores ao adjetivo afetivo.

Enfoque 2: No comprometimento instrumental, os trabalhadores agem movidos por necessidade e escassez de alternativas imediatas de emprego e não necessariamente por quererem ou estarem dispostos a se esforçar em prol da organização.

Essa abordagem está em linha com as forças da vida atual, em que há a sustentação da opinião acerca da falta da liberdade do homem. 
De acordo com Dewey, "como termo geral, instrumental significa a relação meios-resultados como categoria fundamental para a interpretação de formas lógicas, enquanto operacional exprime as condições graças às quais a matéria: $1^{\circ}$ se torna apta a servir como meio e $2^{\circ}$ efetivamente funciona como meio para a transformação objetiva, que é o objetivo da indagação." Para o autor, instrumentalismo é visto como pragmatismo. Segundo Pierce, pragmatismo é a teoria segundo a qual "uma concepção, ou seja, o significado racional de uma palavra ou de uma expressão consiste exclusivamente em seu alcance concebível sobre a conduta da vida." Para ele, a experimentação faz parte da determinação e qualquer proposição justificada. Pierce acabou por distinguir duas versões fundamentais para o pragmatismo: $1^{\circ}$ um pragmatismo metodológico que é substancialmente uma teoria de significado; $2^{\circ}$ um pragmatismo metafísico, que é uma teoria da verdade e da realidade. Voltando outra vez para Dewey, a essência do instrumentalismo pragmático é conceber o conhecimento e a prática como meios para tornar seguros, na experiência, os bens, que são as coisas excelentes de qualquer espécie (op. cit., pp. 571;784).

Dewey compartilha o experimentalismo de Pierce, ao mesmo tempo em que evidencia o caráter instrumental e operacional de todos os procedimentos do conhecer, considerados como meio para passar de uma situação indeterminada para uma situação determinada, ou seja, ao mesmo tempo distinta e unificada. A tese de James, também, pressupõe que a instrumentalidade do conhecer é o princípio comum do pragmatismo metodológico.

Entretanto, essa tese procura evidenciar a dependência de todos os aspectos do conhecimento ou do pensamento, com relação a exigências da ação, portanto, em relação às emoções em que tais exigências se concretizam. Essas exigências estão implícitas em: valorização das pessoas, confiança na administração e respeito pelas pessoas como aspectos a serem incluídos nos estudos de comprometimento. Dessler (1996, p. 11) afirma:

Uma coisa que se tornou cada vez mais óbvia, à medida que meu estudo prosseguia, foi a criação do comprometimento que requereria um programa administrativo abrangente, composto de um pacote de práticas administrativas concretas e políticas de pessoal. Na falta de tal programa, os resultados dos esforços relativamente unidimensionais, como programas de aumento de qualidade ou planos de incentivo, estão fadados ao fracasso.

Mais adiante, esse autor aborda a importância de metas confluentes entre organização e trabalhador, de modo a obter o comprometimento do funcionário. 
Nesse ponto, Dessler lembra o trabalho de McGregor, que trata da integração entre o indivíduo e as metas da organização, já incluídos na ilustração $\mathrm{n}^{\mathrm{o}}$. 01, evocando os pressupostos $\mathrm{Y}$.

Poucos argumentariam com o fato de que a forma mais poderosa de garantir a execução correta do trabalho da organização é sincronizar as suas metas com as de seus funcionários garantir, em outras palavras, que os dois conjuntos de metas sejam essencialmente os mesmos, de modo que, ao procurar realizar suas próprias metas, o funcionário procure realizar também as metas da organização. Criar comprometimento significa forjar tal síntese. (DESSLER, 1996, p. 11).

$\mathrm{O}$ autor reforça que a criação do comprometimento de funcionários pode ajudar a competir com mais eficácia em períodos prósperos e a reagir a condições adversas. Esses funcionários, segundo ele, ajudarão a empresa a obter uma sensibilidade e conseguir níveis de qualidade e de produtividade que os concorrentes invejarão; farão seu trabalho como se fossem responsáveis diretos pela empresa; mais do que tudo, no entanto, funcionários comprometidos dão o melhor de si para a organização; não necessitarão dos olhos vigilantes de uma equipe de supervisão para realizar suas atividades.

Considere-se que, no comprometimento instrumental, os trabalhadores agem movidos por necessidade e escassez de alternativas imediatas de emprego e instrumental significa a relação meio-resultados.

Como categoria fundamental para a interpretação de formas lógicas indica ficar claro o enquadre com relação à exigência da ação, bem como com relação às emoções em que tais exigências se concretizam para os trabalhadores fazerem as suas escolhas, ainda que as razões de tais escolhas não estejam explicitadas em nível consciente.

Esse raciocínio é reforçado por Becker, (1960, p. 33) que deu origem ao enfoque instrumental do comprometimento organizacional, quando afirma: "comprometimento é uma tendência do indivíduo em se engajar em linhas consistentes de atividade. $\mathrm{O}$ indivíduo permanece na organização devido a custos e benefícios associados à sua saída." Novamente parece ficar claro o processo de escolha, ainda que não explicitadas as condições para tal.

Em seus estudos sobre subjetividade e gestão de pessoas, Davel e Vergara (2001, p. 42) salientam que "[...] focalizar a dimensão intelectual ou puramente instrumental das pessoas, 
tão em moda nos dias atuais, sem considerar, ou pouco considerando, as dimensões física, emocional e espiritual, é um desbalanceamento que pode trazer para as empresas resultados não desejados."

\section{Enfoque 3: No comprometimento normativo, os trabalhadores permanecem na organização movidos por uma obrigação moral.}

Essa abordagem traz o homem reduzido a um objeto que pode ser amplamente compreendido e controlado. Entretanto, via compreensão da natureza e dos processos psicológicos, o homem obtém êxito e tende a comprometer-se quando atua como indivíduo integrado, total, unificado.

$\mathrm{O}$ adjetivo normativo tem dois sentidos principais, que correspondem aos dois sentidos atribuídos à palavra norma: o $1^{\circ}$ é normativo, o qual prescreve a regra infalível para alcançar a verdade, a beleza, o bem, ou seja, um bem absoluto; o $2^{\circ}$ é normativo, uma fórmula técnica que garanta o desenvolvimento eficaz de certa atividade. Na segunda metade do século XIX, foram chamadas de normativas (no $1^{\circ}$ sentido) as ciências filosóficas especiais (lógica, ética, estética), às quais se atribuiu a tarefa de prescrever as normas com as quais o pensamento, a vontade e o sentimento deveriam ajustar-se para alcançar a verdade, o bem e a beleza (WINDELBARD, RICKERT WUNDT, SIMMEL, HUNSERL, dentre outros, op. cit.). Não se pode, porém, negar que existam disciplinas normativas, no $2^{\circ}$ sentido, de formular hipoteticamente técnicas aptas a garantir o desenvolvimento eficaz de determinadas atividades.

No enfoque do comprometimento normativo, os trabalhadores permanecem na organização movidos por uma obrigação moral que pode garantir o desenvolvimento eficiente de certas atividades na organização, mas não necessariamente pode garantir o desenvolvimento eficaz dessas atividades.

Weiner (1982, pp. 419-421) ressaltou que "o elemento central da definição do comprometimento, que faz com que os valores e objetivos organizacionais sejam aceitos, representa uma forma de controle sobre as ações das pessoas e pode ser denominado de normativo-instrumental por ser oriundo geralmente da cultura da organização.”

Ainda que o repertório oriundo da filosofia, contendo envolvimento, compromisso, engajamento, decisão e escolha façam parte, implicitamente, dos estudos dos pesquisadores, 
como Mowday, Porter e Steers (1982), não fica clara a associação entre os componentes desse repertório na elucidação das pesquisas.

Esses autores demonstram que o comprometimento afetivo e o comprometimento instrumental se constituem em constructos distintos e relacionados a diferentes antecedentes, enquanto comprometimento afetivo e comprometimento normativo, embora distintos, estejam relacionados.

No Brasil, estudos empíricos conduzidos por BASTOS (1993, 1994, 1998), abordam as relações entre comprometimento e mudanças organizacionais, padrões de comprometimento e as políticas de gestão de pessoal, verificando-se que as políticas de recursos humanos se mostram articuladas, fornecendo base organizacional ao comprometimento.

Em sua pesquisa, Medeiros (1997, p. 14) afirma que o estudo do comprometimento "reflete uma grande preocupação das organizações em compreender o indivíduo no seu contexto de trabalho conhecendo as variáveis que o motivam, o engajam e o tornam produtivo para a organização.” O autor estudou comprometimento procurando relacioná-lo com a performance dos indivíduos no trabalho, conseqüente mais estudado na literatura do comprometimento.

Reforce-se que o comprometimento no trabalho é tido como um conceito atitudinal, incluindo tendências cognitivas e comportamentais, ainda em construção, impreciso, ambíguo e redundante, de acordo com a literatura pesquisada.

Com vistas a delimitar, objetivamente, o conceito de comprometimento organizacional para fins desta pesquisa, diz-se que tal constructo corresponde às bases que vinculam o indivíduo e a organização, as quais tanto podem estimular esse indivíduo a dispender esforços em prol da organização, quanto podem reduzir a probabilidade de que ele venha a abandoná-la.

O modo como essas bases atuam, tanto para o individuo quanto para a organização, depende do contrato psicológico estabelecido entre ambos.

De acordo com a classificação dada por Handy (1978), o predomínio do tipo de contrato cooperativo é o que melhor se encaixa na necessidade de dar fundamento a essas bases de vínculos. Os estudos sobre comprometimento organizacional no Brasil inserem-se na 
perspectiva "afetiva" preconizada pela literatura e destacam-se os pesquisadores com suas respectivas contribuições, apresentados no quadro $\mathrm{n}^{\circ} .02$.

\begin{tabular}{|c|c|c|}
\hline \multicolumn{3}{|c|}{$\begin{array}{c}\text { QUADRO N }{ }^{\circ} .02 \\
\text { ESTUDOS DESENVOLVIDOS NO BRASIL }\end{array}$} \\
\hline Marcos & Pesquisadores & Contribuições \\
\hline 1989 & $\begin{array}{l}\text { Borges-Andrade, Afanasieff e } \\
\text { Silva } \\
\text { Borges-Andrade, Cameschi e } \\
\text { Silva } \\
\text { Martins, Alves e Menna }\end{array}$ & $\begin{array}{l}\text { Validaram, para o meio Brasileiro, o questionário de comprometimento } \\
\text { organizacional construído por Mowday, Porter e Steers. } \\
\text { Deram continuidade ao estudo dos preditores do comprometimento. } \\
\text { Realizaram estudo buscando apresentar evidências acerca das três } \\
\text { dimensões do comprometimento em agências do setor bancário do Distrito } \\
\text { Federal. Buscaram identificar o grau de comprometimento organizacional } \\
\text { em algumas características demográficas da amostra. }\end{array}$ \\
\hline 1992 & Bastos & $\begin{array}{l}\text { Revisou a pesquisa sobre comprometimento organizacional enfocando os } \\
\text { vínculos indivíduo-organização. }\end{array}$ \\
\hline 1993 & $\begin{array}{l}\text { Borges-Andrade } \\
\text { Borges-Andrade, Afanasieff e } \\
\text { Silva } \\
\text { Borges-Andrade, Cameschi e } \\
\text { Silva } \\
\text { Bastos } \\
\text { Fleury } \\
\text { Rodrigues e Rocha }\end{array}$ & $\begin{array}{l}\text { Realizaram uma análise de conteúdo dos indicadores comportamentais, a } \\
\text { qual permitiu que as seguintes categorias pudessem ser estabelecidas: } \\
\text { compartilhamento (troca de sugestões, experiências entre colegas e } \\
\text { soluções de problemas para a organização); qualidade (produzir um } \\
\text { trabalho de boa qualidade); presença (assi-duidade, pontualidade); } \\
\text { produtividade (desempenho de tarefas); orgulho (divulgar a organização); } \\
\text { doação (dedicação exclusiva, car-ga extra de trabalho) e interdependência } \\
\text { (apontar problemas e soluções). } \\
\text { Realizou estudo de comprometimento em segmento meio e fim da } \\
\text { Administração Pública } \\
\text { Reforçaram suas concluisões de que um dos principais preditores da } \\
\text { rotatividade e do absenteísmo é o comprometimento organizacional. } \\
\text { Ampliaram o estudo dos preditores do comprometimento } \\
\text { Realizou um estudo no qual apresentou um balanço de resultados e de } \\
\text { desafios que cercam a tradição de pesquisa sobre comprometimento. } \\
\text { Estudou comprometimento e qualidade em RH trazendo as estratégias } \\
\text { utilizadas para enfrentar um cenário de mudanças e crises no Brasil, com a } \\
\text { observação da cultura de qualidade em que o comprometimento de todos os } \\
\text { envolvidos desempenha papel essencial na tendência à ruptura com o } \\
\text { sistema taylorista de produção e gestão de RH. } \\
\text { Realizaram estudo objetivando a análise de variáveis comportamentais e } \\
\text { organizacionais no âmbito de escolas públicas com metodologia gerencial, } \\
\text { sem olhar o lado pedagógico. Foram tratadas as variáveis individuais e do } \\
\text { trabalho. }\end{array}$ \\
\hline 1994 & $\begin{array}{l}\text { Bastos (b) } \\
\text { Borges-Andrade } \\
\text { Teixeira }\end{array}$ & $\begin{array}{l}\text { Estudou os múltiplos significados que estão associados ao uso do conceito } \\
\text { comprometimento na linguagem cotidiana, bem como a natureza do } \\
\text { conceito e o seu uso na pesquisa organizacional. } \\
\text { Contribuiu com o estudo da conceituação e da mensuração do } \\
\text { comprometimento organizacional. } \\
\text { Estudou o índice de comprometimento organizacional decompondo-o em } \\
\text { gênero, estado civil, escolaridade, função e permanência no emprego e no } \\
\text { cargo, por meio de análise desses fatores individuais em empresa de pres- } \\
\text { tação de serviços e reforçou a consideração à complexidade organizacional. }\end{array}$ \\
\hline
\end{tabular}




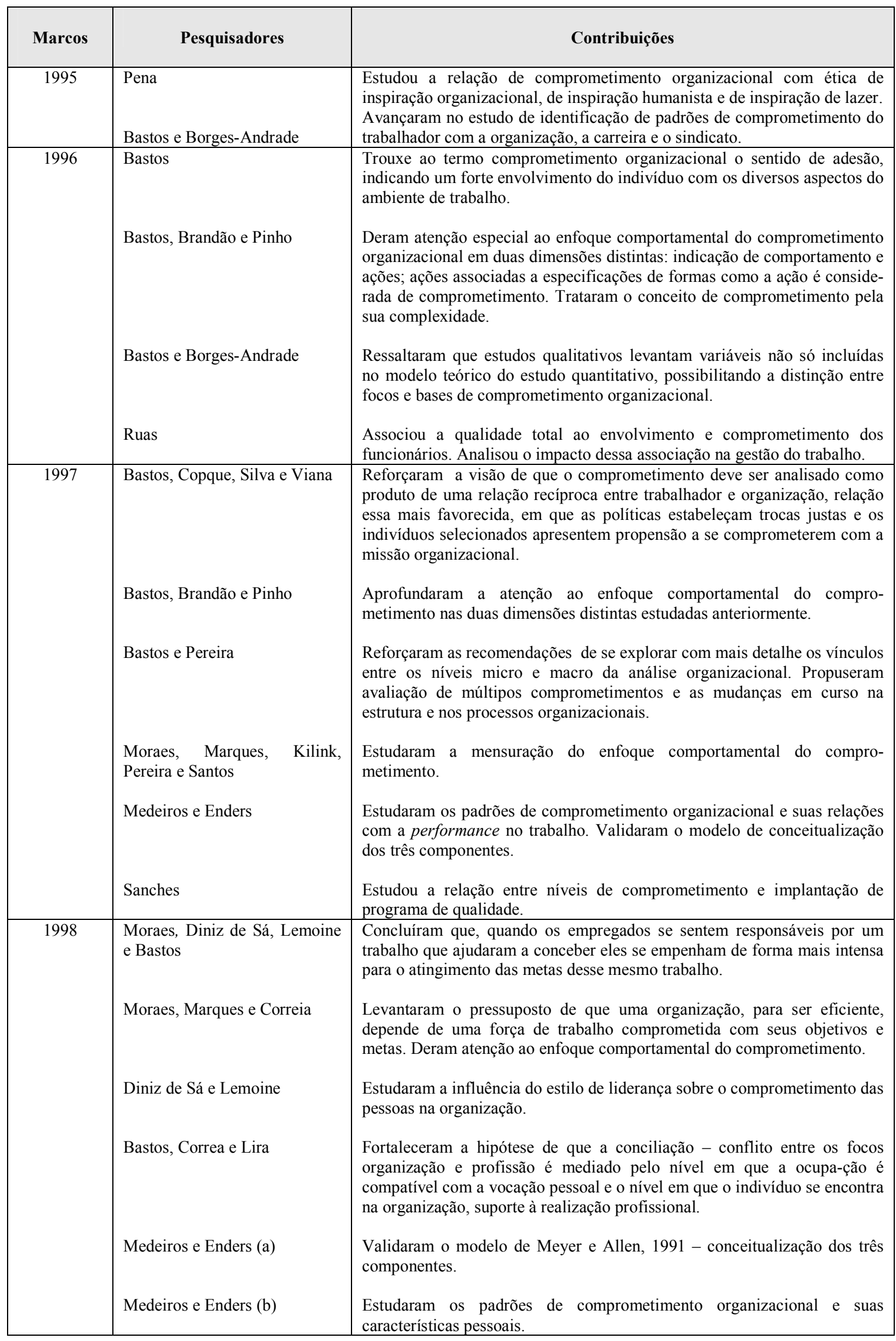




\begin{tabular}{|c|c|c|}
\hline $\begin{array}{c}1998 \\
\text { (cont.) }\end{array}$ & $\begin{array}{l}\text { Bastos } \\
\text { Bastos e Costa } \\
\text { Steil e Sanches }\end{array}$ & $\begin{array}{l}\text { Estudou contextos em mudança e os rumos da pesquisa no domínio do } \\
\text { comprometimento organizacional. } \\
\text { Estudaram os padrões de comprometimento relativos ao trabalho, } \\
\text { vinculando o trabalhador com a organização e o sindicato. } \\
\text { Realizaram estudo sobre comprometimento organizacional como estratégia } \\
\text { de controle, e geraram contribuição para o entendimento do conceito por } \\
\text { meio da análise conjunta com a estrutura e com a cultura organizacionais. }\end{array}$ \\
\hline Marcos & Pesquisadores & Contribuições \\
\hline 1999 & $\begin{array}{l}\text { Albuquerque } \\
\text { Borges-Andrade e Pilati } \\
\text { Bandeira, Marques e Teixeira } \\
\text { Medeiros, Enders, } \\
\text { Oliveira e Monteiro } \\
\text { Antunes e Pinheiro } \\
\text { Bandeira, Marques e Veiga (a) } \\
\text { Rocha e Bastos } \\
\text { Oliveira, Lima e Borges- } \\
\text { Dindrade de Sá e Lemoine } \\
\text { Bastos e Borges-Andrade }\end{array}$ & 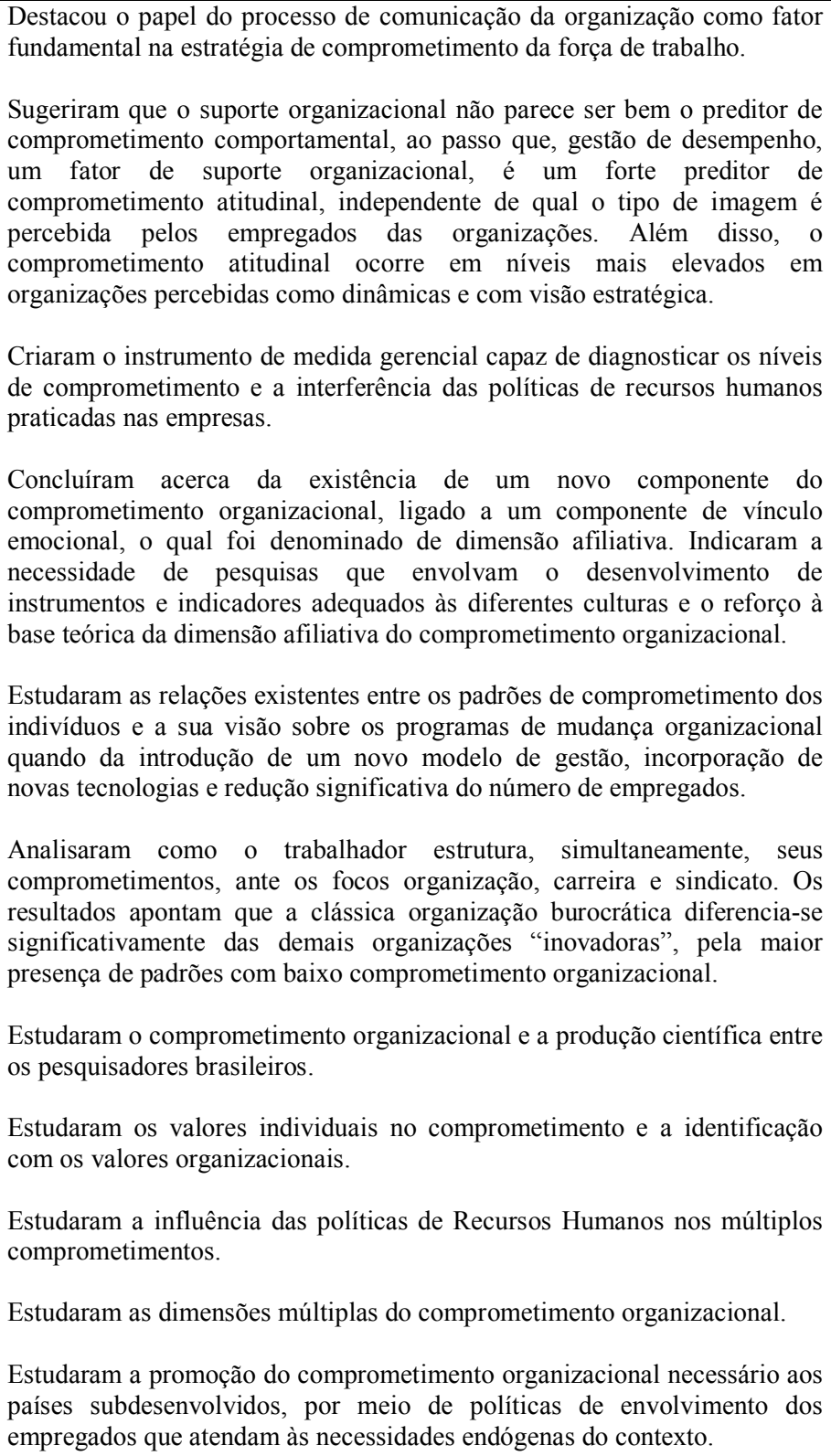 \\
\hline
\end{tabular}




\begin{tabular}{|c|c|c|}
\hline Marcos & Pesquisadores & Contribuições \\
\hline 2000 & $\begin{array}{l}\text { Bastos e Costa } \\
\text { Siqueira } \\
\text { Barbosa e Faria } \\
\text { Pereira e Oliveira }\end{array}$ & $\begin{array}{l}\text { Realizou estudo buscando identificar padrões de comportamento frente à } \\
\text { organização e à profissão, assim como possíveis antecedentes pessoais e do } \\
\text { contexto de trabalho. } \\
\text { Levantaram as congruências e complementaridade entre as estratégias } \\
\text { metodológicas e mostraram a possibilidade de romper o modelo dominante } \\
\text { de estudos quantitativos e a utilização de duas estratégias para analisar os } \\
\text { vínculos de trabalhadores diante dos focos: organização, sindicato e } \\
\text { carreira. } \\
\text { Mostrou os avanços alcançados, limitações conceituais, metodológicas e } \\
\text { técnicas no processo de estruturação do campo de estudo do } \\
\text { comprometimento organizacional, presentes nas disciplinas que } \\
\text { sustentavam suas bases teóricas, tais como Psicologia, Sociologia e } \\
\text { Economia. } \\
\text { Indicaram as condições possíveis em que o comprometimento pode ser } \\
\text { mais bem investigado e o que deve ser levado em conta nas pesquisas } \\
\text { empíricas. } \\
\text { Estudaram a abordagem afetiva proposta por Mowday, Porter e Steers em } \\
1982 \text {, analisando a associação entre maior comprometimento e menor } \\
\text { tempo na função. }\end{array}$ \\
\hline 2001 & $\begin{array}{l}\text { Chang } \\
\text { Siqueira } \\
\text { Borges-Andrade e Pilati } \\
\text { Bastos e Costa } \\
\text { Brito e Bastos } \\
\text { Melo } \\
\text { Rodrigues } \\
\text { Santos e Oliveira }\end{array}$ & $\begin{array}{l}\text { Estudou a avaliação simultânea dos determinantes do comprome-timento } \\
\text { organizacional, levando em conta a cultura da organização. Concluiu que } \\
\text { os elementos que estão envolvidos e, simulta-neamente, são determinantes } \\
\text { desse processo, são constituídos de linearidade e não-linearidade, numa } \\
\text { abordagem sistemicamente complementar e geradora da efetividade nos } \\
\text { resultados individuais e organizacionais. } \\
\text { Apresentou evidências acerca da validade discriminante de três medidas } \\
\text { brasileiras de comprometimento afetivo, instrumental e normativo e suas } \\
\text { relações particulares com três critérios de compor-tamento organizacional: } \\
\text { satisfação no trabalho, comportamento de cidadania organizacional e } \\
\text { intenção de rotatividade. } \\
\text { Sugeriram que diferentes imagens organizacionais são preditoras do } \\
\text { comprometimento afetivo, mas não do comprometimento comportamental. } \\
\text { Trabalharam a articulação de diferentes estratégias de pesquisa para os } \\
\text { múltiplos comprometimentos no trabalho. } \\
\text { Estudaram o comprometimento do trabalhador associado às praticas de } \\
\text { gestão. } \\
\text { Realizou um estudo relacional de comprometimento organizacional, estilos } \\
\text { gerenciais e poder nas organizações. } \\
\text { Estudou o comprometimento organizacional envolvendo a sensibilidade na } \\
\text { prática de troca entre os indivíduos nas organizações. } \\
\text { Indicaram melhoria nas relações de trabalho quando os colaboradores } \\
\text { participavam e se comprometiam com a programação social da empresa. } \\
\text { Indicaram associações entre comprometimento, participação e tempo livre } \\
\text { dos empregados. }\end{array}$ \\
\hline
\end{tabular}




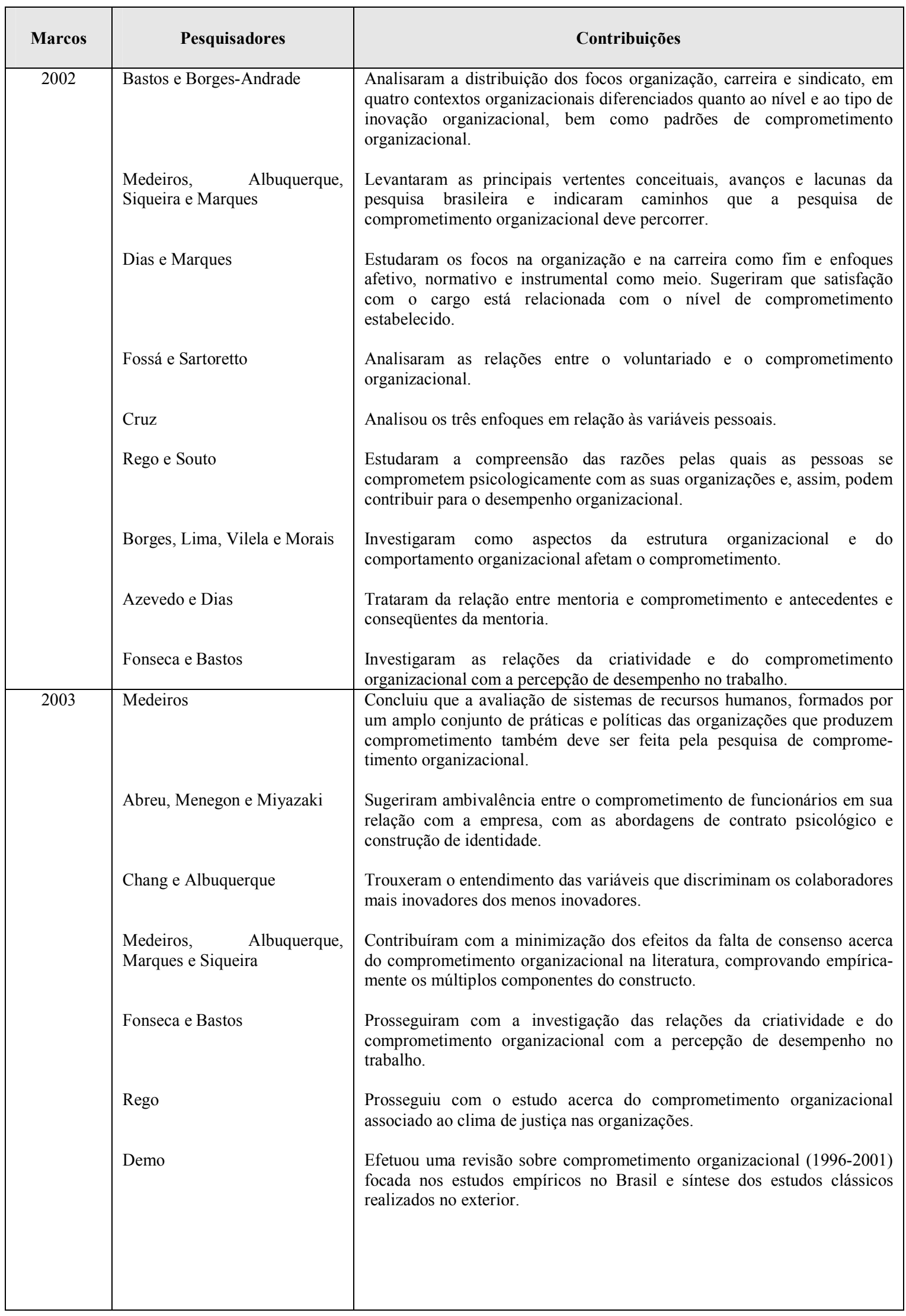




\begin{tabular}{|c|c|c|}
\hline Marcos & Pesquisadores & Contribuições \\
\hline 2004 & $\begin{array}{l}\text { Medeiros, Albuquerque e } \\
\text { Marques } \\
\text { Parolin e Albuquerque } \\
\text { Roquete e Sperling } \\
\text { Rego e Souto } \\
\text { Nascimento, Candatten e } \\
\text { Maciel }\end{array}$ & $\begin{array}{l}\text { Contribuíram para a confirmação de que o comprometimento é } \\
\text { multidimensional e leva a organização a um melhor desempenho. } \\
\text { Indicaram que as competências dos gestores e o clima organizacional } \\
\text { geram ambiente criativo e que o processo criativo gera comprometimento } \\
\text { com resultados. } \\
\text { Concluíram que as variáveis pessoais e funcionais influenciam o } \\
\text { comprometimento nos enfoques comportamental e afetivo. } \\
\text { Aprofundaram os estudos associando comprometimento organizacional e } \\
\text { justiça. } \\
\text { Indicaram que há uma força causal da percepção de clima organizacional } \\
\text { sobre o comprometimento do individuo com a organização. }\end{array}$ \\
\hline 2005 & $\begin{array}{l}\text { Chang e Albuquerque } \\
\text { Costa e Bastos } \\
\text { Sanches, Gontijo, Borba e } \\
\text { Verdinelli } \\
\text { Pilati e Borges-Andrade } \\
\text { Borges, Marques e Adorno } \\
\text { Rabechi e Filenga } \\
\text { Medeiros, Albuquerque e } \\
\text { Marques }\end{array}$ & 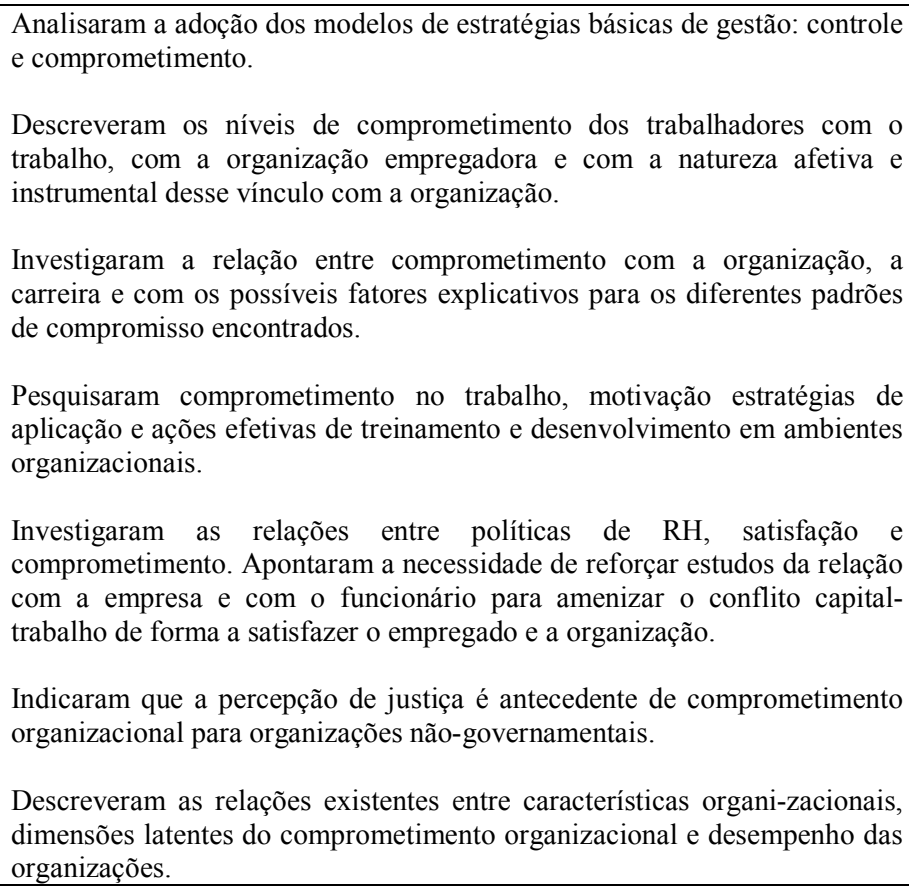 \\
\hline 2006 & $\begin{array}{l}\text { Scheible e Bastos (b) } \\
\text { Soldi e Zanelli } \\
\text { Costa e Moraes } \\
\text { Souto e Rego }\end{array}$ & 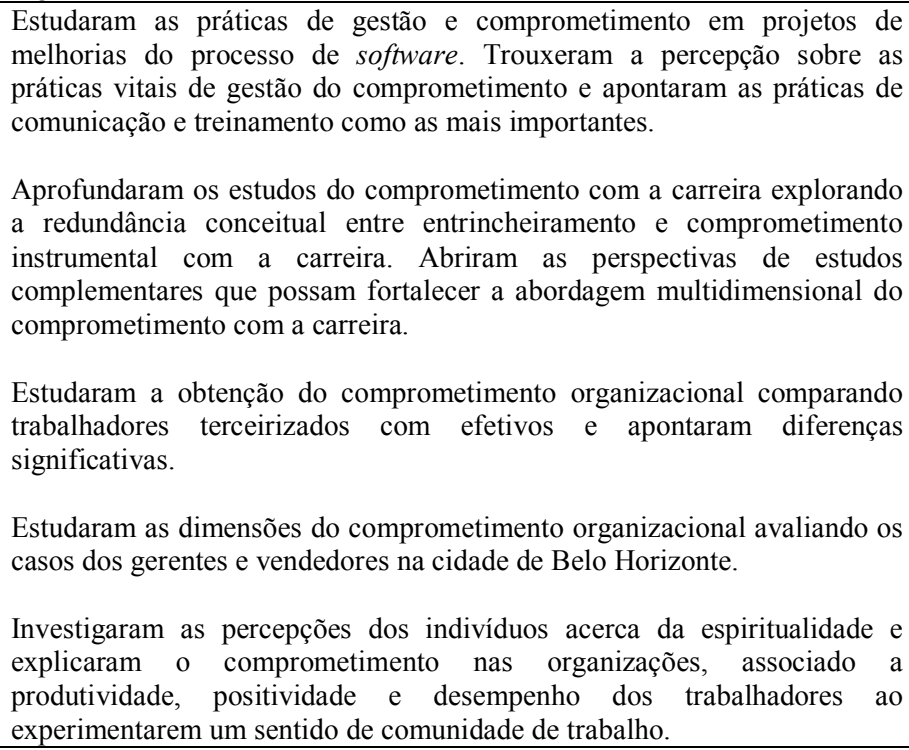 \\
\hline
\end{tabular}




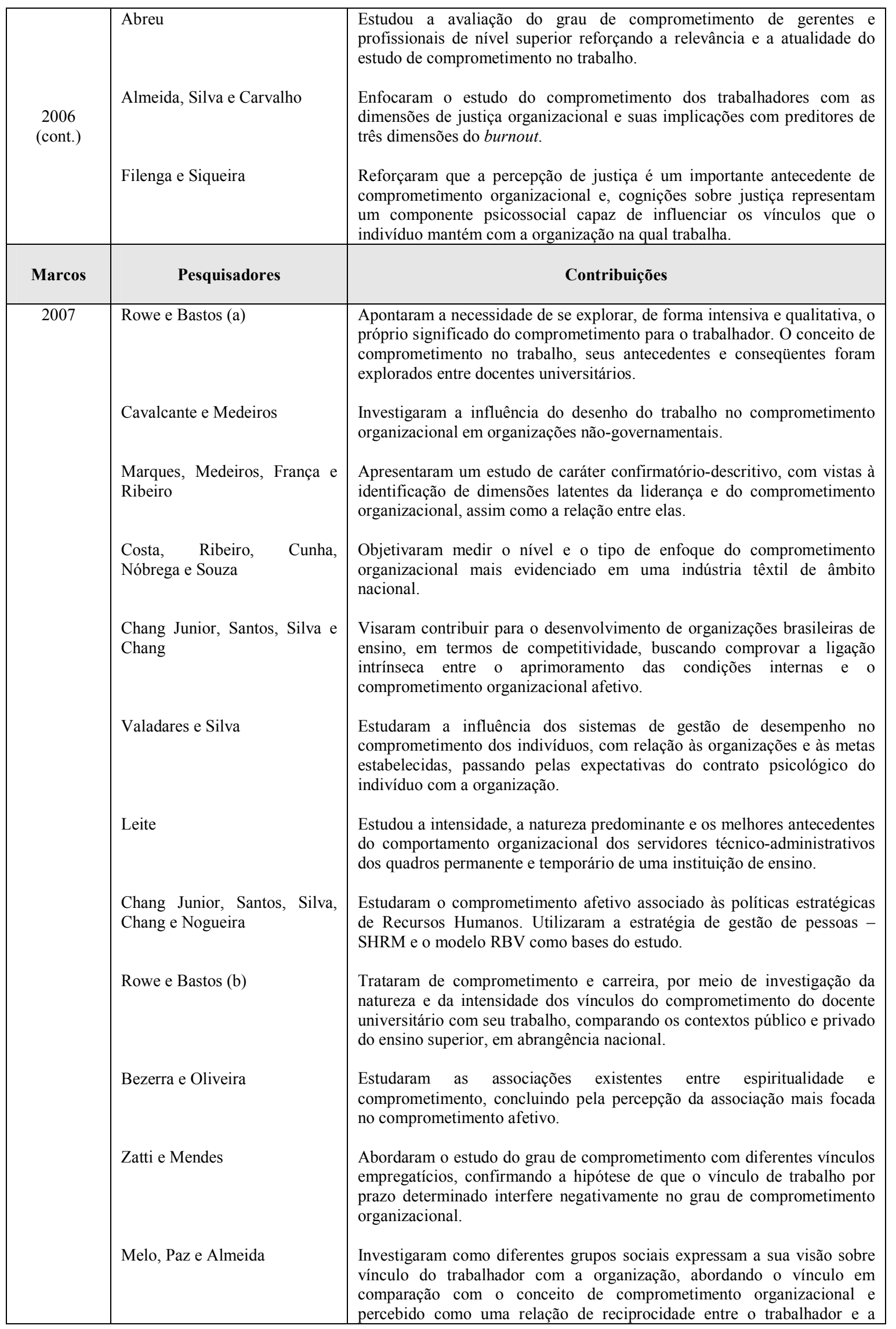




\begin{tabular}{|c|c|c|}
\hline $\begin{array}{l}2007 \\
\text { (cont.) }\end{array}$ & Scheible, Bastos e Rodrigues & $\begin{array}{l}\text { organização. } \\
\text { Exploraram um aprofundamento do comprometimento com a carreira e se } \\
\text { propuseram a questionar e fomentar reflexão sobre as fronteiras e } \\
\text { dimensões do construto, a partir da constatação da redundância conceitual } \\
\text { entre duas dimensões do entrincheiramento e os comprometimentos } \\
\text { instrumental e normativo na amostra estudada. }\end{array}$ \\
\hline & Cançado e Moraes & $\begin{array}{l}\text { Realizaram um estudo de caso em uma empresa, associando o } \\
\text { comprometimento organizacional e as práticas de gestão de RH. }\end{array}$ \\
\hline
\end{tabular}

Esse quadro, em crescente, aponta o rumo que as pesquisas no Brasil vêm tomando, bem como proposições para novas investigações, a partir de linhas já iniciadas.

Note-se que entre os marcos 1989 e 1996 as pesquisas foram realizadas basicamente pelos mesmos estudiosos, com a entrada de um novo nome a cada dois anos-marco. O ano de 1997 consolida-se como o marco para a entrada de diversificados novos nomes, sem que os pioneiros saiam de cena, fato que se reforça no ano de 1999 e se repete até o ano-marco 2007.

O conjunto de dados de pesquisas oriundo desse quadro visa contribuir com o esforço de estudos sobre esse constructo no Brasil, elucidando-se o fato de que a complexidade em sua construção leva à diversidade de abordagens.

\section{4 Gestão estratégica de pessoas}

Esse é um termo, também considerado chave, a ser fundamentado no escopo desta pesquisa. Com essa parte da fundamentação pretende-se consubstanciar o estudo do indivíduo, sentido físico, o indivisível e em sentido lógico, o que não pode servir de predicado. Uno, nas abordagens filosófica e psicológica, passível de assim ser olhado na abordagem administrativa.

$\mathrm{Na}$ filosofia contemporânea, a pessoa é definida em relação com as exigências predominantes nos vários campos da indagação. No campo moral ou político, a pessoa é o indivíduo. $\mathrm{O}$ indivíduo, no conhecimento histórico, tem seu caráter singular e irrepetível.

No bojo desses sentidos, reside o aspecto relevante da indivisibilidade do ser humano tratada pelos filósofos. Casado (2002 a, p. 235) enfatiza esse aspecto, relembrando as características essenciais dos indivíduos dentro do contexto organizacional. "Uma organização é composta de 
pessoas, que trazem para seu interior suas necessidades, interesses, sonhos, potencialidades e limitações. Quando usado como adjetivo, individuo é sinônimo de indivisivo, de algo que não pode ser dividido. E esse significado parece estar definitivamente incorporado às políticas e ações contemporâneas de gestão de pessoas."

Desse modo, a compreensão integral do papel do gestor pode privilegiar a promoção da melhoria da eficácia organizacional, a partir dos indivíduos, dos grupos, das equipes, dos times e da estrutura dentro das organizações.

É por intermédio desses componentes que as organizações propiciam a emergência do simbólico e podem atentar para que a significação não seja reduzida ao trabalho e que possa ser contemplada a existência humana e sua busca constante desse simbólico. No entanto, o estudo de Andion (2002, pp. 3-4) atesta que,

apesar da evolução nos métodos adotados pela gerência, percebe-se uma permanência na definição do gerente como aquele que comanda, orienta e influencia. Por trás desta definição, que é tomada como pressuposto pelas principais correntes administrativas, podemos perceber uma concepção particular do fenômeno gerencial, onde a liderança é reduzida a um processo mecânico de causa e efeito. Nesse processo, o líder (ou gerente) é responsável por articular a visão e ampliar o comprometimento dos trabalhadores [...]

Como deveria, então, desenvolver-se o campo do comportamento organizacional e da gestão de pessoas, de modo a privilegiar a indivisibilidade dos indivíduos para o alcance dos resultados organizacionais?

Casado (2007, p. 213) afirma que "os fundamentos conceituais das ações de gestão de pessoas têm suas raízes no estudo sobre comportamento humano nas organizações." A autora enfatiza a necessidade de se despender tempo e energia no estudo e na compreensão de comportamento organizacional para obter melhor entendimento na aplicação das ferramentas de gestão de pessoas.

O tratamento dado às pessoas, desprovido de conteúdo ético, filosófico e auto-reflexivo, ao que tudo indica, mostra que o campo do comportamento organizacional e da gestão de pessoas parece ter-se desenvolvido negligenciando os conhecimentos das ciências humanas básicas (CHANLAT, 1994; STEYAERT e JANSSENS, 1999). 
Esse negligenciamento, talvez possa ser minimizado com as transformações na função de recursos humanos, que convidam os gestores a combinarem exterioridade e objetividade com as sutilezas e sensibilidades subjetivas para serem capazes de lidar com aspectos relacionais e intrínsecos à natureza humana no âmbito do trabalho e da atividade organizacional.

Considerar as condições subjetivas significa que toda pessoa tem: seu espaço interior, percebe-o como completamente seu, esse espaço relaciona-se com a exterioridade; ele é historicamente construído; é decisivo nas escolhas das pessoas durante sua vida e acaba por provocar mudanças no entorno. Já é observada uma evolução do conceito de administração estratégica de recursos humanos que resulta da crescente necessidade de orientação para planejamento e de intervenções gradativas com orientações estratégicas, visando à mudança do modelo de controle para o de comprometimento (DAVEL e VERGARA, 2001; ALBUQUERQUE 1999). Partindo de uma visão sistêmica, os autores sugerem que diversos subsistemas - a estrutura organizacional, as relações de trabalho e as políticas de RH compõem a gestão de pessoas. Esses subsistemas, compostos de políticas e práticas, podem ser combinados de forma a produzir diferentes estratégias.

A partir das variáveis relevantes dos três subsistemas que compõem a gestão de pessoas, são definidos dois tipos básicos de estratégias de gestão: a) estratégia de controle, na qual os empregados são vistos como números, custos e fator de produção, que, para desempenhar bem as funções, devem ser mandados e controlados; b) estratégia de comprometimento, em que as pessoas são consideradas parceiras no trabalho, nas quais a organização deve investir para conseguir melhores resultados organizacionais e obter valor agregado.

Já foi elucidado que os desafios da evolução do conceito de gestão de pessoas, por meio da mudança da estratégia de controle para a estratégia do comprometimento, sugerem, em última instância, uma deliberação de mudança, em nível comportamental nas organizações, de acordo com Albuquerque (1999). Richard (1997) deixa claro que, na estratégia de controle há pouca definição de políticas em relação à voz do funcionário, a não ser que a força do trabalho fosse sindicalizada e, nesse caso, predominavam as estratégias de controle de danos. O pressuposto desse modelo é de baixo comprometimento do funcionário e destinado a produzir um desempenho confiável. $\mathrm{O}$ autor diz que, na estratégia de comprometimento, esperam-se mudanças nas responsabilidades individuais, à medida que as condições mudem e, as equipes, não os indivíduos, sejam as unidades organizacionais responsáveis pelo desempenho. 
Tal mudança, em nível comportamental, poderá facilitar a criação do valor agregado à organização. Para que a gestão de pessoas crie valor agregado à organização, ela precisa tornar-se um parceiro do negócio em busca dos objetivos estratégicos (MABEY, SKINNER e CLARK, 1998; SCHULER e JACKSON, 1987).

Nesse processo de criação de valor para a organização, Ulrich (1998) propõe um modelo de múltiplos papéis desempenhados pelos profissionais de RH utilizando-se de dois eixos: o do foco que vai do estratégico de longo prazo ao operacional de curto prazo e o eixo das atividades que se estendem da administração de processos à administração de pessoal.

Dentro desse modelo de múltiplos papéis, quatro papéis de RH são definidos: administração de estratégias de gestão, na qual o papel se concentra na participação do processo de definição da estratégia organizacional e concebem estratégias e práticas de gestão de pessoas que sejam alinhadas à estratégia organizacional, transformando o profissional de RH em parceiro estratégico da organização; administração de infra-estrutura da organização, cujo papel tradicional do especialista administrativo consiste em conceber e desenvolver processos eficientes para contratar, treinar, avaliar, premiar, promover e gerir o fluxo de funcionários na organização; administração da contribuição dos funcionários, na qual o papel do defensor dos funcionários é enfatizado e cuja meta é obter maior envolvimento e competência do quadro de pessoal por intermédio da provisão de recursos necessários aos empregados; e administração da transformação e da mudança que tem por objetivo assegurar capacidade para mudança organizacional, transformando o profissional de RH em agente de mudança.

A abordagem da pesquisa voltada para o processo de mudança, mesmo considerando a importância da integração das políticas da administração de recursos humanos, considera, também, o tratamento das pessoas com relação às questões de comprometimento, adaptabilidade e alta qualidade (GUEST, 1987).

Organizações bem-sucedidas reconhecem que incrementos na qualidade e flexibilidade requerem níveis de comprometimento, responsabilidade e conhecimento por parte da força de trabalho, que não podem ser obtidos por coerção ou por "melhorias cosméticas" nas políticas de recursos humanos (DERTOUZOS et al, 1991, p. 124). Com essa afirmação, os autores reconhecem a relevância do comprometimento da força de trabalho das organizações. 
Os gestores podem demonstrar comprometimento com valores, por meio dos seus próprios comportamentos e pelo modo como reforçam o comprometimento de outros. O processo de mobilização do comprometimento deve ser iniciado no topo da organização dentro do círculo dos principais executivos, com abertura para que outros executivos participem do processo de reformulação da cultura organizacional e da internalização da visão nessa cultura. Nesse contexto, deve estar incluído o profissional de RH e o escopo do seu papel como parceiro estratégico.

Autores como Becker, Huselid e Ulrich (2001) argumentam que os profissionais de RH estão aptos para exercer o papel de parceiro estratégico e agregar valor à organização quando compreendem o funcionamento do negócio a ponto de poderem adaptar as políticas e práticas de RH às mudanças nas condições organizacionais. Esses autores defendem que o mau alinhamento entre o sistema de RH e o sistema de implementação da estratégia organizacional pode efetivamente destruir valor.

A participação mais ampla de colaboradores de diferentes níveis da organização é exigida na formulação da estratégia como uma forma de tornar o processo estratégico mais interativo e contínuo, estimulando a comunicação, o aprendizado e o comprometimento das pessoas. No que tange à participação dos profissionais de RH na formulação da estratégia, diversos autores entendem ser esse o novo papel do RH (ALBUQUERQUE, 1987, 2002; ANTHONY, PERREWÉ e KACMAR, 1996; ULRICH, 1998; BECKER, HUSELID e ULRICH, 2001).

A estratégia de gestão de pessoas é um assunto largamente estudado na literatura. Fischer (2002, p. 10) diz: "no campo empírico, nossas pesquisas no Brasil revelaram que nove entre dez formadores de opinião na área de Recursos Humanos acreditam que as políticas e as práticas de gestão de pessoas diferem das utilizadas há dez anos.”

Entretanto, há uma variedade de estudos que apontam a escassez de comprovação dos resultados por ela gerados (WISCOMBE, 2001; CASTER, 2001; WRIGHT et al, 2001; DAVIDSON, 1999).

Um outro aspecto a ser considerado no esforço organizacional de atrair, desenvolver e reter talentos é o da capitalização das competências individuais que agregam valor aos grupos e à organização. Para os pesquisadores que tratam da gestão de pessoas segundo o conceito de competência, a área de recursos humanos deve assumir um papel importante no desenvolvimento 
da estratégia da organização, à medida que cuida com mais propriedade de atrair, manter e desenvolver as competências necessárias à realização dos objetivos organizacionais.

Esses pesquisadores observam que a discussão sobre gestão de competências como alternativa da área de recursos humanos para sua legitimação na esfera decisória e estratégica impõem aos profissionais de RH o desafio de comprovar sua efetividade com resultados tangíveis para a organização (FLEURY e FLEURY, 2004; BARBOSA, FERRAZ e ÁVILA, 2004).

Analisada do ponto de vista de função, a gestão de pessoas tem sido, cada vez mais, apontada como uma das funções-chave para o desenvolvimento e implementação de respostas estratégicas (ULRICH, 1997; YEUNG e BERMAN, 1997).

A estratégia de gestão de pessoas pode ser estudada tomando-se como indicadores as práticas ou funções de gestão de pessoas. Essas práticas consistem em atividades que compõem a estratégia nas organizações. Bohlander, Snell e Sherman (2003) citam recrutamento, seleção, treinamento e remuneração como as práticas fundamentais de gestão de pessoas, como as que são indispensáveis na maior parte das organizações. Robbins (2005, p. 6), em breve revisão do trabalho do executivo, enfatiza que:

Existe um pano de fundo comum às diversas abordagens sobre funções, papéis, habilidades e atividades de administração: todas elas reconhecem a suprema importância da gestão de pessoas. Independentemente de serem chamadas de "função de liderança", "papéis interpessoais", "habilidades humanas" ou "gestão de recursos humanos, comunicação e atividades de interconexão", fica claro que o executivo precisa desenvolver suas habilidades humanas para ser eficaz e bem-sucedido.

Esta pesquisa, em cujos objetivos específicos incluem os de descrever características da estratégia de gestão de pessoas e do comprometimento organizacional no contexto das unidades remotas analisadas e identificar os fatores que facilitam ou dificultam as práticas de gestão de pessoas e o comprometimento organizacional dessas unidades, assume a estratégia de comprometimento como foco relevante.

Tal estratégia, assim como as políticas de recursos humanos, deverá assumir como premissas básicas: a valorização dos talentos humanos; a atração e manutenção de pessoas de alto potencial e qualificação para o trabalho; a criação de condições favoráveis à motivação individual e à mobilização dos grupos em torno das metas organizacionais; a possibilidade de 
desenvolvimento profissional na própria organização; a disponibilização de incentivos vinculados a resultados obtidos pela equipe e adaptação de políticas integradas de recursos humanos à realidade da organização e ao seu contexto de atuação.

A condição de buscar flexibilidade, enriquecer a tarefa, aumentar a qualificação profissional, incrementar a participação dos colaboradores nas decisões, usufruir a criatividade, obter maior comprometimento com as metas, ocorre, principalmente, no trabalho em equipe, em que as comunicações sejam freqüentes e confiáveis. No entanto, há pouca ênfase das organizações brasileiras ao trabalho em equipe, vez que o mesmo pressupõe certa estabilidade da força trabalhadora, alto nível de qualificação e formação, condições essas pouco verificáveis na maior parte da força trabalhadora no país.

Em realidade, no contexto cotidiano dentro das organizações, as comunicações ocorrem, ainda, com ruídos e baixo nível de confiabilidade. Dessler (1996) refere-se à comunicação como um dos principais fatores de comprometimento, enfatizando o ouvir e a confiança como bases de efetivação da comunicação de mão dupla.

No campo da filosofia, Heidegger diz que "comunicação é já a coexistência porque a coparticipação emotiva e a compreensão dos homens entre si fazem parte da própria realidade do homem." Jaspers está substancialmente de acordo com Heidegger e opõe-se às ciências empíricas (psicologia, antropologia, sociologia) que pretendem analisar as relações de comunicação.

Para Jaspers, o defeito dessas ciências é que elas se limitam à consideração das relações humanas, ao passo que a comunicação é, precisamente, possibilidades de relações. Dewey, ao contrário, que compartilha com Heidegger e com Jaspers o ponto de vista de que a comunicação constitui essencialmente a realidade humana, considera-a como uma forma especial de ação recíproca da natureza e acredita, portanto, que pode e deve ser estudada pela pesquisa empírica (op. cit., p. 161)

Comunicação é igual a senso comum, sinônimo de coexistência ou de vida com os outros e indica o conjunto dos modos específicos que a coexistência humana pode assumir, nos quais reste certa possibilidade de participação e de compreensão. 
Filósofos e sociólogos, hoje, utilizam esse termo para designar o caráter específico das relações humanas que podem ser relações de participação recíproca ou de compreensão.

Levando-se ainda em conta alguns dos objetivos específicos da presente pesquisa, como os de caracterizar o ambiente interno (cultura organizacional e estrutura organizacional) de cada unidade das organizações selecionadas e identificar a estratégia de comunicação e o comportamento organizacional de cada unidade dessas organizações serão considerados também relevantes, os aspectos elucidados por Albuquerque (2002, p. 45) "[...] Para a formulação da estratégia de gestão de pessoas, evidentemente, interessa aprofundar os aspectos relativos às dimensões humanas, ou seja, a cultura e as pessoas, e como a interação das pessoas com a estrutura e com o sistema pode contribuir para a consecução dos objetivos estratégicos da organização."

Todavia, há uma diversidade no pensamento do especialista de recursos humanos, que contribui para a heterogeneidade que é observada nas práticas de gestão de RH entre as empresas nacionais. Existem aquelas que mantêm uma abordagem mais operacional, as que adotam uma abordagem mais estratégica e aquelas que se aproximam de uma abordagem mais competitiva (LACOMBE E TONELLI, 2000).

Dentre os aspectos relativos às dimensões humanas, entende-se que a questão da subjetividade precisa ser mais longamente assumida na gestão de pessoas, pois se, mesmo no plano do discurso tal gestão continua a declarar pessoas como estratégias, a questão emergente ainda permanece no nível da objetividade.

Seres humanos não podem ser compreendidos, se a busca dessa compreensão não estiver nutrida por um pensamento filosófico, ético, político e cultural. Considerar a subjetividade significa que "as pessoas estão em ação e em permanente interação, dotadas de vida interior e que expressam sua subjetividade por meio da palavra e de comportamentos não verbais" (DAVEL e VERGARA, 2001, p. 50). De acordo com esses autores, na abordagem da subjetividade, parte-se da premissa de que as pessoas são proativas no processo de produção e capazes de desenvolvimento, confiança e colaboração. Reconhece-se que as necessidades das pessoas, forçosamente, coincidem com as necessidades da organização. 
Essa abordagem traz, novamente, os pressupostos $\mathrm{Y}$ das teorias de McGregor, assim como a lembrança da indivisibilidade da natureza humana abordada pelos filósofos e psicólogos.

As pessoas constituem o sistema social interno, a estrutura define as relações oficiais das pessoas no interior das organizações. As teorias X e Y de Douglas McGregor exercem uma poderosa influência para clarear e maturar o comportamento organizacional (DAVIS, 1983).

\section{5 Cultura organizacional}

A cultura organizacional é considerada como um termo relevante para esta pesquisa por encontrar-se imbricada nos próprios estudos acerca do comportamento organizacional e do comprometimento organizacional.

A inserção do estudo da cultura organizacional em uma pesquisa de comprometimento organizacional obtém sua justificativa em estudo de Chang e Albuquerque (2003, p. 6), quando afirmam:

A própria definição de comprometimento organizacional, segundo Mowday et al (1982), está relacionada a valores e crenças tornando relevante o estudo da cultura que permeia o tecido social da organização como um "pano de fundo" para o melhor entendimento do fenômeno. Pretende-se, através do estudo da cultura, verificar coerências ou associações entre essa cultura, a política de gestão de recursos humanos e o comprometimento dos empregados.

A relevância do estudo da cultura organizacional, nesta pesquisa, respalda-se, ainda, em um dos seus objetivos específicos para a consecução do objetivo principal, o de caracterizar a cultura organizacional de cada unidade das organizações selecionadas para análise, bem como em uma parte da segunda questão de pesquisa, de como se evidenciam as diferenças entre as culturas das unidades remotas dessas organizações.

O conceito de cultura para as ciências administrativas é parte constituinte do ambiente organizacional. Medeiros (2003, p. 28) ressalta que "a atual pesquisa comportamental nas organizações tem percebido que não se pode compreender o indivíduo sem compreender a organização na qual ele está inserido.” 
No campo da filosofia, o conceito de cultura abrange significados diversos, desde a Antiguidade até os dias atuais, para indicar o conjunto de modos de vida criados, adquiridos e transmitidos de uma geração para outra, entre os membros de determinada sociedade. Todos os traços expressos ao longo dos tempos são característicos e se repetem em quase todas as definições que hoje podem ser consideradas válidas.

Por sociedade, entende-se o agrupamento de pessoas que gozam de relativa independência, se mantêm no tempo, cujos membros partilham de crenças, hábitos, costumes e desenvolvem as suas interações primordialmente dentro desse agrupamento.

Nesse agrupamento, a cultura passa a ser representada por tudo que é socialmente aprendido e partilhado pelos seus integrantes.

No campo da antropologia, a base da cultura organizacional está assentada no cognitivo e os conhecimentos compartilhados; no simbólico e os significados compartilhados; no estrutural e os processos psicológicos inconscientes. (FREITAS, 1991).

Em culturas comunitárias, a organização não é a criação ou instrumento de seus fundadores, mas tão-somente um contexto social em que todos os membros compartilham e que lhes dá significado e propósito. Organizações são comparadas freqüentemente a uma comunidade na qual desenvolvem seus membros e podem viver muito mais tempo do que eles podem prever. $\mathrm{O}$ crescimento e a prosperidade das organizações são valiosos fins em si mesmos. (TROMPENAARS e HAMPDEN-TURNER, 1998).

Teoricamente a relevância da cultura é elucidada por alguns estudos e, a razão da escolha inicial recair na pesquisa desenvolvida por Hanashiro, (1995, pp. 27-29), deve-se à afirmação de que "inexiste na literatura administrativa consenso universal sobre o conceito de cultura organizacional."

De acordo com essa autora, "para um conceito mais profundo da cultura - como premissas básicas - qualquer iniciativa de modificá-la exige uma intervenção de mudança de comportamento." A autora enfatiza que "a cultura influencia diretamente o comportamento e ações presentes dos membros de um grupo refletindo a vida organizacional passada." 
Para o desenvolvimento da Teoria das Organizações, a inexistência desse consenso acerca do conceito de cultura organizacional pode significar a oportunidade de maior contribuição dos pesquisadores, quando consubstanciam os seus conceitos nos objetivos e interesses de suas pesquisas, sem perder de vista o valor da diversidade e da especificidade.

Como autor comumente citado, pela riqueza da sua contribuição para a pesquisa desse constructo, Schein (1985, p. 9) chama a atenção para a necessidade de se distinguir a manifestação da cultura em si e se refere à cultura como um "conjunto de pressupostos básicos que algum grupo inventou, descobriu ou desenvolveu ao aprender a lidar com problemas de adaptação externa e integração interna, de tal modo que, se os pressupostos funcionaram suficientemente bem foram considerados válidos e ensinados a novos integrantes como a forma correta de perceber, pensar e sentir, em relação a esses problemas."

Essa conceituação de Schein é uma das mais encontradas entre os estudos dos pesquisadores que se voltam para essa área. Nela observa-se que o autor foi além dos comportamentos diretamente observáveis e dos valores conscientemente justificáveis, trazendo os pressupostos inconscientes que privilegiam a descoberta das razões pelas quais determinado grupo se comporta de dada maneira, assim como os motivos pelos quais um grupo de valores é definido.

De acordo com esse autor (1987), a responsabilidade por sedimentar e reforçar a cultura está associada, também, ao tipo de estrutura organizacional. Se a estrutura é centralizada, reflete a crença de que somente o líder pode determinar o que é melhor; se é descentralizada, reflete uma crença na iniciativa individual e na responsabilidade compartilhada.

Schein (1992) reforça o conjunto de pressupostos básicos enunciados em trabalhos anteriores e reafirma que tais pressupostos podem ser considerados como respostas aprendidas, originárias dos valores proclamados, gradualmente transformáveis em pressupostos subjacentes sobre como as coisas realmente são. Isso se deve ao fato de considerar que, uma vez que um valor é aceito, leva a um comportamento e um comportamento pode levar à resolução dos problemas. Schein advoga, ainda, que a análise da cultura é necessária se se deseja entender como novas tecnologias influenciam e são influenciadas pelas organizações.

Observe-se, nesses estudos de Schein, que a questão do poder não é levada em conta explicitamente. Tal questão é elucidada na proposta metodológica elaborada por Fleury (1996), a 
qual traz a análise de como se organiza um processo de trabalho e permite identificar as categorias presentes na relação de trabalho, o que vem a subsidiar o mapeamento das relações de poder existentes na organização. Essa proposta sugere a possibilidade de vir a ser desvendada a cultura organizacional por intermédio do histórico da organização, do processo de socialização dos novos integrantes, das políticas e sistemas de recursos humanos, da organização do processo de trabalho, das técnicas de investigação, assim como do processo de comunicação formal e informal.

Os estudos de Fleury e Sampaio (2002, p. 293) reforçam a questão do poder, quando definem que "cultura organizacional é o conjunto de valores e pressupostos básicos expresso em elementos simbólicos que, em sua capacidade de ordenar, atribuir significações, construir a identidade organizacional, tanto agem como elemento de comunicação e consenso, como ocultam e instrumentalizam as relações de dominação.” Observe-se, nessa definição, o enriquecimento do trabalho de Schein.

A questão do poder é também elucidada por Silva e Zanelli, (2004, p. 413), segundo os quais a cultura organizacional, além de enfocar o poder, está ligada às questões do controle e da produtividade: "a cultura é compreendida como um instrumento que regula e adapta pessoas e organizações."

Os autores reforçam, ainda, a extrapolação necessária da compreensão do que pode ocorrer além da regulação, do controle e das relações de dominação: "outra idéia subjacente é a de que o controle e o aumento da produtividade, além do uso adequado de técnicas, ocorreriam se os dirigentes compreendessem o comportamento, as expectativas, os pensamentos e os sentimentos dos funcionários.”

Essa idéia subjacente, entretanto, é passível de ser operacionalizada por meio de uma mudança cultural. No entanto, a mudança de cultura dentro de uma organização, também implica uma necessidade de revisão dos valores que a norteiam.

A recomendação de Schein (1987) é a de que o processo de gestão de mudança cultural seja tutorado pelos principais dirigentes da organização.

Esse autor enfatiza que a mudança da cultura, vigente na organização, somente pode ser feita pela constante revisão da significação dos valores básicos, os quais, necessariamente, não são 
alterados e passam por um processo de reinterpretação ante as demandas de adaptação da organização aos seus contextos interno e externo.

A habilidade em lidar com as mudanças, no ambiente organizacional, assim como a sua capacidade criativa são afetadas pelas dimensões de poder e pela cultura organizacional. Para Bertero (1989, p. 29), “a concepção da cultura remonta à etnografia e à antropologia, o que nos indica também um denso poder já muitas vezes exercitado.”

Além da indicação do poder exercitado nas organizações, o equilíbrio do sistema de poder e cultura é identificado em quatro estados, de acordo com Stacey (1991, p. 243): onde há uma clara hierarquia e grande concentração de poder sem compartilhamento dos valores e da cultura leva à força com submissão, baixo consentimento e rebelião dos integrantes; em uma estrutura complexa, na qual o poder é disperso e fracamente exercido, com forte compartilhamento de valores e alto grau de consentimento leva ao vácuo do poder; onde existe uma clara hierarquia e concentração / exercício do poder com forte compartilhamento dos valores e da cultura leva a uma forte integração organizacional, caracterizando autoridade e obediência; onde há a dispersão do poder e fraca intenção de usá-lo, com baixa integração cultural leva à rivalidade.

A cultura institucional permeia a estrutura e os processos organizacionais, podendo influenciar na própria realização da missão da organização, a partir das práticas organizacionais. A utilização de métodos que propiciam a participação nos processos de mudança organizacional cria forte adesão à proposta de transformação (BATAGLIA; FISCHER, 2004).

A estrutura organizacional reflete, além da divisão de tarefas, a distribuição de poder na forma de autoridade. O poder, como influência, ocorre quando o líder apresenta a disposição de utilizá-lo a partir de suas habilidades pessoais em lidar com uma questão, ao tempo em que os liderados demonstram a disposição de consentir e efetivar contribuições.

Nesse contexto, entretanto, há uma exigência por um alto grau de confiança recíproca, assim como por uma clara compreensão dos papéis exercidos e da forma como o poder é utilizado nesse exercício. (STACEY, op. cit.). 
Em ambientes incertos e turbulentos, a eficácia do sistema de poder e cultura organizacional reside em um sistema, em que o poder seja exercido de modo consentido, no qual os valores sejam estabelecidos de forma flexível, possibilitando a integração de alguns poucos princípios da organização com os valores do contexto em que atua.

Compreender o comportamento, as expectativas, os pensamentos e os sentimentos dos funcionários, faz parte do processo de ajudar a compreender o ambiente e determinar como responder a ele com vistas à redução da ansiedade, da incerteza e da confusão, além de ser essa, uma importante função da cultura (YUKI, 1997).

Na visão de Weil (1997, p. 89), “cultura organizacional humana é um conjunto de valores, conhecimentos e costumes ligados a uma visão não fragmentada do mundo, em que a organização é considerada um organismo vivo em constante movimento, constituindo um sistema de eventos com constante interação e interdependência de sistemas maiores ou menores.” Aceitar esse conceito pode implicar em necessidade de profunda transformação. Esse conjunto de elementos é complexo e multidimensional e une, praticamente, tudo o que constitui a vida em comum nos agrupamentos sociais. Além de tudo, o conjunto envolve a ética que, quando compreendida como um valor interno, aquiesce, orienta e conduz à disciplina.

Quando percebida como valor externo, torna-se dicotômica, moralista, contraproducente e desagregadora, uma vez que o poder transformador do ser humano reside no princípio de que ele é um ser dialético e no fato de que a cultura é formada por um conjunto de elementos em relações constantemente dialéticas.

O conceito de Davis (1984, p. 1) é expresso como o "padrão de crenças e valores que proporcionam significados aos membros de uma instituição, provendo-lhes regras de comportamento em suas organizações.”

Essa abordagem permite o compartilhamento do sistema de crenças e valores da organização, quer para fazer escolhas, quer para avaliações dentro dos processos de mudança e transformação cultural, reforçando-se que aqui são trazidos dois processos e não se referem à questão de semântica ou de preciosismo acadêmico. Em um processo de mudança, os elementos constitutivos e indispensáveis que organizam, sustentam e mantêm a cultura precisam ser percebidos pelas organizações como importantes. Dentre esses elementos, o mito 
necessita de atenção especial, uma vez que contribui, substancial e profundamente, para a constituição do sistema de crenças e valores e da identidade. A partir desse elemento, a intervenção de mudança pode vir a ser configurada.

A conceituação de Shrivastava (1985) dá à cultura organizacional o caráter de conjunto de produtos concretos (mitos, sagas, sistemas de linguagem, metáforas, símbolos, cerimônias, rituais, sistemas de valores e normas de comportamento) por meio dos quais o sistema é estabilizado e perpetuado. As relações entre os indivíduos organizam-se baseadas nos mitos e, à medida que eles servem para construir as categorias nas quais as culturas se enraízam, lançam, ao mesmo tempo, as bases dos significados e da comunicação humana, elementos transmissores de um processo planejado de mudança.

Em um processo de transformação, as organizações propiciam a emergência do simbólico e cada mito tem o poder de expressar, com sua linguagem simbólica, não apenas as relações dos homens com a natureza, mas também as relações deles entre si. Morgan (1996, p.132) diz que "ao se falar sobre cultura, na verdade, está sendo feita uma referência ao processo de construção da realidade que permite às pessoas ver e compreender eventos, ações, objetos, expressões e situações particulares de maneiras distintas.”

Se as organizações se apercebem de que os mitos se apresentam como um meio de conhecer e explicar a realidade, como um enunciado sobre a sociedade e sobre a posição que os seres humanos nela ocupam, elas podem vir a facilitar a inserção de cada ser no universo organizacional determinado.

A cultura pode ser considerada como um fenômeno de vida associativa humana, que resulta da combinação de valores, normas, atitudes e outros elementos biopsíquicos e sociais e a cultura como fruto da interação de diversas sub-culturas e com o ambiente externo.

As transformações na cultura organizacional podem vir a ocorrer por meio da comunicação aberta, na qual as equipes possam passar a: integrar o foco das variáveis das pessoas com o foco nas variáveis da cultura organizacional; desenvolver cultura própria, comprometidas com o processo transformador, a partir das atitudes e dos comportamentos. 
A cultura organizacional, como um sistema de crenças e valores compartilhados, influencia o comportamento do trabalhador. Os elementos determinantes nessa influência são as práticas administrativas e a personalidade do(s) fundador (es), bem como a socialização de valores, normas e hábitos essenciais. (DUBRIN 2003).

O impacto da visão, dos valores e da cultura ocupa grande parte da atenção organizacional. Os seus efeitos sobre a vitalidade das organizações são vistos, mesmo quando a capacidade de definir, com precisão, o porquê de forças tão potentes é reduzida. (WHEATLEY, 1992).

Sentidos compartilhados, significados e compreensão constituem formas diferentes de descrever a cultura. O comportamento do indivíduo pode ser tornado sensível e significativo, a depender dos padrões de compreensão que oferecem as bases para tal. Explicitamente, os padrões de comportamento são influenciados pelo ambiente e pelas estratégias. As estratégias definem o que a organização faz. As decisões estratégicas tomadas pelos executivos influenciam no comportamento organizacional, determinam as tarefas, influenciam o projeto organizacional, influenciam e são influenciadas pelo poder na organização.

A associação da criação do comprometimento à estratégia, para que as organizações possam obter êxito, é feita por Dessler (1996, p. 22) que afirma: "No entanto, grande comprometimento não compensará uma estratégia perdida nem superará as ineficiências inerentes a equipes super dimensionadas, ou a perda de tempo proveniente de lentidão dos processos."

A incorporação de novas variáveis aos modelos existentes e a análise dos resultados, em função do contexto cultural de cada organização, podem levar ao melhor entendimento ou à explicação desse fenômeno, o que se torna essencial para a formulação da estratégia de gestão de pessoas, bem como a interação das pessoas com a estrutura. 


\section{METODOLOGIA DA PESQUISA}

Como uma das essenciais preocupações que envolvem um projeto de pesquisa, a metodologia escolhida partiu de: quais questões estudar, quais dados são relevantes, quais dados coletar e como analisar os resultados? Com o seu caráter exploratório, espera-se poder enaltecer a importância das descobertas, dando continuidade à teoria especial sobre comprometimento organizacional.

$\mathrm{Na}$ primeira fase desta pesquisa realizou-se um levantamento bibliográfico sobre comprometimento organizacional e gestão de pessoas, assim como sobre comportamento organizacional e cultura organizacional. Enfatizou-se, em tal levantamento, o estado da arte do constructo comprometimento organizacional no Brasil, além de opiniões reinantes em diversas correntes de pesquisadores.

A partir desse ponto, foram construídos os roteiros de entrevista e observação, com base na fundamentação teórica pertinente aos objetivos e problemas de pesquisa, além de tornar possível estabelecer um arcabouço de referências.

$\mathrm{Na}$ segunda fase, realizou-se um levantamento de campo com vistas a responder às questões de pesquisa, por meio de entrevistas em profundidade e observações nas unidades. Para tanto, utilizaram-se os instrumentos extraídos da primeira fase, assim como realizou-se uma pesquisa documental, por meio de documentos fornecidos pelas unidades remotas pesquisadas.

\section{10 método qualitativo de pesquisa}

O método qualitativo pode ser definido como o que "se fundamenta principalmente em análises qualitativas, caracterizando-se, em princípio, pela não utilização de instrumental estatístico na análise de dados." (VIEIRA, 2004, p. 17). No campo organizacional a pesquisa qualitativa ainda é pouco reconhecida (MORGAN e SMIRCICH, 1980; MERRIAN, 1998; DENZIN e LINCOLN, 2000; PATTON, 2002). 
Tomando-se por base Minayo (2004, pp. 21-22), a possibilidade desse pouco reconhecimento deve-se ao fato de que essa abordagem se apresenta, prioritariamente, "com um nível de realidade que não pode ser quantificado. Ou seja, com universo de significados, motivos, aspirações, crenças, valores e atitudes, o que corresponde a um espaço mais profundo das relações, dos processos e dos fenômenos que não podem ser reduzidos à operacionalização de variáveis.”

A pesquisa qualitativa foi desenvolvida a partir do cruzamento de diversas disciplinas, campos e objetos. De acordo com Denzi e Lincoln (1998, p. 3), ela é "focada em multimétodos, envolvendo uma perspectiva interpretativa e naturalista de seus problemas. Isso significa que os pesquisadores qualitativos estudam os problemas em seus espaços, tentando fazer sentido ou interpretar os fenômenos em termos de significados que as pessoas lhes trazem.”

Nesta pesquisa, a escolha prioritária do método qualitativo recaiu na possibilidade de subsidiar as organizações estudadas, dentro de elementos aqui considerados, na medida em que, de acordo com Richardson (1989), tal método pode permitir analisar aspectos subjetivos tais como: compreensão do contexto da organização, percepções, compartilhamento dos significados e a dinâmica das interações grupais, por intermédio de seus significados para as pessoas.

Acresça-se a isso, o enunciado por Denzi e Lincoln $(1998 ; 2000)$ de que a pesquisa qualitativa envolve a coleta de uma variedade de materiais empíricos - estudos de caso, experiências pessoais, introspecção, história de vida, textos visuais, interativos, históricos e observacionais - os quais descrevem a rotina, os momentos e os significados problemáticos da vida dos indivíduos.

Em termos práticos, alguns autores como Nunan (1994) consideram que não faz sentido separar rigidamente os métodos quantitativo e qualitativo, até porque, ambos podem contribuir no desenvolvimento de um processo de investigação. Para Flick (2004), as abordagens qualitativa e quantitativa privilegiam a visão complementar, em lugar de excludente ou competitiva. 
O mérito da pesquisa qualitativa, ainda que não permita a obtenção de generalizações, reside na exploração de uma situação que poderá servir de subsídio para ações administrativas particulares a uma organização.

Miles (1979, p. 590) considera que "os dados qualitativos são atrativos por muitas razões: são ricos, completos, holísticos e autênticos.” O autor leva em consideração, também, que a principal dificuldade de pesquisa, utilizando-se dos dados qualitativos, é que ao contrário dos dados quantitativos, os métodos de análise ainda não estão bem formulados.

Para Vieira (2004, pp. 15-17), “o método qualitativo é definido de acordo com o axioma de crenças do investigador e atribui importância fundamental à descrição detalhada dos fenômenos e dos elementos que o envolvem, aos depoimentos dos atores sociais envolvidos, aos discursos, aos significados e aos contextos.”

Dentre a identificação dos cinco principais tipos de estratégia de pesquisa, elucidada por Merrian (1998), escolheu-se a de estudo de caso pelas seguintes razões: essa estratégia de pesquisa é abrangente e inclui tanto estudos de caso único quanto de múltiplos casos; os estudos de caso colocam mais ênfase em uma análise contextual completa de poucos fatos ou condições e suas inter-relações (COOPER e SCHINDLER, 2003); tal estratégia, com base em Eisenhard (1989), pode ser realizada, dependendo da técnica utilizada na coleta, análise e interpretação dos dados; é apropriada, de acordo com Yin (2005), por: não exigir controle sobre eventos comportamentais; focalizar acontecimentos contemporâneos; acrescentar fontes de evidências como entrevistas de pessoas envolvidas nos acontecimentos que estão sendo estudados; realizar observação desses acontecimentos, documentos e artefatos; possibilitar a investigação de um fenômeno e seus conteúdos da vida real, quando as fronteiras entre o fenômeno e o contexto ainda não estão claramente evidentes.

Essa metodologia também permite que o pesquisador use o 'oportunismo controlado' para responder, com flexibilidade, às novas descobertas, ao tempo em que se coletam novos dados (EISENHARD, 1989).

O conceito de estudo de caso, aqui utilizado, como método de pesquisa social empírica, toma por base as características tecnicamente expostas por Yin (2005, pp. 32-33). 
A primeira parte da sua definição técnica diz respeito ao escopo do estudo de caso: "um estudo de caso é uma investigação empírica que investiga um fenômeno contemporâneo dentro de seu contexto da vida real, especialmente quando os limites entre o fenômeno e o contexto não estão claramente definidos.” A segunda parte da definição técnica do autor será apresentada na estratégia de coleta dos dados, item 3.3.

Como o critério de escolha dos casos envolveu unidades com estruturas organizacionais remotas, a estratégia metodológica de estudo de caso foi escolhida por ser particularmente adequada para responder a questões do tipo 'como', bem como por ser apropriada para gerar e construir teoria em uma área sobre a qual o pesquisador não tem total controle (YIN, 1994).

Com a investigação em casos múltiplos, nesta pesquisa, puderam ser identificadas as vantagens de que a teoria em questão, subjacente ao estudo, é de natureza holística e não há a identificação de nenhuma subunidade lógica.

\section{2. Critérios utilizados para a escolha dos casos}

Por estar associada a um dos maiores desafios de uma pesquisa dessa natureza, que é o acesso ao campo (YIN, 2002; CRESWELL, 2003), a investigação da viabilidade de acesso às seis organizações do setor industrial brasileiro, em unidades com estruturas organizacionais remotas, foi feita e contou com sua receptividade e seu apoio.

Quanto maior o número de casos e unidades de análises, maior a possibilidade de triangulação, desde que esses casos tenham algo em comum. Parte-se da premissa de que, muito embora fatores como o desenvolvimento que torna determinada região menos inóspita e a revolução tecnológica (comunicação) que reduz as distâncias, os desafios para atração e retenção de talentos (colaboradores) e suas famílias, ainda permanecem, nas unidades com estruturas organizacionais remotas.

Foi considerada como critério de escolha do universo desta pesquisa, a estrutura organizacional (departamentalização e atribuições) para gerenciar a infra-estrutura necessária à instalação das pessoas em dada região, distante dos grandes centros urbanos, criada ou adaptada pelas organizações para o funcionamento de unidades operacionais nela instaladas, 
com a finalidade de maximizar os recursos disponíveis nessa região, aqui denominada de estrutura organizacional remota.

\section{3 Estratégia de coleta dos dados}

O nível proposto de análise foi o organizacional e a pesquisa envolveu grupos de análise constituídos de diretores, gerentes, profissionais de recursos humanos, coordenadores e supervisores de cada unidade estudada nos seis casos. Conforme recomendado por Eisenhard (1989), esta pesquisa utilizou-se da combinação dos seguintes métodos de coleta de dados: entrevistas, observações nas unidades remotas e análise de documentos sobre as especificidades dessas unidades. A recomendação dessa combinação está em linha com o fato de que a coleta de dados e as estratégias de análise de dados compõem a segunda parte da definição de Yin (2005, pp. 32-33)

A investigação de estudo de caso enfrenta uma situação tecnicamente única em que haverá muito mais variáveis de interesse do que pontos de dados, e, como resultado, baseia-se em várias fontes de evidências, com os dados precisando convergir em um formato de triângulo, e, como resultado, beneficia-se do desenvolvimento prévio de proposições teóricas para conduzir a coleta e a análise de dados.

Para esta pesquisa adotou-se, portanto, o triângulo: entrevista, observação nas unidades e análise de documentos fornecidos pelas empresas.

A principal fonte primária dos dados foi a entrevista em profundidade, com amostra reduzida. Para Selltiz et al. (2005, p. 40),

[...] a flexibilidade da entrevista não estruturada, se apropriadamente empregada, ajuda a determinar os aspectos efetivos e valorativos das respostas dos entrevistados e a determinar o significado pessoal de suas atitudes. Ela não apenas permite que o entrevistado se expresse em detalhe quanto ao assunto da entrevista, mas também pode eliciar os contextos sociais e pessoais de crenças e sentimentos. Este tipo de entrevista atinge seus propósitos à medida que as respostas dos entrevistados são espontâneas e não forçadas, altamente específicas e concretas, ao invés de difusas e gerais, sendo pessoais e auto-reveladoras, ao invés de superficiais.

A utilização de entrevistas dessa natureza, como base dos dados da pesquisa, ofereceu vantagens quanto à espontaneidade e ao livre arbítrio para o respondente avaliar a relevância do tema. A desvantagem consistiu no fato de que essas entrevistas poderiam se prolongar em 
função das características pessoais do respondente. Por tal risco, o cuidado precisou ser redobrado para não causar prejuízos ao atingimento dos objetivos da pesquisa.

As entrevistas foram conduzidas por um roteiro, subdividido em questões específicas de cada um dos quatro termos considerados relevantes e especificados na Fundamentação Teórica. $\mathrm{O}$ pré-teste foi realizado com nove ex-integrantes de equipes remotas, oriundos de sete unidades de regiões distintas de uma mesma organização, com vistas a reconhecer a validação qualitativa do roteiro da entrevista.

O resultado obtido foi validado, em grupo, pelos nove participantes que realizaram a validação individual. Nesse grupo foi verificada a pertinência das questões com as categorias de análise e objetivos da pesquisa. Não houve pretensão de análise estatística da validação. Fizeram-se os ajustes necessários após o pré-teste.

O roteiro da entrevista foi elaborado com base nesses quatro termos, com o objetivo de abarcar levantamento de fatos, opiniões, sentimentos, crenças, atitudes e comportamentos. As entrevistas transcorreram, como esperado em todas as unidades, com duração aproximada de duas horas.

A segunda fonte primária foi a observação estruturada em roteiro, com o qual se pôde usufruir visita às áreas operacionais de todas as unidades remotas, além da observação não estruturada e sistematizada, ocorrida nos momentos de espera para as entrevistas e deslocamentos internos, circunstâncias favoráveis ao processo de observar naturalmente o comportamento das pessoas em seu ambiente natural. A coleta de dados secundários consistiu em levantar informações em documentos fornecidos pelas empresas pesquisadas, bem como em seus sites.

\section{4 Técnicas aplicadas ao tratamento dos dados}

A análise de conteúdo é considerada uma técnica para o tratamento de dados, que visa identificar o que está sendo dito a respeito de determinado tema. A metodologia reflexiva caracteriza-se pelo fato de que, todas as referências para dados empíricos são resultados de interpretação e reflexão. (VERGARA, 2005). A autora enfatiza que na metodologia reflexiva, fundamentação teórica e coleta de dados empíricos caminham conjuntamente. 
Foi enfatizada por Marconi e Lakatos (1982), a idéia que a análise de conteúdo, além de voltar-se para o estudo das idéias, ao invés das palavras, é uma técnica que tem como alvo os produtores da ação humana.

Segundo Bardin (1977, p. 42), a análise de conteúdo é: "um conjunto de técnicas de análise das comunicações visando obter, por procedimentos sistemáticos e objetivos de descrição do conteúdo das mensagens, indicadores (quantitativos ou não) que permitam a inferência de conhecimentos relativos às condições de produção / recepção destas mensagens." Para essa autora, a análise de conteúdo não deve ser nem doutrinária nem normativa.

$\mathrm{Na}$ análise quantitativa, a autora enfatiza que o que serve de informação é a contagem com que surgem certas características do conteúdo. $\mathrm{Na}$ análise qualitativa é a ausência ou presença de determinada característica de conteúdo ou de um conjunto de características em um dado fragmento de mensagem que é levado em consideração.

A combinação da compreensão clínica com a contribuição estatística é aceita mais favoravelmente. Tal combinação corrobora Nunan (1994), quando afirma que tanto o método quantitativo quanto o qualitativo, em conjunto, podem contribuir para o desenvolvimento de um processo de investigação; Flick (2004), ao afirmar que a abordagem qualitativa, conjuntamente com a quantitativa, privilegia a visão complementar.

Selltiz, Wrightsman e Cook (2005), enfatizam que as análises de conteúdo são realizadas com base em alguns critérios, quais sejam: as categorias de análise, usadas para a classificação do conteúdo, são clara e explicitamente definidas, de modo que outros indivíduos possam aplicá-las ao mesmo conteúdo, com vistas à verificação de suas conclusões; o pesquisador não pode selecionar e descrever apenas o que the parece interessante, mas precisa classificar metodicamente todo o material significativo de sua amostra; algum processamento quantitativo é utilizado, visando conseguir uma medida da importância e da acentuação, no material, das várias idéias encontradas, e permitir comparação com outras amostras de material.

A análise de conteúdo parece útil à medida que a sua sutileza metodológica corresponde aos objetivos de ultrapassar a incerteza e enriquecer a leitura. 
Ainda com base em Bardin (op. cit. pp. 37-39), a análise de conteúdo “[...] é, portanto um método taxionômico bem concebido para satisfazer os colecionadores (sic) preocupados em introduzir uma ordem, segundo certos critérios, na desordem aparente." Suas etapas compreendem: a descrição, a inferência e a interpretação.

A descrição corresponde à enumeração das características do texto, resumida após tratamento. A inferência é o procedimento que permite responder a duas questões: o que conduziu a um determinado enunciado? Quais as conseqüências que um determinado enunciado provavelmente provocará? A interpretação corresponde à significação concedida às características do texto.

Para que essas etapas pudessem ser bem explicitadas nesta pesquisa e manter a precisão da análise procedeu-se à leitura flutuante, como pré-análise, organizando-se e preparando-se o material; fez-se a exploração do material na análise, realizando-se operações de codificação; trataram-se os resultados obtidos com base na inferência e interpretação, procurando-se extrair, por meio de um processo de deduções lógicas, atitudes, valores e símbolos que constituem a estrutura do significado subjacente. Considerou-se tal procedimento indispensável para minimizar o risco de: compreensão espontânea; geração de material superficial, analisado linear e descritivamente; interpretações destituídas de fundamentação lógica.

Bardin (op. cit.) elucida que a análise de conteúdo possui duas funções que podem ou não dissociar-se na prática: a heurística que enriquece a tentativa exploratória e aumenta a propensão à descoberta; a de administração da prova que serve de verificação no sentido de uma confirmação.

Não obstante a análise de conteúdo ser considerada como um conjunto de técnicas de análise das comunicações, por intermédio de procedimentos sistemáticos e objetivos de descrição do conteúdo das mensagens, isso não é suficiente para definir a especificidade da análise de conteúdo. E, embora tenha sido concebida com base na quantificação, a análise de conteúdo pode admitir a abordagem tanto a quantitativa quanto a qualitativa ou ambas, uma vez que elas não são mutuamente excludentes e podem ser usadas de forma complementar.

A análise de conteúdo exige como regras para a categorização dos conteúdos, categorias exaustivas, mutuamente exclusivas, homogêneas, objetivas para fundamentar impressões e juízos intuitivos, por meio de operações conducentes a resultados de confiança e pertinentes (BARDIN, 1977; FREITAS, CUNHA JR. e MOSCAROLA, 1996; LAVILLE e DIONNE, 1999). 
Metodologicamente, a evolução da análise de conteúdo tem como foco central o alcance das análises. Esse alcance deixa de ser exclusivamente descritivo e passa a produzir inferência. A mudança de alcance propicia a possibilidade de revelação de outros significados subjacentes que os conteúdos podem trazer.

Bardin (1977, p. 21) enfatiza que tal evolução foi fundamental, pois: “[...] a exigência de objetividade torna-se menos rígida, ou melhor, alguns pesquisadores interrogam-se acerca da regra legada pelos anos anteriores, que confundia objetividade e cientificidade com a minúcia da análise de freqüências."

$\mathrm{Na}$ primeira fase desta pesquisa procurou-se facilitar o tratamento dos dados, por intermédio do que Vergara (2005) considera grade fechada para a definição das categorias para análise, elegendo-se as quatro categorias: comportamento organizacional, comprometimento organizacional e cultura organizacional. Na medida em que essas categorias eram pertinentes aos objetivos e problemas da pesquisa, e mostravam-se alinhadas à fundamentação teórica, buscou-se identificar no material selecionado em cada unidade remota os elementos a serem integrados nessas categorias já estabelecidas.

À medida que a pesquisa de campo avançava, novas categorias de análise surgiram e se procedeu ao rearranjo dessas categorias durante o andamento. Vergara (op.cit.) considera que essas novas categorias fazem parte da grade aberta. Ao estabelecer o conjunto final de categorias e considerar o possível rearranjo, formou-se, então, o que a autora considera de grade mista, podendo-se considerar que, para esta pesquisa foi utilizada a grade mista de categorias.

Para a transformação dos dados brutos dos textos das entrevistas, nesta pesquisa, cujo tratamento do conteúdo foi traduzido pela natureza qualitativa, a escolha das unidades de análise dos conteúdos constitui-se em elemento central. Como auxiliar, foi feita a contagem de freqüência da presença e ausência das unidades de codificação no texto das entrevistas em profundidade, realizadas em cada unidade com estrutura remota das empresas pesquisadas.

O procedimento de análise de conteúdo das entrevistas apoiou-se predominantemente em procedimentos interpretativos. Nesse ponto o problema de pesquisa foi resgatado e os resultados obtidos foram confrontados com as teorias. 
A metodologia reflexiva foi utilizada para a interpretação dos dados empíricos oriundos das entrevistas e observações, bem como para a interpretação dos pressupostos teóricos que respaldaram a pesquisa empírica. Também foi utilizada a análise documental das especificidades de cada unidade remota.

\section{5 Modelo teórico da pesquisa}

Por tratar-se de um estudo de casos, acredita-se que, não necessariamente, um modelo teórico pode ser eleito e seguido na íntegra. Para interpretar as organizações em seu contexto de vida real, buscou-se privilegiar a riqueza dos dados da realidade e surpresas que porventura pudessem vir a ser encontrados.

Tais surpresas podem permitir uma formatação criteriosa de categorias que realmente representem as variáveis mais significativas. As amarrações desta pesquisa estão apresentadas no quadro $\mathrm{n}^{\circ} .03$.

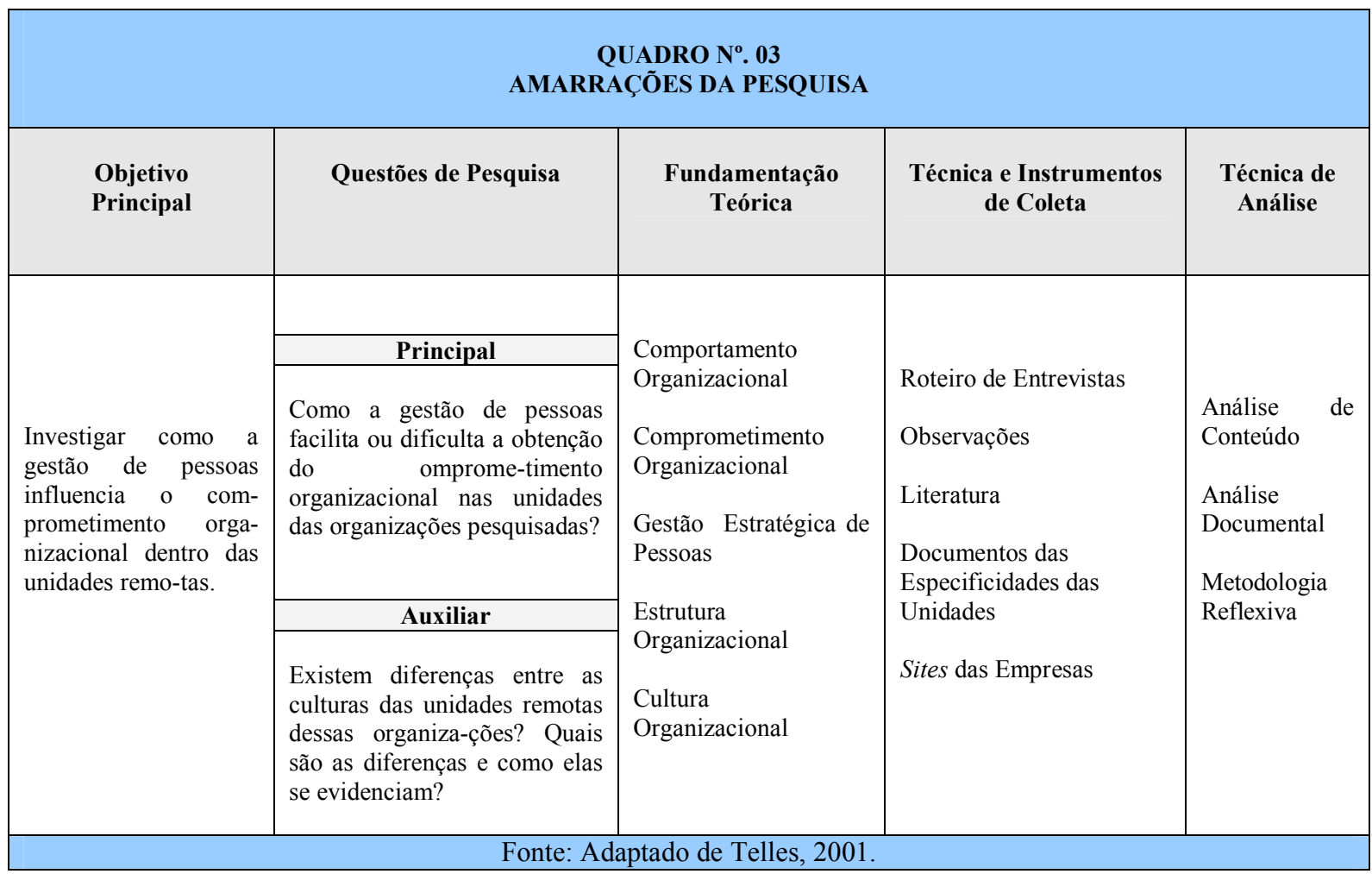




\section{APRESENTAÇÃO E ANÁLISE DOS RESULTADOS}

O nível de análise escolhido foi o organizacional. O grupo de entrevistados, em cada empresa/unidade remota, foi sugerido em razão desse nível de análise. Observe-se que o tamanho do grupo, também, é diferenciado em virtude das possibilidades encontradas na estrutura organizacional de cada empresa / unidade remota na ocasião da pesquisa de campo.

As unidades de codificação, representadas por palavras-tema e respaldadas por palavras-chave ou frases-chave, foram tomadas de segmentos do conteúdo das entrevistas constituídos de significação para os objetivos da pesquisa.

O primeiro resultado da análise de conteúdo foi obtido tomando-se a categorização de cinqüenta e duas palavras-tema registradas nas entrevistas e reagrupadas em vinte e oito, consideradas como pertinentes aos objetivos da pesquisa, encontradas em todas as empresas/unidades remotas, de modo a oferecer um parâmetro comum a todas elas.

Esse reagrupamento foi feito observando-se a seqüência na qual pudessem ser contemplados os termos relevantes desta pesquisa: comportamento organizacional, comprometimento organizacional, gestão de pessoas e cultura organizacional.

Do mesmo modo, procedeu-se ao agrupamento das palavras-chave ou frases-chave que melhor representassem as vinte e oito palavras-tema agrupadas, como unidades de codificação, em cada uma das unidades remotas pesquisadas.

Para mostrar a presença ou ausência dessas palavras ou frases escolheu-se, auxiliarmente, fazer a contagem do número de vezes em que elas estiveram presentes ou ausentes em cada unidade remota e sem contar a ocorrência das repetições dessas palavras ou frases no conteúdo de uma mesma entrevista. Para tanto, considerou-se o que é dito por Bardin (1977): na análise qualitativa, a presença ou ausência de uma dada característica de conteúdo ou de um conjunto de características num determinado fragmento de mensagem é o que se leva em consideração, ao tempo em que, na análise quantitativa, o que serve de informação é a freqüência com que surgem certas características do conteúdo. 
O resultado pode ser visto no quadro "Resultado da Análise de Conteúdo" de cada unidade remota pesquisada. A primeira sistematização forneceu o material básico para uma análise descritiva do conteúdo das entrevistas, evidenciado pelas palavras-tema surgidas na pesquisa.

A partir dessa primeira sistematização, foi possível obter o resultado da análise de conteúdo aplicada ao escopo da pesquisa. Isso significa que se fez uso do que é denominado por Vergara (2005) de grade fechada de categorização para as categorias de análise aqui representadas por: comportamento organizacional, comprometimento organizacional, gestão de pessoas, cultura organizacional.

Os temas significativos foram escolhidos pelo critério de categorização que englobasse todas as empresas/unidades remotas pesquisadas. As especificidades de cada uma dessas unidades remotas foram registradas como unidades de codificação. Os resultados, por cada caso estudado, são apresentados no quadro "Resultado da Análise de Conteúdo Aplicado ao Escopo da Pesquisa" para cada uma das unidades remotas envolvidas nos respectivos casos.

As unidades de análise desta pesquisa são seis empresas brasileiras e suas respectivas unidades com estruturas organizacionais remotas, escolhidas e autorizadas para as investigações, apresentadas concentradamente no quadro $n^{\circ} .04$.

\begin{tabular}{|c|c|c|}
\hline \multicolumn{3}{|c|}{$\begin{array}{c}\text { QUADRO No. } 04 \\
\text { CARACTERIZAÇÃO DAS EMPRESAS / UNIDADES REMOTAS }\end{array}$} \\
\hline $\begin{array}{l}\text { Companhia Vale do Rio Doce } \\
\text { Unidades }\end{array}$ & Características & Regiões \\
\hline Paragominas & $\begin{array}{l}\text { Nova, remota, isolada e não confinada. Extração de } \\
\text { bauxita. Adaptções na infra-estrutura existente na } \\
\text { cidade. }\end{array}$ & Sudeste do Pará \\
\hline Itabira & $\begin{array}{l}\text { Antiga, remota, não isolada e não cofinada. Extração de } \\
\text { ferro. Criação subsidiada da infra-estrutura da cidade. }\end{array}$ & Centro de Minas Gerais \\
\hline Porto Trombetas & $\begin{array}{l}\text { Antiga, remota, isolada e confinada. Extração de } \\
\text { bauxita. Criação da infra-estrutura da vila. }\end{array}$ & Oeste do Pará \\
\hline Serra dos Carajás & $\begin{array}{l}\text { Antiga, remota, isolada e confinada. Extração de ferro e } \\
\text { manganês. Criação da infra-estrutura da vila. }\end{array}$ & Sul / Sudeste do Pará \\
\hline Canaã dos Carajás & $\begin{array}{l}\text { Nova, remota, semi-isolada e semi-confinada. Extração } \\
\text { de cobre. Criação subsidiada da infra-estrutura da } \\
\text { cidade. }\end{array}$ & Sul / Sudeste do Pará \\
\hline
\end{tabular}




\begin{tabular}{|c|c|c|}
\hline $\begin{array}{c}\text { CADAM / Pará Pigmentos } \\
\text { Unidades }\end{array}$ & Características & Regiões \\
\hline Ipixuna & $\begin{array}{l}\text { Antiga, remota, isolada e confinada. Extração de } \\
\text { caulim. Criação da infra-estrutura de alojamentos. }\end{array}$ & Nordeste do Pará \\
\hline Monte Dourado & $\begin{array}{l}\text { Antiga, remota, isolada e confinada. Extração de caulim. } \\
\text { Criação da infra-estrutura da vila. }\end{array}$ & Norte do Pará \\
\hline Barcarena & $\begin{array}{l}\text { Antiga, semi-remota, semi-isolada e não confinada. } \\
\text { Expedição do minério. Criação da infra-estrutura da vila. }\end{array}$ & Norte do Pará \\
\hline $\begin{array}{l}\text { Grupo ORSA } \\
\text { Unidades }\end{array}$ & Características & Regiões \\
\hline Jarí Celulose & $\begin{array}{l}\text { Antiga, remota, isolada e confinada. Extração de } \\
\text { celulose. Criação da infra-estrutura da vila. }\end{array}$ & Norte do Pará \\
\hline Orsa Florestal & $\begin{array}{l}\text { Nova no Norte, remota, isolada e confinada. Preservação } \\
\text { florestal. }\end{array}$ & Norte do Pará \\
\hline Fundação Orsa & $\begin{array}{l}\text { Nova no Norte, remota, isolada e confinada. Trabalhos } \\
\text { comunitários. }\end{array}$ & Norte do Pará \\
\hline $\begin{array}{l}\text { Mineração Caraíba } \\
\text { Unidade }\end{array}$ & Características & Regiões \\
\hline Pilar - Jaguarari & $\begin{array}{l}\text { Antiga, remota, isolada e confinada. Extração de cobre. } \\
\text { Criação da infra-estrutura da vila. }\end{array}$ & Norte da Bahia \\
\hline $\begin{array}{l}\text { Votorantim Metais } \\
\text { Unidades }\end{array}$ & Características & Regiões \\
\hline Niquelândia & $\begin{array}{l}\text { Antiga, remota, isolada e confinada. Extração de níquel } \\
\text { e cobalto. Criação da infra-estrutura da vila. }\end{array}$ & Norte de Goiás \\
\hline Três Marias & $\begin{array}{l}\text { Antiga, remota, semi-isolada e não confinada. Extração } \\
\text { de zinco. Criação da infra-estrutura da vila. }\end{array}$ & $\begin{array}{l}\text { Centro-Oeste de Minas } \\
\text { Gerais }\end{array}$ \\
\hline $\begin{array}{l}\text { PETROBRAS } \\
\text { Unidades }\end{array}$ & Características & Regiões \\
\hline UN Rio - Base Rio & Unidade antiga de suporte às Plataformas. & Sudeste \\
\hline UN Rio - Base Macaé & Unidade antiga de suporte às Plataformas. & Sudeste \\
\hline Plataforma P40 & $\begin{array}{l}\text { Antiga, remota, isolada e confinada. Extração de } \\
\text { petróleo. Criação da infra-estrutura da plataforma. }\end{array}$ & Sudeste \\
\hline Plataforma P38 & $\begin{array}{l}\text { Antiga, remota, isolada e confinada. Estocagem de } \\
\text { petróleo. Criação da infra-estrutura da plataforma. }\end{array}$ & Sudeste \\
\hline Plataforma P51 & $\begin{array}{l}\text { Nova, remota, isolada e confinada. Extração de petróleo. } \\
\text { Criação da infra-estrutura da plataforma. Ainda em } \\
\text { estaleiro. Foi visitada para observação. }\end{array}$ & Sudeste \\
\hline Plataforma PIV & $\begin{array}{l}\text { Antiga, móvel, remota, isolada e confinada. Perfuração } \\
\text { de poços. Criação da infra-estrutura da plataforma. }\end{array}$ & Sudeste \\
\hline UN Amazônia - Base Manaus & Unidade antiga de suporte à Base Urucu. & Norte \\
\hline UN Amazônia - Base Urucu & $\begin{array}{l}\text { Antiga. Extração de petróleo. Criação da infra-estrutura } \\
\text { na selva. }\end{array}$ & Norte \\
\hline
\end{tabular}


Assim, os níveis hierárquicos dos entrevistados obedeceram à seguinte ordem: diretoria ou gerência geral, gerência, coordenação, supervisão e RH (analista e consultor interno).

Esses níveis, não necessariamente foram preenchidos em todas as empresas/unidades remotas, também em razão da mencionada diferenciação da estrutura organizacional observada em cada uma dessas unidades pesquisadas.

O quadro $\mathrm{n}^{\mathrm{o}} .05$ apresenta o perfil dos entrevistados em todas elas. 


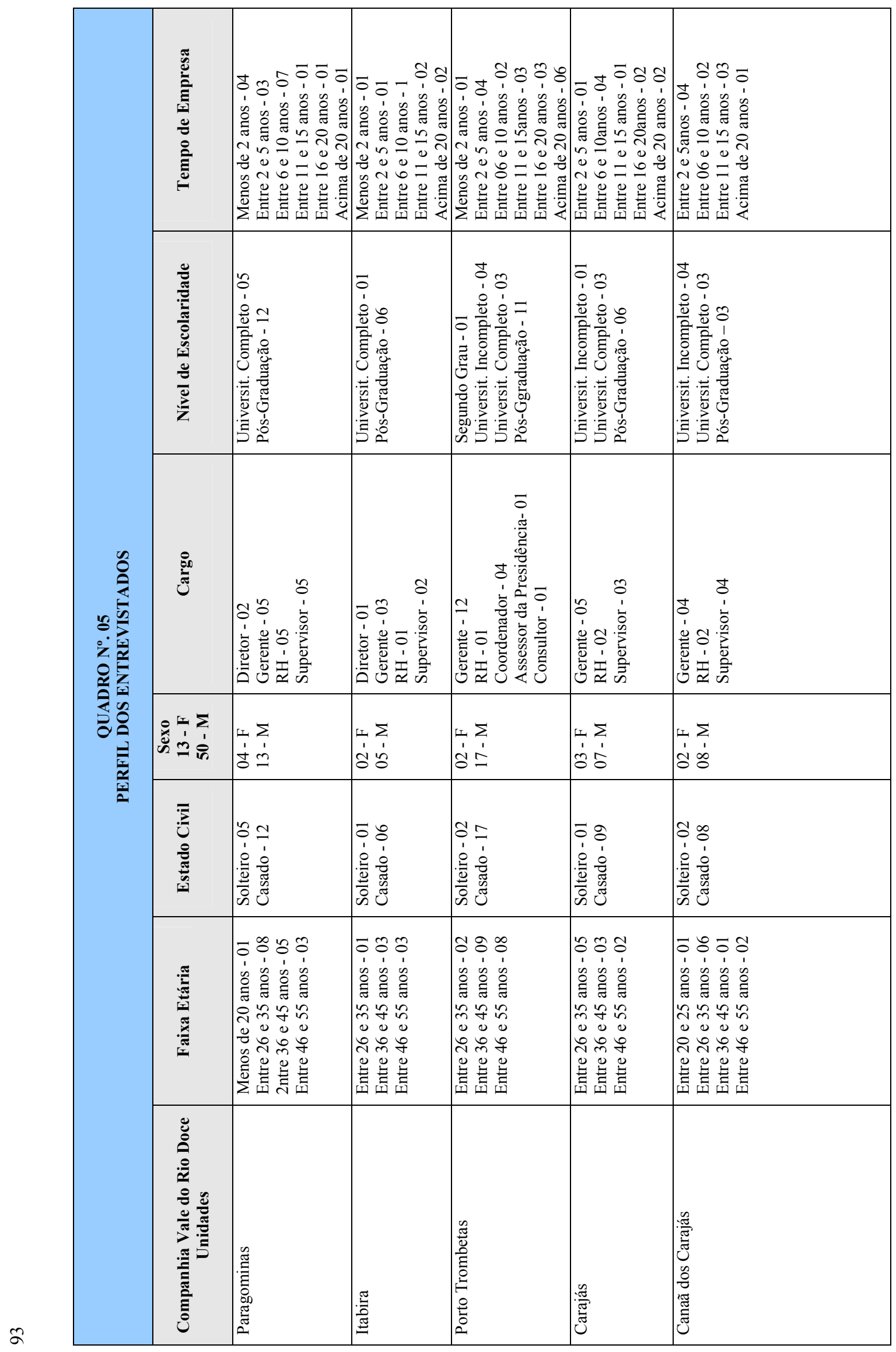




\begin{tabular}{|c|c|c|c|c|c|c|c|c|c|}
\hline 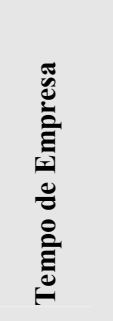 & 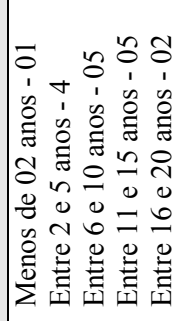 & 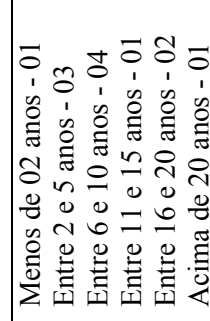 & 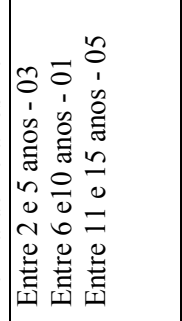 & 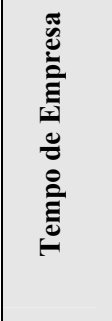 & 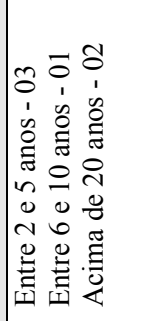 & 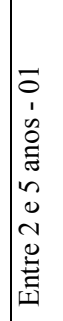 & 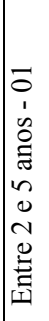 & 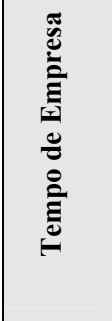 & 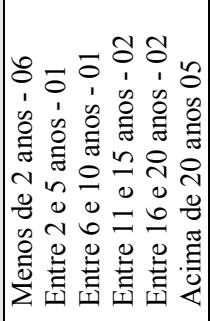 \\
\hline 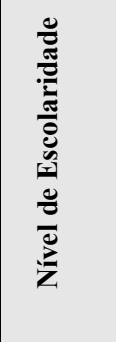 & 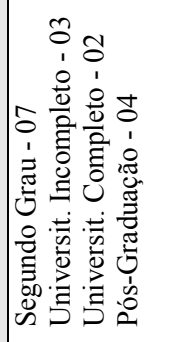 & 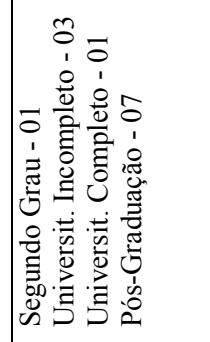 & 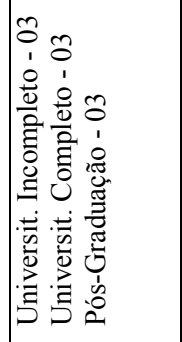 & 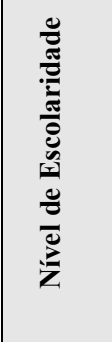 & 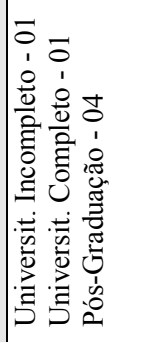 & 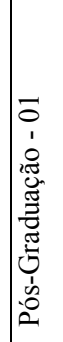 & 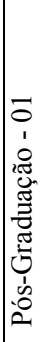 & 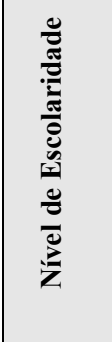 & 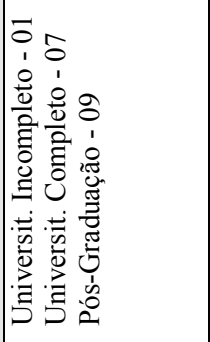 \\
\hline 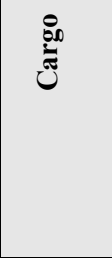 & 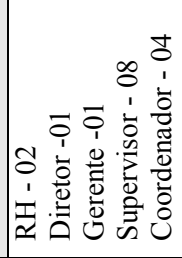 & 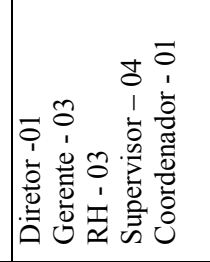 & 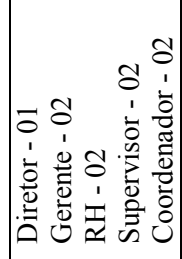 & 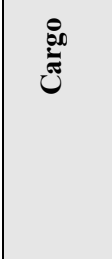 & 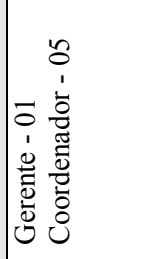 & $\begin{array}{l}\overrightarrow{0} \\
0 \\
\vdots \\
\overline{0} \\
\tilde{z} \\
\bar{z} \\
\overline{0} \\
0 \\
0\end{array}$ & 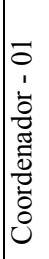 & שֶ. & 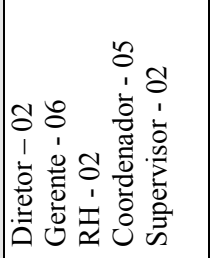 \\
\hline 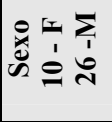 & 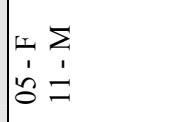 & $\begin{array}{ll}1 & \sum \\
1 & 1 \\
0 & 0\end{array}$ & $\begin{array}{ll}1 & \sum \\
1 & 1 \\
0 & 8\end{array}$ & 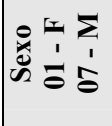 & $\begin{array}{l}\Sigma \\
1 \\
8\end{array}$ & $\begin{array}{l}\sum \\
1 \\
0\end{array}$ & $\begin{array}{l}1 \\
1 \\
0\end{array}$ & $\begin{array}{lll}0 & \sum \\
0 & 1 \\
0 & 1 & 1 \\
0 & 0 & 0\end{array}$ & $\begin{array}{ll}1 & 5 \\
1 & 1 \\
0 & 0 \\
0 & 0\end{array}$ \\
\hline 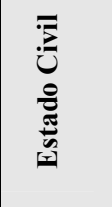 & 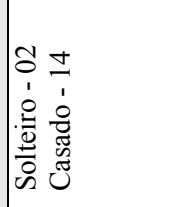 & 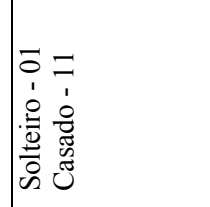 & 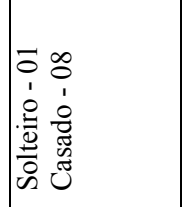 & 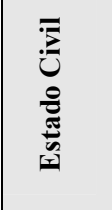 & 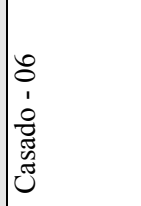 & $\begin{array}{l}\overrightarrow{0} \\
\dot{0} \\
\tilde{z} \\
\tilde{u} \\
\tilde{z} \\
\tilde{J}\end{array}$ & 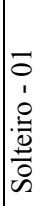 & 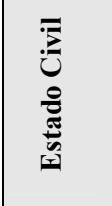 & 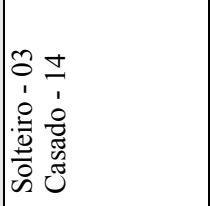 \\
\hline 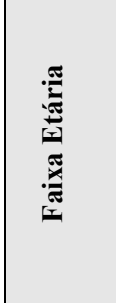 & 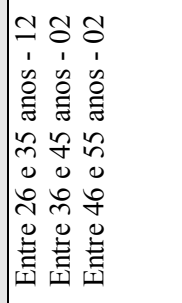 & $\begin{array}{lll}n & 0 & 0 \\
0 & 0 & 0 \\
1 & 1 & 1 \\
0 & 0 & 0 \\
0 & 0 & 0 \\
0 & 0 & 0 \\
0 & 0 & 0 \\
0 & 0 & n \\
0 & 0 & 0 \\
0 & 0 & 0 \\
0 & 0 & 0 \\
0 & 0 & 0 \\
0 & 0 & 0 \\
0 & 0 & 0 \\
1 & 1 & 1\end{array}$ & 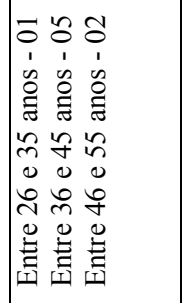 & 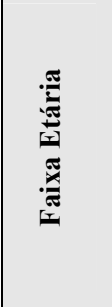 & 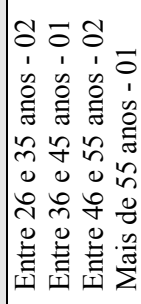 & 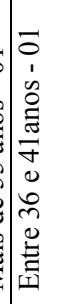 & 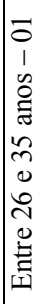 & 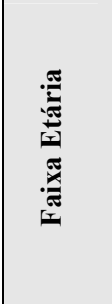 & 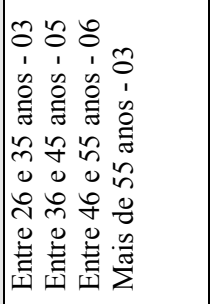 \\
\hline 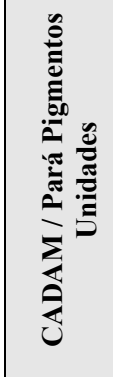 & 营 & 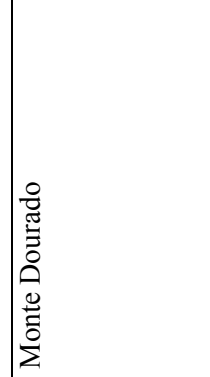 & $\mid$ & 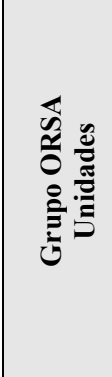 & 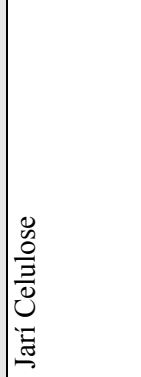 & 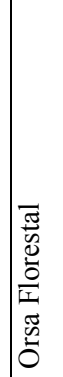 & 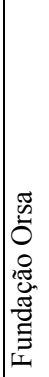 & 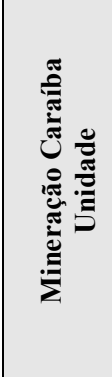 & 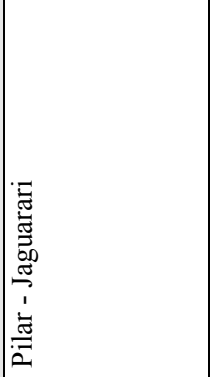 \\
\hline
\end{tabular}




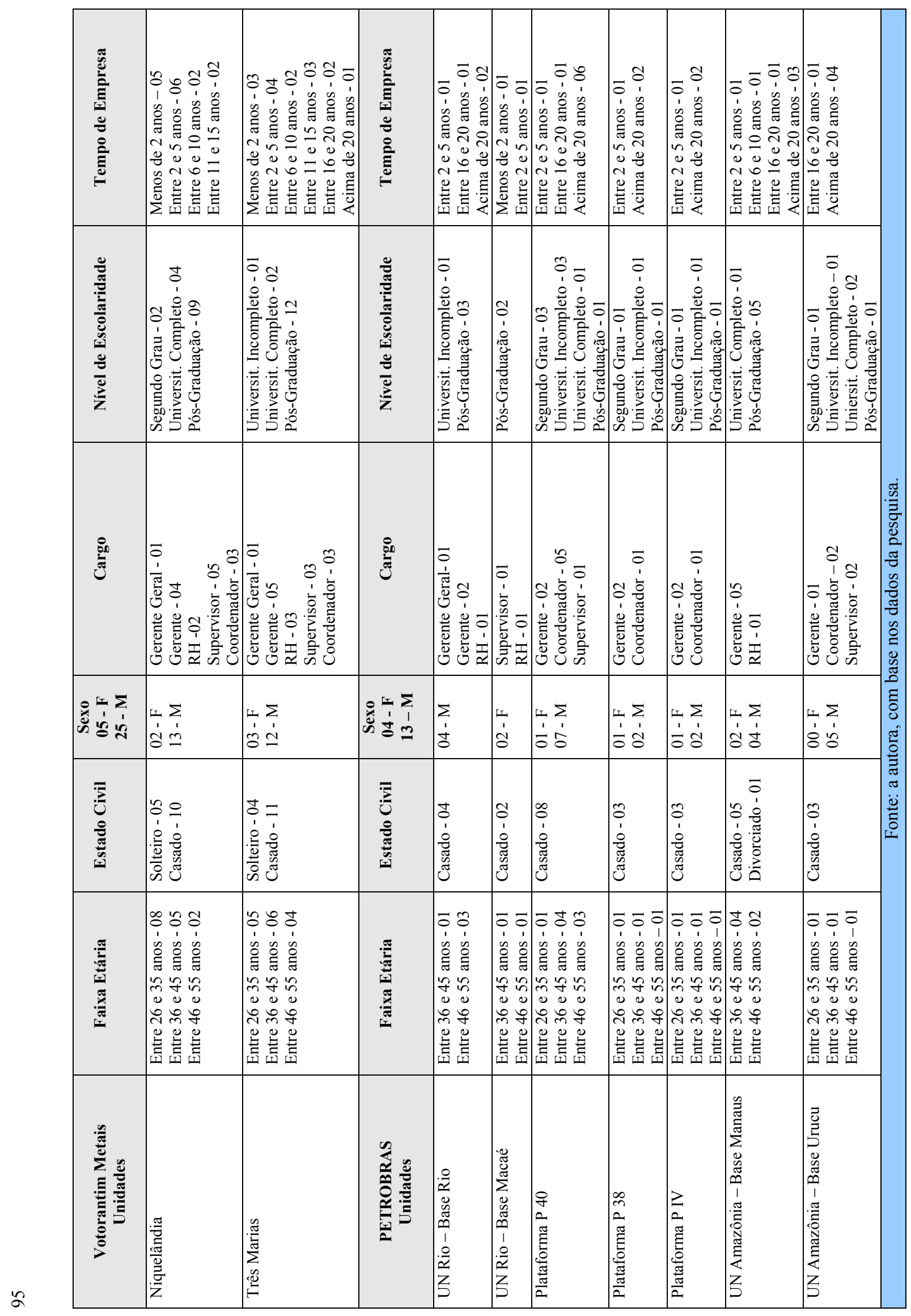




\section{1 Caso Companhia Vale do Rio Doce (Vale)}

A Companhia Vale do Rio Doce, recém denominada Vale, tem como visão "ser a maior empresa de mineração do mundo e superar os padrões consagrados de excelência em pesquisa, desenvolvimento, implantação de projetos e operação dos seus negócios." Sua missão é "transformar recursos minerais em riqueza e desenvolvimento sustentável” para seus acionistas, clientes, empregados, fornecedores, sociedades e países, dentre eles o Brasil.

Seus valores declarados são: "transparência e ética; excelência de desempenho; espírito desenvolvimentista; responsabilidade econômica, social e ambiental; respeito à vida; respeito à diversidade; orgulho de ser Vale." O último valor é considerado como o resultante de todos os outros.

As áreas remotas e inicialmente precárias constituem-se em características da Vale, inerentes à propria natureza do negócio de mineração. Os investimentos em criação e/ou adaptação da infra-estrtura necessária à operação, fazem parte do escopo dos projetos de cada unidade instalada nessas áreas remotas.

\section{1. 1 Unidade: Paragominas - Minério Bauxita}

A colonização do Município de Paragominas foi efetivada com camponeses pioneiros no final da década de 50, obteve autonomia em 1965 com a Lei no 3.235 de 4 de janeiro e, em 10 de maio de 1988, através da Lei ${ }^{0} 5.450$, teve sua área desmembrada para criação do Município de Dom Eliseu. A denominação Paragominas constitui a abreviação do nome de três Estados: Pará, Goiás e Minas Gerais.

A cidade vem recebendo uma significativa quantidade de imigrantes de outras regiões brasileiras impulsionados pela presença da Vale, trabalhando na extração de bauxita. A unidade de Paragominas, desde a fase de pesquisa de solo, em 2006, atraiu milhares de pessoas que buscavam oportunidades de emprego.

Paragominas é considerada uma unidade remota e não isolada, explora bauxita em mina a céu aberto. Não obstante as dificuldades, o seu acesso se dá por estrada de terra. A nova concepção dessa unidade remota envolve adaptações e melhorias da infra-estrutura existente 
na cidade, inserindo as residências dos funcionários na comunidade, com o intuito de promover a aproximação para o desenvolvimento conjunto das pessoas e da região. O quadro $n^{\circ} 6$, cuja composição foi detalhada na parte da apresentação e análise dos resultados, mostra a análise do conteúdo das dezessete entrevistas realizadas nessa unidade.

\begin{tabular}{|c|c|c|c|}
\hline \multicolumn{4}{|c|}{$\begin{array}{l}\text { QUADRO Nº. } 06 \\
\text { RESULTADO DA ANÁLISE DE CONTEÚDO DA UNIDADE PARAGOMINAS }\end{array}$} \\
\hline \multirow{2}{*}{$\begin{array}{l}\text { Unidade de Codificação } \\
\text { Palavras-tema }\end{array}$} & \multirow[t]{2}{*}{ Palavras-chave ou Frases-chave } & \multicolumn{2}{|c|}{ Contagem } \\
\hline & & Presença & Ausência \\
\hline 1. Feedback & $\begin{array}{l}\text { Estímulo; } \\
\text { Evidência. }\end{array}$ & $\begin{array}{l}16 \\
17\end{array}$ & $\begin{array}{c}01 \\
-\end{array}$ \\
\hline 2. Interações & Integrantes dos diversos escalões. & 17 & - \\
\hline 3. Abertura & $\begin{array}{l}\text { Encorajamento para debates; } \\
\text { Ocorrência de debates. }\end{array}$ & $\begin{array}{l}14 \\
17\end{array}$ & $\begin{array}{c}03 \\
-\end{array}$ \\
\hline 4. Comunicações interpessoais & Ocorrência entre as áreas. & 15 & 02 \\
\hline 5. Emoções & Expressão. & 13 & 04 \\
\hline 6. Pensar, sentir e agir & Evidência de interface. & 13 & 04 \\
\hline 7. Tomada de decisão & Ocorrência em grupo. & 15 & 02 \\
\hline 8. Comportamento intergrupal & Favorecendo o trabalho em equipe. & 16 & 01 \\
\hline 9. Participação & Estímulo à atitude de participação do empregado. & 15 & 02 \\
\hline 10. Envolvimento & $\begin{array}{l}\text { Estímulo à atitude de envolvimento do empregado } \\
\text { com os objetivos organizacionais. }\end{array}$ & 14 & 03 \\
\hline 11. Comprometimento & $\begin{array}{l}\text { Estímulo à atitude de comprometimento } \\
\text { (identificação) do empregado com os objetivos } \\
\text { organizacionais. }\end{array}$ & 17 & - \\
\hline 12. Expectativas & $\begin{array}{l}\text { Possibilidade de o empregado comunicar expecta- } \\
\text { tivas em relação à unidade; } \\
\text { Ocorrência de comunicação das expectativas da } \\
\text { unidade em relação ao empregado. }\end{array}$ & $\begin{array}{l}16 \\
16\end{array}$ & 01 \\
\hline 13. Responsabilidades & $\begin{array}{l}\text { Estímulo para o empregado assumir responsabili- } \\
\text { dades sobre suas ações. }\end{array}$ & 16 & 01 \\
\hline 14. Engajamento & $\begin{array}{l}\text { Estímulo ao engajamento das pessoas aos objetivos } \\
\text { e metas organizacionais. }\end{array}$ & 16 & 01 \\
\hline 15. Características da unidade & $\begin{array}{l}\text { Estimulando as pessoas a despenderem esforços } \\
\text { para nela permanecerem. }\end{array}$ & 16 & 01 \\
\hline 16. Cooperação & $\begin{array}{l}\text { Estímulo à atitude de cooperação; } \\
\text { Evidência da cooperação. }\end{array}$ & $\begin{array}{l}17 \\
17\end{array}$ & - \\
\hline 17. Valorização & $\begin{array}{l}\text { Evidência da valorização de opiniões e descobertas } \\
\text { em relação à maneira de se obter resultados; } \\
\text { Evidência da valorização do trabalho. }\end{array}$ & 13 & 04 \\
\hline 18. Aprendizagem/reaprendizagem & $\begin{array}{l}\text { Reconhecimento da necessidade de aprendiza- } \\
\text { gem/reaprendizagem em relação ao trabalho. }\end{array}$ & 16 & 01 \\
\hline 19. Desenvolvimento & $\begin{array}{l}\text { Demonstração do estímulo ao desenvolvimento } \\
\text { pessoal e profissional na própria organização. }\end{array}$ & 14 & 03 \\
\hline 20. Incentivos & $\begin{array}{l}\text { Disponibilização de incentivos vinculados a } \\
\text { resultados obtidos pela equipe. }\end{array}$ & 16 & 01 \\
\hline 21. Reconhecimento & $\begin{array}{l}\text { As pessoas são capazes de: desenvolvimento, } \\
\text { confiança e colaboração. }\end{array}$ & 17 & - \\
\hline $\begin{array}{l}\text { 22. Características organizacionais } \\
\text { da unidade }\end{array}$ & $\begin{array}{l}\text { Atrair e reter pessoas de alto potencial e } \\
\text { qualificação para o trabalho. }\end{array}$ & 12 & 05 \\
\hline $\begin{array}{l}\text { 23. Criação de condições de trabalho } \\
\text { na unidade }\end{array}$ & $\begin{array}{l}\text { Favoráveis à manutenção da motivação individual } \\
\text { para o trabalho; } \\
\text { Favoráveis à mobilização dos grupos em torno das } \\
\text { metas organizacionais. }\end{array}$ & $\begin{array}{l}12 \\
11\end{array}$ & 05 \\
\hline
\end{tabular}




\begin{tabular}{|c|c|c|c|}
\hline \multirow{2}{*}{$\begin{array}{l}\text { Unidade de Codificação } \\
\text { Palavras-tema }\end{array}$} & \multirow[t]{2}{*}{ Palavras-chave ou Frases-chave } & \multicolumn{2}{|c|}{ Contagem } \\
\hline & & Presença & Ausência \\
\hline $\begin{array}{l}\text { 24. Estrutura organizacional da } \\
\text { unidade }\end{array}$ & $\begin{array}{l}\text { Valorizando somente o que a liderança determina; } \\
\text { Valorizando a iniciativa individual; } \\
\text { Valorizando o poder concentrado na liderança; } \\
\text { Valorizando a responsabilidade compartilhada. }\end{array}$ & $\begin{array}{l}02 \\
09 \\
03 \\
14 \\
\end{array}$ & $\begin{array}{l}15 \\
08 \\
14 \\
03\end{array}$ \\
\hline 25. Comunicação & $\begin{array}{l}\text { Acerca do que é esperado do desempenho das } \\
\text { pessoas; } \\
\text { Dos acontecimentos críticos que marcam a história } \\
\text { da unidade; } \\
\text { Ocupação da unidade em saber como está sendo } \\
\text { percebido o seu processo de comunicação formal e } \\
\text { informal. }\end{array}$ & $\begin{array}{l}15 \\
15 \\
12\end{array}$ & $\begin{array}{l}02 \\
02 \\
05\end{array}$ \\
\hline 26. Missão organizacional & $\begin{array}{l}\text { Ocupação da unidade em saber como está sendo } \\
\text { compreendida sua missão. }\end{array}$ & 14 & 03 \\
\hline 27. Valores & $\begin{array}{l}\text { Demonstração dos valores pelos quais se rege a } \\
\text { unidade; } \\
\text { Comunicação e/ou constatação, pelos empregados, } \\
\text { da coerência entre os valores e o sistema de gestão } \\
\text { da unidade. }\end{array}$ & $\begin{array}{l}13 \\
14\end{array}$ & 04 \\
\hline 28. Políticas & $\begin{array}{l}\text { Criação das condições de adaptação de políticas } \\
\text { integradas de recursos humanos à realidade da } \\
\text { organização e ao seu contexto de atuação nessa } \\
\text { unidade remota. }\end{array}$ & 14 & 03 \\
\hline
\end{tabular}

As unidades de codificação 1 a 8 dizem respeito às palavras-tema contidas nos aspectos do comportamento organizacional A contagem de presenças expressivas mostra uma visão favorável dos entrevistados em relação a esses aspectos. Entretanto, as ausências contidas nas palavras-tema 5 e 6 não devem ser consideradas desprezíveis e podem ser conduzidas a um diálogo investigativo das razões.

As unidades de codificação 9 a 16 estão voltadas para as palavras-tema contidas nos aspectos do comprometimento organizacional. A contagem de presenças é quase totalitária em todas elas e denota a favorabilidade, na percepção dos entrevistados, com relação a esses aspectos, nessa unidade remota.

As unidades de codificação 17 a 23 referem-se às palavras-tema contidas nos aspectos de gestão estratégica de pessoas. As ausências observadas nas unidades de codificação 17 (frase-chave)1, 22, 23 (frases-chave 1 e 2) não podem ser desprezadas, na medida em que podem denotar visão desfavorável com relação a esses aspectos e constituem-se em oportunidades de investigação das razões dessas ausências. As presenças totalizadoras em algumas dessas unidades de codificação, 17 (frase-chave 2) e 21 e expressivas em outras, 17 (frase-chave 1),18, 19 e 20, atestam a visão favorável que os entrevistados têm dos aspectos da gestão de pessoas. 
As unidades de codificação 24 a 28 estão no bojo das palavras-tema contidas nos aspectos da cultura organizacional. Ressalte-se, nesse quadro, a ausência marcante da unidade de codificação 24 - estrutura organizacional dessa unidade remota, ausência essa representada pelas frases-chave "valorizando somente o que a liderança determina" e "valorizando o poder concentrado na liderança", o que pode denotar, conseqüentemente, a percepção dos entrevistados da ausência de estrutura rígida, inflexível e centralizadora. No que tange à frase-chave "valorizando a responsabilidade compartilhada" o resultado apresenta-se como confirmatório do significado da ausência mencionada. Ainda nessa unidade de codificação, no que diz respeito à frase-chave "valorizando a iniciativa individual", observe-se uma divisão na percepção dos entrevistados, denotandoespaço para buscar entender o significado.

As unidades de codificação 25 (frase-chave 3) e 27 (frase-chave 1), mostram ausências não desprezíveis. Essas mesmas unidades de codificação, em conjunto com as 26 e 28 apresentam visão favorável dos entrevistados nesses aspectos concernentes à cultura organizacional dessa unidade remota.

O quadro $n^{\circ} .7$, conforme foi explicitada a sua composição na parte de apresentação e análise dos resultados, apresenta o resultado da análise de conteúdo aplicadado ao escopo da pesquisa nessa unidade remota e contribui para aprofundar a compreensão do que foi mostrado no quadro $\mathrm{n}^{\circ} .6$.

\begin{tabular}{|c|c|c|}
\hline \multicolumn{3}{|c|}{$\begin{array}{l}\text { QUADRO No. } 07 \\
\text { RESULTADO DA ANÁLISE DE CONTEÚDO APLICADO AO ESCOPO DA PESQUISA } \\
\text { UNIDADE PARAGOMINAS }\end{array}$} \\
\hline $\begin{array}{c}\text { Categorias de } \\
\text { Análise }\end{array}$ & Temas Significativos & Unidade de Codificação \\
\hline $\begin{array}{c}\text { Comportamento } \\
\text { Organizacional }\end{array}$ & $\begin{array}{l}\text { Percepção da contri- } \\
\text { buição dos indivíduos, } \\
\text { dos grupos e da } \\
\text { estrutura. }\end{array}$ & $\begin{array}{l}\text { "A contribuição coletiva é mais visível e mais incentivada, as idéias } \\
\text { que vêm dos indivíduos são capitalizadas na equipe e os créditos são } \\
\text { dados aos indivíduos." } \\
\text { "A estrutura contribui para os resultados obtidos pelos indivíduos, na } \\
\text { medida em que os gestores trabalham em pares." } \\
\text { "A estrutura remota favorece a busca de contribuição, desde a } \\
\text { adaptação das pessoas à região, até o ganho coletivo como os } \\
\text { resultados da unidade." } \\
\text { "A estrutura aproxima (diretores, gerentes, supervisores e operadores). } \\
\text { Todos são ouvidos e isso contribui." }\end{array}$ \\
\hline
\end{tabular}




\begin{tabular}{|c|c|c|}
\hline $\begin{array}{c}\text { Categorias de } \\
\text { Análise }\end{array}$ & Temas Significativos & Unidade de Codificação \\
\hline $\begin{array}{c}\text { Comprometimento } \\
\text { Organizacional }\end{array}$ & $\begin{array}{l}\text { Percepção do orgulho e } \\
\text { do empenho exercido } \\
\text { pelos indivíduos em } \\
\text { favor dessa unidade } \\
\text { remota. }\end{array}$ & $\begin{array}{l}\text { "Pelo fato de ser uma unidade nova e já começar com muita gente } \\
\text { jovem, a própria equipe de veteranos da companhia tem a } \\
\text { oportunidade de aperceber-se e demonstrar o orgulho e o empenho } \\
\text { conjunto no amadurecimento do projeto." } \\
\text { "Há muito comprometimento de todos os antigos em formar a turma. } \\
\text { As pessoas que vieram de outras unidades têm todo o empenho para } \\
\text { fazer acontecer o crescimento da unidade." } \\
\text { "Os aprendizes entram muito motivados e o orgulho é demonstrado } \\
\text { pelo fato de entrarem na vida profissional por intermédio da VALE." } \\
\text { "Aqui, prioritariamente a companhia abriu as portas para o trabalho } \\
\text { com as pessoas da região. Esse desafio é devolvido com o empenho e } \\
\text { o orgulho demonstrados pelo brilho dos olhos das pessoas, ao falarem } \\
\text { do seu trabalho." } \\
\text { "As pessoas são comprometidas, com paixão pelo que fazem e geram } \\
\text { resultados cada vez melhores e maiores em prol da unidade. Ter } \\
\text { orgulho em trabalhar aqui tem sido um diferencial." } \\
\text { "Por ser oferecido um clima de trabalho propício ao desenvolvimento } \\
\text { dos talentos, as pessoas demonstram continuamente o seu empenho } \\
\text { nas atividades diárias." }\end{array}$ \\
\hline $\begin{array}{c}\text { Gestão Estratégica } \\
\text { de Pessoas }\end{array}$ & $\begin{array}{l}\text { Percepção da adoção de } \\
\text { novas práticas de } \\
\text { gestão, de modo a } \\
\text { facilitar as ações de } \\
\text { desenvolvimento e e } \\
\text { resolução de conflitos } \\
\text { nessa unidade. }\end{array}$ & $\begin{array}{l}\text { "O programa de aprendizes na unidade a enche de juventude e vida." } \\
\text { "A valorização dos empregados e as políticas de gestão de pessoas da } \\
\text { Vale favorecem o comprometimento." } \\
\text { "A unidade tem a liberdade de lidar com as suas especificidades." } \\
\text { "Os gestores são os principais responsáveis no trato dos conflitos." } \\
\text { "Os gestores facilitam o diálogo e estimulam o seu exercício } \\
\text { permanente." }\end{array}$ \\
\hline $\begin{array}{c}\text { Cultura } \\
\text { Organizacional }\end{array}$ & $\begin{array}{l}\text { Percepção do conhe- } \\
\text { cimento que os indi- } \\
\text { víduos têm, acerca da } \\
\text { visão, filosofia de } \\
\text { atuação, missão e va- } \\
\text { lores nessa unidade. }\end{array}$ & $\begin{array}{l}\text { "Todos entendem os valores, principalmente segurança e meio- } \\
\text { ambiente." } \\
\text { "A autoridade para deixar de fazer uma atividade que prejudique o } \\
\text { meio-ambiente, a saúde e a segurança é compreendida e utilizada por } \\
\text { todos os escalões." } \\
\text { "Precisa ser trabalhada a cultura local. A cidade Paragominas tem uma } \\
\text { história diferente com relação ao meio-ambiente e a Vale tem papel } \\
\text { importante na reeducação ambiental." } \\
\text { "A integração entre a empresa e a comunidade é um ponto que vem } \\
\text { sendo tratado com cuidado." } \\
\text { "O processo de lembrar a visão, a missão, os valores e a filosofia de } \\
\text { atuação da unidade é diário." }\end{array}$ \\
\hline
\end{tabular}

A unidade Paragominas é nova, bem como seus integrantes, cuja média de idade é 25 anos. Depreende-se que nessa unidade, com núcleos de moradia mais integrados com a comunidade, a contribuição vai além dos resultados operacionais, incorporando os resultados que são obtidos por meio de integração com a comunidade e com os funcionários de todas as 
áreas. Ficou evidenciado nas entrevistas que as pessoas com dificuldades de conviver com estruturas remotas se desligam rapidamente.

A questão como a gestão de pessoas facilita ou dificulta a obtenção do comprometimento organizacional nessa unidade remota passa a ser respondida nos parágrafos subseqüentes.

As diretrizes macro vêm da corporação. A unidade tem a liberdade de lidar com as suas especificidades, sem prejuízo da forma de apreender essas diretrizes. A VALER Universidade Corporativa - cuida das ações de desenvolvimento, auxiliada pela área de Gestão de Pessoas.

Essas ações de desenvolvimento se traduzem nas atividades de treinamentos (teórico e prático) e no papel de reeducar, encontrado no bojo das atividades dos gestores: repassando todos os valores da Companhia no seu dia-a-dia; facilitando o equilíbrio entre trabalho, família, educação e saúde; construindo uma cultura de humanização da unidade; inserindo valorização, consideração, felicidade e realização às atividades diárias.

As ações de resolução de conflitos são tratadas como incumbências dos gestores, os quais estabelecem como critérios principais os valores de abertura e transparência no trato das questões, o que tem acarretado, na opinião dos entrevistados, clima de confiança e comprometimento contínuo.

O sentimento de orgulho por pertencer à Vale, em Paragominas, tem o seu reflexo na participação e na aprovação do acordo coletivo de trabalho. $\mathrm{Na}$ pesquisa de clima da Companhia a unidade ficou entre as primeiras colocadas, de acordo com o depoimento dos entrevistados. Os diálogos, as decisões compartilhadas, o estímulo ao trabalho em equipe, a celebração de marcos importantes e os ajustes realizados com tranqüilidade e abertura são os responsáveis por esse resultado, na opinião desses entrevistados.

O orgulho é considerado incontestável pelos entrevistados. Eles salientam que a unidade Paragominas trouxe uma perspectiva muito grande para o município, transformando-se em principal desafio para os gestores ajudarem os jovens a manter o equilíbrio necessário para a criação da cultura da unidade, voltada para um clima de trabalho propício ao desenvolvimento dos talentos das pessoas com segurança e responsabilidade. 
O processo de lembrar os valores que compõem a cultura da unidade, assim como a visão, a missão, e a filosofia de atuação, é diário, por meio das reuniões de passagem dos turnos. Tal processo deve-se ao fato de Paragominas ser uma cidade já existente, há quarenta e dois anos antes da implantação dessa unidade remota e, a cultura predominante de extração de madeira a qualquer custo não estar em linha com os valores da Companhia, principalmente os de segurança, meio-ambiente e saúde. Ficou enfatizado que esse processo é reforçado nas reuniões semanais e mensais, salientando os componentes da cultura da unidade, os quais envolvem transparência, abertura, compromisso com a saúde, a segurança, o meio-ambiente e o respeito às individualidades.

A questão de pesquisa que investiga a existência de diferenças entre as culturas das unidades remotas, e como essas diferenças se evidenciam é respondida nessa unidade com o programa de aprendizes envolvendo jovens nascidos em Paragominas como uma prática de desenvolvimento das pessoas e aproximação com a comunidade específica da unidade.

Essa ação visa propiciar a retenção de talentos em todos os níveis no futuro da unidade, pois, além do programa de aprendizes há uma prática de colocar o líder como ‘dono do negócio' e isso tem mantido o estímulo para a troca de conhecimento na formação profissional, na prática. Para tanto, a carreira de sucessões é uma ação de desenvolvimento, na qual as pessoas treinam e são treinadas simultaneamente. $\mathrm{O}$ contingente contratado pela Vale na região é alto e, igualmente alto, o de novos aprendizes. A remuneração diferenciada gera possibilidade de aquisição de casa própria, melhoria da saúde e estabilidade da família. A remuneração variável é considerada competitiva e privilegiada. A oportunidade de a unidade contribuir com a região foi ressaltada pelos entrevistados.

Esses entrevistados enfatizam que esse programa vem contribuindo para mudanças no nível de consciência da população e para a oportunidade de alocação de mão-de-obra da própria região na operação da unidade remota. O elo percebido na construção dessa contribuição visa ligar empresa, família, sociedade e utizar os valores segurança, meio-ambiente, respeito e visão social.

Reforce-se que os dados da pesquisa, nessa unidade, mostram chefias e colegas de todas as áreas e/ou da mesma área estimulando: feedbacks, debates, engajamento, cooperação, valorização do trabalho, reconhecimento pela capacidade de desenvolvimento, confiabilidade e colaboração. A valorização dos empregados e as políticas de gestão da Vale favorecem o 
comprometimento dentro da unidade, uma vez que as pessoas percebem as políticas de Gestão à Vista, em sua veracidade e relevância. Nesse ponto dá-se o cruzamento dos aspectos ligados a comportamento, comprometimento, gestão de pessoas e cultura organizacional, detalhados no quadro $n^{0} .06$.

\section{1. 2 Unidade: Itabira - Minério Ferro - Minas Conceição e Cauê}

Itabira é uma cidade e município brasileiro do Estado de Minas Gerais. No aspecto econômico tinha seu progresso garantido pelas indústrias de fundição de ferro, que existiam desde o final do Império. É conhecida também por Cidade do Ferro, já que foi palco da criação da Companhia Vale do Rio Doce em 1942, considerada a segunda maior mineradora do mundo.

Com a criação da Companhia e a exploração do minério em grande escala, a cidade de fato começou a crescer e a se desenvolver economicamente. Foram encampadas, em sua criação, a Companhia Brasileira de Mineração e Siderurgia, a Companhia Itabira de Mineração e a Companhia de Estrada de Ferro Vitória-Minas. A Vale reformulou e mais tarde duplicou a Estrada de Ferro Vitória-Minas, destinada ao transporte de minério até o Porto de Tubarão, no Espírito Santo. Nos dias atuais, Itabira é considerada uma unidade remota e não isolada. O seu acesso se dá por estrada asfaltada e perigosa por ser sinuosa. O Aeroporto mais próximo da cidade é o Aeroporto Internacional Tancredo Neves (Confins), que serve também Belo Horizonte e grande parte da região. A concepção dessa unidade remota envolveu a criação da cidade, uma vez que existia apenas o povoado.

No final da década de 1960, Itabira ganhou novo impulso em seu desenvolvimento com o plano de expansão da Vale, que construiu e colocou em operação o Projeto Cauê, responsável por uma explosão econômica e cultural da cidade. A mina Cauê foi a primeira unidade de concentração de minério de ferro do mundo e trazia a cultura alemã. A mina Conceição é um projeto melhorado com equipamentos de maior capacidade e traz mais traços da cultura brasileira. A unidade explora o minério de ferro em mina subterrânea.

Com o crescimento da cidade, aos poucos a Companhia foi deixando o seu controle para a própria comunidade. Atualmente Itabira é uma cidade autônoma, com maior facilidade de deslocamentos para Belo Horizonte. O quadro $\mathrm{n}^{\circ} .8$ mostra o resultado da análise de conteúdo das sete entrevistas realizadas nessa unidade. 


\begin{tabular}{|c|c|c|c|}
\hline \multicolumn{4}{|c|}{$\begin{array}{l}\text { QUADRO No }{ }^{\circ} 08 \\
\text { RESULTADO DA ANÁLISE DE CONTEÚDO DA UNIDADE ITABIRA }\end{array}$} \\
\hline \multirow{2}{*}{$\begin{array}{l}\text { Unidade de Codificação } \\
\text { Palavras-tema }\end{array}$} & \multirow[t]{2}{*}{ Palavras-chave ou Frases-chave } & \multicolumn{2}{|c|}{ Contagem } \\
\hline & & Presença & Ausência \\
\hline 1. Feedback & $\begin{array}{l}\text { Estímulo; } \\
\text { Evidência. }\end{array}$ & $\begin{array}{l}07 \\
07\end{array}$ & - \\
\hline 2. Interações & Integrantes dos diversos escalões. & 06 & 01 \\
\hline 3. Abertura & $\begin{array}{l}\text { Encorajamento para debates; } \\
\text { Ocorrência de debates. }\end{array}$ & $\begin{array}{l}07 \\
07\end{array}$ & $\begin{array}{l}- \\
-\end{array}$ \\
\hline 4. Comunicações interpessoais & Ocorrência entre as áreas. & 04 & 03 \\
\hline 5. Emoções & Expressão. & 06 & 01 \\
\hline 6. Pensar, sentir e agir & Evidência de interface. & 05 & 02 \\
\hline 7. Tomada de decisão & Ocorrência de em grupo. & 06 & 01 \\
\hline 8. Comportamento intergrupal & Favorecendo o trabalho em equipe. & 07 & - \\
\hline 9. Participação & Estímulo à atitude de participação do empregado. & 06 & 01 \\
\hline 10. Envolvimento & $\begin{array}{l}\text { Estímulo à atitude de envolvimento do empregado } \\
\text { com os objetivos organizacionais. }\end{array}$ & 07 & - \\
\hline 11. Comprometimento & $\begin{array}{l}\text { Estímulo à atitude de comprometimento } \\
\text { (identificação) do empregado com os objetivos } \\
\text { organizacionais. }\end{array}$ & 06 & 01 \\
\hline 12. Expectativas & $\begin{array}{l}\text { Possibilidade de o empregado comunicar expecta- } \\
\text { tivas em relação à unidade. } \\
\text { Ocorrência de comunicação das expectativas da } \\
\text { unidade em relação ao empregado. }\end{array}$ & $\begin{array}{l}07 \\
04\end{array}$ & 03 \\
\hline 13. Responsabilidades & $\begin{array}{l}\text { Estímulo para o empregado assumir responsabili- } \\
\text { dades sobre suas ações. }\end{array}$ & 07 & - \\
\hline 14. Engajamento & $\begin{array}{l}\text { Estímulo ao engajamento das pessoas aos objetivos } \\
\text { e metas organizacionais. }\end{array}$ & 07 & - \\
\hline 15. Características da unidade & $\begin{array}{l}\text { Estimulando as pessoas a despenderem esforços } \\
\text { para nela permanecerem. }\end{array}$ & 07 & - \\
\hline 16. Cooperação & $\begin{array}{l}\text { Estímulo à atitude de cooperação; } \\
\text { Evidência da cooperação. }\end{array}$ & $\begin{array}{l}07 \\
07\end{array}$ & $\begin{array}{l}- \\
-\end{array}$ \\
\hline 17. Valorização & $\begin{array}{l}\text { Evidência da valorização de descobertas em relação } \\
\text { à maneira de se obter resultados; } \\
\text { Evidência da valorização do trabalho. }\end{array}$ & $\begin{array}{l}06 \\
07 \\
\end{array}$ & $\begin{array}{l}01 \\
- \\
\end{array}$ \\
\hline 18. Aprendizagem/reaprendizagem & $\begin{array}{l}\text { Reconhecimento da necessidade de aprendiza- } \\
\text { gem/reaprendizagem em relação ao trabalho. }\end{array}$ & 06 & 01 \\
\hline 19. Desenvolvimento & $\begin{array}{l}\text { Demonstração do estímulo ao desenvolvimento } \\
\text { pessoal e profissional na organização. }\end{array}$ & 06 & 01 \\
\hline 20. Incentivos & $\begin{array}{l}\text { Disponibilização de incentivos vinculados a } \\
\text { resultados obtidos pela equipe. }\end{array}$ & 06 & 01 \\
\hline 21. Reconhecimento & $\begin{array}{l}\text { As pessoas são capazes de: desenvolvimento, } \\
\text { confiança e colaboração. }\end{array}$ & 07 & - \\
\hline $\begin{array}{l}\text { 22. Características organizacionais } \\
\text { da unidade }\end{array}$ & $\begin{array}{l}\text { Atrair e reter pessoas de alto potencial e qualifica- } \\
\text { ção para o trabalho. }\end{array}$ & 05 & 02 \\
\hline $\begin{array}{l}\text { 23. Criação de condições de trabalho } \\
\text { na unidade }\end{array}$ & $\begin{array}{l}\text { Favoráveis à manutenção da motivação individual } \\
\text { para o trabalho; } \\
\text { Favoráveis à mobilização dos grupos em torno das } \\
\text { metas organizacionais. }\end{array}$ & $\begin{array}{l}06 \\
07\end{array}$ & 01 \\
\hline $\begin{array}{l}\text { 24. Estrutura organizacional da } \\
\text { unidade }\end{array}$ & $\begin{array}{l}\text { Valorizando somente o que a liderança determina; } \\
\text { Valorizando a iniciativa individual; } \\
\text { Valorizando o poder concentrado na liderança; } \\
\text { Valorizando a responsabilidade compartilhada. }\end{array}$ & $\begin{array}{l}- \\
05 \\
04 \\
05\end{array}$ & $\begin{array}{l}07 \\
02 \\
03 \\
02\end{array}$ \\
\hline 25. Comunicação & $\begin{array}{l}\text { Acerca do que é esperado do desempenho das } \\
\text { pessoas; } \\
\text { Dos acontecimentos críticos que marcam a história } \\
\text { da unidade; } \\
\text { Ocupação da unidade em saber como está sendo } \\
\text { percebido o seu processo de comunicação formal e } \\
\text { informal. }\end{array}$ & $\begin{array}{l}05 \\
07 \\
05\end{array}$ & $\begin{array}{c}02 \\
- \\
02\end{array}$ \\
\hline 26. Missão organizacional & $\begin{array}{l}\text { Ocupação da unidade em saber como está sendo } \\
\text { compreendida sua missão. }\end{array}$ & 05 & 02 \\
\hline
\end{tabular}




\begin{tabular}{|l|l|c|c|}
\hline \multirow{2}{*}{$\begin{array}{c}\text { Unidade de Codificação } \\
\text { Palavras-tema }\end{array}$} & \multicolumn{1}{|c|}{ Palavras-chave ou Frases-chave } & \multicolumn{2}{c|}{ Contagem } \\
\cline { 2 - 4 } & $\begin{array}{l}\text { Presença } \\
\text { 27. Valores }\end{array}$ & $\begin{array}{l}\text { Ausência } \\
\text { unidade; } \\
\text { Comunicação e/ou constatação, pelos empregados, } \\
\text { da coerência entre os valores e o sistema de gestão } \\
\text { da unidade. }\end{array}$ & 05 \\
\hline 28. Políticas & $\begin{array}{l}\text { Criação das condições de adaptação de políticas } \\
\text { integradas de recursos humanos à realidade da } \\
\text { organização e ao seu contexto de atuação nessa } \\
\text { unidade remota. }\end{array}$ & 02 \\
\hline \multicolumn{2}{|l}{ Fonte: a autora, com base nos dados da pesquisa. } \\
\hline
\end{tabular}

As unidades de codificação 1 a 8 dizem respeito às palavras-tema contidas nos aspectos do comportamento organizacional A contagem de presenças totalitárias nas unidades de codificação 1 (ambas as palavras-chave) e 3 (ambas as frases-chave), seguida de presenças expressivas nas unidades 2, 5, 7, 9 e 6 mostra uma visão favorável dos entrevistados em relação aos aspectos ligados ao comportamento organizacional. Contudo, as ausências contidas nas palavras-tema 4 (com divisão quase eqüitativa entre presenças e ausências) e 6, não devem ser consideradas desprezíveis e podem ser conduzidas a um diálogo investigativo das razões.

As unidades de codificação 9 a 16 estão voltadas para as palavras-tema contidas nos aspectos do comprometimento organizacional. A contagem de presenças é quase totalitária em todas elas e denota a favorabilidade, na percepção dos entrevistados, com relação a esses aspectos. Todavia, a unidade de codificação 12, em sua frase-chave 2 , mostra que as ausências já convidam ao diálogo das razões que estão nelas embutidas.

As unidades de codificação 17 a 23 referem-se às palavras-tema contidas nos aspectos de gestão estratégica de pessoas. As presenças totalizadoras em algumas dessas unidades de codificação e expressivas em outras, reforçadas por suas respectivas frases-chave, atestam a visão favorável que os entrevistados têm dos aspectos da gestão de pessoas. As ausências observadas na unidade de codificação 22 não podem ser desprezadas, uma vez que se constituem em oportunidades de investigação das razões dessas ausências.

As unidades de codificação 24 a 28 estão no bojo das palavras-tema contidas nos aspectos da cultura organizacional. Saliente-se, nesse quadro, a ausência total da unidade de codificação 24 - estrutura organizacional da unidade, representada pela frase-chave "valorizando somente o que a liderança determina". No que tange às frases-chave "valorizando a responsabilidade 
compartilhada" e "valorizando a iniciativa individual" os resultados mostram-se representativos para a confirmação do significado da ausência de rigidez e centralização nas determinações da liderança. Ainda nessa mesma unidade de codificação, no que diz respeito à frase-chave "valorizando o poder concentrado na liderança", observe-se quase uma divisão na percepção dos entrevistados, o que não se mostra congruente com o que foi respondido na primeira frasechave dessa unidade de codificação e confirmado pelas outras.

As unidades de codificação 25 (frases-chave 1 e 3), 26 e 27 (frases-chave 1 e 2), mostram ausências não desprezíveis. Essas mesmas unidades, entretanto, apresentam visão favorável dos entrevistados nesses aspectos concernentes à cultura da unidade remota. A unidade de codificação 28 apresenta uma divisão quase que eqüitativa entre presenças e ausências. É importante serem conhecidas e discutidas as razões.

O quadro $\mathrm{n}^{\circ} .9$ apresenta o resultado da análise de conteúdo aplicadado ao escopo da pesquisa nessa unidade remota pesquisada e contribui para aprofundar a compreensão do que foi mostrado no quadro $n^{\circ} .8$.

\begin{tabular}{|c|c|c|}
\hline \multicolumn{3}{|c|}{$\begin{array}{c}\text { QUADRO No. } 09 \\
\text { RESULTADO DA ANÁLISE DE CONTEÚDO APLICADO AO ESCOPO DA PESQUISA UNIDADE ITABIRA }\end{array}$} \\
\hline $\begin{array}{l}\text { Categorias de } \\
\text { Análise }\end{array}$ & Temas Significativos & Unidade de Codificação \\
\hline $\begin{array}{l}\text { Comportamento } \\
\text { Organizacional }\end{array}$ & $\begin{array}{l}\text { Percepção da contri- } \\
\text { buição dos indivíduos, } \\
\text { dos grupos e da } \\
\text { estrutura. }\end{array}$ & $\begin{array}{l}\text { "Reuniões de feedback mostram para nós que atingir metas é } \\
\text { conseqüência. O objetivo central é o empregado." } \\
\text { "O foco no trabalho com solidariedade é perseguido continuamente." } \\
\text { "A estrutura remota e, relativamente próxima nos dias atuais, oferece } \\
\text { mais vantagens para que as pessoas se retenham na unidade." } \\
\text { "As pessoas podem participar dos rumos da organização dentro da } \\
\text { unidade e isso as estimula a contribuir perenemente." }\end{array}$ \\
\hline $\begin{array}{l}\text { Comprometimento } \\
\text { Organizacional }\end{array}$ & $\begin{array}{l}\text { Percepção do orgulho e } \\
\text { do empenho exercido } \\
\text { pelos indivíduos em } \\
\text { favor dessa unidade } \\
\text { remota. }\end{array}$ & $\begin{array}{l}\text { "Temos o orgulho como um valor, pois nos orgulhamos de ser VALE } \\
\text { quando sabemos que estamos construindo algo que fará a diferença." } \\
\text { "Todos os gestores aqui são competentes e comprometidos com a } \\
\text { melhoria na integração entre as áreas. O comprometimento das } \\
\text { pessoas de todos os escalões atesta isso." } \\
\text { "As pessoas criaram a companhia e elas têm muito orgulho. O orgulho } \\
\text { e o empenho estão muito entrelaçados." } \\
\text { "As pessoas não trabalham aqui pensando em sair. Elas pensam em } \\
\text { melhorar aqui dentro." } \\
\text { "Na última pesquisa de clima o orgulho foi o item mais forte. As } \\
\text { pessoas trabalham com brilho nos olhos e o empenho é percebido nos } \\
\text { resultados que elas geram." }\end{array}$ \\
\hline
\end{tabular}




\begin{tabular}{|c|c|c|}
\hline $\begin{array}{l}\text { Categorias de } \\
\text { Análise }\end{array}$ & Temas Significativos & Unidade de Codificação \\
\hline $\begin{array}{c}\text { Gestão Estratégica } \\
\text { de Pessoas }\end{array}$ & $\begin{array}{l}\text { Percepção da adoção de } \\
\text { novas práticas de } \\
\text { gestão, de modo a } \\
\text { facilitar as ações de } \\
\text { desenvolvimento e } \\
\text { resolução de conflitos } \\
\text { nessa unidade. }\end{array}$ & $\begin{array}{l}\text { "A orientação básica vem de um RH corporativo, mas o que é } \\
\text { específico os gestores têm autonomia para incrementar. O perfil aqui é } \\
\text { muito mais voltado para as pessoas" } \\
\text { "A maior facilidade de acesso a Belo Horizonte, na atualidade, tem } \\
\text { ajudado muito nas ações de desenvolvimento." } \\
\text { "A facilitação na resolução de conflitos na unidade está ligada à } \\
\text { autonomia dos gestores." } \\
\text { "As pessoas são estimuladas ao desenvolvimento de carreira e não há } \\
\text { registro de queda de produtividade dos indivíduos ou grupos que se } \\
\text { deslocam para estudar." } \\
\text { "A prática diária tem sido trabalhada na comunicação diária. A } \\
\text { interdependência tem sido o caminho." }\end{array}$ \\
\hline $\begin{array}{c}\text { Cultura } \\
\text { Organizacional }\end{array}$ & $\begin{array}{l}\text { Percepção do conhe- } \\
\text { cimento que os indi- } \\
\text { víduos têm, acerca da } \\
\text { visão, filosofia de } \\
\text { atuação, missão e } \\
\text { valores nessa unidade } \\
\text { remota. }\end{array}$ & $\begin{array}{l}\text { "Como as pessoas criaram a organização elas conhecem e } \\
\text { compreendem as suas fases. A unidade busca imprimir clareza e } \\
\text { transparência com relação a: visão, filosofia de atuação, missão e } \\
\text { valores." } \\
\text { "A cultura do respeito é que desenvolve, trata os conflitos e } \\
\text { amadurece as pessoas. Os resultados numéricos continuam, mas não a } \\
\text { qualquer custo." } \\
\text { "É preciso confiar nas pessoas, em suas competências e habilidades. A } \\
\text { perspectiva de que a perfeição é igual a ambiente saudável, de modo } \\
\text { que as pessoas tenham vontade de voltar no dia seguinte é o que nos } \\
\text { fortalece." } \\
\text { "É preciso confiar nas pessoas, nas suas competências e habilidades." }\end{array}$ \\
\hline \multicolumn{3}{|c|}{ Fonte: a autora, com base nos dados da pesquisa. } \\
\hline
\end{tabular}

A unidade Itabira é antiga, mas seus integrantes têm em média doze anos de unidade. No passado, essa unidade era composta pela Vila de Engenheiros, afastada. Hoje, a cidade propicia maior aproximação.

A evolução é percebida pelos entrevistados como clara, saindo da prática paternalista para uma relação mais madura, autônoma e bilateral com a comunidade. Todos afirmam que a cidade de Itabira era 100\% dependente da Companhia. Atualmente, esse percentual é de $80 \%$. As pessoas passaram a enxergar a vida fora da Companhia, na visão desses entrevistados.

A questão de pesquisa que investiga a existência de diferenças entre as culturas das unidades remotas, quais são essas diferenças e como elas se evidenciam é respondida nessa unidade com a ênfase dada pelos entrevistados ao diálogo com a comunidade mantido pela Companhia, que promove programas de aproximação com as pessoas, a exemplo do projeto de parceria para instalação de uma unidade de ensino da Universidade Federal, com a 
perspectiva de completar o ciclo educacional em graduação e pós-graduação, de modo a preparar as pessoas na própria localidade.

Os entrevistados afirmam que, nos últimos dez anos a cidade vem se equipando em termos de ensino e, os programas da Companhia, em conjunto com a Secretaria de Educação favorecem a permanência das pessoas na unidade Itabira. A prática de gestão mais enfatizada tem sido o trabalho diário de comunicação para dentro e para fora. O foco em educação favorece que $43 \%$ do quadro tenham curso superior completo e apenas $10 \%$ não tenham o segundo grau completo.

Os entrevistados consideram que os conflitos sociais e de adaptação em Itabira são menores, quando comparados com outras unidades da Vale. O impacto é quase inexistente para a retenção de talentos. A estrutura remota e, nos dias atuais, relativamente próxima, apresentase como vantagem para que os talentos se retenham nessa unidade. A distância é relativa para as pessoas. A experiência em morar em locais distantes é o que determina a adaptação. $\mathrm{O}$ nível de escolaridade não é o determinante e, de modo geral, a adaptação das pessoas é boa. Esses entrevistados enfatizam que não é factivel a existência de um programa específico para reter talentos. Os talentos se retêm por autodeliberação.

Essa maior proximidade atual com Belo Horizonte tem ajudado as ações de desenvolvimento. Tais ações vêm da corporação e são corroboradas pela unidade, na qual as especificidades são tratadas com autonomia pelos gestores, tanto para tratar conflitos quanto para desenvolver pessoas. E essa proximidade ajuda a retenção espontânea.

O orgulho é fortemente percebido internamente e ficou patenteado em pesquisas de clima organizacional. Os empregados terceirizados e estudantes da região vêem como alvo estimulante para o seu desempenho, a possibilidade de vestir a camisa da Vale em Itabira.

A gerência geral das duas minas tem contribuído para a relação da Companhia com a comunidade, na percepção dos entrevistados. É nítida a mudança de uma cultura de competição para outra de colaboração. A solidariedade é um valor forte dentro dessa nova perspectiva. Como cultura voltada para focar as pessoas, a comunicação direta tem sido incentivada para manter esse foco. O código de ética foi assinado como representação simbólica para o alinhamento entre o discurso e a prática. A intenção é demonstrar que hierarquia é diferente de barreira. 
A questão do desenvolvimento humano, conceitual e técnico está interligada com a resolução de conflitos e é tratada com o diálogo para ampliar os horizontes e o respeito à diversidade cultural que reina entre as pessoas nessa unidade remota. Como resultante, o lucro com o respeito às pessoas e ao meio-ambiente enfatizado na unidade, é declarado inclusive, no ato de desligar alguém, conforme dados dos entrevistados.

A questão como a gestão de pessoas facilita ou dificulta a obtenção do comprometimento organizacional nessa unidade ficou respondida com a opinião, unânime entre os entrevistados, que a filosofia de atuação gerencial é bem difundida para todos os escalões da unidade, que a estrutura de treinamento e desenvolvimento, layout da unidade e o relacionamento com a comunidade mostram o que tem por trás do gerenciamento em Itabira. Ressalte-se que os dados da pesquisa mostram chefias e colegas de todas as áreas e/ou da mesma área estimulando: feedbacks, debates, engajamento, cooperação, valorização do trabalho, reconhecimento pela capacidade de desenvolvimento, confiabilidade e colaboração. Nesse ponto dá-se o cruzamento dos aspectos ligados a comportamento, comprometimento, gestão de pessoas e cultura organizacional, detalhados no quadro $\mathrm{n}^{\circ} .08$ para essa unidade.

\section{1. 3 Unidade: Porto Trombetas - Minério Bauxita}

A empresa, Mineração Rio do Norte, aqui tomada como unidade Porto Trombetas da Companhia Vale do Rio Doce que também detém parte do seu controle acionário, atua de modo autônomo. A autorização para a pesquisa foi gerada pela Vale e corroborada pela unidade.

A missão da Mineração Rio do Norte consiste em "produzir bauxita e fornecer o minério com pleno atendimento às especificações de qualidade, assegurando a satisfação dos clientes e o retorno adequado do investimento de acionistas, mantendo uma relação de profundo respeito ao homem e à natureza."

Ela é uma associação de empresas nacionais e internacionais, instalada no núcleo urbano de Porto Trombetas, município de Oriximiná. Suas operações começaram em 1979 e consistem na extração, beneficiamento, transporte ferroviário, secagm e embarque em navios de minério de bauxita, a matéria prima do alumínio. A exploração da bauxita é feita em mina a céu aberto. A maior parte da sua produção é destinada ao mercado interno. 
É considerada como unidade remota, confinada e isolada. O seu acesso dá-se pelo Rio Trombetas ou pelo Aeroporto próprio. A concepção dessa unidade remota envolveu a criação de toda a infra-estrutura necessária à sua operação.

O quadro $\mathrm{n}^{\mathrm{o}} .10$ mostra o resultado da análise de conteúdo das dezenove entrevistas realizadas nessa unidade.

\begin{tabular}{|c|c|c|c|}
\hline \multicolumn{4}{|c|}{$\begin{array}{c}\text { QUADRO No. } 10 \\
\text { RESULTADO DA ANÁLISE DE CONTEÚDO UNIDADE PORTO TROMBETAS }\end{array}$} \\
\hline \multirow{2}{*}{$\begin{array}{l}\text { Unidade de Codificação } \\
\text { Palavras-tema }\end{array}$} & \multirow[t]{2}{*}{ Palavras-chave ou Frases-chave } & \multicolumn{2}{|c|}{ Contagem } \\
\hline & & Presença & Ausência \\
\hline 1. Feedback & $\begin{array}{l}\text { Estímulo; } \\
\text { Evidência. }\end{array}$ & $\begin{array}{l}16 \\
19\end{array}$ & $\begin{array}{c}03 \\
-\end{array}$ \\
\hline 2. Interações & Integrantes dos diversos escalões. & 17 & 02 \\
\hline 3. Abertura & $\begin{array}{l}\text { Encorajamento para debates; } \\
\text { Ocorrência de debates. }\end{array}$ & $\begin{array}{l}19 \\
19\end{array}$ & $\begin{array}{l}- \\
-\end{array}$ \\
\hline 4. Comunicações interpessoais & Ocorrência entre as áreas. & 15 & 04 \\
\hline 5. Emoções & Expressão. & 17 & 02 \\
\hline 6. Pensar, sentir e agir & Evidência de interface. & 16 & 03 \\
\hline 7. Tomada de decisão & Ocorrência em grupo. & 19 & - \\
\hline 8. Comportamento intergrupal & Favorecendo o trabalho em equipe. & 18 & 01 \\
\hline 9. Participação & Estímulo à atitude de participação do empregado. & 19 & - \\
\hline 10. Envolvimento & $\begin{array}{l}\text { Estímulo à atitude de envolvimento do empregado } \\
\text { com os objetivos organizacionais. }\end{array}$ & 19 & - \\
\hline 11. Comprometimento & $\begin{array}{l}\text { Estímulo à atitude de comprometimento } \\
\text { (identificação) do empregado com os objetivos } \\
\text { organizacionais. }\end{array}$ & 18 & 01 \\
\hline 12. Expectativas & $\begin{array}{l}\text { Possibilidade de o empregado comunicar } \\
\text { expectativas em relação à unidade; } \\
\text { Ocorrência de comunicação das expectativas da } \\
\text { unidade em relação ao empregado. }\end{array}$ & $\begin{array}{l}18 \\
11\end{array}$ & 01 \\
\hline 13. Responsabilidades & $\begin{array}{l}\text { Estímulo para o empregado assumir responsa- } \\
\text { bilidades sobre suas ações. }\end{array}$ & 19 & - \\
\hline 14. Engajamento & $\begin{array}{l}\text { Estímulo ao engajamento das pessoas aos objetivos } \\
\text { e metas organizacionais. }\end{array}$ & 19 & - \\
\hline 15. Características da unidade & $\begin{array}{l}\text { Estimulando as pessoas a despenderem esforços } \\
\text { para nela permanecerem. }\end{array}$ & 17 & 02 \\
\hline 16. Cooperação & $\begin{array}{l}\text { Estímulo à atitude de cooperação; } \\
\text { Evidência da cooperação. }\end{array}$ & $\begin{array}{l}18 \\
19\end{array}$ & $\begin{array}{c}01 \\
-\end{array}$ \\
\hline 17. Valorização & $\begin{array}{l}\text { Evidência da valorização de opiniões e descobertas } \\
\text { em relação à maneira de se obter resultados; } \\
\text { Evidência da valorização do trabalho. }\end{array}$ & 16 & $\begin{array}{l}03 \\
- \\
\end{array}$ \\
\hline 18. Aprendizagem/reaprendizagem & $\begin{array}{l}\text { Reconhecimento da necessidade de apren- } \\
\text { dizagem/reaprendizagem em relação ao trabalho. }\end{array}$ & 16 & 03 \\
\hline 19. Desenvolvimento & $\begin{array}{l}\text { Demonstração do estímulo ao desenvolvimento } \\
\text { pessoal e profissional na própria organização. }\end{array}$ & 18 & 01 \\
\hline 20. Incentivos & $\begin{array}{l}\text { Disponibilização de incentivos vinculados a } \\
\text { resultados obtidos pela equipe. }\end{array}$ & 15 & 04 \\
\hline 21. Reconhecimento & $\begin{array}{l}\text { As pessoas são capazes de: desenvolvimento, } \\
\text { confiança e colaboração. }\end{array}$ & 19 & - \\
\hline $\begin{array}{l}\text { 22. Características organizacionais } \\
\text { da unidade }\end{array}$ & $\begin{array}{l}\text { Atrair e reter pessoas de alto potencial e } \\
\text { qualificação para o trabalho. }\end{array}$ & 12 & 07 \\
\hline $\begin{array}{l}\text { 23. Criação de condições de tra- } \\
\text { balho na unidade }\end{array}$ & $\begin{array}{l}\text { Favoráveis à manutenção da motivação individual } \\
\text { para o trabalho; } \\
\text { Favoráveis à mobilização dos grupos em torno das }\end{array}$ & $\begin{array}{l}16 \\
19\end{array}$ & 03 \\
\hline
\end{tabular}




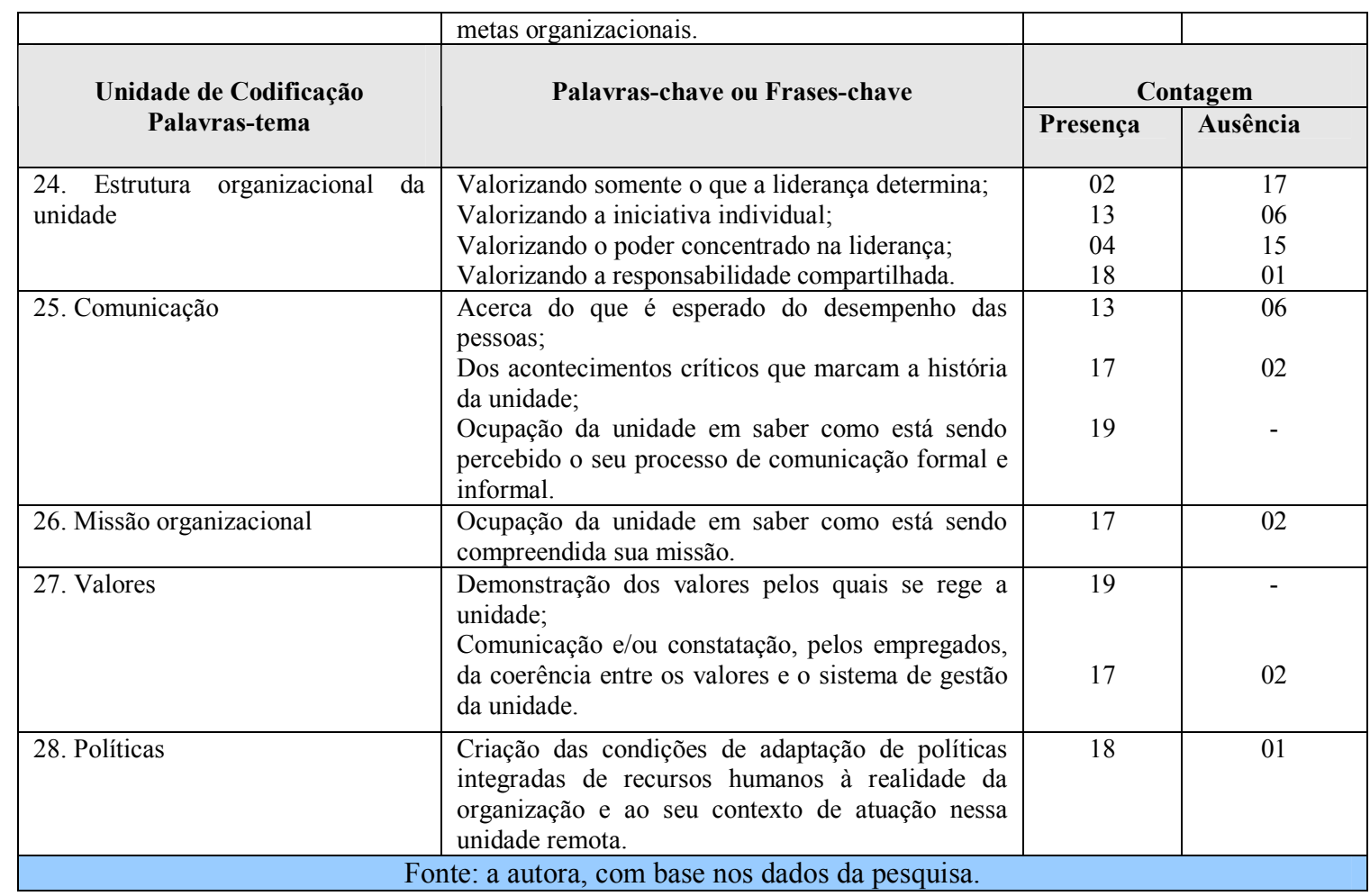

As unidades de codificação 1 a 8 dizem respeito às palavras-tema contidas nos aspectos do comportamento organizacional A contagem de presenças totalitárias nas unidades de codificação 1 (palavras-chave 2), 3 (ambas as frases-chave) e 7, seguida de presenças expressivas nas unidades 2, 5, 8, 9 e 6 mostra uma visão favorável dos entrevistados em relação aos aspectos ligados ao comportamento organizacional. Contudo, as ausências contidas nas palavras-tema 1, 4 (com mais ênfase) e 6, não devem ser consideradas desprezíveis e podem ser conduzidas a um diálogo investigativo das razões.

As unidades de codificação 9 a 16 estão voltadas para as palavras-tema contidas nos aspectos do comprometimento organizacional. A contagem de presenças é quase totalitária em todas elas e denota a favorabilidade, na percepção dos entrevistados, com relação a esses aspectos voltados para o comprometimento. Porém, a unidade de codificação 12, em sua frase-chave 2, mostra que as ausências são bastante significativas e necessitam de investigação das razões que estão nelas embutidas.

As unidades de codificação 17 a 23 referem-se às palavras-tema contidas nos aspectos de gestão estratégica de pessoas. As presenças são totalizadoras nas unidades de codificação 17 (frase-chave 2), 21 e 23 (frase-chave 2); quase totalizadoras na 19; são significativas nas 
unidades de codificação 17 (frase-chave 1), 18 e 23 (frase-chave 1) e todas ela denotam a visão positiva que os entrevistados têm dos aspectos da gestão de pessoas nessa unidade. Entretanto, as ausências observadas na unidade de codificação 22 são significativas e mostram necessidade de investigação para a compreensão das razões.

As unidades de codificação 24 a 28 estão no bojo das palavras-tema contidas nos aspectos da cultura organizacional. Observem-se, nesse quadro, as ausências substanciais na unidade de codificação 24 - estrutura organizacional da unidade - representadas pelas frases-chave "valorizando somente o que a liderança determina" e "valorizando o poder concentrado na liderança". As frases-chave "valorizando a responsabilidade compartilhada" e "valorizando a iniciativa individual" mostram-se com resultados representativos para a confirmação da ausência de rigidez, autoritarismo e centralização nas determinações da liderança, ressaltadas nas outras duas frases-chave.

A unidade de codificação 25 (frase-chave 1) mostra ausências não desprezíveis. As unidades de codificação 25 (frases-chave 2 e 3), 26 e 27 apresentam confirmação da visão favorável dos entrevistados nesses aspectos concernentes à cultura organizacional dessa unidade remota.

O quadro $\mathrm{n}^{\circ}$. 11 apresenta o resultado da análise de conteúdo aplicadado ao escopo da pesquisa nessa unidade remota e contribui para aprofundar a compreensão do que foi mostrado no quadro $\mathrm{n}^{\mathrm{o}} .10$.

\begin{tabular}{|c|c|c|}
\hline \multicolumn{3}{|c|}{$\begin{array}{c}\text { QUADRO No. } 11 \\
\text { RESULTADO DA ANÁLISE DE CONTEÚDO APLICADO AO ESCOPO DA PESQUISA UNIDADE PORTO } \\
\text { TROMBETAS }\end{array}$} \\
\hline Categorias de Análise & $\begin{array}{c}\text { Temas } \\
\text { Significativos }\end{array}$ & Unidade de Codificação \\
\hline $\begin{array}{c}\text { Comportamento } \\
\text { Organizacional }\end{array}$ & $\begin{array}{l}\text { Percepção da con- } \\
\text { tribuição dos indi- } \\
\text { víduos, dos grupos e } \\
\text { da estrutura. }\end{array}$ & $\begin{array}{l}\text { "A estrutura remota facilita, porque aproxima as pessoas inclusive aos } \\
\text { finais de semana. A solidariedade é grande." } \\
\text { "Os grupos de CCQ contribuem muito e são elogiadíssimos." } \\
\text { "A MRN é um grande laboratório: universidade particular com } \\
\text { abertura e facilitação. Patrocina a evolução das pessoas pela } \\
\text { disponibilização de recursos." } \\
\text { "A integração entre o discurso e a prática está bem afinada." } \\
\text { "Contribuição contínua, liberdade para aprender e mudar são tônicas } \\
\text { da estrutura criada e mantida nessa unidade." }\end{array}$ \\
\hline
\end{tabular}




\begin{tabular}{|c|c|c|}
\hline Categorias de Análise & $\begin{array}{c}\text { Temas } \\
\text { Significativos }\end{array}$ & Unidade de Codificação \\
\hline $\begin{array}{c}\text { Comprometimento } \\
\text { Organizacional }\end{array}$ & $\begin{array}{l}\text { Percepção do orgulho } \\
\text { e do empenho } \\
\text { exercido pelos in- } \\
\text { divíduos em favor } \\
\text { dessa unidade re- } \\
\text { mota. }\end{array}$ & $\begin{array}{l}\text { "As pessoas têm orgulho e expressam isso na pesquisa de clima. } \\
\text { Todos são comprometidos e têm empenho com os resultados." } \\
\text { "Com brilho nos olhos, as pessoas demonstram o seu orgulho em } \\
\text { todas as ocasiões." } \\
\text { "Os olhos brilham quando se fala da unidade. Os gerentes começaram } \\
\text { como operadores. Isso gera orgulho. As pessoas de fora podem vir, } \\
\text { mas as de dentro são priorizadas." } \\
\text { "O fato de muita gente ser da região aumenta o orgulho." } \\
\text { "As pessoas demonstram o orgulho pelo que fazem em todas as } \\
\text { circunstâncias." } \\
\text { "O orgulho é muito forte. O empenho ocorre freqüentemente com a } \\
\text { grande maioria das pessoas." } \\
\text { "Orgulho e empenho caminham juntos. Algo a mais é feito sempre, } \\
\text { como se fosse autodesafio." }\end{array}$ \\
\hline $\begin{array}{c}\text { Gestão Estratégica } \\
\text { de Pessoas }\end{array}$ & $\begin{array}{l}\text { Percepção da adoção } \\
\text { de novas práticas de } \\
\text { gestão, de modo a } \\
\text { facilitar as ações de } \\
\text { desenvolvimento e } \\
\text { resolução de conflitos } \\
\text { nessa unidade. }\end{array}$ & $\begin{array}{l}\text { "O envolvimento de todos, do topo ao chão da fábrica, mostram o que } \\
\text { tem por trás da política de gestão participativa de pessoas." } \\
\text { "As principais práticas de gestão são a de segurança e de } \\
\text { relacionamento interpessoal." } \\
\text { "Os planos de ação para melhoria do clima organizacional e ouvidoria } \\
\text { proporcionam resolução para tipos específicos de conflitos." } \\
\text { "Há um quadro maduro. O tempo de empresa das pessoas aqui é alto." }\end{array}$ \\
\hline $\begin{array}{l}\text { Cultura } \\
\text { Organizacional }\end{array}$ & $\begin{array}{l}\text { Percepção do conhe- } \\
\text { cimento que os } \\
\text { indivíduos têm, } \\
\text { acerca da visão, } \\
\text { filosofia de atuação, } \\
\text { missão e valores } \\
\text { nessa unidade remo- } \\
\text { ta. }\end{array}$ & $\begin{array}{l}\text { "Todos entendem os valores, principalmente segurança, } \\
\text { responsabilidade social, cooperação, solidariedade, meio-ambiente e } \\
\text { parceria estão impregnados nas pessoas." } \\
\text { "O amadurecimento e a consciência para políticas, valores e princípios } \\
\text { são muito fortes." } \\
\text { "Não é permitido produzir sem segurança aqui. A segurança está } \\
\text { injetada nas ações das pessoas, principalmente das que estão expostas } \\
\text { aos riscos." } \\
\text { "A cultura é muito forte para a preservação da vida, segurança, saúde } \\
\text { e meio-ambiente. As comunidades ribeirinhas já incorporaram essa } \\
\text { cultura." } \\
\text { "Pode até terminar em demissão, se a pessoa for irresponsável consigo } \\
\text { mesma." }\end{array}$ \\
\hline \multicolumn{3}{|c|}{ autora, com base nos dados da pesquisa. } \\
\hline
\end{tabular}

A estrutura dessa unidade é considerada de excelência para promover a contribuição das pessoas em prol dos resultados organizacionais. O seu foco volta-se para a melhoria contínua do processo de gestão e clima organizacional. Visitas a outras unidades são sistematizadas para o desenvolvimento das pessoas. Há o reconhecimento das melhorias a serem empreendidas e os processos estão em constante mutação. A questão como a gestão de pessoas facilita ou dificulta a obtenção do comprometimento organizacional nessa unidade remota passa a ser respondida nos parágrafos subseqüentes. 
Segundo os dados das entrevistas, a confiança é imprescindível para a operação e há um aprendizado constante de contribuição pelo trabalho em equipe. As pessoas sabem o que fazer, como fazer, e o porquê fazer. Não há necessidade de supervisão acirrada.

Os gerentes começaram na unidade como operadores. O presidente mora na comunidade e convive com todos. Ele veio de uma área de operação. Há ênfase aos programas: café com o presidente e com a direção da empresa que permite troca e funciona como mais uma ação de gestão; programas com jovens aprendizes e de educação de jovens e adultos; gestão por competências; resoluções de conflitos relacionamentos com empregados; conselho de comunicação; crescer em equipe; convênios com instituições de capacitação; reeducação para a resolução de conflito face-a-face; projetos de integração com as famílias e de guia para morar em Trombetas. O programa de visita às áreas envolvendo os familiares é uma especificidade dessa unidade e já foi premiado pela Associação Brasileira de Comunicação Empresarial duas vezes, a primeira no Regional e a segunda no Nacional.

Para os entrevistados, isso tudo gera orgulho, pois, fica claro que as pessoas de fora podem chegar a fazer parte do corpo gerencial, mas as de dentro são priorizadas. O trabalho é prioritariamente desenvolvido em conjunto e o amadurecimento das pessoas com muitos anos na estrutura é relevante para os resultados. $\mathrm{O}$ orgulho de pertencer à unidade é demonstrado de formas variadas: os mais antigos na unidade, o fazem com o tempo empenhado em prol dos melhores resultados; os que chegam, com a garra para fazerem parte da estrutura com empenho elevado e conquistar oportunidades; indicar oportunidades para familiares, amigos ou parentes mais distantes é outra forma de demonstração. A dimensão identidade é a mais pontuada nas pesquisas de clima e satisfação.

De acordo com os entrevistados, as pessoas conhecem bem a visão, os valores, a missão e a filosofia de atuação nessa unidade. Existe um programa de revisão que ajuda a memorizar e, a cada seis meses, tem um programa de validação. Algumas auditorias checam consideram que as pessoas sempre respondem bem aos questionamentos.

Todas as ações reforçam a política. Diariamente, os diálogos de segurança elucidam valores como segurança, meio-ambiente, saúde, relacionamento com a comunidade. Os princípios norteadores da unidade são divulgados com freqüentes reciclagens e, a condição de confinamento propicia a percepção das ações assimiladas pelos moradores. 
O envolvimento de todos os escalões com os objetivos da unidade, bem como a preparação de pessoas para ocuparem cargos mais avançados contribui para a obtenção do comprometimento organizacional nessa unidade. As pessoas que não conseguem adaptar-se ao conjunto de variáveis dessa estrutura remota, isolada e confinada terminam passando pouco tempo. Não há meio-termo. As que chegam demonstram orgulho em contribuir com a sua história. As que saem para outras unidades orgulham-se de terem sido escolhidos pelas competências adquiridas em Trombetas.

Valores como segurança, responsabilidade social, cooperação, solidariedade, parceria, qualidade de vida, abertura para o diálogo, respeito às individualidades, saúde, e meioambiente fazem parte da cultura dentro e fora dessa unidade. A cultura de preservação é fortemente percebida na localidade por meio da participação no programa de consciência ecológica. As comunidades ribeirinhas já incorporaram essa cultura, cuidando da saúde, segurança e meio-ambiente, de acordo com os dados da pesquisa.

A questão de pesquisa que investiga a existência de diferenças entre as culturas das unidades remotas, quais são as diferenças e como elas se evidenciam é respondida nessa unidade com a afirmação dos entrevistados de que, em geral há a percepção de uma cultura própria, adaptada à realidade de Trombetas. A liberdade para desenvolver políticas e filosofia próprias, envolvendo erros e acertos, é parte integrante da história percebida dessa unidade. Existe treinamento para os aposentáveis aprenderem a viver fora da unidade e da comunidade. Não há uma descaracterização da Mineração Rio do Norte por parte dos acionistas. A Vale detém $40 \%$ das ações e não deixa de caracterizar a unidade como ela é. Todos os acionistas trazem contribuições valiosas e reconhecem as contribuições oriundas dessa unidade.

Em função do aquecimento do mercado de minerais, os entrevistados consideram que atrair e reter talentos têm sido os desafios da unidade. Práticas salariais e de benefícios não podem ser equiparadas com localidades próximas aos grandes centros, pois, o risco de não conseguir alcançar esse processo de retenção se torna muito mais alto.

Saliente-se que os dados da pesquisa, nessa unidade, mostram chefias e colegas de todas as áreas e/ou da mesma área estimulando: feedbacks, debates, engajamento, cooperação, valorização do trabalho, reconhecimento pela capacidade de desenvolvimento, confiabilidade e colaboração. Nesse ponto dá-se o cruzamento dos aspectos ligados a comportamento, 
comprometimento, gestão de pessoas e cultura organizacional, detalhados no quadro $\mathrm{n}^{\circ} .10$ para essa unidade.

\section{1. 4 Unidade: Carajás}

Em meados dos anos 60, foi descoberta uma das maiores províncias minerais do mundo, Carajás, no sudeste do Pará. Em 1970 a Vale do Rio Doce associou-se à empresa U.S. Steel criando a AMZA - Amazônia Mineração S.A. para explorar o Projeto Ferro Carajás.

Em 1981 a Companhia adquiriu a exclusividade de explorar minério de ferro, ouro e manganês no local, antes habitado por índios Xikrins do Cateté e remanescentes do Ciclo da Castanha. Deu-se então início à implantação do Projeto Ferro Carajás.

No Vale do rio Parauapebas, começou a ser construída a vila de Parauapebas. A construção dessa vila provocou a migração de muitas pessoas para a área. Em pouco tempo, o povoado do Rio Verde, apesar das condições inferiores em relação aos padrões do núcleo residencial projetado, superou a população prevista.

Essa vila, que havia sido projetada para atender 5.000 habitantes, segundo dados do IBGE, já estava com 20.000 .

Carajás é considerada uma unidade remota, confinada e isolada. Explora ferro e manganês em minas a céu aberto. $\mathrm{O}$ seu acesso dá-se por Aeroporto próprio. A Vale construiu uma rodovia asfaltada entre a cidade de Marabá e as instalações da empresa com cerca de $200 \mathrm{~km}$, posteriormente transferida ao Estado do Pará, que também serve de acesso.

A concepção dessa unidade envolveu a criação de toda a infra-estrutura necessária à sua operação.

Em 1986 deu-se o início de mudança das famílias para o núcleo residencial construído.

O quadro $\mathrm{n}^{\mathrm{o}} .12$ mostra o resultado da análise de conteúdo das dez entrevistas realizadas nessa unidade. 


\begin{tabular}{|c|c|c|c|}
\hline \multicolumn{4}{|c|}{$\begin{array}{l}\text { QUADRO No․ } 12 \\
\text { RESULTADO DA ANÁLISE DE CONTEÚDO UNIDADE CARAJÁS }\end{array}$} \\
\hline \multirow{2}{*}{$\begin{array}{l}\text { Unidade de Codificação } \\
\text { Palavras-tema }\end{array}$} & \multirow[t]{2}{*}{ Palavras-chave ou Frases-chave } & \multicolumn{2}{|c|}{ Contagem } \\
\hline & & Presença & Ausência \\
\hline 1. Feedback & $\begin{array}{l}\text { Estímulo; } \\
\text { Evidência. }\end{array}$ & $\begin{array}{l}08 \\
10\end{array}$ & $\begin{array}{c}02 \\
-\end{array}$ \\
\hline 2. Interações & Integrantes dos diversos escalões. & 06 & 04 \\
\hline 3. Abertura & $\begin{array}{l}\text { Encorajamento para debates; } \\
\text { Ocorrência de debates. }\end{array}$ & $\begin{array}{l}10 \\
10\end{array}$ & - \\
\hline 4. Comunicações interpessoais & Ocorrência entre as áreas. & 06 & 04 \\
\hline 5. Emoções & Expressão. & 06 & 04 \\
\hline 6. Pensar, sentir e agir & Evidência de interface. & 06 & 04 \\
\hline 7. Tomada de decisão & Ocorrência de em grupo. & 08 & 02 \\
\hline 8. Comportamento intergrupal & Favorecendo o trabalho em equipe. & 06 & 04 \\
\hline 9. Participação & Estímulo à atitude de participação do empregado. & 10 & - \\
\hline 10. Envolvimento & $\begin{array}{l}\text { Estímulo à atitude de envolvimento do empregado } \\
\text { com os objetivos organizacionais. }\end{array}$ & 10 & - \\
\hline 11. Comprometimento & $\begin{array}{l}\text { Estímulo à atitude de comprometimento } \\
\text { (identificação) do empregado com os objetivos } \\
\text { organizacionais. }\end{array}$ & 09 & 01 \\
\hline 12. Expectativas & $\begin{array}{l}\text { Possibilidade de o empregado comunicar } \\
\text { expectativas em relação à unidade; } \\
\text { Ocorrência de comunicação das expectativas da } \\
\text { unidade em relação ao empregado. }\end{array}$ & $\begin{array}{l}06 \\
07\end{array}$ & $\begin{array}{l}04 \\
03\end{array}$ \\
\hline 13. Responsabilidades & $\begin{array}{l}\text { Estímulo para o empregado assumir responsa- } \\
\text { bilidades sobre suas ações. }\end{array}$ & 10 & - \\
\hline 14. Engajamento & $\begin{array}{l}\text { Estímulo ao engajamento das pessoas aos objetivos } \\
\text { e metas organizacionais. }\end{array}$ & 10 & - \\
\hline 15. Características da unidade & $\begin{array}{l}\text { Estimulando as pessoas a despenderem esforços } \\
\text { para nela permanecerem. }\end{array}$ & 10 & - \\
\hline 16. Cooperação & $\begin{array}{l}\text { Estímulo à atitude de cooperação; } \\
\text { Evidência da cooperação. }\end{array}$ & $\begin{array}{l}08 \\
10\end{array}$ & $\begin{array}{c}02 \\
-\end{array}$ \\
\hline 17. Valorização & $\begin{array}{l}\text { Evidência da valorização de opiniões e descobertas } \\
\text { em relação à maneira de se obter resultados; } \\
\text { Evidência da valorização do trabalho. }\end{array}$ & $\begin{array}{l}09 \\
10 \\
\end{array}$ & $\begin{array}{l}01 \\
- \\
\end{array}$ \\
\hline 18. Aprendizagem/reaprendizagem & $\begin{array}{l}\begin{array}{l}\text { Reconhecimento da necessidade de apren- } \\
\text { dizagem/reaprendizagem em relação ao trabalho. }\end{array} \\
\end{array}$ & 09 & 01 \\
\hline 19. Desenvolvimento & $\begin{array}{l}\text { Demonstração do estímulo ao desenvolvimento } \\
\text { pessoal e profissional na própria organização. }\end{array}$ & 10 & - \\
\hline 20. Incentivos & $\begin{array}{l}\text { Disponibilização de incentivos vinculados a } \\
\text { resultados obtidos pela equipe. }\end{array}$ & 10 & - \\
\hline 21. Reconhecimento & $\begin{array}{l}\text { As pessoas são capazes de: desenvolvimento, } \\
\text { confiança e colaboração. }\end{array}$ & 10 & - \\
\hline $\begin{array}{l}\text { 22. Características organizacionais } \\
\text { da unidade }\end{array}$ & $\begin{array}{l}\text { Atrair e reter pessoas de alto potencial e } \\
\text { qualificação para o trabalho. }\end{array}$ & 07 & 03 \\
\hline $\begin{array}{l}\text { 23. Criação de condições de trabalho } \\
\text { na unidade }\end{array}$ & $\begin{array}{l}\text { Favoráveis à manutenção da motivação individual } \\
\text { para o trabalho; } \\
\text { Favoráveis à mobilização dos grupos em torno das } \\
\text { metas organizacionais. }\end{array}$ & $\begin{array}{l}07 \\
10\end{array}$ & 03 \\
\hline $\begin{array}{l}\text { 24. Estrutura organizacional da } \\
\text { unidade }\end{array}$ & $\begin{array}{l}\text { Valorizando somente o que a liderança determina; } \\
\text { Valorizando a iniciativa individual; } \\
\text { Valorizando o poder concentrado na liderança; } \\
\text { Valorizando a responsabilidade compartilhada. }\end{array}$ & $\begin{array}{c}01 \\
07 \\
- \\
10\end{array}$ & $\begin{array}{l}09 \\
03 \\
10 \\
-\end{array}$ \\
\hline 25. Comunicação & $\begin{array}{l}\text { Acerca do que é esperado do desempenho das } \\
\text { pessoas; } \\
\text { Dos acontecimentos críticos que marcam a história } \\
\text { da unidade; } \\
\text { Ocupação da unidade em saber como está sendo } \\
\text { percebido o seu processo de comunicação formal e } \\
\text { informal. }\end{array}$ & $\begin{array}{l}09 \\
10 \\
08\end{array}$ & $\begin{array}{c}01 \\
- \\
02\end{array}$ \\
\hline
\end{tabular}




\begin{tabular}{|l|l|c|c|}
\hline \multicolumn{1}{|c|}{$\begin{array}{c}\text { Unidade de Codificação } \\
\text { Palavras-tema }\end{array}$} & \multicolumn{1}{|c|}{ Palavras-chave ou Frases-chave } & \multicolumn{2}{c|}{ Contagem } \\
\cline { 2 - 4 } & \multicolumn{1}{|c|}{ Presença } & Ausência \\
\hline 26. Missão organizacional & $\begin{array}{l}\text { Ocupação da unidade em saber como está sendo } \\
\text { compreendida sua missão. }\end{array}$ & 09 & 01 \\
\hline 27. Valores & $\begin{array}{l}\text { Demonstração dos valores pelos quais se rege a } \\
\text { unidade; } \\
\text { Comunicação e/ou constatação, pelos empregados, } \\
\text { da coerência entre os valores e o sistema de gestão } \\
\text { da unidade. }\end{array}$ & 09 & 03 \\
\hline 28. Políticas & $\begin{array}{l}\text { Criação das condições de adaptação de políticas } \\
\text { integradas de recursos humanos à realidade da } \\
\text { organização e ao seu contexto de atuação nessa } \\
\text { unidade remota. }\end{array}$ & 07 & 03 \\
\hline
\end{tabular}

As unidades de codificação 1 a 8 dizem respeito às palavras-tema contidas nos aspectos do comportamento organizacional. A contagem de presenças totalitárias nas unidades de codificação 1 (palavra-chave 2) e 3 (ambas as frases-chave), seguida de presenças expressivas nas unidades de codificação 1 (palavra-chave 1) e 7 mostra uma visão favorável dos entrevistados em relação aos aspectos ligados ao comportamento organizacional. No entanto, as ausências contidas nas palavras-tema 2, 4, 5, 6 e 8 são significativas e podem ser conduzidas a um diálogo investigativo das razões.

As unidades de codificação 9 a 16 estão voltadas para as palavras-tema contidas nos aspectos do comprometimento organizacional. A contagem de presenças é totalitária nas unidades de codificação 9, 10, 13, 14, 15 e 16 (frase-chave 2) e expressiva nas 11 e 16 (frase-chave 1), o que denota a favorabilidade, na percepção dos entrevistados, com relação a esses aspectos voltados para o comprometimento. A unidade de codificação 12, em ambas as frases-chave, mostra que as ausências são significativas e necessitam de investigação das razões que estão nelas embutidas.

As unidades de codificação 17 a 23 referem-se às palavras-tema contidas nos aspectos de gestão estratégica de pessoas. As presenças são totalizadoras nas unidades de codificação 17 (frase-chave 2), 19, 20, 21 e 23 (frase-chave 2); quase totalizadoras nas 17 (frase-chave 1) e 18 e todas elas denotam a visão positiva que os entrevistados têm dos aspectos da gestão de pessoas. As ausências observadas nas unidades de codificação 22 e 23 (frase-chave 1) já mostram necessidade de investigação para a compreensão das razões. 
As unidades de codificação 24 a 28 estão no bojo das palavras-tema contidas nos aspectos da cultura organizacional. Notem-se, nesse quadro, as ausências totais e substanciais na unidade de codificação 24 - estrutura organizacional da unidade, representadas pelas fraseschave "valorizando o poder concentrado na liderança" e "valorizando somente o que a liderança determina".

As frases-chave "valorizando a responsabilidade compartilhada" e "valorizando a iniciativa individual" mostram-se confirmatórias da ausência de rigidez, autoritarismo e centralização nas determinações da liderança, podendo denotar uma estrutura de poder descentralizada, principalmente pelo que diz respeito ao compartilhamento expresso.

As unidades de codificação 25 (frases-chave 1, 2 e 3), 26 e 27, apresentam confirmação da visão favorável dos entrevistados, nesses aspectos concernentes à cultura organizacional dessa unidade remota. A 28 , já chama a atenção para a necessidade de investigação do significado das ausências.

O quadro $n^{\circ}$. 13 apresenta o resultado da análise de conteúdo aplicadado ao escopo da pesquisa nessa unidade remota e contribui para aprofundar a compreensão do que foi mostrado no quadro $\mathrm{n}^{\mathrm{o}} .12$.

QUADRO No. 13

RESULTADO DA ANÁLISE DE CONTEÚDO APLICADO AO ESCOPO DA PESQUISA UNIDADE CARAJÁS

\begin{tabular}{|c|c|c|}
\hline Categorias de Análise & $\begin{array}{c}\text { Temas } \\
\text { Significativos }\end{array}$ & Unidade de Codificação \\
\hline $\begin{array}{c}\text { Comportamento } \\
\text { Organizacional }\end{array}$ & $\begin{array}{l}\text { Percepção da con- } \\
\text { tribuição dos indi- } \\
\text { víduos, dos grupos e } \\
\text { da estrutura. }\end{array}$ & $\begin{array}{l}\text { "Os indivíduos mudam com a organização e com a estrutura que vem } \\
\text { diminuindo o isolamento." } \\
\text { "Existe uma zona de estímulos entre indivíduos e grupos e entre } \\
\text { grupos e organização. A tecnologia, em suas diversas dimensões, vem } \\
\text { contribuindo cada vez mais com a diminuição do isolamento." } \\
\text { "Há um alinhamento das pessoas no agir, forma de pensar, desafios, } \\
\text { com as mudanças constantes." } \\
\text { "Os indivíduos se sentem donos do negócio e usam a criatividade. } \\
\text { Não têm medo de errar e as contribuições são recebidas." } \\
\text { "Temos uma significativa requisição de atividades em grupo e uma } \\
\text { necessidade de interações entre empregados e equipes." } \\
\text { "Os indivíduos se esforçam para fazer jus às oportunidades de } \\
\text { crescimento profissional, treinamento, conhecimento de novas } \\
\text { realidades, com morar em várias regiões do país e até em outros } \\
\text { países." }\end{array}$ \\
\hline
\end{tabular}




\begin{tabular}{|c|c|c|}
\hline Categorias de Análise & $\begin{array}{c}\text { Temas } \\
\text { Significativos }\end{array}$ & Unidade de Codificação \\
\hline $\begin{array}{c}\text { Comprometimento } \\
\text { Organizacional }\end{array}$ & $\begin{array}{l}\text { Percepção do orgu- } \\
\text { lho e do empenho } \\
\text { exercidos pelos in- } \\
\text { divíduos em favor } \\
\text { dessa unidade. }\end{array}$ & $\begin{array}{l}\text { "A história de muitos empregados é a história de Carajás. O tamanho } \\
\text { do orgulho é proporcional à grandiosidade do sucesso. O empenho } \\
\text { caminha junto e as características do ambiente favorecem." } \\
\text { "As pessoas demonstram muito orgulho e estão alinhadas com os } \\
\text { objetivos da empresa." } \\
\text { "O empenho delas é indiscutível e há vibração pelos resultados } \\
\text { obtidos. Tudo isso é muito forte e são inúmeros os exemplos que } \\
\text { podem reforçar." } \\
\text { "O orgulho está estampado na fisionomia das pessoas. As que são da } \\
\text { região, por trabalharem em uma empresa desse porte. As que vieram } \\
\text { de fora, por terem se adaptado e criado as suas próprias estruturas para } \\
\text { aqui ficarem. Os que já estão há muito tempo, o orgulho de ter } \\
\text { incrustado o seu nome na história de uma unidade considerada a maior } \\
\text { mina de ferro a céu aberto do mundo." } \\
\text { "O orgulho é percebido por meio do comprometimento para o } \\
\text { cumprimento das metas e o envolvimento da equipe na superação de } \\
\text { todos os obstáculos é uma marca na unidade." } \\
\text { "Orgulho e empenho são causa e conseqüência." } \\
\text { "O orgulho em mostrar as melhorias da unidade é emocionante. O } \\
\text { clima fica leve." } \\
\text { "As pessoas demonstram muito orgulho em trabalhar na unidade." } \\
\text { "As pessoas estão muito alinhadas aos objetivos da empresa e querem } \\
\text { vê-la como a primeira do mundo." }\end{array}$ \\
\hline $\begin{array}{c}\text { Gestão Estratégica } \\
\text { de Pessoas }\end{array}$ & $\begin{array}{l}\text { Percepção da adoção } \\
\text { de novas práticas de } \\
\text { gestão, de modo a } \\
\text { facilitar as ações de } \\
\text { desenvolvimento e } \\
\text { resolução de conflitos } \\
\text { nessa unidade. }\end{array}$ & $\begin{array}{l}\text { "A adoção da estratégia de desenvolvimento usando as pessoas da } \\
\text { região, considerada como desenvolvimento responsável, tem como } \\
\text { meta buscar ao máximo as pessoas locais." } \\
\text { "Há metas claras de desenvolver os fornecedores de Parauapebas, } \\
\text { Marabá e Belém e manter o diálogo entre as comunidades." } \\
\text { "A criação de centro de tecnologia mineral para criar o pólo de } \\
\text { formação alinhado ao negócio é uma realidade." } \\
\text { "Preparar as pessoas para ocuparem cargos mais altos é tão gostoso } \\
\text { quanto produzir. Todos crescem juntos." } \\
\text { "Mesclar velhos e novos supervisores é ponto forte para o } \\
\text { mapeamento dos destaques nas contribuições. Os resultados } \\
\text { comprovam." } \\
\text { "Temos um moderno sistema de remuneração variável." } \\
\text { "No ano passado } 100 \% \text { dos gestores foram preparados e treinados } \\
\text { para lidar com o desenvolvimento de pessoas." }\end{array}$ \\
\hline $\begin{array}{c}\text { Cultura } \\
\text { Organizacional }\end{array}$ & $\begin{array}{l}\text { Percepção do co- } \\
\text { nhecimento que os } \\
\text { indivíduos têm, } \\
\text { acerca da visão, } \\
\text { filosofia de atuação, } \\
\text { missão e valores } \\
\text { nessa unidade remo- } \\
\text { ta. }\end{array}$ & $\begin{array}{l}\text { "Ao longo do tempo visão missão filosofia de atuação são } \\
\text { incorporados ao cotidiano das ações." } \\
\text { "Valores como segurança, meio-ambiente, comunicação com a } \\
\text { comunidade e sustentabilidade são mais facilmente incorporados." } \\
\text { "A solidariedade é um valor forte. Os gestores têm oportunidade de } \\
\text { transmitir isso e o clima só melhora. É importante sentir segurança nas } \\
\text { relações também. Os seres humanos são responsáveis pelos números." } \\
\text { "Os valores mais evidenciados no cotidiano da unidade são segurança, } \\
\text { meio-ambiente, e comunicação com a comunidade." }\end{array}$ \\
\hline & & m base nos dados da pesquisa. \\
\hline
\end{tabular}


Os entrevistados salientam que, por ser uma unidade com núcleos de moradia isolados, a contribuição é percebida dentro e fora do ambiente de trabalho. Nos dias atuais, as pessoas que vêm de fora ainda são agraciadas com a moradia no núcleo residencial interno. As contratadas na região moram em Parauapebas e representam 70\%. Em ambas as circunstâncias, essa estrutura remota é tida como solidária e aproximadora, o que contribui para os seus resultados globais. A questão como a gestão de pessoas facilita ou difículta a obtenção do comprometimento organizacional nessa unidade remota passa a ser respondida nos parágrafos subseqüentes.

Os dados das entrevistas apontam a percepção de um ambiente competitivo e de intensa busca por resultados rápidos, o que, em algumas circunstâncias gera mais conflito que sinergia. A corporação tem consciência dessa realidade e atua no sentido de incentivar a cooperação entre as diferentes áreas da unidade. Tal atuação inicia-se a partir da adoção do Centro de Serviços Compartilhados - CSC, na qual se tem, no âmbito da Vale, um modelo de relacionamento entre as Unidades de Negócio, o Centro Corporativo e o CSC, ou seja, um modelo matricial que busca maximizar a sinergia e minimizar os conflitos entre os processos operacionais e corporativos. Se em determinadas cirscunstâncias são identificados conflitos, em outras é evidenciado o processo de motivação e comprometimento dos empregados com as metas de crescimento da unidade.

A Vale é considerada pelos entrevistados como uma empresa de cultura forte e possui moderno sistema de remuneração variável que privilegia o mérito, a performance e o potencial das pessoas. Eles reforçam que essas pessoas contribuem nessa unidade remota porque elas são muito motivadas. A estrutura facilita porque gera oportunidades de crescimento e desenvolvimento pessoal e profissional. Os resultados aparecem em razão da junção das contribuições das pessoas e da estrutura.

O grande diferencial de Carajás é a capacidade de mobilização das pessoas. Os entrevistados afirmaram que em vinte anos nunca souberam de um acordo coletivo que corresse o risco de não ser aprovado. No contexto do moderno sistema de remuneração variável, os indicadores de desempenho são individuais e grupais. Há significativa requisição de atividades em equipes e intensificada necessidade de interações entre elas. 
O sistema de avaliação da empresa incentiva e premia a forma de paricipação e atuação do indivíduo no trabalho em equipe. A ação de incentivar a participação, desde o momento do ingresso nessa unidade, tem propiciado um ambiente favorável à integração, ao treinamento, à capacitação e à integração funcional, o que, em conseqüência, tende a contribuir para um olhar diferenciado com relação às praticas e aos processos da empresa.

O ganho para a unidade Carajás tem sido sido a diminuição da rotatividade, de acordo com os entrevistados. Eles consideram que a adaptação é mais fácil entre as pessoas de escalões mais baixos, pois elas se orgulham em poder propiciar uma vida melhor para as famílias, ao passo que as mais intelectualizadas tendem a valorizar outras coisas encontradas nos grandes centros e por isso passam pouco tempo na região.

As ações dos gestores são consideradas como facilitadoras. Os desafios são sempre colocados como impulsionadores nessa unidade. A possibilidade de evolução das pessoas, desde a fase de aprendizes até a ocupação de níveis gerenciais, é considerada atrativa e, os que conseguem adaptar-se mostram o orgulho pela trajetória. Os conflitos, quando aparecem, são solucionados por meio de diálogos facilitados por esses gestores.

A gestão participativa facilita o desenvolvimento das pessoas e da região, além de minimizar conflitos com a comunidade. O estímulo para estudar, outra ação considerada relevante na atuação dos gestores, redundou em elevação da escolaridade das pessoas da região e já atinge $50 \%$ de universitários, $90 \%$ de técnicos e $100 \%$ de nível médio.

A estratégia de aproximação com a comunidade favorece o desenvolvimento e reduz os conflitos gerados no isolamento do núcleo habitacional interno. As práticas desse projeto social envolvem Parauapebas e o Pitágoras. Se no passado houve uma relação tumultuada com a comunidade, a unidade hoje vive uma realidade de tranqüilidade.

A questão de pesquisa que investiga a existência de diferenças entre as culturas das unidades remotas, quais são as diferenças e como elas se evidenciam é respondida, nessa unidade, com a valorização da educação para o trabalho, a capacitação profissional e o desenvolvimento humano, considerados contribuições efetivas da estrutura. Ainda que o investimento seja de longo prazo, há a política de preparar a mão-de-obra regional, alocando as pessoas de outras regiões do país apenas em casos de necessidade imediata. 
Essas ações de desenvolvimento envolvem parcerias com o governo do Estado e com outras empresas privadas. A percepção dos entrevistados é a de que, ainda que os valores (ética e transparência, excelência de desempenho, espírito desenvolvimentista, responsabilidade econômica, social e ambiental, respeito à vida, respeito à diversidade, e orgulho de ser Vale), a missão e a visão não sejam conhecidos como descritos, a essência de todos eles está internalizada e incorporada nas atividades cotidianas.

Atente-se que os dados da pesquisa, nessa unidade, mostram chefias e colegas de todas as áreas e/ou da mesma área estimulando: feedbacks, debates, engajamento, valorização do trabalho, reconhecimento pela capacidade de desenvolvimento, confiabilidade e colaboração. Nesse ponto dá-se o cruzamento dos aspectos ligados a comportamento, comprometimento, gestão de pessoas e cultura organizacional, detalhados no quadro $\mathrm{n}^{\circ} .12$ para essa unidade.

\section{1. 5 Unidade: Canã̃ dos Carajás - Mina Sossego}

Canaã dos Carajás é um município brasileiro do Estado do Pará. A sua povoação teve origem em um assentamento agrícola dos anos 80 e, em 1997, o município foi criado a partir da criação de Parauapebas. Esse município tem uma formação basicamente agrícola e sua economia gira em torno da cultura do arroz, milho e feijão.

O início da exploração comercial de minério de cobre, em suas formas oxidada e sulfetada pela Companhia Vale do Rio Doce deu-se em meados de 2003. A cidade de Canaã vem crescendo graças à Companhia, a qual motivou o desenvolvimento do município que hoje apresenta um forte crescimento demográfico e econômico. O município possui minas de diamantes, bauxita, níquel vermelho, cobre e ouro.

Canaã dos Carajás é considerada como unidade remota, confinada, semi-isolada e o seu acesso dá-se por estrada construída pela Companhia, ligando-a à unideda de Carajás. A mina Sossego explora cobre a céu aberto.

O quadro $\mathrm{n}^{\circ} .14$ mostra o resultado da análise de conteúdo das dez entrevistas realizadas nessa unidade. 


\begin{tabular}{|c|c|c|c|}
\hline \multicolumn{4}{|c|}{$\begin{array}{l}\text { QUADRO Nº } 14 \\
\text { RESULTADO DA ANÁLISE DE CONTEÚDO UNIDADE CANAÃ DOS CARAJÁS }\end{array}$} \\
\hline \multirow{2}{*}{$\begin{array}{l}\text { Unidade de Codificação } \\
\text { Palavras-tema }\end{array}$} & \multirow[t]{2}{*}{ Palavras-chave ou Frases-chave } & \multicolumn{2}{|c|}{ Contagem } \\
\hline & & Presença & Ausência \\
\hline 1. Feedback & $\begin{array}{l}\text { Estímulo; } \\
\text { Evidência. }\end{array}$ & $\begin{array}{l}10 \\
10\end{array}$ & $\begin{array}{l}- \\
-\end{array}$ \\
\hline 2. Interações & Integrantes dos diversos escalões. & 08 & 02 \\
\hline 3. Abertura & $\begin{array}{l}\text { Encorajamento para debates; } \\
\text { Ocorrência de debates. }\end{array}$ & $\begin{array}{l}09 \\
10\end{array}$ & $\begin{array}{c}01 \\
-\end{array}$ \\
\hline 4. Comunicações interpessoais & Ocorrência entre as áreas. & 06 & 04 \\
\hline 5. Emoções & Expressão. & 08 & 02 \\
\hline 6. Pensar, sentir e agir & Evidência de interface. & 04 & 06 \\
\hline 7. Tomada de decisão & Ocorrência de em grupo. & 08 & 02 \\
\hline 8. Comportamento intergrupal & Favorecendo o trabalho em equipe. & 10 & - \\
\hline 9. Participação & Estímulo à atitude de participação do empregado. & 09 & 01 \\
\hline 10. Envolvimento & $\begin{array}{l}\text { Estímulo à atitude de envolvimento do empregado } \\
\text { com os objetivos organizacionais. }\end{array}$ & 09 & 01 \\
\hline 11. Comprometimento & $\begin{array}{l}\text { Estímulo à atitude de comprometimento } \\
\text { (identificação) do empregado com os objetivos } \\
\text { organizacionais. }\end{array}$ & 09 & 01 \\
\hline 12. Expectativas & $\begin{array}{l}\text { Possibilidade de o empregado comunicar } \\
\text { expectativas em relação à unidade; } \\
\text { Ocorrência de comunicação das expectativas da } \\
\text { unidade em relação ao empregado. }\end{array}$ & $\begin{array}{l}07 \\
09\end{array}$ & $\begin{array}{l}03 \\
01\end{array}$ \\
\hline 13. Responsabilidades & $\begin{array}{l}\text { Estímulo para o empregado assumir responsa- } \\
\text { bilidades sobre suas ações. }\end{array}$ & 10 & - \\
\hline 14. Engajamento & $\begin{array}{l}\text { Estímulo ao engajamento das pessoas aos objetivos } \\
\text { e metas organizacionais. }\end{array}$ & 10 & - \\
\hline 15. Características da unidade & $\begin{array}{l}\text { Estimulando as pessoas a despenderem esforços } \\
\text { para nela permanecerem. }\end{array}$ & 09 & 01 \\
\hline 16. Cooperação & $\begin{array}{l}\text { Estímulo à atitude de cooperação; } \\
\text { Evidência da cooperação. }\end{array}$ & $\begin{array}{l}07 \\
10\end{array}$ & $\begin{array}{c}03 \\
-\end{array}$ \\
\hline 17. Valorização & $\begin{array}{l}\text { Evidência da valorização de opiniões e descobertas } \\
\text { em relação à maneira de se obter resultados; } \\
\text { Evidência da valorização do trabalho. }\end{array}$ & $\begin{array}{l}08 \\
10 \\
\end{array}$ & $\begin{array}{l}02 \\
- \\
\end{array}$ \\
\hline 18. Aprendizagem/reaprendizagem & $\begin{array}{l}\text { Reconhecimento da necessidade de apren- } \\
\text { dizagem/reaprendizagem em relação ao trabalho. }\end{array}$ & 08 & 02 \\
\hline 19. Desenvolvimento & $\begin{array}{l}\text { Demonstração do estímulo ao desenvolvimento } \\
\text { pessoal e profissional na própria organização. }\end{array}$ & 08 & 02 \\
\hline 20. Incentivos & $\begin{array}{l}\text { Disponibilização de incentivos vinculados a } \\
\text { resultados obtidos pela equipe. }\end{array}$ & 08 & 02 \\
\hline 21. Reconhecimento & $\begin{array}{l}\text { As pessoas são capazes de: desenvolvimento, } \\
\text { confiança e colaboração. }\end{array}$ & 10 & - \\
\hline $\begin{array}{l}\text { 22. Características organizacionais } \\
\text { da unidade }\end{array}$ & $\begin{array}{l}\text { Atrair e reter pessoas de alto potencial e } \\
\text { qualificação para o trabalho. }\end{array}$ & 04 & 06 \\
\hline $\begin{array}{l}\text { 23. Criação de condições de trabalho } \\
\text { na unidade }\end{array}$ & $\begin{array}{l}\text { Favoráveis à manutenção da motivação individual } \\
\text { para o trabalho; } \\
\text { Favoráveis à mobilização dos grupos em torno das } \\
\text { metas organizacionais. }\end{array}$ & $\begin{array}{l}08 \\
09\end{array}$ & $\begin{array}{l}02 \\
01\end{array}$ \\
\hline $\begin{array}{l}\text { 24. Estrutura organizacional da } \\
\text { unidade }\end{array}$ & $\begin{array}{l}\text { Valorizando somente o que a liderança determina; } \\
\text { Valorizando a iniciativa individual; } \\
\text { Valorizando o poder concentrado na liderança; } \\
\text { Valorizando a responsabilidade compartilhada. }\end{array}$ & $\begin{array}{c}- \\
06 \\
- \\
08\end{array}$ & $\begin{array}{l}10 \\
04 \\
10 \\
02\end{array}$ \\
\hline 25. Comunicação & $\begin{array}{l}\text { Acerca do que é esperado do desempenho das } \\
\text { pessoas; } \\
\text { Dos acontecimentos críticos que marcam a história } \\
\text { da unidade; } \\
\text { Ocupação da unidade em saber como está sendo } \\
\text { percebido o seu processo de comunicação formal e } \\
\text { informal. }\end{array}$ & $\begin{array}{l}09 \\
08 \\
09\end{array}$ & $\begin{array}{l}01 \\
02 \\
01\end{array}$ \\
\hline
\end{tabular}




\begin{tabular}{|l|l|c|c|}
\hline \multicolumn{1}{|c|}{$\begin{array}{c}\text { Unidade de Codificação } \\
\text { Palavras-tema }\end{array}$} & \multicolumn{1}{|c|}{ Palavras-chave ou Frases-chave } & Contagem \\
\cline { 2 - 4 } & $\begin{array}{l}\text { Presença } \\
\text { 26. Missão organizacional }\end{array}$ & $\begin{array}{l}\text { Ocupação da unidade em saber como está sendo } \\
\text { compreendida sua missão. }\end{array}$ & 09 \\
\hline 27. Valores & $\begin{array}{l}\text { Demonstração dos valores pelos quais se rege a } \\
\text { unidade; } \\
\text { Comunicação e/ou constatação, pelos empregados, } \\
\text { da coerência entre os valores e o sistema de gestão } \\
\text { da unidade. }\end{array}$ & 09 & 01 \\
\hline 28. Políticas & $\begin{array}{l}\text { Criação das condições de adaptação de políticas } \\
\text { integradas de recursos humanos à realidade da } \\
\text { organização e ao seu contexto de atuação nessa } \\
\text { unidade. }\end{array}$ & 08 & 02 \\
\hline
\end{tabular}

As unidades de codificação 1 a 8 dizem respeito às palavras-tema contidas nos aspectos do comportamento organizacional. A contagem de presenças totalitárias nas unidades de codificação 1 (palavras-chave 1 e 2), 3 (frase-chave 2) e 8, seguida de presenças expressivas nas unidades 3 (palavras-chave 1), 2, 5 e 7, mostra uma visão favorável dos entrevistados em relação aos aspectos ligados ao comportamento organizacional. Entretanto, as ausências contidas nas palavras-tema 4 e 6 são expressivas e podem ser conduzidas a um diálogo investigativo das razões pelas quais elas assim aparecem.

As unidades de codificação 9 a 16 estão voltadas para as palavras-tema contidas nos aspectos do comprometimento organizacional. A contagem de presenças é totalitária nas unidades de codificação 13, 14, e 16 (frase-chave 2) e expressiva nas unidades de codificação 9, 10, 11, 12 (frase-chave 2) e 15, o que denota a favorabilidade, na percepção dos entrevistados, com relação a esses aspectos voltados para o comprometimento. As unidades de codificação 12 (frase-chave 1) e 16 (frase-chave 1) alertam que as ausências são significativas e necessitam de investigação das razões que estão nelas embutidas.

As unidades de codificação 17 a 23 referem-se às palavras-tema contidas nos aspectos de gestão de pessoas. As presenças são totalizadoras nas unidades de codificação 17 (frase-chave 2) e 21; quase totalizadoras nas 17 (frase-chave 1), 18, 19, 20 e 23 (frase-chave 1) e todas elas denotam a visão positiva que os entrevistados têm dos aspectos da gestão de pessoas nessa unidade. As ausências observadas nas unidades de codificação 22 são expressivas e mostram necessidade de investigação para a compreensão das razões. 
As unidades de codificação 24 a 28 estão no bojo das palavras-tema contidas nos aspectos da cultura organizacional. Enfatizem-se, nesse quadro, as ausências totais na unidade de codificação 24 - estrutura organizacional da unidade, representadas pelas frases-chave "valorizando somente o que a liderança determina" e "valorizando o poder concentrado na liderança". As frases-chave "valorizando a responsabilidade compartilhada" e "valorizando a iniciativa individual" mostram-se confirmatórias da ausência de rigidez, autoritarismo e centralização nas determinações da liderança, e de uma estrutura de poder centralizada, principalmente pelo que diz respeito ao compartilhamento expresso.

As unidades de codificação 25, 26, 27 e 28 apresentam confirmação da visão favorável dos entrevistados nesses aspectos concernentes à cultura organizacional dessa unidade remota. $\mathrm{O}$ quadro $\mathrm{n}^{\circ} .15$ apresenta o resultado da análise de conteúdo aplicadado ao escopo da pesquisa e contribui para aprofundar a compreensão do que foi mostrado no quadro $n^{\circ} .14$.

\begin{tabular}{|c|c|c|}
\hline \multicolumn{3}{|c|}{$\begin{array}{l}\text { QUADRO No } 15 \\
\text { RESULTADO DA ANÁLISE DE CONTEÚDO APLICADO AO ESCOPO DA PESQUISA } \\
\text { UNIDADE CANAÃ DOS CARAJÁS }\end{array}$} \\
\hline $\begin{array}{l}\text { Categorias de } \\
\text { Análise }\end{array}$ & Temas Significativos & Unidade de Codificação \\
\hline $\begin{array}{c}\text { Comportamento } \\
\text { Organizacional }\end{array}$ & $\begin{array}{l}\text { Percepção da contribuição dos } \\
\text { indivíduos, dos grupos e da } \\
\text { estrutura. }\end{array}$ & $\begin{array}{l}\text { "A estratégia de preparar mão-de-obra, serviços e formadores } \\
\text { de bens da própria região é também uma ação facilitadora para } \\
\text { que as contribuições sejam mais prodigiosas." } \\
\text { "A estrutura contribui facilitando para que as pessoas possam } \\
\text { querer permanecer na unidade." } \\
\text { "A estrutura favorece a responsabilidade compartilhada e é } \\
\text { essa a sua contribuição." } \\
\text { "As contribuições dos indivíduos vêm, em decorrência de suas } \\
\text { próprias motivações para contribuir." } \\
\text { "Já é percebido o trabalho com transparência e feedback } \\
\text { constante." } \\
\text { "Transformar recursos minerais em riquezas e desen- } \\
\text { volvimento sustentável é a contribuição dos indivíduos, do } \\
\text { grupo e da estrutura para o desenvolvimento da região e do } \\
\text { país." }\end{array}$ \\
\hline $\begin{array}{c}\text { Comprometimento } \\
\text { Organizacional }\end{array}$ & $\begin{array}{lll}\text { Percepção do orgulho } & \text { e do } \\
\text { empenho } & \text { exercido } & \text { pelos } \\
\text { indivíduos } & \text { em favor } & \text { dessa } \\
\text { unidade. } & & \end{array}$ & $\begin{array}{l}\text { "É uma unidade nova, orgulho e empenho são mostrados pelas } \\
\text { pessoas da região, por sentirem que estão sendo valorizadas." } \\
\text { "As pessoas que vieram de outras unidades têm o desafio de se } \\
\text { fixar fora da sua origem, também se orgulham quando } \\
\text { conseguem." } \\
\text { "Aqui, a companhia abriu as portas para o trabalho com as } \\
\text { pessoas da região. Esse desafio é devolvido com o empenho e } \\
\text { o orgulho demonstrados pela dedicação ao trabalho." }\end{array}$ \\
\hline
\end{tabular}




\begin{tabular}{|c|c|c|}
\hline & & $\begin{array}{l}\text { "A equipe técnica resolve muitas questões para a unidade e } \\
\text { para a Companhia." } \\
\text { "As ações observadas nos resultados dos grupos de trabalho } \\
\text { são carregadas de comprometimento." }\end{array}$ \\
\hline $\begin{array}{l}\text { Categorias de } \\
\text { Análise }\end{array}$ & Temas Significativos & Unidade de Codificação \\
\hline $\begin{array}{c}\text { Gestão Estratégica } \\
\text { de Pessoas }\end{array}$ & $\begin{array}{l}\text { Percepção da adoção de novas } \\
\text { práticas de gestão, de modo a } \\
\text { facilitar as ações de } \\
\text { desenvolvimento e resolução } \\
\text { de conflitos nessa unidade. }\end{array}$ & $\begin{array}{l}\text { "A forma de gestão da unidade é simples, porque só se ocupa } \\
\text { em fazer com que as pessoas dêem o têm de melhor e, em } \\
\text { geral, elas querem isso." } \\
\text { "A promoção de pessoas da terra, desde aprendiz aos cargos } \\
\text { mais altos serve de estímulos e são possibilidades visíveis." } \\
\text { "As ações dos gestores são adotadas a cada necessidade de } \\
\text { gerenciamento entre as áreas. Eles são os principais } \\
\text { responsáveis no trato dos conflitos." } \\
\text { "A proximidade com a operação da mina facilita a gestão." } \\
\text { "Servir gerencialmente significa dar recursos, orientar/nortear } \\
\text { e obter resultados como conseqüência." } \\
\text { "Gerenciar as pessoas aqui é, sobretudo, entender que a parte } \\
\text { técnica é fácil de aprender e o cuidado maior reside nas } \\
\text { competências interpessoais." }\end{array}$ \\
\hline $\begin{array}{c}\text { Cultura } \\
\text { Organizacional }\end{array}$ & $\begin{array}{l}\text { Percepção do conhecimento } \\
\text { que os indivíduos têm, acerca } \\
\text { da visão, filosofia de atuação, } \\
\text { missão e valores nessa unidade } \\
\text { remota. }\end{array}$ & $\begin{array}{l}\text { "O trabalho de conscientização é feito desde a entrada das } \\
\text { pessoas e, como elas dão respostas rápidas, a incorporação dos } \\
\text { valores é também rápida." } \\
\text { "Os valores não são tão diferentes da realidade da maioria dos } \\
\text { funcionários. Por ignorância, no passado as pessoas da região } \\
\text { não davam importância ao meio-ambiente a não existia a idéia } \\
\text { de sustentabilidade." } \\
\text { "A integração entre a empresa e a comunidade é um ponto que } \\
\text { vem sendo tratado com cuidado." } \\
\text { "O processo de lembrar a visão, a missão, os valores e a } \\
\text { filosofia de atuação da unidade é diário, nas reuniões." } \\
\text { "A empresa investe em treinamento dentro da unidade e em } \\
\text { visitas técnicas para outras unidades, inclusive fora do país." } \\
\text { "Segurança é um valor forte. Sustentabilidade é outro. E todos } \\
\text { já entendem isso." }\end{array}$ \\
\hline \multicolumn{3}{|c|}{ utora, com base nos dados da pesquisa. } \\
\hline
\end{tabular}

Oriunda de uma espécie de assentamento do governo, Canaã dos Carajás não tem cultura de mineração. A cultura agrícola e pecuária, sem grandes responsabilidades ambientais é o legado encontrado, de acordo com os dados das entrevistas.

As questões como a gestão de pessoas facilita ou dificulta a obtenção do comprometimento organizacional nessa unidade, bem como a existência de diferenças da cultura e como elas se evidenciam são respondidas nos parágrafos subseqüentes. 
Os entrevistados afirmaram que a parceria da Vale com a prefeitura de Canaã é um projeto de sustentabilidade digno de ser visto por outras unidades como um modelo a ser seguido. A retenção dos talentos na unidade depende dos desafios de crescimento. Esses desafios são altos. As pessoas são mais jovens e assumem responsabilidades mais rapidamente. A preparação para que elas possam fazer isso é contínua. A garantia de mais crescimento, em função dos novos projetos na região, é dada porque a operacionalização da unidade de Canaã deu certo e abriu portas para novas unidades instalarem-se em futuro próximo. Isso também contribui para facilitar a relação da empresa com a comunidade e diminui os problemas de adaptação à estrutura local.

Trazer pessoas de fora requer estrutura muito atrativa, na qual se incluem todas as condições para a acomodação das famílias. As entrevistas mostram que pessoas que vêm de outras regiões do país têm adaptação mais complexa. Entretanto, os cargos mais estratégicos ainda exigem que a prática seja a de investir nessa estrutura de deslocar pessoas de outras regiões. Formar e qualificar a mão-de-obra regional, com todo o risco de perdê-la, ainda é considerado o mais adequado e que poderá vir a solucionar esse problema de adaptação. São criadas parcerias com Escolas Técnicas, Universidade Federal e SENAI.

Os cursos de Engenharia de Minas, Geologia e Meio-ambiente da UFPA, em Marabá, são fontes de preparação e captação das pessoas. Há oferta de estágios para os estudantes desses cursos, como prática de gestão adotada para criar aproximação com a comunidade regional que está sendo formada. O compartilhamento de responsabilidades é uma outra forma de preparação. O programa de aprendizes prepara a mão-de-obra regional com a visão de obter promoções até os cargos gerenciais, notadamente supervisão.

Como o maior desafio da unidade é atrair e reter talentos, o pacote de benefício é considerado mais agressivo para comportar tal desafio nessa fase em que as pessoas da região ainda estão sendo formadas. Há o programa de preparação dos líderes, voltado para desenvolvimento de pessoas. Ficou evidenciado que as pessoas contribuem essencialmente porque elas querem contribuir. Elas sentem gratidão pelo que a estrutura proporciona para elas e para a região. Essa estrutura, por sua vez, contribui com a naturalidade hierárquica, com a confiança depositada nas mãos de quem dirige equipamentos complexos, com o conforto proporcionado nesses equipamentos, com a forma de obter resultados respeitando o meio-ambiente, as pessoas e a diversidade cultural. As pessoas dão o melhor de si e os resultados espelham isso. 
O sistema de avaliação incentiva e premia a participação e a atuação do indivíduo no trabalho em equipe nessa unidade remota. Em função das altas taxas de crescimento da empresa a participação ativa dos indivíduos propicia um ambiente mais favorável à sua integração, com treinamento, capacitação e/ou integração funcional, bem como contribui para o aporte, por parte dos novos entrantes, de um olhar diferenciado para as práticas e processos da corporação nessa unidade.

$\mathrm{O}$ orgulho e o empenho exercido pelos indivíduos em favor da organização são latentes. $\mathrm{O}$ orgulho das pessoas da região está relacionado à valorização e a esse preparo proporcionado pela unidade. A expressão do orgulho das pessoas que vêm de fora se vincula ao desafio de formar jovens inexperientes, vendo-os progredir passo-a-passo.

Para os entrevistados, o empenho caminha junto com o orgulho. Quanto mais as pessoas se empenham, mais elas sentem orgulho pelo que vêem acontecer. Sossego é a única mina de cobre da Vale e isso também é motivo de orgulho. Quanto mais elas se orgulham mais se comprometem com os resultados. O comprometimento é resultante: do fato de as pessoas desejarem brilhar; da estrutura da unidade prepará-las bem e valorizá-las; da possibilidade de ascensão na própria estrutura. A unidade também estimula os seus empregados a darem contribuição, por intermédio de fóruns adequados, entre eles a reunião de gestão participativa e os programas de CCQ's.

O envolvimento das equipes na superação de todos os obstáculos caminha junto com o comprometimento. Essa unidade tem criado uma forma peculiar de conscientizar as pessoas para os valores de segurança, meio-ambiente, qualidade e sustentabilidade. O incentivo à participação, ao envolvimento e ao engajamento dos empregados aos objetivos organizacionais ocorre no dia-a-dia, ao longo das reuniões e/ou execução de projetos e tarefas.

Visão, filosofia de atuação e valores organizacionais são considerados bem difundidos e internalizados, em sua essência, de acordo com os entrevistados. Foi reforçado que há humildade e respeito por trás do orgulho e as pessoas reconhecem os investimentos realizados pela unidade. Em razão desse reconhecimento, considera-se melhor transferir os talentos que não se adaptam à região do que perdê-los. Elucide-se que os dados da pesquisa mostram chefias e colegas de todas as áreas e/ou da mesma área estimulando: feedbacks, debates, cooperação, valorização do trabalho, reconhecimento pela capacidade de desenvolvimento, 
confiabilidade e colaboração. Nesse ponto dá-se o cruzamento dos aspectos ligados a comportamento, comprometimento, gestão de pessoas e cultura organizacional, detalhados no quadro $\mathrm{n}^{\circ} .14$ para essa unidade.

Foram constatadas diferenças e semelhanças entre as unidades desse caso. Elas estão condensadas na ilustração $n^{\circ} 02$.

\section{ILUSTRAÇÃO №. 02 \\ DIFERENÇAS E SEMELHANÇAS ENTRE UNIDADES CASO 4. 1. VALE}

\begin{tabular}{|c|c|c|c|}
\hline $\begin{array}{l}\text { Canaã dos Carajás } \\
\text { Unidade nova, moradias inseridas na } \\
\text { comunidade; } \\
\text { Projeto de sustentabilidade em parceria com } \\
\text { as prefeituras; } \\
\text { Cultura de mineração é nova na cidade. }\end{array}$ & \multicolumn{2}{|c|}{$\begin{array}{l}\text { Paragominas } \\
\text { Concepção de adaptações e melhorias da } \\
\text { infra-estrutura existente na cidade; } \\
\text { Programa de aprendizes envolvendo jovens } \\
\text { nascidos na cidade; } \\
\text { Reeducação da cultura local, com relação ao } \\
\text { meio-ambiente; } \\
\text { Remuneração variável considerada compe- } \\
\text { titiva e privilegiada. }\end{array}$} & $\begin{array}{l}\text { Carajás } \\
\text { Unidade antiga moradia na vila e em } \\
\text { Parauapebas; } \\
\text { Diferencial na capacidade de mobilização } \\
\text { das pessoas; } \\
\text { Parcerias com o governo do estado e outras } \\
\text { empresas privadas para ações de desenvol- } \\
\text { vimento. }\end{array}$ \\
\hline \multicolumn{4}{|c|}{ SEMELHANÇAS } \\
\hline \multicolumn{2}{|c|}{$\begin{array}{l}\text { Porto Trombetas } \\
\text { A unidade é responsável pela criação e manutenção de toda a sua } \\
\text { infra-estru-tura; } \\
\text { A unidade tem a autonomia para lidar com as suas especificidades e } \\
\text { tem uma cultura própria, adaptada à realidade do local; } \\
\text { É uma associação de empresas nacionais e internacionais; } \\
\text { Visitas dos familiares às áreas operacionais é uma especificidade já } \\
\text { premiada; } \\
\text { Treinamento para aposentáveis aprenderem a viver fora da unida-de } \\
\text { e da comunidade. }\end{array}$} & \multicolumn{2}{|c|}{$\begin{array}{l}\text { Itabira } \\
\text { Parceria com a secretaria de Educação para instalação de uma } \\
\text { unidade da Universidade Federal, com a perspectiva de completar o } \\
\text { ciclo educacional em graduação e pós-graduação, de modo a } \\
\text { preparar as pessoas na própria localidade; } \\
\text { Mudança de cultura de competição para colaboração. }\end{array}$} \\
\hline
\end{tabular}

Fonte: a autora, com base nos dados da pesquisa.

As semelhanças mostram os traços que unem as pessoas, em todas essas regiões, em torno do mesmo propósito: reter talentos nas unidades com estruturas organizacionais remotas nessa empresa.

As diferenças denotam os aspectos ligados a comportamento, comprometimento, gestão de pessoas e cultura organizacional, em interação para a consecução desse propósito nessas unidades. 
O dinamismo e as taxas de crescimento da empresa provocam uma necessidade de facilitar o processo de crescimento dentro das cinco unidades e aproveitar as oportunidades criadas: treinamento, crescimento profissional, conhecimento de novas realidades, como morar em outras regiões para fazer rodízios e trocar experiências. Os indivíduos esforçam-se para fazer jus a essas oportunidades, acreditando na meritocracia, cultura existente nesse caso 4.1.

\section{2 Caso CADAM / Pará Pigmentos}

A Caulim da Amazônia S.A. - CADAM e a Pará Pigmentos S.A. - PPSA fornecem caulins finos e delaminados para a indústria mundial de papéis e cartões revestidos.

A CADAM é produtora e exportadora de caulim para revestimento de papéis e cartões do Brasil e tem suas operações de mineração, industrialização e embarque localizadas às margens do rio Jari, divisa dos Estados do Pará e Amapá, na Região Norte. A empresa iniciou suas atividades em 1971, tendo passado à esfera da CAEMI em 1991.

A Pará Pigmentos é uma empresa brasileira produtora de pigmentos à base de caulim, com estrutura operacional integrada, que engloba as atividades de mineração, industrialização e embarque. A empresa deu início às suas operações em 1996.

A CADAM tem significativas vantagens competitivas: excelência operacional, logística privilegiada e grande volume de reservas. Suas vendas representam cerca de $9 \%$ do mercado mundial de caulim para revestimento de papel. A empresa possui instalações no Brasil e na Bélgica e mina própria situada no Norte do Brasil, com qualidades reconhecidas internacionalmente.

A Pará Pigmentos também é suportada por jazidas de classe mundial em termos de qualidade, tamanho e flexibilidade, localizadas na bacia do Rio Capim, no Norte do Brasil.

Com estrutura comercial própria nos principais mercados do mundo, CADAM e PPSA ocupam posições de destaque no cenário internacional, atendendo aos maiores grupos papeleiros mundiais, devido à qualidade dos seus produtos e à logística diferenciada que permite a regularidade no fornecimento. 
O modelo de gestão busca fazer mais e melhor pelo meio-ambiente, usando os recursos naturais de forma sustentável, gerando menos resíduos, valorizando e trabalhando a educação ambiental dentro e fora da empresa.

CADAM e PPSA, companhias de mineração, beneficiamento e comercialização de caulim para os mercados externo e interno têm como política de gestão os seguintes princípios: "atender à legislação e normas aplicáveis à suas atividades e aos seus produtos e serviços; cumprir os compromissos assumidos com clientes, acionistas, colaboradores, fornecedores, órgãos governamentais e comunidades; aumentar a competitividade através do aprimoramento dos processos, visando a qualidade do produto, a prevenção da poluição, dos impactos ambientais e dos riscos ocupacionais de seus colaboradores diretos e indiretos; promover o desenvolvimento e a capacitação dos colaboradores; monitorar o sistema de gestão, através do estabelecimento de objetivos e metas para melhorias contínuas e acompanhamento permanente de seu cumprimento."

Seus valores envolvem: proteção ao meio-ambiente; promoção da saúde e segurança dos empregados e familiares; respeito e promoção do bem-estar das populações vizinhas; postura ética e cidadã através da transparência das intenções e ações para com a sociedade; e qualidade. Seu Sistema Integrado de Melhorias - SIM é para a empresa inteira e "é uma forma de agir que busca a mudança de comportamento das pessoas.”

\section{2. 1 Unidade: Ipixuna - Minério Caulim}

Ipixuna é um município brasileiro localizado no nordeste do Estado do Pará. A unidade Ipixuna é considerada remota, isolada e confinada. Sua atividade de extração de caulim dá-se em mina a céu aberto. Seu acesso ocorre por estrada de caulim, com travessia de balsa pelo rio Capim.

Não existe núcleo residencial, onde os funcionários residam com as suas famílias. Existem os alojamentos: gerenciais, administrativos e operacionais. A infra-estrutura dos alojamentos é considerada boa, com espaços para lazer, exercícios físicos, alimentação e descanso, além de caminhadas em contato com a natureza. 
O turno de trabalho do administrativo é normal e as pessoas podem se deslocar para suas casas aos finais de semana se desejarem. O turno do operacional obedece ao regime de $15 \mathrm{x}$ 15 , no qual eles ficam quinze dias consecutivos nos alojamentos e quinze dias de folga, com os familiares em seus locais de origem.

O quadro $\mathrm{n}^{\mathrm{o}}$. 16 mostra o resultado da análise de conteúdo das dezesseis entrevistas realizadas nessa unidade.

\begin{tabular}{|c|c|c|c|}
\hline \multicolumn{4}{|c|}{$\begin{array}{l}\text { QUADRO No.16 } \\
\text { RESULTADO DA ANÁLISE DE CONTEÚDO UNIDADE IPIXUNA }\end{array}$} \\
\hline \multirow{2}{*}{$\begin{array}{l}\text { Unidade de Codificação } \\
\text { Palavras-tema }\end{array}$} & \multirow[t]{2}{*}{ Palavras-chave ou Frases-chave } & \multicolumn{2}{|c|}{ Contagem } \\
\hline & & Presença & Ausência \\
\hline 1. Feedback & $\begin{array}{l}\text { Estímulo; } \\
\text { Evidência. }\end{array}$ & $\begin{array}{l}09 \\
16 \\
\end{array}$ & $\begin{array}{c}07 \\
-\end{array}$ \\
\hline 2. Interações & Integrantes dos diversos escalões. & 14 & 02 \\
\hline 3. Abertura & $\begin{array}{l}\text { Encorajamento para debates; } \\
\text { Ocorrência de debates. }\end{array}$ & $\begin{array}{l}12 \\
16\end{array}$ & $\begin{array}{c}04 \\
-\end{array}$ \\
\hline 4. Comunicações interpessoais & Ocorrência entre as áreas. & 15 & 01 \\
\hline 5. Emoções & Expressão. & 09 & 07 \\
\hline 6. Pensar, sentir e agir & Evidência de interface. & 10 & 06 \\
\hline 7. Tomada de decisão & Ocorrência de em grupo. & 10 & 06 \\
\hline 8. Comportamento intergrupal & Favorecendo o trabalho em equipe. & 14 & 02 \\
\hline 9. Participação & Estímulo à atitude de participação do empregado. & 14 & 02 \\
\hline 10. Envolvimento & $\begin{array}{l}\text { Estímulo à atitude de envolvimento do empregado } \\
\text { com os objetivos organizacionais. }\end{array}$ & 16 & - \\
\hline 11. Comprometimento & $\begin{array}{l}\text { Estímulo à atitude de comprometimento } \\
\text { (identificação) do empregado com os objetivos } \\
\text { organizacionais. }\end{array}$ & 13 & 03 \\
\hline 12. Expectativas & $\begin{array}{l}\text { Possibilidade de o empregado comunicar expecta- } \\
\text { tivas em relação à unidade; } \\
\text { Ocorrência de comunicação das expectativas da } \\
\text { organização em relação ao empregado. }\end{array}$ & $\begin{array}{l}06 \\
09\end{array}$ & $\begin{array}{l}10 \\
07\end{array}$ \\
\hline 13. Responsabilidades & $\begin{array}{l}\text { Estímulo para o empregado assumir responsabi- } \\
\text { lidades sobre suas ações. }\end{array}$ & 13 & 03 \\
\hline 14. Engajamento & $\begin{array}{l}\text { Estímulo para o engajamento das pessoas aos } \\
\text { objetivos e metas organizacionais. }\end{array}$ & 16 & - \\
\hline 15. Características da unidade & $\begin{array}{l}\text { Estimulando as pessoas a despenderem esforços } \\
\text { para nela permanecerem. }\end{array}$ & 06 & 10 \\
\hline 16. Cooperação & $\begin{array}{l}\text { Estímulo à atitude de cooperação; } \\
\text { Evidência da cooperação. }\end{array}$ & $\begin{array}{l}12 \\
16\end{array}$ & $\begin{array}{c}04 \\
-\end{array}$ \\
\hline 17. Valorização & $\begin{array}{l}\text { Evidência da valorização de opiniões e descobertas } \\
\text { em relação à maneira de se obter resultados; } \\
\text { Evidência da valorização do trabalho. }\end{array}$ & 14 & 02 \\
\hline 18. Aprendizagem/reaprendizagem & $\begin{array}{l}\text { Reconhecimento da necessidade de apren- } \\
\text { dizagem/reaprendizagem em relação ao trabalho. }\end{array}$ & 09 & 07 \\
\hline 19. Desenvolvimento & $\begin{array}{l}\text { Demonstração do estímulo ao desenvolvimento } \\
\text { pessoal e profissional na própria organização. }\end{array}$ & 09 & 07 \\
\hline 20. Incentivos & $\begin{array}{l}\text { Disponibilização de incentivos vinculados a } \\
\text { resultados obtidos pela equipe. }\end{array}$ & 08 & 08 \\
\hline 21. Reconhecimento & $\begin{array}{l}\text { As pessoas são capazes de: desenvolvimento, } \\
\text { confiança e colaboração. }\end{array}$ & 16 & - \\
\hline $\begin{array}{l}\text { 22. Características organizacionais } \\
\text { da unidade }\end{array}$ & $\begin{array}{l}\text { Atrair e reter pessoas de alto potencial e qualifi- } \\
\text { cação para o trabalho. }\end{array}$ & 05 & 11 \\
\hline
\end{tabular}




\begin{tabular}{|c|c|c|c|}
\hline \multirow{2}{*}{$\begin{array}{l}\text { Unidade de Codificação } \\
\text { Palavras-tema }\end{array}$} & \multirow[t]{2}{*}{ Palavras-chave ou Frases-chave } & \multicolumn{2}{|c|}{ Contagem } \\
\hline & & Presença & Ausência \\
\hline $\begin{array}{l}\text { 23. Criação de condições de trabalho } \\
\text { na unidade }\end{array}$ & $\begin{array}{l}\text { Favoráveis à manutenção da motivação individual } \\
\text { para o trabalho; } \\
\text { Favoráveis à mobilização dos grupos em torno das } \\
\text { metas organizacionais. }\end{array}$ & 04 & $\begin{array}{l}12 \\
02\end{array}$ \\
\hline $\begin{array}{l}\text { 24. Estrutura organizacional da } \\
\text { unidade }\end{array}$ & $\begin{array}{l}\text { Valorizando somente o que a liderança determina; } \\
\text { Valorizando a iniciativa individual; } \\
\text { Valorizando o poder concentrado na liderança; } \\
\text { Valorizando a responsabilidade compartilhada. }\end{array}$ & $\begin{array}{l}04 \\
10 \\
08 \\
12\end{array}$ & $\begin{array}{l}12 \\
06 \\
08 \\
04\end{array}$ \\
\hline 25. Comunicação & $\begin{array}{l}\text { Acerca do que é esperado do desempenho das } \\
\text { pessoas; } \\
\text { Dos acontecimentos críticos que marcam a história } \\
\text { da unidade; } \\
\text { Ocupação da unidade em saber como está sendo } \\
\text { percebido o seu processo de comunicação formal e } \\
\text { informal. }\end{array}$ & $\begin{array}{l}08 \\
13 \\
09\end{array}$ & $\begin{array}{l}08 \\
03 \\
07\end{array}$ \\
\hline 26. Missão organizacional & $\begin{array}{l}\text { Ocupação da unidade em saber como está sendo } \\
\text { compreendida sua missão. }\end{array}$ & 08 & 08 \\
\hline 27. Valores & $\begin{array}{l}\text { Demonstração dos valores pelos quais se rege a } \\
\text { unidade; } \\
\text { Comunicação e/ou constatação, pelos empregados, } \\
\text { da coerência entre os valores e o sistema de gestão } \\
\text { da unidade. }\end{array}$ & $\begin{array}{l}13 \\
13\end{array}$ & 03 \\
\hline 28. Políticas & $\begin{array}{l}\text { Criação das condições de adaptação de políticas } \\
\text { integradas de recursos humanos à realidade da } \\
\text { organização e ao seu contexto de atuação nessa } \\
\text { unidade remota. }\end{array}$ & 09 & 07 \\
\hline
\end{tabular}

As unidades de codificação 1 a 8 dizem respeito às palavras-tema contidas nos aspectos do comportamento organizacional. A contagem de presenças totalitárias nas unidades de codificação 1 (palavra-chave 2) e 3 (frase-chave 2), seguida de presenças expressivas nas unidades 2, 4 e 8 e significativas nas unidades 3 (palavra-chave 1), 6 e 7, mostra uma visão favorável dos entrevistados em relação aos aspectos ligados ao comportamento organizacional.

As ausências contidas nas palavras-tema 1 (palavra-chave 1), 5, 6 e 7 não são desprezíveis e podem ser conduzidas a um diálogo investigativo das razões.

As unidades de codificação 9 a 16 estão voltadas para as palavras-tema contidas nos aspectos do comprometimento organizacional. A contagem de presenças é totalitária nas unidades de codificação 10, 14, e 16 (frase-chave 2) e expressiva nas unidades de codificação 9,11, 13 e 16 (frase-chave 1) o que denota a grande favorabilidade, na percepção dos entrevistados, com relação a esses aspectos voltados para o comprometimento. 
As unidades de codificação 12, em ambas as frases-chave e 15, mostram que as ausências são significativas e necessitam de investigação das razões que estão nelas embutidas.

As unidades de codificação 17 a 23 referem-se às palavras-tema contidas nos aspectos de gestão estratégica de pessoas. As presenças são totalizadoras nas unidades de codificação 17 (frase-chave 2) e 21; quase totalizadoras nas 17 (frase-chave 1) e 23 (frase-chave 2).

As ausências observadas nas unidades de codificação 18, 19, 20, 22 e 23 (frase-chave 1) denotam necessidade de investigação para a compreensão das razões.

As unidades de codificação 24 a 28 estão no bojo das palavras-tema contidas nos aspectos da cultura organizacional. Registre-se, nesse quadro, a ausência encontrada na unidade de codificação 24 - estrutura organizacional da unidade, com a frase-chave "valorizando somente o que a liderança determina", mostrando o aspecto positivo da falta de centralização do valor nas determinações oriundas somente das lideranças, o que é reforçado pela presença significativa da frase-chave "valorizando a responsabilidade compartilhada".

Ainda nessa mesma unidade de codificação, encontram-se presença substancial e ausência não desprezível da frase-chave "valorizando a iniciativa individual". A divisão exata entre presença e ausência na frase-chave "valorizando o poder concentrado na liderança" volta a chamar a atenção para a necessidade de investigação das razões contidas nesses resultados.

As unidades de codificação 25 (frases-chave 1 e 3), 26 e 28 apresentam ausências substanciais, podendo denotar necessidade de investigação das prováveis causas dessas ausências, na medida em que elas podem indicar percepções desfavoráveis, na visão dos entrevistados, no que tange aos aspectos concernentes à cultura organizacional dessa unidade remota.

O quadro $\mathrm{n}^{\mathrm{o}} .17$ apresenta o resultado da análise de conteúdo aplicadado ao escopo da pesquisa nessa unidade remota e contribui para aprofundar a compreensão do que foi mostrado no quadro $\mathrm{n}^{\mathrm{o}} .16$. 


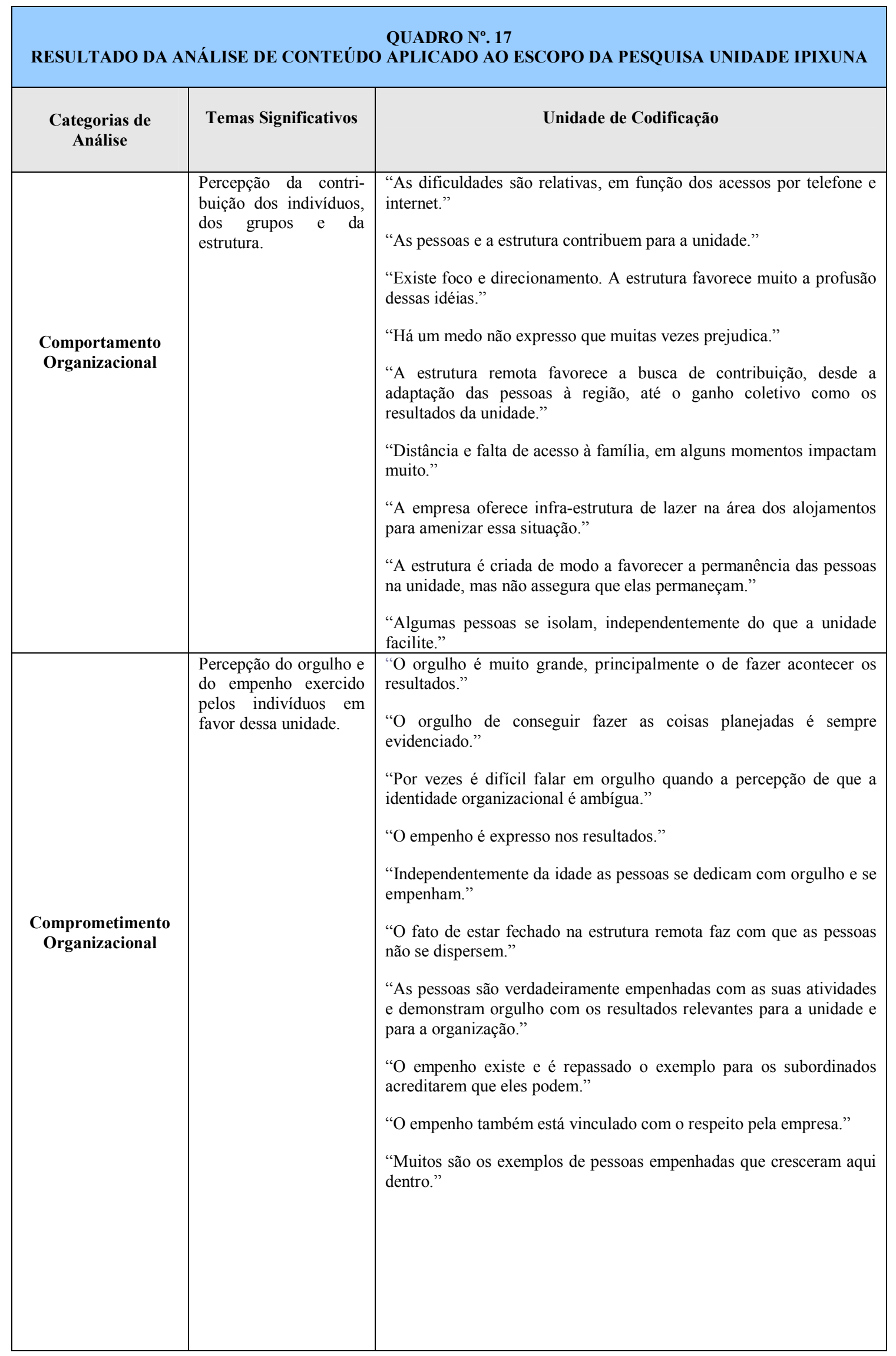




\begin{tabular}{|c|c|c|}
\hline $\begin{array}{l}\text { Categorias de } \\
\text { Análise }\end{array}$ & Temas Significativos & Unidade de Codificação \\
\hline $\begin{array}{c}\text { Gestão Estratégica } \\
\text { de Pessoas }\end{array}$ & $\begin{array}{l}\text { Percepção da adoção de } \\
\text { novas práticas de } \\
\text { gestão, de modo a } \\
\text { facilitar as ações de } \\
\text { desenvolvimento e } \\
\text { resolução de conflitos } \\
\text { nessa unidade remota. }\end{array}$ & $\begin{array}{l}\text { "Não há percepção de novas práticas de gestão no geral. Fica } \\
\text { dependendo do diálogo de cada gestor, tanto no que diz respeito à } \\
\text { forma de gestão que facilita o desenvolvimento, quanto no que se } \\
\text { refere à resolução de conflitos." } \\
\text { "São adotadas novas práticas de gestão, mas elas precisam ser mais } \\
\text { simples, de modo a impedir que o controle volte a ser excessivo." } \\
\text { "O incentivo à continuidade dos estudos é uma prática positiva." } \\
\text { "As equipes de melhorias contínuas são práticas facilitadoras e geram } \\
\text { desenvolvimento." } \\
\text { "A resolução de conflitos é facilitada pelo diálogo entre os envolvidos. } \\
\text { Por estarem confinadas às vezes as pessoas agem sem pensar." } \\
\text { "O que é perceptível é que, tanto elogios quanto conversas a respeito } \\
\text { do que há de bom na unidade estimulam as ações de } \\
\text { desenvolvimento." } \\
\text { "A empresa poderia buscar novas formas de desenvolver as pessoas na } \\
\text { unidade, de modo a diminuir conflitos hoje existentes entre as áreas, } \\
\text { em meio à união das pessoas. A gestão pode aprimorar isso." } \\
\text { "As práticas adotadas de gestão, necessariamente precisam estar em } \\
\text { linha com o desenvolvimento das pessoas e com a melhor forma de } \\
\text { resolver os conflitos." }\end{array}$ \\
\hline $\begin{array}{c}\text { Cultura } \\
\text { Organizacional }\end{array}$ & $\begin{array}{l}\text { Percepção do co- } \\
\text { nhecimento que os } \\
\text { indivíduos têm, acerca } \\
\text { da visão, filosofia de } \\
\text { atuação, missão e } \\
\text { valores nessa unidade } \\
\text { remota. }\end{array}$ & $\begin{array}{l}\text { "Houve muito conflito na união entre as duas empresas." } \\
\text { "Atualmente, não obstante os ajustes existe a calmaria." } \\
\text { "As pessoas têm bastante conhecimento acerca da visão, da filosofia } \\
\text { de atuação, da missão e dos valores da unidade, por intermédio de } \\
\text { todos os programas internos desde o treinamento introdutório." } \\
\text { "As divulgações são feitas por diversificados canais. As pessoas } \\
\text { assimilam bem e podem tirar dúvidas a qualquer momento." }\end{array}$ \\
\hline & & \\
\hline
\end{tabular}

Por tratar-se de uma unidade remota isolada e confinada, na maior parte do tempo a interação fica favorecida em função da convivência. As pessoas e os grupos acabam usufruindo aspectos da estrutura para o alcance dos resultados da unidade e das relações intepessoais. Ficou o sentimento, entre os entrevistados, de que as pessoas não estavam preparadas para a união das duas empresas e houve muito conflito. Há, também, o reconhecimento de um bom trabalho, promovido para o momento ser entendido.

A estrutura física de Ipixuna é tida como boa, necessitando de recuperação de alguns equipamentos industriais. Existem pessoas que influenciam e suas opiniões são respeitadas. A estrutura favorece a vida no local remoto e isolado. Opções de lazer, alimentação, salões de beleza, saúde, alojamento são oferecidas por essa estrutura. 
Os entrevistados consideram que as pessoas, os grupos e a estrutura podem favorecer ou desfavorecer a convivência na unidade, a depender de como se lida com as carências criadas pelo isolamento/confinamento.

As questões como a gestão de pessoas facilita ou dificulta a obtenção do comprometimento organizacional nessa unidade, bem como a existência de diferenças da cultura e de como elas se evidenciam são respondidas nos parágrafos subseqüentes.

Os dados das entrevistas mostram que estar longe de casa, não obter feedback constante e ter reconhecimento financeiro abaixo da expectativa, ocasionalmente embotam o orgulho. Todavia, a unidade aproxima as pessoas pela estrutura de moradia e aí reside a resposta às informações sobre os níveis de satisfação. As ações que denotam o orgulho surgem dessa aproximação.

No que tange à questão de gestão de pessoas, é reconhecido que o fato de estar em estrutura remota leva ao contato pessoal e pode influenciar no aumento do conhecimento de tudo o que é divulgado pela empresa, a qual é percebida como geradora de condições de crescimento e qualificação das pessoas, por intermédio de seminários externos, palestras com pessoas trazidas para essa finalidade, treinamentos, reuniões e debates, confrontações para resolver conflitos, sempre com a presença dos líderes das áreas envolvidas, o que leva à percepção de transparência das ações.

Em Ipixuna, os empregados têm a oportunidade de continuar seus estudos, graças ao Centro de Educação Continuada (CEC), desenvolvido dentro da unidade. De janeiro a novembro, empregados próprios e de empresas contratadas participam das aulas da alfabetização até o ensino médio. A demanda por matrícula e a contagem de presenças às aulas têm sido consideradas excelentes nos últimos anos. No mesmo município, a empresa desenvolve também programas de educação ambiental, apoio à produção, à informática e às instituições de saúde.

Não obstante algumas ferramentas de gestão serem utilizadas no sentido de verificar pontos fortes e fracos, reina a percepção de que falta, aos gestores, desenvolverem as condições de utilização desses diagnósticos em prol da unidade. 
Para os entrevistados, a forma de gestão necessita ser o foco da preocupação. Os gestores precisam estar mais em contato com as equipes, no cotidiano e mais integrados entre si. A resolução de conflitos tem sido tratada com treinamentos em feedbacks, mas é expresso o desejo de que passe a acontecer como um exercício natural.

A expressão diária das idéias favorece a superação dos obstáculos, a implantação de melhorias e o alcance das metas pré-estabelecidas. O empenho também está vinculado a essas questões.

Os dados das entrevistas, no entanto, mostram a possibilidade do empenho ser oriundo do orgulho pessoal em fazer bem as atividades. Mostram, também, que a empresa/unidade quer elevar a questão do orgulho, voltar aos níveis outrora existentes, mas, no momento atual, a unidade não é determinante na obtenção do comprometimento organizacional.

O empenho é percebido na forma com que as pessoas buscam o espaço para desenvolver o trabalho e criar condições de melhorias. A estrutura é considerada sempre apoiadora, quer sejam percebidos os resultados ou não. Contudo, é constatada pelos dados das entrevistas, falta de autonomia com relação ao processo decisório, centralizado na concentração gerencial em Barcarena e a distância física dos gestores é sentida pelas equipes de trabalho.

Ainda de acordo com a opinião dos entrevistados, há um grande comprometimento das pessoas para fazer com que a unidade aconteça e o negócio cresça. Elas sempre buscam soluções para os problemas dessa unidade. Para esses entrevistados, os problemas que precisam ser resolvidos são de fácil solução em razão do companheirismo existente. As pessoas não medem esforços e são bem unidas para alcançar os objetivos.

Registre-se que, os dados da pesquisa, nessa unidade, ainda que não sejam os ideais para os entrevistados, mostram chefias e colegas de todas as áreas e/ou da mesma área estimulando: feedbacks, debates, cooperação, valorização do trabalho, reconhecimento pela capacidade de desenvolvimento, confiabilidade e colaboração. Nesse ponto dá-se o cruzamento dos aspectos ligados a comportamento, comprometimento, gestão de pessoas e cultura organizacional, detalhados no quadro $\mathrm{n}^{\circ} .16$. 


\section{2. 2 Unidade: Monte Dourado - Minério Caulim}

Monte Dourado dista $95 \mathrm{~km}$ ao Sul da Linha do Equador. É distrito do município de Almeirim, Pará, situado às margens do rio Amazonas. Cerca de $600 \mathrm{~km}$ de Monte Dourado, em terras do Pará, encontra-se o Parque Indígena Tumucumaque, onde vivem três mil índios da tribo Aparaís, descendentes de Tupis.

Situada às margens do rio Jari, divisa dos Estados do Pará e Amapá, Região Norte, localiza-se a unidade Monte Dourado, com o terminal Munguba. Foi criado o núcleo residencial, onde os funcionários residem com as suas famílias. Monte Dourado é considerada uma unidade remota isolada e confinada.

Seu acesso dá-se pelo rio Jari e pelo aeroporto da Jari Celulose. Sua atividade de extração de caulim acontece em mina a céu aberto. $\mathrm{O}$ quadro $\mathrm{n}^{\circ} .18$ mostra o resultado da análise de conteúdo das doze entrevistas realizadas nessa unidade.

\begin{tabular}{|c|c|c|c|}
\hline \multicolumn{4}{|c|}{$\begin{array}{c}\text { QUADRO No.18 } \\
\text { RESULTADO DA ANÁLISE DE CONTEÚDO UNIDADE MONTE DOURADO }\end{array}$} \\
\hline \multirow{2}{*}{$\begin{array}{l}\text { Unidade de Codificação } \\
\text { Palavras-tema }\end{array}$} & \multirow[t]{2}{*}{ Palavras-chave ou Frases-chave } & \multicolumn{2}{|c|}{ Contagem } \\
\hline & & Presença & Ausência \\
\hline 1. Feedback & $\begin{array}{l}\text { Estímulo; } \\
\text { Evidência. }\end{array}$ & $\begin{array}{l}10 \\
12\end{array}$ & $\begin{array}{l}02 \\
-\end{array}$ \\
\hline 2. Interações & Integrantes dos diversos escalões. & 10 & 02 \\
\hline 3. Abertura & $\begin{array}{l}\text { Encorajamento para debates; } \\
\text { Ocorrência de debates. }\end{array}$ & $\begin{array}{l}09 \\
10\end{array}$ & $\begin{array}{l}03 \\
02\end{array}$ \\
\hline 4. Comunicações interpessoais & Ocorrência entre as áreas. & 10 & 02 \\
\hline 5. Emoções & Expressão. & 06 & 06 \\
\hline 6. Pensar, sentir e agir & Evidência de interface. & 08 & 04 \\
\hline 7. Tomada de decisão & Ocorrência de em grupo. & 10 & 02 \\
\hline 8. Comportamento intergrupal. & Favorecendo o trabalho em equipe. & 10 & 02 \\
\hline 9. Participação & Estímulo à atitude de participação do empregado. & 11 & 01 \\
\hline 10. Envolvimento & $\begin{array}{l}\text { Estímulo à atitude de envolvimento do empregado } \\
\text { com os objetivos organizacionais. }\end{array}$ & 11 & 01 \\
\hline 11. Comprometimento & $\begin{array}{l}\text { Estímulo à atitude de comprometimento } \\
\text { (identificação) do empregado com os objetivos } \\
\text { organizacionais. }\end{array}$ & 10 & 02 \\
\hline 12. Expectativas & $\begin{array}{l}\text { Possibilidade de o empregado comunicar expecta- } \\
\text { tivas em relação à unidade. } \\
\text { Ocorrência de comunicação das expectativas da } \\
\text { unidade em relação ao empregado. }\end{array}$ & 08 & 04 \\
\hline 13. Responsabilidades & $\begin{array}{l}\text { Estímulo para o empregado assumir responsabili- } \\
\text { dades sobre suas ações. }\end{array}$ & 10 & 02 \\
\hline 14. Engajamento & $\begin{array}{l}\text { Estímulo para o engajamento das pessoas aos } \\
\text { objetivos e metas organizacionais. }\end{array}$ & 12 & - \\
\hline 15. Características da unidade & $\begin{array}{l}\text { Estimulando as pessoas a despenderem esforços } \\
\text { para nela permanecerem. }\end{array}$ & 09 & 03 \\
\hline 16. Cooperação & $\begin{array}{l}\text { Estímulo à atitude de cooperação; } \\
\text { Evidência da cooperação. }\end{array}$ & $\begin{array}{l}10 \\
12\end{array}$ & $\begin{array}{c}02 \\
-\end{array}$ \\
\hline
\end{tabular}




\begin{tabular}{|c|c|c|c|}
\hline \multirow{2}{*}{$\begin{array}{l}\text { Unidade de Codificação } \\
\text { Palavras-tema }\end{array}$} & \multirow[t]{2}{*}{ Palavras-chave ou Frases-chave } & \multicolumn{2}{|c|}{ Contagem } \\
\hline & & Presença & Ausência \\
\hline 17. Valorização & $\begin{array}{l}\text { Evidência da valorização de opiniões e descobertas } \\
\text { em relação à maneira de se obter resultados; } \\
\text { Evidência da valorização do trabalho. }\end{array}$ & $\begin{array}{l}09 \\
12\end{array}$ & 03 \\
\hline 18. Aprendizagem/reaprendizaem & $\begin{array}{l}\text { Reconhecimento da necessidade de apren- } \\
\text { dizagem/reaprendizagem em relação ao trabalho. }\end{array}$ & 11 & 01 \\
\hline 19. Desenvolvimento & $\begin{array}{l}\text { Demonstração do estímulo ao desenvolvimento } \\
\text { pessoal e profissional na própria organização. }\end{array}$ & 10 & 02 \\
\hline 20. Incentivos & $\begin{array}{l}\text { Disponibilização de incentivos vinculados a resul- } \\
\text { tados obtidos pela equipe. }\end{array}$ & 08 & 04 \\
\hline 21. Reconhecimento & $\begin{array}{l}\text { As pessoas são capazes de: desenvolvimento, } \\
\text { confiança e colaboração. }\end{array}$ & 12 & - \\
\hline $\begin{array}{l}\text { 22. Características organizacionais } \\
\text { da unidade }\end{array}$ & $\begin{array}{l}\text { Atrair e reter pessoas de alto potencial e qualifi- } \\
\text { cação para o trabalho. }\end{array}$ & 08 & 04 \\
\hline $\begin{array}{l}\text { 23. Criação de condições de trabalho } \\
\text { na unidade }\end{array}$ & $\begin{array}{l}\text { Favoráveis à manutenção da motivação individual } \\
\text { para o trabalho; } \\
\text { Favoráveis à mobilização dos grupos em torno das } \\
\text { metas organizacionais. }\end{array}$ & $\begin{array}{l}06 \\
10\end{array}$ & 06 \\
\hline $\begin{array}{l}\text { 24. Estrutura organizacional da } \\
\text { unidade }\end{array}$ & $\begin{array}{l}\text { Valorizando somente o que a liderança determina; } \\
\text { Valorizando a iniciativa individual; } \\
\text { Valorizando o poder concentrado na liderança; } \\
\text { Valorizando a responsabilidade compartilhada. }\end{array}$ & $\begin{array}{l}02 \\
09 \\
05 \\
10\end{array}$ & $\begin{array}{l}10 \\
03 \\
07 \\
02\end{array}$ \\
\hline 25. Comunicação & $\begin{array}{l}\text { Acerca do que é esperado do desempenho das } \\
\text { pessoas; } \\
\text { Dos acontecimentos críticos que marcam a história } \\
\text { da unidade; } \\
\text { Ocupação da unidade em saber como está sendo } \\
\text { percebido o seu processo de comunicação formal e } \\
\text { informal. }\end{array}$ & $\begin{array}{l}08 \\
12 \\
10\end{array}$ & $\begin{array}{l}04 \\
- \\
02\end{array}$ \\
\hline 26. Missão organizacional & $\begin{array}{l}\text { Ocupação da unidade em saber como está sendo } \\
\text { compreendida sua missão. }\end{array}$ & 10 & 02 \\
\hline 27. Valores & $\begin{array}{l}\text { Demonstração dos valores pelos quais se rege a } \\
\text { unidade; } \\
\text { Comunicação e/ou constatação, pelos empregados, } \\
\text { da coerência entre os valores e o sistema de gestão } \\
\text { da unidade. }\end{array}$ & $\begin{array}{l}11 \\
11\end{array}$ & 01 \\
\hline 28. Políticas & $\begin{array}{l}\text { Criação das condições de adaptação de políticas } \\
\text { integradas de recursos humanos à realidade da } \\
\text { organização e ao seu contexto de atuação nessa } \\
\text { unidade remota. }\end{array}$ & 10 & 02 \\
\hline
\end{tabular}

As unidades de codificação 1 a 8 dizem respeito às palavras-tema contidas nos aspectos do comportamento organizacional. A contagem de presenças totalitárias na unidade de codifícação 1 (palavra-chave 2), seguida de presenças expressivas nas unidades de codificação 1 (palavra-chave 1), 2, 3 (frase-chave2) 4, 7 e 8 e significativas nas unidades 3 (palavra-chave 1) e 6, mostra uma visão favorável dos entrevistados em relação aos aspectos ligados ao comportamento organizacional.

As presenças e ausências eqüitativas, contidas na palavra-tema da unidade 5, denotam a necessidade de condução de um diálogo investigativo das razões. Do mesmo modo, as ausências contidas na unidade de codificação 6, não podem ser consideradas desprezíveis. 
As unidades de codificação 9 a 16 estão voltadas para as palavras-tema contidas nos aspectos do comprometimento organizacional. A contagem de presenças é totalitária nas unidades de codificação 14 e 16 (frase-chave 2) e expressiva nas unidades de codificação 9, 10, 11, 13 e 16 (frase-chave 1), o que denota a favorabilidade, na percepção dos entrevistados, com relação a esses aspectos voltados para o comprometimento organizacional. As unidades de codificação 12 (em ambas as frases-chave, mas, principalmente na 2) e 15 mostram que as ausências são significativas e necessitam de investigação das razões que estão nelas embutidas.

As unidades de codificação 17 a 23 referem-se às palavras-tema contidas nos aspectos de gestão estratégica de pessoas. As presenças são totalizadoras nas unidades de codificação 17 (frase-chave 2) e 21; quase totalizadoras nas 18, 19 e 23 (frase-chave 2). As ausências observadas nas unidades de codificação 17 (frase-chave 1), 20, 22 e, principalmente, 23 (frase-chave 1) denotam necessidade de investigação para a compreensão das razões.

As unidades de codificação 24 a 28 estão no bojo das palavras-tema contidas nos aspectos da cultura organizacional. Verifique-se, nesse quadro, a ausência encontrada na unidade de codificação 24 - estrutura organizacional da unidade, com a frase-chave "valorizando somente o que a liderança determina" mostrando o aspecto positivo da falta de centralização do valor nas determinações oriundas somente das lideranças, o que é reforçado pela presença significativa da frase-chave "valorizando a responsabilidade compartilhada". A incidência de ausências na frase-chave "valorizando o poder concentrado na liderança" volta a chamar a atenção para a necessidade de investigação pelos gestores, na medida em que apresenta inconsistência com relação ao que foi dito acerca do compartilhamento. Ainda nessa mesma unidade de codificação, encontram-se presença substancial e ausência não desprezível na frase-chave "valorizando a iniciativa individual". Explore-se a ambivalência na possibilidade de representação de uma estrutura descentralizada.

As unidades de codificação 25 (frases-chave 2 e 3), 26, 27 (ambas as frases-chave) e 28, apresentam presenças expressivas, podendo denotar percepções favoráveis, na visão dos entrevistados, no que tange aos aspectos concernentes à cultura organizacional dessa unidade remota. $\mathrm{Na}$ unidade de codificação 25 , a frase-chave 1 pode indicar necessidade de investigação das prováveis causas das ausências nela contidas, uma vez que trata-se de comunicação de expectativas. 
O quadro $\mathrm{n}^{\circ}$. 19 apresenta o resultado da análise de conteúdo aplicadado ao escopo da pesquisa nessa unidade remota e contribui para aprofundar a compreensão do que foi mostrado no quadro $\mathrm{n}^{\mathrm{o}} .18$.

\begin{tabular}{|c|c|c|}
\hline \multicolumn{3}{|c|}{$\begin{array}{c}\text { QUADRO No } \text { Q }^{\circ} 19 \\
\text { RESULTADO DA ANÁLISE DE CONTEÚDO APLICADO AO ESCOPO DA PESQUISA } \\
\text { UNIDADE MONTE DOURADO }\end{array}$} \\
\hline $\begin{array}{l}\text { Categorias de } \\
\text { Análise }\end{array}$ & Temas Significativos & Unidade de Codificação \\
\hline $\begin{array}{l}\text { Comportamento } \\
\text { Organizacional }\end{array}$ & $\begin{array}{l}\text { Percepção da contri- } \\
\text { buição dos indivíduos, } \\
\text { dos grupos e da } \\
\text { estrutura. }\end{array}$ & $\begin{array}{l}\text { "Os funcionários são tolerantes às mudanças e as chefias tentam } \\
\text { repassar a importância dessas mudanças, de modo que não são criadas } \\
\text { resistências." } \\
\text { "As pessoas contribuem por achar que as mudanças sempre implicam } \\
\text { em melhorias. Elas se comprometem com isso." } \\
\text { "A empresa se ocupa muito em criar a infra-estrutura voltada para } \\
\text { educação, saúde, lazer e habitação para facilitar que as pessoas } \\
\text { permaneçam na unidade." } \\
\text { "O convívio dentro e fora do trabalho às vezes desgasta a relação das } \\
\text { pessoas." }\end{array}$ \\
\hline $\begin{array}{c}\text { Comprometimento } \\
\text { Organizacional }\end{array}$ & $\begin{array}{l}\text { Percepção do orgulho e } \\
\text { do empenho exercido } \\
\text { pelos indivíduos em } \\
\text { favor dessa unidade. }\end{array}$ & $\begin{array}{l}\text { "Muitas pessoas sentem orgulho porque tiveram oportunidades. } \\
\text { Outras não, daí fica muito relativo e a percepção, no geral, é que o } \\
\text { orgulho é razoável." } \\
\text { "A maioria das pessoas na unidade procura desenvolver suas } \\
\text { atividades profissionais de forma correta, não obstante estejam ou não, } \\
\text { orgulhosas." } \\
\text { "As pessoas têm muito orgulho, apesar das dificuldades." } \\
\text { "O empenho é visível em recordes de produção e segurança." } \\
\text { "O empenho reforça os resultados, que por sua vez alimenta o orgulho } \\
\text { de vestir a camisa." } \\
\text { "Algumas pessoas expressam o seu orgulho enfaticamente. As que } \\
\text { vêm automotivadas engajam-se, estudam a distância e progridem." }\end{array}$ \\
\hline $\begin{array}{c}\text { Gestão Estratégica } \\
\text { de Pessoas }\end{array}$ & $\begin{array}{l}\text { Percepção da adoção de } \\
\text { novas práticas de } \\
\text { gestão, de modo a } \\
\text { facilitar as ações de } \\
\text { desenvolvimento e } \\
\text { resolução de conflitos } \\
\text { nessa unidade remota. }\end{array}$ & $\begin{array}{l}\text { "A empresa tem se empenhado com novos modelos de gestão, de } \\
\text { modo a criar desenvolvimento das pessoas e facilitar a resolução de } \\
\text { conflitos." } \\
\text { "O relacionamento na unidade como um todo favorece à abertura para } \\
\text { a minimização dos conflitos e diminuição de distâncias hierárquicas. } \\
\text { As pessoas têm acesso ao gerente e aos outros níveis facilmente aqui } \\
\text { dentro." } \\
\text { "Quando as pessoas são ouvidas pela estrutura hierárquica os } \\
\text { resultados elas dão retornos expressivos para a unidade e para a } \\
\text { organização." } \\
\text { "Essa estrutura só precisa lembrar que o trabalho é para as pessoas, } \\
\text { com as pessoas e por intermédio delas. Se os gestores sabem como } \\
\text { fazer isso o resultado é fantástico." } \\
\text { "As pessoas gostam de ser estimuladas e dão tudo de si quando assim } \\
\text { se sentem." } \\
\text { "Nos últimos dez anos o apoio ao estudo tem gerado muito mais }\end{array}$ \\
\hline
\end{tabular}




\begin{tabular}{|c|c|c|}
\hline & & interesse pelo desenvolvimento pessoal e profissional." \\
\hline $\begin{array}{l}\text { Categorias de } \\
\text { Análise }\end{array}$ & Temas Significativos & Unidade de Codificação \\
\hline $\begin{array}{c}\text { Cultura } \\
\text { Organizacional }\end{array}$ & $\begin{array}{l}\text { Percepção do co- } \\
\text { nhecimento que os } \\
\text { indivíduos têm acerca } \\
\text { da visão, filosofia de } \\
\text { atuação, missão e } \\
\text { valores nessa unidade } \\
\text { remota. }\end{array}$ & $\begin{array}{l}\text { "Atualmente a unidade passa por um momento de grande } \\
\text { conscientização. Expõem-se as filosofias, as normas, os } \\
\text { procedimentos e as políticas para que as pessoas os sigam. Elas estão } \\
\text { assimilando que a empresa está repassando de informações a partir do } \\
\text { momento de entrevistas para a seleção." } \\
\text { "Visão, filosofia de atuação, missão e valores da unidade são mais } \\
\text { profundamente assimilados quando os gestores fazem o seu trabalho } \\
\text { de gestão com as pessoas." } \\
\text { "As pessoas precisam compreender o porquê de visão, filosofia de } \\
\text { atuação, missão e valores da unidade para incorporarem de modo mais } \\
\text { adequado." } \\
\text { "A cultura, antes fortemente competitiva, migrou para a cooperação } \\
\text { entre todos os níveis e áreas." }\end{array}$ \\
\hline
\end{tabular}

Os entrevistados afirmam que as mudanças para a vida, em unidades remotas, geram desconforto e uma série de comportamentos diferenciados. Os modelos de gestão são olhados pelos representantes dessa unidade sob a ótica da adaptação das pessoas. As estruturas de Munguba, centro da unidade e de Monte Dourado, vila residencial, podem facilitar ou dificultar, pela mesma razão: a aproximação inevitável das pessoas em seu cotidiano.

A privação de alguns aspectos da vida, no isolamento do remoto confinado é considerada grande. Muitas vezes a unidade investe nessas pessoas e elas não ficam muito tempo. Por outro lado, a maioria das que ficam tem vínculos familiares fortes, pois escolhe conscientemente fugir dos grandes centros e criar os filhos em condições mais saudáveis. As que escolhem permanecer geram contribuições significativas, em função de suas habilidades (quer individuais, quer articuladas em grupos) serem utilizadas em prol dessa unidade.

A política de gestão abrange visão, filosofia, missão e valores, de tal modo, que leva ao indivíduo a importância dos seus objetivos. Desde o treinamento introdutório o SIM Sistema Integrado de Melhoria, fala de todas as coisas que o empregado precisa conhecer. Há o reconhecimento de um grande esforço na promoção de ações de desenvolvimento. Aos poucos, as pessoas vão internalizando e consolidando a essência dessa política.

De acordo com os dados da pesquisa, as últimas práticas adotadas de gestão de pessoas, dentre elas os treinamentos intensificados, têm facilitado o desenvolvimento e a resolução de conflitos, unindo as áreas, sintonizando os esforços para os resultados. 
Há um cuidado especial em adotar práticas voltadas para o desenvolvimento das pessoas e para a resolução adequada dos conflitos na unidade. Os gestores estão sendo preparados para atuar melhor nessa direção. No entanto, o tempo proposto por esses gestores para permanência nessa unidade é percebido como curto para se desenvolver um trabalho consistente. $\mathrm{O}$ valor de residir em Monte Dourado é percebido como não internalizado por todos e, a distância é aumentada para a conquista do ideal de gestão. É enfatizado que os gestores que sentem prazer em morar no local da unidade interagem com as pessoas em todas as circunstâncias. Os que têm dificuldade de adaptação das famílias necessitam voltar para os seus locais de origem, o que representa muitas perdas. Essa circunstância já está sendo revista por alguns desses gestores.

As entrevistas atestam que as pessoas sentem orgulho por trabalharem na unidade e a vêem como um centro de excelência no meio da floresta. A empresa e os profissionais que nela trabalham são reconhecidos pelo mercado. Internamente, o orgulho é expresso nos diálogos de trabalho, nas conversas informais, nas ações de melhoria para os resultados.

O empenho é confirmado pelo alto índice de obtenção desses resultados, notadamente os de produção, segurança e meio-ambiente. As pessoas não ficam só atreladas aos treinamentos. Elas se empenham fortemente para que tudo corra bem. Esse empenho é percebido pelo esforço permanente de todos para atingir os objetivos.

A estrutura é criada em função da preservação do bem-estar das pessoas, de modo a favorecer a permanência delas na unidade, mas não necessariamente assegura que elas permaneçam. Somente a adaptação dessas pessoas e das suas famílias é que pode assegurar o tempo maior dessa permanência.

Com relação à saúde, há indicação de problema, uma vez que o hospital é tido como de estrutura precária para as necessidades e, em caso de problemas graves de saúde ou acidentes, o custo de atendimento para deslocamentos em UTI's aéreas é considerado muito elevado. Há um trabalho em andamento, no sentido de criar a infra-estrutura adequada ao atendimento das pessoas no próprio local.

Os entrevistados salientam que os resultados podem ser vistos como favoráveis, oriundos de alto grau de comprometimento das pessoas e os sistemas criados podem se ditos como 
estimulantes. Os dados da pesquisa mostram que os sistemas estruturais e estruturantes da unidade facilitam as ações dos conflitos das pessoas no que tange às questões familiares e de trabalho. Entretanto, há a percepção entre os entrevistados, de que as práticas de gestão precisam evoluir do plano operacional para o estratégico, com a compreensão que a retenção de talentos é função de: salário digno, competência estimulada para ser incrementada e vontade de crescer mapeada e estimulada.

Enfatize-se que os dados da pesquisa, nessa unidade, mostram chefias e colegas de todas as áreas e/ou da mesma área estimulando: feedbacks, debates, cooperação, valorização do trabalho, reconhecimento pela capacidade de desenvolvimento, confiabilidade e colaboração. A unidade é reconhecida como um bom lugar para se trabalhar e constitui-se em sonho de muitas pessoas da região, a ocupação de uma posição dentro dela. Nesse ponto dá-se o cruzamento dos aspectos ligados a comportamento, comprometimento, gestão de pessoas e cultura organizacional, detalhados no quadro $\mathrm{n}^{\mathrm{o}} 18$.

\section{2. 3 Unidade: Barcarena - Finalização e Embarque}

Antiga aldeia dos índios Aruãs, Barcarena passou a chamar-se assim em 1938 e, em 1943 foi elevada à categoria de município. O município de Barcarena pertence à mesorregião Metropolitana de Belém e à microrregião de Belém.

É um importante pólo industrial, onde é feita a industrialização, beneficiamento e exportação de caulim, alumina, alumínio e cabos para transmissão de energia elétrica. Inicialmente as residências foram construídas na Vila dos Cabanos, a qual teve sua infra-estrutura criada e administrada pela ALBRAS. A ALUNORTE foi responsável pela ampliação e pela adaptação à realidade da época. Essa Vila foi entregue posteriormente para a Prefeitura administrar.

A unidade Barcarena, considerada semi-remota, não isolada e não confinada, fica localizada próximo à vila residencial dos Cabanos e dista aproximadamente 40 quilômetros de Belém. Por cuidar da finalização e do embarque das unidades de Ipixuna e Monte Dourado ela também fez parte da pesquisa. Seu acesso é possibilitado por balsa ou estrada asfaltada. A exportação do caulim é feita por essa unidade, no Porto de Conde. 
O quadro $n^{\circ} .20$ apresenta o resultado da análise de conteúdo das oito entrevistas realizadas nessa unidade.

\begin{tabular}{|c|c|c|c|}
\hline \multicolumn{4}{|c|}{$\begin{array}{l}\text { QUADRO No } \mathbf{N}^{\circ} 2 \\
\text { RESULTADO DA ANÁLISE DE CONTEÚDO UNIDADE BARCARENA }\end{array}$} \\
\hline \multirow{2}{*}{$\begin{array}{l}\text { Unidade de Codificação } \\
\text { Palavras-tema }\end{array}$} & \multirow{2}{*}{ Palavras-chave ou Frases-chave } & \multicolumn{2}{|c|}{ Contagem } \\
\hline & & Presença & Ausência \\
\hline 1. Feedback & $\begin{array}{l}\text { Estímulo; } \\
\text { Evidência. }\end{array}$ & $\begin{array}{l}07 \\
08\end{array}$ & $\begin{array}{c}01 \\
-\end{array}$ \\
\hline 2. Interações & Integrantes dos diversos escalões. & 08 & - \\
\hline 3. Abertura & $\begin{array}{l}\text { Encorajamento para debates; } \\
\text { Ocorrência de debates. }\end{array}$ & $\begin{array}{l}04 \\
08\end{array}$ & $\begin{array}{c}04 \\
-\end{array}$ \\
\hline 4. Comunicações interpessoais & Ocorrência entre as áreas. & 07 & 01 \\
\hline 5. Emoções & Expressão. & 05 & 03 \\
\hline 6. Pensar, sentir e agir & Evidência de interface. & 03 & 05 \\
\hline 7. Tomada de decisão & Ocorrência de em grupo. & 05 & 03 \\
\hline 8. Comportamento intergrupal & Favorecendo o trabalho em equipe. & 06 & 02 \\
\hline 9. Participação & Estímulo à atitude de participação do empregado. & 06 & 02 \\
\hline 10. Envolvimento & $\begin{array}{l}\text { Estímulo à atitude de envolvimento do empregado } \\
\text { com os objetivos organizacionais. }\end{array}$ & 05 & 03 \\
\hline 11. Comprometimento & $\begin{array}{l}\text { Estímulo à atitude de comprometimento } \\
\text { (identificação) do empregado com os objetivos } \\
\text { organizacionais. }\end{array}$ & 05 & 03 \\
\hline 12. Expectativas & $\begin{array}{l}\text { Possibilidade de o empregado comunicar } \\
\text { expectativas em relação à unidade. } \\
\text { Ocorrência de comunicação das expectativas da } \\
\text { unidade em relação ao empregado. }\end{array}$ & 06 & 02 \\
\hline 13. Responsabilidades & $\begin{array}{l}\text { Estímulo para o empregado assumir responsabili- } \\
\text { dades sobre suas ações. }\end{array}$ & 07 & 01 \\
\hline 14. Engajamento & $\begin{array}{l}\text { Estímulo para o engajamento das pessoas aos } \\
\text { objetivos e metas organizacionais. }\end{array}$ & 08 & - \\
\hline 15. Características da unidade & $\begin{array}{l}\text { Estimulando as pessoas a despenderem esforços } \\
\text { para nela permanecerem. }\end{array}$ & 04 & 04 \\
\hline 16. Cooperação & $\begin{array}{l}\text { Estímulo à atitude de cooperação; } \\
\text { Evidência da cooperação. }\end{array}$ & $\begin{array}{l}06 \\
08\end{array}$ & $\begin{array}{c}02 \\
-\end{array}$ \\
\hline 17. Valorização & $\begin{array}{l}\text { Evidência da valorização de opiniões e desco- } \\
\text { bertas em relação à maneira de se obter resultados; } \\
\text { Evidência da valorização do trabalho. }\end{array}$ & 07 & $\begin{array}{l}01 \\
-\end{array}$ \\
\hline 18. Aprendizagem/reaprendizagem & $\begin{array}{l}\text { Reconhecimento da necessidade de aprendizagem / } \\
\text { reaprendizagem em relação ao trabalho. }\end{array}$ & 06 & 02 \\
\hline 19. Desenvolvimento & $\begin{array}{l}\text { Demonstração do estímulo ao desenvolvimento } \\
\text { pessoal e profissional na própria organização. }\end{array}$ & 06 & 02 \\
\hline 20. Incentivos & $\begin{array}{l}\text { Disponibilização de incentivos vinculados a } \\
\text { resultados obtidos pela equipe. }\end{array}$ & 04 & 04 \\
\hline 21. Reconhecimento & $\begin{array}{l}\text { As pessoas são capazes de: desenvolvimento, } \\
\text { confiança e colaboração. }\end{array}$ & 08 & - \\
\hline $\begin{array}{l}\text { 22. Características organizacionais } \\
\text { da unidade. }\end{array}$ & $\begin{array}{l}\text { Atrair e reter pessoas de alto potencial e } \\
\text { qualificação para o trabalho. }\end{array}$ & 02 & 06 \\
\hline $\begin{array}{l}\text { 23. Criação de condições de trabalho } \\
\text { na unidade. }\end{array}$ & $\begin{array}{l}\text { Favoráveis à manutenção da motivação individual } \\
\text { para o trabalho; } \\
\text { Favoráveis à mobilização dos grupos em torno das } \\
\text { metas organizacionais. }\end{array}$ & $\begin{array}{l}03 \\
07\end{array}$ & 05 \\
\hline $\begin{array}{l}\text { 24. Estrutura organizacional da } \\
\text { unidade. }\end{array}$ & $\begin{array}{l}\text { Valorizando somente o que a liderança determina; } \\
\text { Valorizando a iniciativa individual; } \\
\text { Valorizando o poder concentrado na liderança; } \\
\text { Valorizando a responsabilidade compartilhada. }\end{array}$ & $\begin{array}{c}01 \\
05 \\
- \\
07\end{array}$ & $\begin{array}{l}07 \\
03 \\
08 \\
01\end{array}$ \\
\hline 25. Comunicação. & $\begin{array}{l}\text { Acerca do que é esperado do desempenho das } \\
\text { pessoas; } \\
\text { Dos acontecimentos críticos que marcam a história }\end{array}$ & 05 & 03 \\
\hline
\end{tabular}




\begin{tabular}{|l|l|c|c|}
\hline & $\begin{array}{l}\text { da unidade; } \\
\text { Ocupação da unidade em saber como está sendo } \\
\text { percebido o seu processo de comunicação formal e } \\
\text { informal. }\end{array}$ & 07 & 01 \\
\hline $\begin{array}{c}\text { Unidade de Codificação } \\
\text { Palavras-tema }\end{array}$ & \multicolumn{1}{|c|}{ Palavras-chave ou Frases-chave } & Contagem \\
\cline { 2 - 4 } & $\begin{array}{l}\text { Ocupação da unidade em saber como está sendo } \\
\text { compreendida sua missão. }\end{array}$ & 06 & 02 \\
\hline 26. Missão organizacional. & $\begin{array}{l}\text { Demonstração dos valores pelos quais se rege a } \\
\text { unidade; } \\
\text { Comunicação e/ou constatação, pelos empregados, } \\
\text { da coerência entre os valores e o sistema de gestão } \\
\text { da unidade. }\end{array}$ & 07 & 01 \\
\hline 28. Políticas. & $\begin{array}{l}\text { Crição das condições de adaptação de políticas } \\
\text { integradas de recursos humanos à realidade da } \\
\text { organização e ao seu contexto de atuação nessa } \\
\text { unidade remota. }\end{array}$ & 08 & 07 \\
\hline
\end{tabular}

As unidades de codificação 1 a 8 dizem respeito às palavras-tema contidas nos aspectos do comportamento organizacional. A contagem de presenças totalitárias nas unidades de codificação 1 (palavra-chave 2), 2 e 3 (frase-chave 2), seguida de presenças expressivas nas unidades 1 (palavra-chave1), 4 e 8, mostra uma visão favorável dos entrevistados em relação aos aspectos ligados ao comportamento organizacional. As ausências contidas nas palavras-tema 3, 5, 6 e 7, não são desprezíveis e podem ser conduzidas a um diálogo investigativo das razões.

As unidades de codificação 9 a 16 estão voltadas para as palavras-tema contidas nos aspectos do comprometimento organizacional. A contagem de presenças é totalitária nas unidades de codificação 14 e 16 (frase-chave 2); expressiva nas unidades de codificação 9,12, 13 e 16 (frase-chave 1) e significativas nas unidades de codificação 10 e 11, o que denota favorabilidade, na percepção dos entrevistados, com relação a esses aspectos voltados para o comprometimento. As unidades de codificação 12 (frase-chave2) e 15 (principalmente), mostram que as ausências são significativas e necessitam de investigação das razões que estão nelas embutidas.

As unidades de codificação 17 a 23 referem-se às palavras-tema contidas nos aspectos de gestão estratégica de pessoas. As presenças são totalizadoras nas unidades de codificação 17 (frase-chave 2) e 21; quase totalizadoras nas 17 (frase-chave 1), 18, 19 e 23 (frase-chave 2). As ausências observadas nas unidades de codificação 20, 22 (principalmente) e 23 (frase-chave 1), denotam necessidade de investigação para a compreensão das razões. 
As unidades de codificação 24 a 28 estão no bojo das palavras-tema contidas nos aspectos da cultura organizacional. Observe-se, nesse quadro, a ausência encontrada na unidade de codificação 24 - estrutura organizacional da unidade, com as frases-chave "valorizando somente o que a liderança determina" e "valorizando o poder concentrado na liderança", mostrando o aspecto positivo da falta de centralização do valor nas determinações oriundas somente das lideranças, o que vem a ser reforçado pela presença quase totalitária da frasechave "valorizando a responsabilidade compartilhada". Ainda nessa mesma unidade de codificação, encontram-se presença substancial e ausência não desprezível da frase-chave "valorizando a iniciativa individual".

Todos esses resultados podem denotar a percepção de uma estrutura flexível e aberta. As unidades de codificação 25 (frases-chave 2 e 3), 26, 27 e 28 (principalmente), apresentam presenças expressivas, podendo denotar percepções favoráveis, na visão dos entrevistados, no que tange aos aspectos concernentes à cultura organizacional dessa unidade semi-remota.

O quadro $\mathrm{n}^{\mathrm{o}}$. 21 apresenta o resultado da análise de conteúdo aplicadado ao escopo da pesquisa nessa unidade e contribui para aprofundar a compreensão do que foi mostrado no quadro $n^{\circ} .20$.

\begin{tabular}{|c|c|c|}
\hline \multicolumn{3}{|c|}{$\begin{array}{l}\text { QUADRO No. } 21 \\
\text { RESULTADO DA ANÁLISE DE CONTEÚDO APLICADO AO ESCOPO DA PESQUISA } \\
\text { UNIDADE BARCARENA }\end{array}$} \\
\hline $\begin{array}{l}\text { Categorias de } \\
\text { Análise }\end{array}$ & Temas Significativos & Unidade de Codificação \\
\hline $\begin{array}{c}\text { Comportamento } \\
\text { Organizacional }\end{array}$ & $\begin{array}{l}\text { Percepção da contri- } \\
\text { buição dos indivíduos, } \\
\text { dos grupos e da } \\
\text { estrutura. }\end{array}$ & $\begin{array}{l}\text { "Há muitos desafios. A estrutura contribui ao oferecê-los e as } \\
\text { pessoas, ao enfrentá-los." } \\
\text { "A dedicação das pessoas, principalmente na área operacional, é uma } \\
\text { peça-chave no processo de contribuição." } \\
\text { "A estrutura é enxuta e facilita as operacionalizações, pois reduz as } \\
\text { distâncias para a tomada de decisão." } \\
\text { "A estrutura remota, em geral, cria condição para que as contribuições } \\
\text { fluam. A hierarquia acontece como um processo natural." } \\
\text { "O vínculo criado na estrutura remota é agregador. O fato de as } \\
\text { pessoas se conhecerem fora da unidade facilita o processo de } \\
\text { trabalho." } \\
\text { "O empenho das pessoas para ajudar e contribuir nas soluções dos } \\
\text { problemas da unidade é freqüente." } \\
\text { "A estrutura ajuda no sentido de apoiar as pessoas. Por ser uma } \\
\text { unidade remota a convivência permanente também facilita." }\end{array}$ \\
\hline
\end{tabular}




\begin{tabular}{|c|c|c|}
\hline & & $\begin{array}{l}\text { "Individualmente cada um dá o que tem de si. Nos grupos, as chefias } \\
\text { ainda podem ajudar mais as interações e as comunicações. A estrutura } \\
\text { ajuda a aumentar a dedicação." }\end{array}$ \\
\hline $\begin{array}{l}\text { Categorias de } \\
\text { Análise }\end{array}$ & Temas Significativos & Unidade de Codificação \\
\hline $\begin{array}{c}\text { Comprometimento } \\
\text { Organizacional }\end{array}$ & $\begin{array}{l}\text { Percepção do orgulho e } \\
\text { do empenho exercido } \\
\text { pelos indivíduos em } \\
\text { favor dessa unidade } \\
\text { semi-remota. }\end{array}$ & $\begin{array}{l}\text { "As pessoas demonstram o orgulho em trabalhar na unidade e, quanto } \\
\text { mais se sentem valorizada mais dão de si mesmas." } \\
\text { "As pessoas empenham-se constantemente em suas atribuições e } \\
\text { trabalham na construção da obtenção dos resultados da unidade com } \\
\text { muita dedicação." } \\
\text { "O comprometimento atesta o orgulho das pessoas, oriundo do } \\
\text { trabalho com empenho, por elas realizado. As pessoas são } \\
\text { verdadeiramente empenhadas com as suas atividades e demonstram o } \\
\text { seu orgulho com os resultados relevantes para a unidade e para a } \\
\text { organização." } \\
\text { "A harmonia do grupo está muito relacionada às suas interações } \\
\text { dentro da unidade e na comunidade. Isso incrementa o empenho e o } \\
\text { resultado é de alta performance." } \\
\text { "A valorização é um ponto-chave para o gestor. É importante passar o } \\
\text { desafio e dizer para as pessoas o quanto elas são valiosas. O orgulho é } \\
\text { oriundo da valorização que elas sentem." } \\
\text { “As pessoas são muito comprometidas. Quando as metas são lançadas, } \\
\text { elas dão 'sangue' para atender. Elas demonstram seu orgulho junto } \\
\text { com a alegria e o empenho." }\end{array}$ \\
\hline $\begin{array}{c}\text { Gestão Estratégica } \\
\text { de Pessoas }\end{array}$ & $\begin{array}{l}\text { Percepção da adoção de } \\
\text { novas práticas de } \\
\text { gestão, de modo a } \\
\text { facilitar as ações de } \\
\text { desenvolvimento e e } \\
\text { resolução de conflitos } \\
\text { nessa unidade. }\end{array}$ & $\begin{array}{l}\text { "Os conflitos existem, até mesmo entre os pares de liderança. As } \\
\text { práticas mediadoras de gestão facilitam." } \\
\text { "Há liberdade de adoção de práticas de facilitação em todas as } \\
\text { circunstâncias na unidade. O processo de gerar feedback pode ser mais } \\
\text { aprimorado. Falta ainda um pouco mais de humanização." } \\
\text { "A adoção de novas práticas de gestão tem se mostrado favorável, } \\
\text { tanto para o desenvolvimento das pessoas quanto para a resolução de } \\
\text { conflitos quando eles surgem na unidade." } \\
\text { "Para algumas pessoas a organização disponibiliza ações de } \\
\text { desenvolvimento (principalmente para as que exercem funções de } \\
\text { gestão). Para a resolução de conflito fica a cargo das áreas e dos } \\
\text { gestores. O mesmo procedimento ocorre com relação ao feedback de } \\
\text { desempenho." } \\
\text { "A profissionalização é estimulada, o estudo é incentivado e as } \\
\text { pessoas estão aderindo." }\end{array}$ \\
\hline $\begin{array}{c}\text { Cultura } \\
\text { Organizacional }\end{array}$ & $\begin{array}{l}\text { Percepção do co- } \\
\text { nhecimento que os } \\
\text { indivíduos têm acerca } \\
\text { da visão, filosofia de } \\
\text { atuação, missão e } \\
\text { valores nessa unidade } \\
\text { semi-remota. }\end{array}$ & $\begin{array}{l}\text { "A comunicação é boa. Daí, para as pessoas conhecerem a visão, a } \\
\text { filosofia, a missão e os valores fica muito mais fácil, pois tudo fica } \\
\text { estampado." } \\
\text { "A empresa tem políticas que precisam ser repassadas para a unidade. } \\
\text { O valor segurança é prioritário e o trabalho com ele é incessante." } \\
\text { "Missão, filosofia, visão e valores constituem a cultura. Gradualmente } \\
\text { isso é passado para todos e é percebido o engrandecimento que essa } \\
\text { ação traz." } \\
\text { "Com todas as mudanças que vêm ocorrendo a unidade encontra-se } \\
\text { em processo de instauração de uma cultura única (CADAM / PPSA). } \\
\text { O processo de tornar conhecida essa cultura vem sendo trabalhado no } \\
\text { cotidiano das atividades. Há muitos desafios pela frente." }\end{array}$ \\
\hline \multicolumn{3}{|c|}{ onte: a autora, com base nos dados da pesquisa. } \\
\hline
\end{tabular}


Os entrevistados enfatizam que os resultados da unidade são obtidos a partir da contribuição de todos. A estrutura vem contribuindo gradativamente com os resultados operacionais e, não obstante todas as mudanças oriundas de re-estruturações, as pessoas sentem tal contribuição.

A questão como a gestão de pessoas facilita ou dificulta a obtenção do comprometimento é respondida nessa unidade a partir dos parágrafos subseqüentes, nos quais são percebidas as práticas que podem facilitar a retenção dos talentos.

Alguns gestores atendem às três unidades e essa é uma especificidade dessa organização. Em algumas dessas unidades a periodicidade com que estão com a equipe é mensal. Esses gestores afirmam que se sentem tentados a desafiar constantemente os seus gerenciados para que eles possam decidir com base em suas convicções.

Entretanto, há o registro de que esses gerenciados sentem-se inseguros com essas ausências, não obstante seja mostrado o valor que eles têm. Ganha a unidade localizada mais próxima da residência dos gestores. Outros gestores moram na Vila dos Cabanos e reconhecem o valor que isso tem para as equipes em Barcarena.

As características dos gestores podem ser traduzidas nessa unidade em: flexibilidade, saber ouvir a equipe, facilitação na execução das tarefas com o compartilhamento da equipe, estímulo à co-responsabilidade, aprimoramento da prática de valorização das pessoas.

A área de recursos humanos na unidade era muito incipiente. Pouco a pouco foram implantadas as práticas que mostram o foco no desenvolvimento das pessoas e da própria unidade, nas quais as resoluções de conflitos são mediadas pelos gestores e acompanhadas, quando necessário, por profissionais de RH.

Os gestores são ajudados pelo RH e pelos comitês multidisciplinares. A falta de barreira entre eles é também percebida como de grande ajuda na prática cotidiana, com abertura para ouvir e trocar. Ações como seminários fora, pessoas para fazer palestras dentro da unidade e treinamentos, facilitam o desenvolvimento. Isso tudo leva à transparência das ações, de acordo com os entrevistados. 
Os dados da pesquisa mostram que as pessoas sentem orgulho em trabalhar nessa unidade, pois ela valoriza as qualificações que os empregados têm ou podem ter. Nesses dados, tem-se a seguinte distinção: as pessoas da área operacional mostram o seu orgulho na unidade, pelo fato de serem reconhecidas e prioritariamente contratadas na própria região; o orgulho é intensamente percebido nos veteranos; o sentimento de orgulho é desenvolvido e expresso, toda vez que um empregado terceirizado é contratado na unidade; dos cargos de analista para cima há um grau elevado de comprometimento, mas o orgulho não é tão expresso e essas pessoas são recrutadas em Belém e em outras capitais.

O empenho existe e é verbalizado pelos empregados. Esse empenho também está vinculado com o respeito pela empresa. O orgulho torna-se mais visível e é traduzido pelos resultados positivos em prol da unidade.

Não obstante a presença de outras empresas como ALBRAS e ALUNORTE, no mesmo pólo, podendo representar ameaça de absorção da mão-de-obra preparada, o empenho em realizar um trabalho de excelência nessa unidade é grande e as pessoas não a deixam.

Em Barcarena, os focos da empresa voltam-se para a capacitação profissional e o aperfeiçoamento na área da produção, desenvolvidos em parceria com o Serviço Nacional de Aprendizagem Rural (SENAR). Atividades agrícolas, de pesca, avicultura e apicultura são oferecidas com intuito de promover e estimular à geração de trabalho e renda. As práticas de gestão são gerais para as unidades de Barcarena, Ipixuna e Monte Dourado. Entretanto, há liberdade de ajustes em cada uma delas, quando e se necessário.

Ressalte-se que os dados da pesquisa, nessa unidade, mostram chefias e colegas de todas as áreas e/ou da mesma área estimulando: feedbacks, debates, cooperação, valorização do trabalho, reconhecimento pela capacidade de desenvolvimento, confiabilidade e colaboração. Nesse ponto dá-se o cruzamento dos aspectos ligados a comportamento, comprometimento, gestão de pessoas e cultura organizacional, detalhados no quadro $\mathrm{n}^{\circ} .20$.

Foram registradas diferenças e semelhanças entre as unidades desse caso. Elas encontram-se condensadas na ilustração $n^{\circ} 03$. 
ILUSTRAÇÃO №. 03

DIFERENÇAS E SEMELHANÇAS ENTRE UNIDADES CASO 4. 2. CADAM / PPSA

\begin{tabular}{|c|c|c|}
\hline $\begin{array}{l}\text { Ipixuna } \\
\text { Estrutura de alojamentos gerenciais, } \\
\text { administrativos e operacionais; } \\
\text { Regime de trabalho de } 15 \times 15 \text { dias para o } \\
\text { nível operacional; } \\
\text { Ausência de alguns gestores por um } \\
\text { período considerado longo. }\end{array}$ & $\begin{array}{l}\text { Monte Dourado } \\
\text { As moradias na vila, incluindo água e } \\
\text { energia, são subsidiadas pela unidade; } \\
\text { Ajuda para deslocamentos em férias, uma } \\
\text { vez por ano. }\end{array}$ & $\begin{array}{l}\text { Barcarena } \\
\text { As moradias em Vila dos Cabanos, ainda } \\
\text { são utilizadas por gestores da unidade; } \\
\text { O acesso é fácil para Belém e existem } \\
\text { pessoas morando lá; } \\
\text { Sustentabilidade buscada em parceria com } \\
\text { o Serviço Nacional de Aprendizagem Rural } \\
\text { - SENAR. }\end{array}$ \\
\hline \multicolumn{3}{|c|}{$\begin{array}{l}\text { Alguns gestores atendem às três unidades; } \\
\text { Sistema Integrado de Melhorias - SIM; } \\
\text { Educação é um foco comum; } \\
\text { responsabilidade social e proteção ambiental são internalizadas; } \\
\text { ho traduzido pelos resultados em prol das unidades; } \\
\text { lade para assimilação da cultura única CADAM / PPSA. }\end{array}$} \\
\hline
\end{tabular}

Fonte: a autora, com base nos dados da pesquisa.

Há sinergia entre as interfaces, o que facilita mais ainda o comprometimento organizacional na empresa. Muitos são os exemplos de pessoas empenhadas, engajadas e comprometidas, que cresceram nela, de acordo com os dados da pesquisa.

As semelhanças mostram os traços que unem as pessoas, em todas essas localidades e em torno do mesmo propósito: reter talentos nas duas unidades com estruturas organizacionais remotas e na semi-remota nessa empresa.

As diferenças denotam os aspectos ligados a comportamento, comprometimento, gestão de pessoas e cultura organizacional, todos eles em interação para a consecução desse propósito nesse caso 4.2 .

\section{3 Caso Grupo Orsa}

O Projeto Jarí ocupa 1.734.606 hectares distribuídos em terras nos Estados do Pará (55\%) e do Amapá (45\%), cortadas pelo rio Jari, que faz a divisa entre os dois Estados. Na região do Jari vivem hoje cerca de 100.000 habitantes, distribuídos pelas cidades de Monte Dourado (Pará), Laranjal do Jari (Amapá), Vitória do Jari (Amapá) e Almeirim (Pará). 
Em 1948, empresários portugueses e brasileiros criaram a Jari Indústria e Comércio e passaram a trabalhar também com a exportação de madeiras nobres e no comércio de mercadorias diversas, através de entrepostos às margens dos rios Jari, Paru, Caracuru, Cajari e Panacari com as mesmas atividades extrativistas.

Em maio de 1979, a fábrica de celulose iniciava suas operações.

Em 2000, o Grupo ORSA apresentou a melhor proposta para a re-estruturação do Projeto Jari e em 2001 foi instalada uma unidade da Fundação Orsa em Monte Dourado. Com cerca de 12.000 habitantes, Monte Dourado dista $95 \mathrm{~km}$ ao Sul da Linha do Equador. É distrito do município de Almeirim - Pará, situado às margens do rio Amazonas.

\section{3. 1 Unidade: Jari Celulose}

A sede da Jari Celulose S.A. está situada no distrito de Monte Dourado, às margens do rio Jari, no Estado do Pará.

A fábrica de celulose está localizada no distrito industrial de Munguba, a aproximadamente $18 \mathrm{~km}$ de Monte Dourado, também às margens do rio Jari, ocupando uma localização considerada estratégica: é a fábrica brasileira de celulose situada mais próxima dos principais mercados consumidores - Europa, América do Norte e Ásia; apresenta curta distância entre a floresta, a fábrica e o porto fluvial privativo, com capacidade para receber navios de até 200 metros de comprimento; as condições naturais de clima e solo e a utilização da melhor tecnologia silvicultural disponível, permitem o cultivo de florestas de alta produtividade, onde cresce o eucalipto de ciclo curto de corte; esse perfil industrial possibilita a obtenção de excelente celulose, produzida de acordo com especificações do cliente.

É uma unidade remota, isolada e confinada, na qual toda a infra-estrutura para a produção de celulose, foi implada na região. Seu acesso é possível pelo Aeroporto próprio ou pelo rio Jari.

O quadro $n^{\circ} .22$ apresenta o resultado da análise de conteúdo das seis entrevistas realizadas nessa unidade. 


\begin{tabular}{|c|c|c|c|}
\hline \multicolumn{4}{|c|}{$\begin{array}{l}\text { QUADRO Nº } 22 \\
\text { RESULTADO DA ANÁLISE DE CONTEUUDO UNIDADE JARÍ CELULOSE }\end{array}$} \\
\hline \multirow{2}{*}{$\begin{array}{l}\text { Unidade de Codificação } \\
\text { Palavras-tema }\end{array}$} & \multirow[t]{2}{*}{ Palavras-chave ou Frases-chave } & \multicolumn{2}{|c|}{ Contagem } \\
\hline & & Presença & Ausência \\
\hline 1. Feedback & $\begin{array}{l}\text { Estímulo; } \\
\text { Evidência. }\end{array}$ & $\begin{array}{l}04 \\
06\end{array}$ & $\begin{array}{c}02 \\
-\end{array}$ \\
\hline 2. Interações & Integrantes dos diversos escalões. & 05 & 01 \\
\hline 3. Abertura & $\begin{array}{l}\text { Encorajamento para debates; } \\
\text { Ocorrência de debates. }\end{array}$ & $\begin{array}{l}03 \\
06\end{array}$ & $\begin{array}{c}03 \\
-\end{array}$ \\
\hline 4. Comunicações interpessoais & Ocorrência entre as áreas. & 06 & - \\
\hline 5. Emoções & Expressão. & 04 & 02 \\
\hline 6. Pensar, sentir e agir & Evidência de interface. & 05 & 01 \\
\hline 7. Tomada de decisão & Ocorrência de em grupo. & 05 & 01 \\
\hline 8. Comportamento intergrupal & Favorecendo o trabalho em equipe. & 04 & 02 \\
\hline 9. Participação & Estímulo à atitude de participação do empregado. & 04 & 02 \\
\hline 10. Envolvimento & $\begin{array}{l}\text { Estímulo à atitude de envolvimento do empregado } \\
\text { com os objetivos organizacionais. }\end{array}$ & 03 & 03 \\
\hline 11. Comprometimento & $\begin{array}{l}\text { Estímulo à atitude de comprometimento do } \\
\text { empregado com os objetivos organizacionais. }\end{array}$ & 05 & 01 \\
\hline 12. Expectativas & $\begin{array}{l}\text { Possibilidade de o empregado comunicar expecta- } \\
\text { tivas em relação à unidade; } \\
\text { Ocorrência de comunicação das expectativas da } \\
\text { unidade em relação ao empregado. }\end{array}$ & $\begin{array}{l}05 \\
02\end{array}$ & $\begin{array}{l}01 \\
04\end{array}$ \\
\hline 13. Responsabilidades & $\begin{array}{l}\text { Estímulo para o empregado assumir responsabili- } \\
\text { dades sobre suas ações. }\end{array}$ & 05 & 01 \\
\hline 14. Engajamento & $\begin{array}{l}\text { Estímulo ao engajamento das pessoas aos objetivos } \\
\text { e metas organizacionais. }\end{array}$ & 06 & - \\
\hline 15. Características da unidade & $\begin{array}{l}\text { Estimulando as pessoas a despenderem esforços } \\
\text { para nela permanecerem. }\end{array}$ & 02 & 04 \\
\hline 16. Cooperação & $\begin{array}{l}\text { Estímulo à atitude de cooperação; } \\
\text { Evidência da cooperação. }\end{array}$ & $\begin{array}{l}02 \\
06\end{array}$ & $\begin{array}{c}04 \\
-\end{array}$ \\
\hline 17. Valorização & $\begin{array}{l}\text { Evidência da valorização de opiniões e descobertas } \\
\text { em relação à maneira de se obter resultados; } \\
\text { Evidência da valorização do trabalho. }\end{array}$ & $\begin{array}{l}02 \\
05\end{array}$ & $\begin{array}{l}04 \\
01\end{array}$ \\
\hline 18. Aprendizagem/reaprendizagem & $\begin{array}{l}\text { Reconhecimento da necessidade de aprendiza- } \\
\text { gem/reaprendizagem em relação ao trabalho. }\end{array}$ & 03 & 03 \\
\hline 19. Desenvolvimento & $\begin{array}{l}\text { Demonstração do estímulo ao desenvolvimento } \\
\text { pessoal e profissional na própria organização. }\end{array}$ & 05 & 01 \\
\hline 20. Incentivos & $\begin{array}{l}\text { Disponibilização de incentivos vinculados a } \\
\text { resultados obtidos pela equipe. }\end{array}$ & 04 & 02 \\
\hline 21. Reconhecimento & $\begin{array}{l}\text { As pessoas são capazes de: desenvolvimento, } \\
\text { confiança e colaboração. }\end{array}$ & 05 & 01 \\
\hline $\begin{array}{l}\text { 22. Características organizacionais } \\
\text { da unidade }\end{array}$ & $\begin{array}{l}\text { Atrair e reter pessoas de alto potencial e qualifi- } \\
\text { cação para o trabalho. }\end{array}$ & 01 & 05 \\
\hline $\begin{array}{l}\text { 23. Criação de condições de trabalho } \\
\text { na unidade }\end{array}$ & $\begin{array}{l}\text { Favoráveis à manutenção da motivação individual } \\
\text { para o trabalho; } \\
\text { Favoráveis à mobilização dos grupos em torno das } \\
\text { metas organizacionais. }\end{array}$ & $\begin{array}{l}02 \\
04\end{array}$ & $\begin{array}{l}04 \\
02\end{array}$ \\
\hline $\begin{array}{l}\text { 24. Estrutura organizacional da } \\
\text { unidade }\end{array}$ & $\begin{array}{l}\text { Valorizando somente o que a liderança determina; } \\
\text { Valorizando a iniciativa individual; } \\
\text { Valorizando o poder concentrado na liderança; } \\
\text { Valorizando a responsabilidade compartilhada. }\end{array}$ & $\begin{array}{l}02 \\
05 \\
01 \\
05\end{array}$ & $\begin{array}{l}04 \\
01 \\
05 \\
01\end{array}$ \\
\hline 25. Comunicação & $\begin{array}{l}\text { Acerca do que é esperado do desempenho das } \\
\text { pessoas; } \\
\text { Dos acontecimentos críticos que marcam a história } \\
\text { da unidade; } \\
\text { Ocupação da unidade em saber como está sendo } \\
\text { percebido o seu processo de comunicação formal e } \\
\text { informal. }\end{array}$ & $\begin{array}{l}03 \\
04 \\
02\end{array}$ & $\begin{array}{l}03 \\
02 \\
04\end{array}$ \\
\hline 26. Missão organizacional & $\begin{array}{l}\text { Ocupação da unidade em saber como está sendo } \\
\text { compreendida sua missão. }\end{array}$ & 02 & 04 \\
\hline
\end{tabular}




\begin{tabular}{|l|l|c|c|}
\hline \multirow{2}{*}{$\begin{array}{c}\text { Unidade de Codificação } \\
\text { Palavras-tema }\end{array}$} & \multicolumn{1}{|c|}{ Palavras-chave ou Frases-chave } & \multicolumn{2}{c|}{ Contagem } \\
\cline { 2 - 4 } & $\begin{array}{l}\text { Pemonstração dos valores pelos quais se rege a } \\
\text { unidade; } \\
\text { 27. Valores }\end{array}$ & $\begin{array}{l}\text { Ausência } \\
\text { da coerência entre os valores e o sistema de gestão } \\
\text { da unidade. }\end{array}$ & 05 \\
\hline 28. Políticas & $\begin{array}{l}\text { Criação das condições de adaptação de políticas } \\
\text { integradas de recursos humanos à realidade da } \\
\text { organização e ao seu contexto de atuação dessa } \\
\text { unidade remota. }\end{array}$ & 04 \\
\hline \multicolumn{2}{|l}{ Fonte: a autora, com base nos dados da pesquisa. } \\
\hline
\end{tabular}

As unidades de codificação 1 a 8 dizem respeito às palavras-tema contidas nos aspectos do comportamento organizacional. A contagem de presenças totalitárias nas unidades de codificação 1 (palavra-chave 2), 3 (frase-chave 2) e 4, seguida de presenças expressivas nas unidades 2, 6 e 7 e substanciais nas unidades de codificação 1 (palavra-chave1), 5 e 8 , mostra uma visão favorável dos entrevistados em relação aos aspectos ligados ao comportamento organizacional. As ausências contidas nas palavras-tema da unidade de codificação 3 equiValem-se às presenças, não são desprezíveis e podem ser conduzidas a um diálogo investigativo das razões.

As unidades de codificação 9 a 16 estão voltadas para as palavras-tema contidas nos aspectos do comprometimento organizacional. A contagem de presenças é totalitária nas unidades de codificação 14 e 16 (frase-chave 2), expressiva nas unidades de codificação 11, 12 (frasechave1) e 13 e substancial na 9, o que denota favorabilidade, na percepção dos entrevistados, com relação a esses aspectos voltados para o comprometimento . A unidade de codificação 10 mostra equilíbrio entre presenças e ausências; As unidades de codificação 12 (frase-chave 2), 15 e 16 (frase-chave 1) mostram que as ausências são significativas e superiores às presenças, indicando necessidade de investigação das razões que estão nelas embutidas.

As unidades de codificação 17 a 23 referem-se às palavras-tema contidas nos aspectos de gestão estratégica de pessoas. As presenças são quase totalizadoras nas unidades de codificação 17 (frase-chave 2), 19 e 21; substanciais nas unidades de codificação 20 e 23 (frasechave 2), o que mostra favorabilidade nesses aspectos de gestão de pessoas. Entretanto, as ausências observadas nas unidades de codificação 17 (frase-chave 1), 18 (eqüitativas com as presenças), 19, 20, 22 (principalmente pela superioridade), e 23 (frase-chave 1, também superiores às presenças), denotam necessidade de investigação para a compreensão das razões que determinam esses resultados. 
As unidades de codificação 24 a 28 estão no bojo das palavras-tema contidas nos aspectos da cultura organizacional. Ressaltem-se, nesse quadro, as ausências na unidade de codificação 24 - estrutura organizacional, com as frases-chave "valorizando somente o que a liderança determina" e "valorizando o poder concentrado na liderança", as quais podem denotar flexibilidade e falta de centralização, resultando em percepção positiva dos entrevistados, desses aspectos, nessa unidade remota. Do mesmo modo, nessa mesma unidade de codificação, as presenças nas frases-chave "valorizando a responsabilidade compartilhada" e "valorizando a iniciativa individual", apresentam-se como confirmatórias do significado das ausências salientadas.

As unidades de codificação 25 (frases-chave 1 e 3), 26 e 27 (frase-chave 2) apresentam ausências substanciais, podendo denotar necessidade de investigação das prováveis causas dessas ausências, na medida em que elas podem indicar percepções desfavoráveis, na visão dos entrevistados, no que tange aos aspectos concernentes à cultura organizacional dessa unidade remota. As presenças encontradas nas unidades de codificação 25 (frase-chave 2), 27 (frase-chave 1) e 28, apresentam percepções favoráveis desses mesmos aspectos, na ótica desses entrevistados.

O quadro $n^{\circ} .23$ apresenta o resultado da análise de conteúdo aplicadado ao escopo da pesquisa nessa unidade remota e contribui para aprofundar a compreensão do que foi mostrado no quadro $n^{\circ} .22$.

\begin{tabular}{|c|c|c|}
\hline \multicolumn{3}{|c|}{$\begin{array}{l}\text { QUADRO No } \text { Q }^{\circ} 2 \\
\text { RESULTADO DA ANÁLISE DE CONTEÚDO APLICADO AO ESCOPO DA PESQUISA } \\
\text { UNIDADE JARÍ CELULOSE }\end{array}$} \\
\hline Categorias de Análise & $\begin{array}{c}\text { Temas } \\
\text { Significativos } \\
\end{array}$ & Unidade de Codificação \\
\hline $\begin{array}{c}\text { Comportamento } \\
\text { Organizacional }\end{array}$ & $\begin{array}{l}\text { Percepção da con- } \\
\text { tribuição dos indi- } \\
\text { víduos, dos grupos e } \\
\text { da estrutura. }\end{array}$ & $\begin{array}{l}\text { "As pessoas individualmente e em grupos impactam a unidade de duas } \\
\text { maneiras: apresentando resultados elevados de produção e } \\
\text { constantemente mostrando o risco de alta rotatividade." } \\
\text { "A unidade apresenta estrutura que atrai mais as pessoas em início de } \\
\text { carreira." } \\
\text { "A participação das pessoas da unidade em eventos sociais e em } \\
\text { treinamentos abertos para pessoas que não têm oportunidade é um } \\
\text { marco a ser registrado." }\end{array}$ \\
\hline $\begin{array}{c}\text { Comprometimento } \\
\text { Organizacional }\end{array}$ & $\begin{array}{l}\text { Percepção do orgu- } \\
\text { lho e do empenho } \\
\text { exercido pelos in- } \\
\text { divíduos em favor } \\
\text { dessa unidade re- }\end{array}$ & $\begin{array}{l}\text { "O orgulho é demonstrado pelo fato de trabalhar em um grupo do } \\
\text { porte ORSA." } \\
\text { "Há muito comprometimento de todos que se adaptam às pecu- } \\
\text { liaridades da unidade." }\end{array}$ \\
\hline
\end{tabular}




\begin{tabular}{|c|c|c|}
\hline & mota. & $\begin{array}{l}\text { "O orgulho é expresso mais pelos funcionários antigos. O empenho é } \\
\text { visível com os resultados de produção." } \\
\text { "As pessoas são mais comprometidas, quando gostam de morar em } \\
\text { estruturas isoladas e criar os filhos com mais liberdade." }\end{array}$ \\
\hline Categorias de Análise & $\begin{array}{c}\text { Temas } \\
\text { Significativos } \\
\end{array}$ & Unidade de Codificação \\
\hline $\begin{array}{c}\text { Gestão Estratégica de } \\
\text { Pessoas }\end{array}$ & $\begin{array}{l}\text { Percepção da adoção } \\
\text { de novas práticas de } \\
\text { gestão, de modo a } \\
\text { facilitar as ações de } \\
\text { desenvolvimento e } \\
\text { resolução de conflitos } \\
\text { nessa unidade re- } \\
\text { mota. }\end{array}$ & $\begin{array}{l}\text { "As práticas de gestão de pessoas estão centralizadas na corporação." } \\
\text { "Para as especificidades da região são oferecidos incentivos } \\
\text { financeiros, incluindo a residência montada, água e luz incluídas." } \\
\text { "Existem projetos internos para as ações de desenvolvimento e } \\
\text { participação em programas externos vinculados a algumas univer- } \\
\text { sidades." }\end{array}$ \\
\hline $\begin{array}{c}\text { Cultura } \\
\text { Organizacional }\end{array}$ & $\begin{array}{l}\text { Percepção do conhe- } \\
\text { cimento que os indi- } \\
\text { víduos têm, acerca da } \\
\text { visão, filosofia de } \\
\text { atuação, missão e } \\
\text { valores nessa uni- } \\
\text { dade remota. }\end{array}$ & $\begin{array}{l}\text { "A integração entre a empresa e a comunidade é um ponto que sempre } \\
\text { precisa ser tratado com cuidado." } \\
\text { "O processo de lembrar a cultura da unidade é continuamente feito } \\
\text { pelos gestores." } \\
\text { "As pessoas comprometem-se com a cultura de responsabilidade } \\
\text { econômica, social e ambiental." } \\
\text { "O movimento corporativo, muitas vezes é compreendido pelos } \\
\text { funcionários como inadequado para a unidade." }\end{array}$ \\
\hline & & m base nos dados da pesquisa. \\
\hline
\end{tabular}

A unidade atrai jovens que, muitas vezes, têm dificuldades de adaptação às peculiaridades da região. Às vezes, quando o funcionário se adapta, corre o risco da família querer ir embora porque não se acostuma ao local. A questão como a gestão de pessoas facilita ou dificulta a obtenção do comprometimento é respondida nessa unidade a partir dos parágrafos subseqüentes.

As peculiaridades exigem ações de gestão de pessoas que reflitam, muito rapidamente, a realidade de reconhecimento e valorização das pessoas que, por vezes, extrapolam para a vida pessoal o valor da união e do comprometimento em situação de dificuldade e isso merece registro, segundo os dados da pesquisa. A unidade investe e oportuniza o crescimento profissional dos seus funcionários por intermédio do estímulo à educação. Por sua vez, eles contribuem com conhecimentos, capacidades e habilidades, proporcionando decisões e ações que dinamizam a unidade e a organização.

As principais ações de investimento na gestão de pessoas estão voltadas para o conhecimento e educação, desde a educação escolar básica, curso técnico até a especialização para profissionais graduados. A empresa mantém vínculo com a Faculdade de Medicina da Universidade Federal do Pará, visando a promoção da saúde e atendimento das necessidades da comunidade. 
Outro registro, feito pelos entrevistados, é com relação à atenção dispensada aos problemas de adaptação das pessoas que chegam de fora da região. Os resultados da pesquisa mostram que, por se tratar de uma unidade com uma realidade ímpar, localizada em região remota, isolada e confinada, há clareza de que ela precisa oferecer aos seus funcionários o bem-estar integral no trabalho, com a família e na comunidade. Assim, essa unidade promove eventos sociais que propiciam aos seus funcionários e suas famílias, momentos de integração, esporte, diversão e lazer. Incentiva a responsabilidade social, um exercício praticado voluntariamente pelos seus funcionários, com a finalidade de contribuir com o desenvolvimento das pessoas e melhoria na qualidade de vida.

Ela dispõe de moderna tecnologia de gestão de pessoas que consiste em vários processos, como planejamento e realização de seleção, admissão, integração, administração de cargos e salários, incentivos e benefícios, monitoramento, segurança e medicina do trabalho, treinamento e desenvolvimento de pessoas. Entretanto, as práticas muitas vezes não facilitam a retenção de pessoas por mais de três ou quatro anos e isso implica na dificuldade de resolver conflitos inerentes às especificidades da unidade. As pessoas participam dos programas internos e externos e, muitas vezes, estimulam-se a fazer outras coisas, quer no mercado quer nas universidades. Segundo os entrevistados, isso reduz a possibilidade de retenção desses talentos na unidade.

Por mais que a intenção da corporação seja fazer o melhor, os entrevistados afirmam que a cultura de autonomia para a unidade é vista como passível de melhorias. A estrutura de assistência médica apresenta-se em momento de grande dificuldade, até certo ponto, crítica. $\mathrm{O}$ hospital local não atende todas as demandas e a estrutura com deslocamentos em UTI aérea é muito dispendiosa. Isso contribui, também, para a insegurança das pessoas em se manterem na unidade. O quadro reduzido agrava o cansaço físico e mental. Por outro lado esses entrevistados reforçam que o alto empenho vem de dentro, da automotivação das pessoas, por sentirem o orgulho interior pelo trabalho engenhoso que realizam.

De acordo com os dados da pesquisa há uma grande rotatividade de gestores, o que acarreta dificuldades adicionais na forma de gestão. Os entrevistados consideram que as mudanças na estrutura não facilitam a gestão das pessoas que colaboram nessa unidade. Com os gestores ficando em São Paulo é salientada a perda da comunicação com a hierarquia, aumentando a distância e diminuindo a velocidade para resolução dos problemas da unidade. Esses 
entrevistados reforçam que as especificidades precisam ser compreendidas pelos gestores para que eles possam atuar como facilitadores. Isso não é possível, em razão dessa distância.

Contudo, as pessoas entrevistadas afirmam que, principalmente as mais antigas, expressam o orgulho de estar na unidade e na região, com brilho nos olhos. Muito embora os dados das entrevistas reforcem a questão do orgulho vinculada à satisfação pessoal em fazer bem feito, reafirmam que os resultados operacionais têm se mantido elevado em toda a unidade.

É um dado unânime das entrevistas, que a unidade está passando por momento delicado, em virtude das mudanças de gestão de pessoas ocorridas com a aquisição pelo Grupo Orsa. Algumas práticas consideradas paternalistas estão sendo revistas e, não obstante, os resultados dessas unidades se mantêm elevados. A premissa que envolve tal empenho é a de que ele ocorre em prol da satisfação própria de cada pessoa em fazer o seu trabalho bem feito, do que propriamente em prol da organização, a ponto de atribuir-lhe mérito da obtenção do comprometimento.

Eles consideram que a perda do anonimato provocado pela proximidade diária é oriunda da riqueza do aprendizado com a diversidade cultural dos integrantes dessa unidade. Reforce-se que os dados da pesquisa, nessa unidade, apesar das dificuldades registradas, mostram chefias e colegas de todas as áreas e/ou da mesma área estimulando: feedbacks, debates, cooperação, valorização do trabalho, reconhecimento pela capacidade de desenvolvimento, confiabilidade e colaboração. Nesse ponto dá-se o cruzamento dos aspectos ligados a comportamento, comprometimento, gestão de pessoas e cultura organizacional, detalhados no quadro $n^{\circ} 22$.

\section{3. 2 Unidade: Orsa Florestal}

A Jari Celulose, no desenvolvimento de seus processos florestais, tem como política "atender a demanda por seus produtos, utilizando tecnologias que assegurem qualidade, produtividade e competitividade em harmonia com o meio-ambiente".

A gestão ambiental da empresa está voltada, dentre outras coisas, para "identificar e minimizar os impactos ambientais adversos decorrentes de suas atividades e de seus produtos e no desenvolvimento de novas tecnologias aliadas com a prevenção da poluição, contempladas nos objetivos e metas ambientais". 
A empresa domina a tecnologia de cultivo de eucaliptos em região equatorial e, ao longo das três últimas décadas, desenvolveu pesquisas intensivas nas quais diversas espécies foram testadas. Essas pesquisas geraram um conhecimento estratégico valioso sobre as espécies que melhor se adaptam à região amazônica, viabilizando a utilização exclusivamente do eucalipto como fonte de matéria-prima para a produção de celulose nessa região.

As mudas da Jari são produzidas em um viveiro próprio, com capacidade de produção de doze milhões de mudas. Desde o início das atividades florestais, foi introduzido material genético, a partir do qual se estabeleceu o programa de melhoramento genético das espécies da empresa, o que permite a identificação da melhor técnica de preparo de solo e fertilização, a ser adotada para cada situação, além de ser de grande utilidade no planejamento das operações florestais.

Visando estar sempre atualizada tecnologicamente, a Jari mantém projetos de pesquisa e desenvolvimento, em conjunto com universidades e instituições de pesquisas do Brasil e do Exterior.

As plantações de eucalipto da unidade obedecem a um modelo de ocupação planejada e são permeadas por reservas nativas de floresta amazônica, com ecossistemas diversificados. Corredores de floresta virgem são mantidos entre as plantações, permitindo, assim, a livre circulação da fauna local. Esses corredores, também, oferecem proteção natural contra pragas, garantindo o equilíbrio ecológico, sem o uso de agrotóxicos.

Nos plantios da empresa, o desenvolvimento genético vem sendo conduzido pelo uso de técnicas convencionais, não tendo sido utilizadas técnicas de geração de árvores geneticamente modificadas.

O sistema de cultivo mínimo é utilizado para o plantio do eucalipto, o que gera uma série de benefícios ambientais como: conservação da biomassa recobrindo o solo, manutenção da fauna e da matéria orgânica existente no local, entre outros.

O quadro $n^{\circ} .24$ apresenta o resultado da análise de conteúdo da entrevista realizada nessa unidade. 


\begin{tabular}{|c|c|c|c|}
\hline \multicolumn{4}{|c|}{$\begin{array}{c}\text { QUADRO Nº } 24 \\
\text { RESULTADO DA ANÁLISE DE CONTEÚDO UNIDADE ORSA FLORESTAL }\end{array}$} \\
\hline \multirow{2}{*}{$\begin{array}{l}\text { Unidade de Codificação } \\
\text { Palavras-tema }\end{array}$} & \multirow[t]{2}{*}{ Palavras-chave ou Frases-chave } & \multicolumn{2}{|c|}{ Contagem } \\
\hline & & Presença & Ausência \\
\hline 1. Feedback & $\begin{array}{l}\text { Estímulo; } \\
\text { Evidência. }\end{array}$ & - & $\begin{array}{c}01 \\
-\end{array}$ \\
\hline 2. Interações & Integrantes dos diversos escalões. & 01 & - \\
\hline 3. Abertura & $\begin{array}{l}\text { Encorajamento para debates; } \\
\text { Ocorrência de debates. }\end{array}$ & $\overline{0}$ & $\begin{array}{c}01 \\
-\end{array}$ \\
\hline 4. Comunicações interpessoais & Ocorrência entre as áreas. & 01 & - \\
\hline 5. Emoções & Expressão. & - & 01 \\
\hline 6. Pensar, sentir e agir & Evidência de interface. & 01 & - \\
\hline 7. Tomada de decisão & Ocorrência de em grupo. & 01 & - \\
\hline 8. Comportamento intergrupal & Favorecendo o trabalho em equipe. & 01 & - \\
\hline 9. Participação & Estímulo à atitude de participação do empregado. & 01 & - \\
\hline 10. Envolvimento & $\begin{array}{l}\text { Estímulo à atitude de envolvimento do empregado } \\
\text { com os objetivos organizacionais. }\end{array}$ & 01 & - \\
\hline 11. Comprometimento & $\begin{array}{l}\text { Estímulo à atitude de comprometimento } \\
\text { (identificação) do empregado com os objetivos } \\
\text { organizacionais. }\end{array}$ & 01 & - \\
\hline 12. Expectativas & $\begin{array}{l}\text { Possibilidade de o empregado comunicar expecta- } \\
\text { tivas em relação à unidade; } \\
\text { Ocorrência de comunicação das expectativas da } \\
\text { unidade em relação ao empregado. }\end{array}$ & $\begin{array}{l}- \\
01\end{array}$ & 01 \\
\hline 13. Responsabilidades & $\begin{array}{l}\text { Estímulo para o empregado assumir responsabili- } \\
\text { dades sobre suas ações. }\end{array}$ & 01 & - \\
\hline 14. Engajamento & $\begin{array}{l}\text { Estímulo para o engajamento das pessoas aos } \\
\text { objetivos e metas organizacionais. }\end{array}$ & 01 & - \\
\hline 15. Características da unidade & $\begin{array}{l}\text { Estimulando as pessoas a despenderem esforços } \\
\text { para nela permanecerem. }\end{array}$ & - & 01 \\
\hline 16. Cooperação & $\begin{array}{l}\text { Estímulo à atitude de cooperação; } \\
\text { Evidência da cooperação. }\end{array}$ & $\begin{array}{l}01 \\
01\end{array}$ & - \\
\hline 17. Valorização & $\begin{array}{l}\text { Evidência da valorização de opiniões e descobertas } \\
\text { em relação à maneira de se obter resultados; } \\
\text { Evidência da valorização do trabalho. }\end{array}$ & - & $\begin{array}{l}01 \\
- \\
\end{array}$ \\
\hline 18. Aprendizagem/reaprendizagem & $\begin{array}{l}\text { Reconhecimento da necessidade de apren- } \\
\text { dizagem/reaprendizagem em relação ao trabalho. }\end{array}$ & 01 & - \\
\hline 19. Desenvolvimento & $\begin{array}{l}\text { Demonstração do estímulo ao desenvolvimento } \\
\text { pessoal e profissional na própria organização. }\end{array}$ & 01 & - \\
\hline 20. Incentivos & $\begin{array}{l}\text { Disponibilização de incentivos vinculados a } \\
\text { resultados obtidos pela equipe. }\end{array}$ & 01 & - \\
\hline 21. Reconhecimento & $\begin{array}{l}\text { As pessoas são capazes de: desenvolvimento, } \\
\text { confiança e colaboração. }\end{array}$ & 01 & - \\
\hline $\begin{array}{l}\text { 22. Características organizacionais } \\
\text { da unidade }\end{array}$ & $\begin{array}{l}\text { Atrair e reter pessoas de alto potencial e } \\
\text { qualificação para o trabalho. }\end{array}$ & 01 & - \\
\hline $\begin{array}{l}\text { 23. Criação de condições de trabalho } \\
\text { na unidade }\end{array}$ & $\begin{array}{l}\text { Favoráveis à manutenção da motivação individual } \\
\text { para o trabalho; } \\
\text { Favoráveis à mobilização dos grupos em torno das } \\
\text { metas organizacionais. }\end{array}$ & $\begin{array}{l}- \\
01\end{array}$ & 01 \\
\hline $\begin{array}{l}\text { 24. Estrutura organizacional da } \\
\text { unidade }\end{array}$ & $\begin{array}{l}\text { Valorizando somente o que a liderança detemina; } \\
\text { Valorizando a iniciativa individual; } \\
\text { Valorizando o poder concentrado na liderança; } \\
\text { Valorizando a responsabilidade compartilhada. }\end{array}$ & $\begin{array}{c}- \\
01 \\
- \\
01\end{array}$ & $\begin{array}{c}01 \\
- \\
01 \\
-\end{array}$ \\
\hline 25. Comunicação & $\begin{array}{l}\text { Acerca do que é esperado do desempenho das } \\
\text { pessoas; } \\
\text { Dos acontecimentos críticos que marcam a história } \\
\text { da unidade; } \\
\text { Ocupação da unidade em saber como está sendo } \\
\text { percebido o seu processo de comunicação formal e } \\
\text { informal. }\end{array}$ & $\begin{array}{l}01 \\
01 \\
01\end{array}$ & $\begin{array}{l}- \\
- \\
-\end{array}$ \\
\hline 26. Missão organizacional & $\begin{array}{l}\text { Ocupação da unidade em saber como está sendo } \\
\text { compreendida sua missão. }\end{array}$ & - & 01 \\
\hline
\end{tabular}




\begin{tabular}{|c|c|c|c|}
\hline \multirow{2}{*}{$\begin{array}{c}\text { Unidade de Codificação } \\
\text { Palavras-tema }\end{array}$} & \multirow[t]{2}{*}{ Palavras-chave ou Frases-chave } & \multicolumn{2}{|c|}{ Contagem } \\
\hline & & Presença & Ausência \\
\hline 27. Valores & $\begin{array}{l}\text { Demonstração dos valores pelos quais se rege a } \\
\text { unidade; } \\
\text { Comunicação e/ou constatação, pelos empregados, } \\
\text { da coerência entre os valores e o sistema de gestão } \\
\text { da unidade. }\end{array}$ & $\begin{array}{l}01 \\
01\end{array}$ & $\begin{array}{l}- \\
-\end{array}$ \\
\hline 28. Políticas & $\begin{array}{l}\text { Criação das condições de adaptação de políticas } \\
\text { integradas de recursos humanos à realidade da } \\
\text { organização e ao seu contexto de atuação nessa } \\
\text { unidade remota. }\end{array}$ & - & 01 \\
\hline
\end{tabular}

As unidades de codificação 1 a 8 dizem respeito às palavras-tema contidas nos aspectos do comportamento organizacional. A presença está registrada nas unidades de codificação 1 (palavra-chave 2), 2, 3 (frase-chave 2), 4, 6, 7 e 8. A ausência, apenas nas unidades de codificação 1 (palavra chave1), 3 (frase-chave 1) e 5.

As unidades de codificação 9 a 16 estão voltadas para as palavras-tema contidas nos aspectos do comprometimento organizacional. A presença é mostrada nas unidades de codificação 9 , 10, 11, 12 (frase-chave 2), 13, 14 e 16 (ambas as frases-chave). As unidades de codificação 12 (frase-chave 1) e 15 mostram que a ausência representa necessidade de investigação do que está ocorrendo.

As unidades de codificação 17 a 23 referem-se às palavras-tema contidas nos aspectos de gestão estratégica de pessoas. A presença é marcada nas unidades de codificação 17 (frasechave 2), 18, 19, 20, 21, 22 e 23 (frase-chave 2). A ausência é observada apenas na unidade de codificação 23 (frase-chave 1).

As unidades de codificação 24 a 28 estão no bojo das palavras-tema contidas nos aspectos da cultura organizacional. Atente-se, nesse quadro, para a ausência encontrada na unidade de codificação 24 - estrutura organizacional da unidade, com as frases-chave "valorizando somente o que a liderança determina" e "valorizando o poder concentrado na liderança". Tal registro mostra o aspecto positivo da falta de centralização, o que é reforçado pela presença das frases-chave "valorizando a responsabilidade compartilhada" e "valorizando a iniciativa individual", representando a visão de descentralização e de flexibilidade percebida na entrevista. 
As unidades de codificação 25 e 27 apresentam presença e as 26 e 28 apresentam ausência, no que tange aos aspectos concernentes à cultura dessa unidade remota. Os resultados dessa entrevista mostam-se favoráveis.

O quadro $\mathrm{n}^{\mathrm{o}}$. 25 apresenta o resultado da análise de conteúdo aplicadado ao escopo da pesquisa nessa unidade remota e contribui para aprofundar a compreensão do que foi mostrado no quadro $\mathrm{n}^{\circ} .24$.

\begin{tabular}{|c|c|c|}
\hline \multicolumn{3}{|c|}{$\begin{array}{l}\text { QUADRO No.25 } \\
\text { RESULTADO DA ANÁLISE DE CONTEÚDO APLICADO AO ESCOPO DA PESQUISA } \\
\text { UNIDADE ORSA FLORESTAL }\end{array}$} \\
\hline $\begin{array}{l}\text { Categorias de } \\
\text { Análise }\end{array}$ & Temas Significativos & Unidade de Codificação \\
\hline $\begin{array}{c}\text { Comportamento } \\
\text { Organizacional }\end{array}$ & $\begin{array}{l}\text { Percepção da con- } \\
\text { tribuição dos indiví- } \\
\text { duos, dos grupos e da } \\
\text { estrutura. }\end{array}$ & $\begin{array}{l}\text { "As ações das pessoas se refletem rapidamente dentro e fora da } \\
\text { unidade, por causa da convivência próxima. Isso pode ser positivo ou } \\
\text { negativo." }\end{array}$ \\
\hline $\begin{array}{c}\text { Comprometimento } \\
\text { Organizacional }\end{array}$ & $\begin{array}{l}\text { Percepção do orgulho e } \\
\text { do empenho exercido } \\
\text { pelos indivíduos em } \\
\text { favor dessa unidade. }\end{array}$ & $\begin{array}{l}\text { "O orgulho de trabalhar em um grande grupo é alto. O apoio recebido } \\
\text { é retribuído pelo empenho no alcance dos objetivos." }\end{array}$ \\
\hline $\begin{array}{l}\text { Gestão Estratégica } \\
\text { de Pessoas }\end{array}$ & $\begin{array}{l}\text { Percepção da adoção de } \\
\text { novas práticas de } \\
\text { gestão, de modo a } \\
\text { facilitar as ações de } \\
\text { desenvolvimento e } \\
\text { resolução de conflitos } \\
\text { nessa unidade. }\end{array}$ & $\begin{array}{l}\text { "Como o grupo dispõe de uma boa estrutura corporativa, temos } \\
\text { sempre contato com o que está sendo praticado nos grandes centros e } \\
\text { não nos sentimos isolados apesar de estarmos em localidade remota. } \\
\text { As adaptações para a localidade ficam com a sensibilidade dos } \\
\text { gestores." }\end{array}$ \\
\hline $\begin{array}{c}\text { Cultura } \\
\text { Organizacional }\end{array}$ & $\begin{array}{l}\text { Percepção do conhe- } \\
\text { cimento que os indi- } \\
\text { víduos têm, acerca da } \\
\text { visão, filosofia de } \\
\text { atuação, missão e } \\
\text { valores nessa unidade } \\
\text { remota. }\end{array}$ & $\begin{array}{l}\text { "É grande a diferença percebida entre os níveis hierárquicos na } \\
\text { compreensão da visão, filosofia de atuação, missão e valores da } \\
\text { unidade." }\end{array}$ \\
\hline & onte: a aut & dados da pe \\
\hline
\end{tabular}

Os dados da entrevista mostram que, para a implantação, em escala comercial, de toda a tecnologia que vem sendo desenvolvida na Jari, tem sido estratégica a preocupação com o treinamento e reciclagem dos recursos humanos próprios e das empresas prestadoras de serviços, com vistas à formação da base de competitividade sustentável da empresa.

A unidade tem vivido problema de alta rotatividade da mão-de-obra, no nível operacional, atribuída à questão de baixa qualificação, necessitando recrutar fora da região, com o risco de 
dificuldades na adaptação dos candidatos e dos seus familiares. No nível gerencial, as pessoas são recrutadas naturalmente fora, em vários grandes centros urbanos do país.

Relembre-se que os dados da pesquisa nessa unidade, apesar das dificuldades registradas, acima, mostram chefias e colegas de todas as áreas e/ou da mesma área estimulando: feedbacks, debates, cooperação, valorização do trabalho, reconhecimento pela capacidade de desenvolvimento, confiabilidade e colaboração. Nesse ponto dá-se o cruzamento dos aspectos ligados a comportamento, comprometimento, gestão de pessoas e cultura organizacional, detalhados no quadro $\mathrm{n}^{\circ} .24$.

\section{3. 3 Unidade: Fundação Orsa}

Desde sua origem, o Grupo Orsa assumiu um compromisso com a luta contra a desigualdade social no Brasil. Para coordenar e centralizar a atuação do Grupo na área da ação social foi criada em 1994 a Fundação Orsa, uma instituição sem fins lucrativos que desenvolve programas nas áreas de educação, saúde, promoção social, voluntariado e meio-ambiente, focados em sua missão de "promover a formação integral da criança e do adolescente em situação de risco pessoal e social, nas áreas de educação, saúde e promoção social".

Com a aquisição da Jari Celulose pelo Grupo Orsa, em fevereiro de 2000, a Fundação Orsa instalou uma nova unidade no norte do país, em Monte Dourado, entre os Estados do Amapá e Pará. Essa unidade recebe $1 \%$ do faturamento anual da Jari, caracterizado como recurso semente.

Atualmente, a Fundação também foca suas ações no fortalecimento de políticas públicas e no desenvolvimento sustentável de territórios, por meio de um modelo que integra ações ligadas aos âmbitos produtivo, social, ambiental e humano.

Atua como sementeira, estabelecendo um modelo de ação, que depois de testado e aprovado, consolida-se como uma semente que pode ser disseminada por ela ou por outras organizações, tanto do setor privado como do setor público, o que multiplica o seu alcance e impacto na sociedade. Dessa forma, cria, influencia e melhora políticas públicas, ao colocar esse conceito na prática, realizando mais de um milhão de atendimentos por ano. 
O modelo de atuação em rede envolve colaboradores, clientes e comunidades locais, além de universidades, órgãos governamentais, empresas e a sociedade civil organizada. $\mathrm{Na}$ unidade remota, isolada e confinada de Monte Dourado, a Fundação atende a crianças, adolescentes e adultos das localidades: Laranjal do Jari, Vitória do Jari, Vila do Panalto e Almeirim.

O quadro $\mathrm{n}^{\mathrm{o}} .26$ apresenta o resultado da análise de conteúdo da entrevista realizada nessa unidade.

\begin{tabular}{|c|c|c|c|}
\hline \multicolumn{4}{|c|}{$\begin{array}{l}\text { QUADRO Nº } 26 \\
\text { RESULTADO DA ANÁLISE DE CONTEÚDO UNIDADE FUNDAÇÃO ORSA }\end{array}$} \\
\hline \multirow{2}{*}{$\begin{array}{l}\text { Unidade de Codificação } \\
\text { Palavras-tema }\end{array}$} & \multirow[t]{2}{*}{ Palavras-chave ou Frases-chave } & \multicolumn{2}{|c|}{ Contagem } \\
\hline & & Presença & Ausência \\
\hline 1. Feedback & $\begin{array}{l}\text { Estímulo; } \\
\text { Evidência. }\end{array}$ & $\begin{array}{l}01 \\
01\end{array}$ & - \\
\hline 2. Interações & Integrantes dos diversos escalões. & 01 & - \\
\hline 3. Abertura & $\begin{array}{l}\text { Encorajamento para debates; } \\
\text { Ocorrência de debates. }\end{array}$ & $\begin{array}{l}01 \\
01\end{array}$ & - \\
\hline 4. Comunicações interpessoais & Ocorrência entre as áreas. & 01 & - \\
\hline 5. Emoções & Expressão. & 01 & - \\
\hline 6. Pensar, sentir e agir & Evidência de interface. & 01 & - \\
\hline 7. Tomada de decisão & Ocorrência de em grupo. & 01 & - \\
\hline 8. Comportamento intergrupal & Favorecendo o trabalho em equipe. & 01 & - \\
\hline 9. Participação & Estímulo à atitude de participação do empregado. & 01 & - \\
\hline 10. Envolvimento & $\begin{array}{l}\text { Estímulo à atitude de envolvimento do empregado } \\
\text { com os objetivos organizacionais. }\end{array}$ & 01 & - \\
\hline 11. Comprometimento & $\begin{array}{l}\text { Estímulo à atitude de comprometimento } \\
\text { (identificação) do empregado com os objetivos } \\
\text { organizacionais. }\end{array}$ & 01 & - \\
\hline 12. Expectativas & $\begin{array}{l}\text { Possibilidade de o empregado comunicar expecta- } \\
\text { tivas em relação à unidade; } \\
\text { Ocorrência de comunicação das expectativas da } \\
\text { unidade em relação ao empregado. }\end{array}$ & - & 01 \\
\hline 13. Responsabilidades & $\begin{array}{l}\text { Estímulo para o empregado assumir responsabili- } \\
\text { dades sobre suas ações. }\end{array}$ & 01 & - \\
\hline 14. Engajamento & $\begin{array}{l}\text { Estímulo para o engajamento das pessoas aos } \\
\text { objetivos e metas organizacionais. }\end{array}$ & 01 & - \\
\hline $\begin{array}{l}\text { 15. Características da orga- } \\
\text { nização/unidade }\end{array}$ & $\begin{array}{l}\text { Estimulando as pessoas a despenderem esforços } \\
\text { para nela permanecerem. }\end{array}$ & 01 & - \\
\hline 16. Cooperação & $\begin{array}{l}\text { Estímulo à atitude de cooperação; } \\
\text {.Evidência da cooperação. }\end{array}$ & $\begin{array}{l}01 \\
01\end{array}$ & - \\
\hline 17. Valorização & $\begin{array}{l}\text { Evidência da valorização de opiniões e desco- } \\
\text { bertas em relação à maneira de se obter resultados; } \\
\text { Evidência da valorização do trabalho. }\end{array}$ & 01 & - \\
\hline 18. Aprendizagem/reaprendizagem & $\begin{array}{l}\text { Reconhecimento da necessidade de aprendiza- } \\
\text { gem/reaprendizagem em relação ao trabalho. }\end{array}$ & 01 & - \\
\hline 19. Desenvolvimento & $\begin{array}{l}\text { Demonstração do estímulo ao desenvolvimento } \\
\text { pessoal e profissional na própria organização. }\end{array}$ & 01 & - \\
\hline 20. Incentivos & $\begin{array}{l}\text { Disponibilização de incentivos vinculados a } \\
\text { resultados obtidos pela equipe. }\end{array}$ & 01 & - \\
\hline 21. Reconhecimento & $\begin{array}{l}\text { As pessoas são capazes de: desenvolvimento, } \\
\text { confiança e colaboração. }\end{array}$ & 01 & - \\
\hline $\begin{array}{l}\text { 22. Características organizacionais } \\
\text { da unidade }\end{array}$ & $\begin{array}{l}\text { Atrair e reter pessoas de alto potencial e } \\
\text { qualificação para o trabalho. }\end{array}$ & - & 01 \\
\hline
\end{tabular}




\begin{tabular}{|c|c|c|c|}
\hline \multirow{2}{*}{$\begin{array}{l}\text { Unidade de Codificação } \\
\text { Palavras-tema }\end{array}$} & \multirow[t]{2}{*}{ Palavras-chave ou Frases-chave } & \multicolumn{2}{|c|}{ Contagem } \\
\hline & & Presença & Ausência \\
\hline $\begin{array}{l}\text { 23. Criação de condições de trabalho } \\
\text { na unidade }\end{array}$ & $\begin{array}{l}\text { Favoráveis à manutenção da motivação individual } \\
\text { para o trabalho; } \\
\text { Favoráveis à mobilização dos grupos em torno das } \\
\text { metas organizacionais. }\end{array}$ & $\begin{array}{l}01 \\
01\end{array}$ & - \\
\hline $\begin{array}{l}\text { 24. Estrutura organizacional da } \\
\text { unidade }\end{array}$ & $\begin{array}{l}\text { Valorizando somente o que a liderança determina; } \\
\text { Valorizando a iniciativa individual; } \\
\text { Valorizando o poder concentrado na liderança; } \\
\text { Valorizando a responsabilidade compartilhada. }\end{array}$ & $\begin{array}{c}- \\
01 \\
- \\
01\end{array}$ & $\begin{array}{l}01 \\
- \\
01 \\
-\end{array}$ \\
\hline 25. Comunicação & $\begin{array}{l}\text { Acerca do que é esperado do desempenho das } \\
\text { pessoas; } \\
\text { Dos acontecimentos críticos que marcam a história } \\
\text { da unidade; } \\
\text { Ocupação da unidade em saber como está sendo } \\
\text { percebido o seu processo de comunicação formal e } \\
\text { informal. }\end{array}$ & $\begin{array}{l}01 \\
01 \\
01\end{array}$ & $\begin{array}{l}- \\
- \\
-\end{array}$ \\
\hline 26. Missão organizacional & $\begin{array}{l}\text { Ocupação da unidade em saber como está sendo } \\
\text { compreendida sua missão. }\end{array}$ & 01 & - \\
\hline 27. Valores & $\begin{array}{l}\text { Demonstração dos valores pelos quais se rege a } \\
\text { unidade; } \\
\text { Comunicação e/ou constatação, pelos empregados, } \\
\text { da coerência entre os valores e o sistema de gestão } \\
\text { da unidade. }\end{array}$ & $\begin{array}{l}- \\
01\end{array}$ & 01 \\
\hline 28. Políticas & $\begin{array}{l}\text { Criação das condições de adaptação de políticas } \\
\text { integradas de recursos humanos à realidade da } \\
\text { organização e ao seu contexto de atuação nessa } \\
\text { unidade remota. }\end{array}$ & 01 & - \\
\hline
\end{tabular}

As unidades de codificação 1 a 8 dizem respeito às palavras-tema contidas nos aspectos do comportamento organizacional. A presença está registrada em todas as oito unidades de codificação, o que mostra favorabilidade com relação a esses aspectos do comportamento organizacional.

As unidades de codificação 9 a 16 estão voltadas para as palavras-tema contidas nos aspectos do comprometimento organizacional. A presença é mostrada nas unidades de codificação 9, $10,11,13,14$ e 16 (ambas as frases-chave), o que mostra posição favorável com relação aos aspectos do comprometimento nelas envolvidos. A unidade de codificação 12 mostra a ausência, em ambas as frases-chave, o que denota necessidade de investigação com outros integrantes dessa unidade remota, acerca das razões.

As unidades de codificação 17 a 23 referem-se às palavras-tema contidas nos aspectos de gestão estratégica de pessoas. A presença é marcada nas unidades de codificação $17,18,19$, 20, 21, e 23. A ausência é observada apenas na unidade de codificação 22 , o que mostra favorabilidade no que tange aos aspectos de gestão de pessoas nessa unidade remota. 
As unidades de codificação 24 a 28 estão no bojo das palavras-tema contidas nos aspectos da cultura organizacional. Observe-se, nesse quadro, a ausência encontrada na unidade de codificação 24 - estrutura organizacional da unidade, com as frases-chave "valorizando somente o que a liderança determina" e "valorizando o poder concentrado na liderança". Tal registro mostra o aspecto positivo da falta de centralização, o que é reforçado pela presença das frases-chave "valorizando a responsabilidade compartilhada" e "valorizando a iniciativa individual", podendo representar a visão da flexibilidade.

As unidades de codificação 25, 26, 27 (frase-chave 2) apresentam presença e apenas a 27 (frase-chave 1) apresenta ausência, no que tange aos aspectos concernentes à cultura organizacional dessa unidade remota. Tais resultados atestam a visão favorável nesses aspectos da cultura.

O quadro $\mathrm{n}^{\mathrm{o}} .27$ apresenta o resultado da análise de conteúdo aplicadado ao escopo da pesquisa nessa unidade remota e contribui para aprofundar a compreensão do que foi mostrado no quadro $\mathrm{n}^{\circ} .26$.

\begin{tabular}{|c|c|c|}
\hline \multicolumn{3}{|c|}{$\begin{array}{l}\text { QUADRO N.27 } \\
\text { RESULTADO DA ANÁLISE DE CONTEÚDO APLICADO AO ESCOPO DA PESQUISA FUNDAÇÃO ORSA }\end{array}$} \\
\hline $\begin{array}{c}\text { Categorias de } \\
\text { Análise }\end{array}$ & Temas Significativos & Unidade de Codificação \\
\hline $\begin{array}{c}\text { Comportamento } \\
\text { Organizacional }\end{array}$ & $\begin{array}{l}\text { Percepção da contribuição dos } \\
\text { indivíduos, dos grupos e da } \\
\text { estrutura. }\end{array}$ & $\begin{array}{l}\text { "As pessoas são produtivas, mas estão exigentes para que as } \\
\text { condições voltem a ser como antes. As unidades estão } \\
\text { atravessando um período difícil e muito delicado de como lidar } \\
\text { com esses comportamentos." }\end{array}$ \\
\hline $\begin{array}{l}\text { Comprometimento } \\
\text { Organizacional }\end{array}$ & $\begin{array}{lcc}\text { Percepção } & \text { do orgulho } & \text { e do } \\
\text { empenho } & \text { exercido } & \text { pelos } \\
\text { indivíduos } & \text { em favor } & \text { dessa } \\
\text { unidade. } & & \end{array}$ & $\begin{array}{l}\text { "O orgulho pela organização está embotado para alguns e é } \\
\text { sempre presente nos antigos que fizeram carreira dentro das } \\
\text { unidades." }\end{array}$ \\
\hline $\begin{array}{l}\text { Gestão Estratégica } \\
\text { de Pessoas }\end{array}$ & $\begin{array}{l}\text { Percepção da adoção de novas } \\
\text { práticas de gestão, de modo a } \\
\text { facilitar as ações de } \\
\text { desenvolvimento e resolução } \\
\text { de conflitos nessa unidade. }\end{array}$ & $\begin{array}{l}\text { "A decisão unificada da corporação nas práticas de gestão de } \\
\text { pessoas em nossas unidades remotas não podem funcionar } \\
\text { bem, pois essas unidades têm suas peculiaridades que precisam } \\
\text { ser tratadas como tal." }\end{array}$ \\
\hline $\begin{array}{l}\text { Cultura } \\
\text { Organizacional }\end{array}$ & $\begin{array}{l}\text { Percepção do conhecimento } \\
\text { que os indivíduos têm, acerca } \\
\text { da visão, filosofia de atuação, } \\
\text { missão e valores dessa unida- } \\
\text { de remota. }\end{array}$ & $\begin{array}{l}\text { "Os funcionários antigos e comprometidos têm feito o esforço } \\
\text { de repassar o que eles têm e o que os faz acreditar na unidade } \\
\text { para os novos." }\end{array}$ \\
\hline &,$c$ & nos dad \\
\hline
\end{tabular}


Os projetos da Fundação, em Monte Dourado, buscam, no engajamento da comunidade, a construção de um sentimento participativo em prol da solução de problemas coletivos. A natureza do trabalho dessa Fundação é, por si só, tido como uma especificidade dentre outras inerentes à estrutura remota. Tal especificidade conta com a essência da natureza das pessoas que se engajam com a missão da Fundação.

No campo educacional o Projeto Reciclando na Escola, uma iniciativa do Grupo Orsa, um conglomerado empresarial de capital $100 \%$ brasileiro, no qual suas principais organizações são a Orsa Celulose, Papel e Embalagens; a Fundação Orsa; a Jari Celulose; e a Orsa Florestal. Esse projeto conta com a colaboração de cerca de 122 mil alunos provenientes de 187 escolas de 17 cidades onde atuam as organizações do Grupo Orsa (a Orsa Celulose, a Jari Celulose e a Fundação Orsa).

Tal iniciativa visa incentivar a educação e a preservação do meio-ambiente, por meio da conscientização de professores, crianças e adolescentes sobre a importância da coleta seletiva de lixo. Modelo de conscientização com responsabilidade, o projeto converte materiais recicláveis em pontos que Valem prêmios. O trabalho começa com a realização de oficinas e palestras nas escolas. Voluntários do Grupo Orsa apresentam os benefícios da reciclagem e salientam a importância da separação correta dos diferentes materiais recicláveis.

O projeto já contribuiu para minimizar o impacto do lixo no meio-ambiente e pode ser considerado como tarefa para todos, de acordo com os dados da pesquisa. A participação e o comprometimento efetivo das indústrias operantes na região constituem uma sólida parceria que garante bons resultados para todos. Elas podem 'apadrinhar' as escolas, destinando todo o lixo reciclável, já separado por seus colaboradores, para suas 'afilhadas'. Essa iniciativa garante o crédito de pontos para as escolas e a conquista de prêmios. Muito mais que um projeto de reciclagem, ele é considerado como uma atitude cidadã.

No campo da saúde, considerando que muitas doenças podem ser evitadas com hábitos saudáveis e alguns cuidados com higiene, a Fundação Orsa cuida de informar à comunidade escolar como evitar diversos tipos dessas doenças. Para tanto, são desenvolvidas oficinas educativas sobre saúde bucal, tabagismo, doenças sexualmente transmissíveis, saneamento básico, correção postural e nutrição, com distribuição de materiais educativos como cartilhas e folders explicativos. 
Colaboradores da Fundação fazem demonstrações de práticas de atividades físicas que podem prevenir problemas de postura, como utilização de bicicleta ergométrica e esteira. Essas atividades contam com o apoio da Jari Celulose, FUNVALE - Fundação Vale do Jari, CADAM S.A., Agrominas, Colégio Positivo, Escola Municipal de Monte Dourado, Clube Jariloca e do comércio local.

No campo educacional-cultural, desde 2004, as ações do projeto Escola de Música no Jarí, idealizado pelo RH e Voluntariado do Grupo Orsa promovem a extensão do ensino musical aos moradores de Monte Dourado, como forma de incentivar o desenvolvimento cultural e promover a inclusão social de crianças, jovens e adultos. Isso é evidenciado por meio da educação musical, difusão da linguagem musical e realização de cursos livres de instrumentos musicais, tais como flauta doce, teclado, violão, dentre outros, além do estímulo à formação e aperfeiçoamento de canto.

O Projeto Escola de Música no Jari firmou um convênio entre Fundação Orsa e Fundação Carlos Gomes, essa última situada em Belém, para o apoio em relação a material didático, instrutores, além de doação dos instrumentos.

A Escola de Música, também, firmou um convênio com a Escola Municipal de Monte Dourado. Desde 2006, a unidade Jari voltou a contribuir para a aquisição dos instrumentos e, atualmente, o Conselho de Voluntariado Corporativo assumiu a coordenação desse projeto. Um fator inovador dessa ação social é a existência de oficinas, nas quais também há a participação de voluntários que desenvolvem trabalhos direcionados às artes plásticas, teatro e dança.

Saliente-se que os dados da pesquisa nessa unidade, mostram chefias e colegas de todas as áreas e/ou da mesma área estimulando: feedbacks, debates, cooperação, valorização do trabalho, reconhecimento pela capacidade de desenvolvimento, confiabilidade e colaboração. Nesse ponto dá-se o cruzamento dos aspectos ligados a comportamento, comprometimento, gestão de pessoas e cultura organizacional, detalhados no quadro $n^{\circ} .24$.

Foram registradas diferenças e semelhanças entre as unidades desse caso. Elas encontram-se condensadas na ilustração $n^{0} 04$. 
ILUSTRAÇÃO No. 04

DIFERENÇAS E SEMELHANÇAS ENTRE UNIDADES CASO 4. 3. GRUPO ORSA

\begin{tabular}{|c|c|c|}
\hline $\begin{array}{l}\text { Jarí Celulose } \\
\text { Incentivos financeiros; } \\
\text { Visão diferenciada de obtenção do } \\
\text { comprometimento; } \\
\text { Retenção de talentos por tempo limitado; } \\
\text { Rotatividade dos gestores; } \\
\text { Vínculo com a Faculdade de Medicina da } \\
\text { Universidade Federal do Pará para } \\
\text { atendimento à comunidade. }\end{array}$ & $\begin{array}{l}\text { Orsa Florestal } \\
\text { Natureza do trabalho; } \\
\text { Alta rotatividade por causa da qualificação } \\
\text { necessária. }\end{array}$ & $\begin{array}{l}\text { Fundação Orsa } \\
\text { Instituição sem fins lucrativos; } \\
\text { Mantida com } 1 \% \text { do faturamento da Jarí } \\
\text { Celulose; } \\
\text { Natureza do trabalho. }\end{array}$ \\
\hline \multicolumn{3}{|c|}{$\begin{array}{l}\text { Preservação Ambiental; } \\
\text { Alguns gestores na corporação em São Paulo; } \\
\text { Residência subsidiada na Vila. }\end{array}$} \\
\hline
\end{tabular}

Fonte: a autora, com base nos dados da pesquisa.

As questões corporativas não podem ser repassadas sem adequação às peculiaridades dessas três unidades, sob pena de colocar em risco a favorabilidade dos resultados a serem obtidos com suas ações.

A estrutura remota, isolada e confinada exige atenção às peculiaridades da região. As semelhanças mostram os traços que unem as pessoas, em todas essas unidades e em torno do mesmo propósito: reter talentos em todas elas, contribuindo com a empresa e com a região, por intermédio do desenpenho do papel social da empresa.

As diferenças denotam os aspectos ligados a comportamento, comprometimento, gestão de pessoas e cultura organizacional, todos eles em interação para a consecução desse propósito nesse caso 4.3 .

\section{4. Caso Mineração Caraíba S/A}

A Mineração Caraíba S/A fica localiada na Fazenda Caraíba, s/no em Pilar - Jaguarari. Jaguarari é um município serrano, no semi-árido do Nordeste, fundado em 1926 no Estado da Bahia, distante da Capital $506 \mathrm{~km}$ e entre Senhor do Bonfim, a $120 \mathrm{~km}$ e Juazeiro, também a 120 km. Seu negócio é o de bens minerais. Sua missão é "prospectar, produzir, transformar e 
comercializar bens minerais." Sua visão é "empreender projetos na área de bens minerais que garantam a perenidade da empresa." Sua política integrada tem "foco na melhoria contínua de bens minerais para a satisfação das necessidades dos clientes, dos acionistas, dos colaboradores e da sociedade."

O projeto minero metalúrgico, vinculado à Caraíba Metais, unidade metalúrgica localizada no Polo Petroqúimico de Camaçari, Bahia é de 1974, com minas a céu aberto e subterrânea. O início das atividades de mineração em Pilar data de 1979. No ano de 1988, deu-se a separação da unidade metalúrgica, face à privatização da Caraíba Metais, passando a mina a ser uma empresa de mineração.

Entre 2005 e 2006 ocorreu a mudança estratégica da empresa. Até o final de 2005, o foco era o da finalização das atividades de mineração, com prazo até 2007. Em 2006, o foco passou a ser o da perenização da empresa.

\section{4. 1 Unidade: Pilar - Jaguarari - Mina de Cobre}

A Mineração Caraíba S/A é produtora de cobre e está situada na bacia do rio São Francisco.

Pilar surgiu na década de 70, com o objetivo de alojar os funcionários da Mineração, trazendo uma perspectiva diferenciada de vida para a região.

Pilar é uma unidade antiga, isolada e confinada, cuja extração de cobre se dá em mina a céu aberto. Seu acesso dá-se por vôos até Juazeiro e por estrada asfaltada, quer saindo de Senhor do Bonfim, quer de Juazeiro.

Ela foi instalada no centro da caatinga, trazendo a água do São Francisco através de uma adutora de $86 \mathrm{~km}$ de extensão, além de infra-estrutura de tratamento de água e esgoto completo, ruas asfaltadas e planejadas, educação, sistema de saúde diferenciado, residências padronizadas, hospital e clubes de lazer.

Todo esse planejamento visava a trazer aos funcionários, atrativos das cidades às quais eles estavam acostumados, de forma que suas famílias pudessem dispor de serviços condizentes com os que dispunham antes de migrar para o alto sertão e habituar-se à nova moradia, favorecendo a retenção dos talentos. 
O quadro $\mathrm{n}^{\circ}$. 28 apresenta o resultado da análise de conteúdo das dezessete entrevistas realizadas nessa unidade.

\begin{tabular}{|c|c|c|c|}
\hline \multicolumn{4}{|c|}{$\begin{array}{l}\text { QUADRO No }{ }^{\circ} 28 \\
\text { RESULTADO DA ANÁLISE DE CONTEÚDO UNIDADE PILAR JAGUARARI }\end{array}$} \\
\hline \multirow{2}{*}{$\begin{array}{l}\text { Unidade de Codificação } \\
\text { Palavras-tema }\end{array}$} & \multirow{2}{*}{ Palavras-chave ou Frases-chave } & \multicolumn{2}{|c|}{ Contagem } \\
\hline & & Presença & Ausência \\
\hline 1. Feedback & $\begin{array}{l}\text { Estímulo; } \\
\text { Evidência. }\end{array}$ & $\begin{array}{l}11 \\
17\end{array}$ & 06 \\
\hline 2. Interações & Integrantes dos diversos escalões. & 15 & 02 \\
\hline 3. Abertura & $\begin{array}{l}\text { Encorajamento para debates; } \\
\text { Ocorrência de debates. }\end{array}$ & $\begin{array}{l}14 \\
17\end{array}$ & $\begin{array}{c}03 \\
-\end{array}$ \\
\hline 4. Comunicações interpessoais & Ocorrência entre as áreas. & 13 & 04 \\
\hline 5. Emoções & Expressão. & 09 & 08 \\
\hline 6. Pensar, sentir e agir & Evidência de interface. & 11 & 06 \\
\hline 7. Tomada de decisão & Ocorrência de em grupo. & 12 & 05 \\
\hline 8. Comportamento intergrupal & Favorecendo o trabalho em equipe. & 14 & 03 \\
\hline 9. Participação & Estímulo à atitude de participação do empregado. & 15 & 02 \\
\hline 10. Envolvimento & $\begin{array}{l}\text { Estímulo à atitude de envolvimento do empregado } \\
\text { com os objetivos organizacionais. }\end{array}$ & 15 & 02 \\
\hline 11. Comprometimento & $\begin{array}{l}\text { Estímulo à atitude de comprometimento } \\
\text { (identificação) do empregado com os objetivos } \\
\text { organizacionais. }\end{array}$ & 16 & 01 \\
\hline 12. Expectativas & $\begin{array}{l}\text { Possibilidade de o empregado comunicar } \\
\text { expectativas em relação à unidade; } \\
\text { Ocorrência de comunicação das expectativas da } \\
\text { unidade em relação ao empregado. }\end{array}$ & $\begin{array}{l}11 \\
09\end{array}$ & 06 \\
\hline 13. Responsabilidades & $\begin{array}{l}\text { Estímulo para o empregado assumir responsabili- } \\
\text { dades sobre suas ações. }\end{array}$ & 13 & 04 \\
\hline 14. Engajamento & $\begin{array}{l}\text { Estímulo ao engajamento das pessoas aos objetivos } \\
\text { e metas organizacionais. }\end{array}$ & 17 & - \\
\hline 15. Características da unidade & $\begin{array}{l}\text { Estimulando as pessoas a despenderem esforços } \\
\text { para nela permanecerem. }\end{array}$ & 16 & 01 \\
\hline 16. Cooperação & $\begin{array}{l}\text { Estímulo à atitude de cooperação; } \\
\text { Evidência da cooperação. }\end{array}$ & $\begin{array}{l}14 \\
17\end{array}$ & $\begin{array}{c}03 \\
-\end{array}$ \\
\hline 17. Valorização & $\begin{array}{l}\text { Evidência da valorização de opiniões e descobertas } \\
\text { em relação à maneira de se obter resultados; } \\
\text { Evidência da valorização do trabalho. }\end{array}$ & 15 & $\begin{array}{l}02 \\
- \\
\end{array}$ \\
\hline 18. Aprendizagem/reaprendizagem & $\begin{array}{l}\text { Reconhecimento da necessidade de aprendiza- } \\
\text { gem/reaprendizagem em relação ao trabalho. }\end{array}$ & 14 & 03 \\
\hline 19. Desenvolvimento & $\begin{array}{l}\text { Demonstração do estímulo ao desenvolvimento } \\
\text { pessoal e profissional na própria organização. }\end{array}$ & 17 & - \\
\hline 20. Incentivos & $\begin{array}{l}\text { Disponibilização de incentivos vinculados a } \\
\text { resultados obtidos pela equipe. }\end{array}$ & 17 & - \\
\hline 21. Reconhecimento & $\begin{array}{l}\text { As pessoas são capazes de: desenvolvimento, } \\
\text { confiança e colaboração. }\end{array}$ & 17 & - \\
\hline $\begin{array}{l}\text { 22. Características organizacionais } \\
\text { da unidade }\end{array}$ & $\begin{array}{l}\text { Atrair e reter pessoas de alto potencial e } \\
\text { qualificação para o trabalho. }\end{array}$ & 12 & 05 \\
\hline $\begin{array}{l}\text { 23. Criação de condições trabalho na } \\
\text { unidade }\end{array}$ & $\begin{array}{l}\text { Favoráveis à manutenção da motivação individual } \\
\text { para o trabalho; } \\
\text { Favoráveis à mobilização dos grupos em torno das } \\
\text { metas organizacionais }\end{array}$ & $\begin{array}{l}10 \\
15\end{array}$ & 07 \\
\hline $\begin{array}{l}\text { 24. Estrutura organizacional da } \\
\text { unidade }\end{array}$ & $\begin{array}{l}\text { Valorizando somente o que a liderança deter-mina; } \\
\text { Valorizando a iniciativa individual; } \\
\text { Valorizando o poder concentrado na liderança; } \\
\text { Valorizando a responsabilidade compartilhada. }\end{array}$ & $\begin{array}{l}07 \\
13 \\
08 \\
11\end{array}$ & $\begin{array}{l}10 \\
04 \\
09 \\
06\end{array}$ \\
\hline 25. Comunicação & $\begin{array}{l}\text { Acerca do que é esperado do desempenho das } \\
\text { pessoas; } \\
\text { Dos acontecimentos críticos que marcam a história } \\
\text { da unidade; }\end{array}$ & 08 & 09 \\
\hline
\end{tabular}




\begin{tabular}{|l|l|c|c|}
\hline & $\begin{array}{l}\text { Ocupação da unidade em saber como está sendo } \\
\text { percebido o seu processo de comunicação formal e } \\
\text { informal. }\end{array}$ & 07 & 10 \\
\hline $\begin{array}{c}\text { Unidade de Codificação } \\
\text { Palavras-tema }\end{array}$ & \multicolumn{1}{|c|}{ Palavras-chave ou Frases-chave } & \multicolumn{2}{|c|}{ Contagem } \\
\cline { 2 - 4 } & Presença & Ausência \\
\hline 26. Missão organizacional & $\begin{array}{l}\text { Ocupação da unidade em saber como está sendo } \\
\text { compreendida sua missão. }\end{array}$ & 10 & 07 \\
\hline 27. Valores & $\begin{array}{l}\text { Demonstração dos valores pelos quais se rege a } \\
\text { unidade; } \\
\text { Comunicação e/ou constatação, pelos empregados, } \\
\text { da coerência entre os valores e o sistema de gestão } \\
\text { da unidade. }\end{array}$ & 12 & 06 \\
\hline 28. Políticas & $\begin{array}{l}\text { Criação das condições de adaptação de políticas } \\
\text { integradas de recursos humanos à realidade da } \\
\text { organização e ao seu contexto de atuação em } \\
\text { unidade remota. }\end{array}$ & 09 & 08 \\
\hline \multicolumn{2}{|l|}{ Fonte: a autora, com base nos dados da pesquisa. } \\
\hline
\end{tabular}

As unidades de codificação 1 a 8 dizem respeito às palavras-tema contidas nos aspectos do comportamento organizacional. A contagem de presenças totalitárias nas unidades de codificação 1 (palavra-chave 2) e 3 (frase-chave 2), seguida de presenças expressivas nas unidades 2, 3 (frase-chave 1), 4 e 8 e substanciais nas unidades de codificação 1 (palavrachave1), 6 e 7, mostra uma visão favorável dos entrevistados em relação aos aspectos ligados ao comportamento organizacional. As ausências contidas nas palavras-tema da unidade de codificação 5, quase eqüitativas com as presenças, não são desprezíveis e podem ser conduzidas a um diálogo investigativo das razões.

As unidades de codificação 9 a 16 estão voltadas para as palavras-tema contidas nos aspectos do comprometimento organizacional. A contagem de presenças é totalitária nas unidades de codificação 14, e 16 (frase-chave 2); expressiva, quase totalitária, nas unidades de codificação 9,10,11, 15 e 16 (frase-chave 1); substancial, nas unidades de codificação 12 (frase-chave 1) e13, o que denota favorabilidade, na percepção dos entrevistados, com relação a esses aspectos voltados para o comprometimento. A unidade de codificação 12 (frase-chave 2), mostra que as ausências são significativas e necessitam de investigação das razões que estão nelas embutidas.

As unidades de codificação 17 a 23 referem-se às palavras-tema contidas nos aspectos de gestão estratégica de pessoas. As presenças são totalizadoras nas unidades de codificação 17 (frase-chave 2), 19, 20 e 21; quase totalizadoras nas 17 (frase-chave 1) e 23 (frase-chave 2); substanciais nas 18 e 22. As ausências observadas nas unidades de codificação 22 e 23 (frasechave 1) denotam necessidade de investigação para a compreensão das razões. 
As unidades de codificação 24 a 28 estão no bojo das palavras-tema contidas nos aspectos da cultura organizacional. Note-se, nesse quadro, na unidade de codificação 24 - estrutura organizacional da unidade, com a frase-chave "valorizando somente o que a liderança determina", que a incidência de ausências pode denotar uma estrutura não centralizada e com flexibilidade. Isso pode ser reforçado com as presenças expressivas nas frases-chave "valorizando a iniciativa individual" e "valorizando a responsabilidade compartilhada", sem desprezar o provável significado das ausências registradas nessa última. A frase-chave "valorizando o poder concentrado na liderança", não obstante a incidência ser um pouco maior nas ausências, a divisão apresentada entre presenças e ausências dá o alerta para a investigação do tema por ela evidenciado.

$\mathrm{Na}$ unidade de codificação 25 (frases-chave 1 e 3), encontram-se ausências substanciais, podendo denotar necessidade de investigação das prováveis causas, na medida em que elas podem indicar percepções desfavoráveis, na visão dos entrevistados, no que tange aos aspectos concernentes à cultura dessa unidade remota. Ainda na unidade de codificação 25 , a frase-chave 2 apresenta presença totalitária. Nas unidades de codificação 26, 27 e 28, apesar das presenças serem superiores, as ausências apresentam-se significativas para serem investigados os aspectos da cultura a elas relacionados.

O quadro $\mathrm{n}^{\circ} 29$ apresenta o resultado da análise de conteúdo aplicadado ao escopo da pesquisa nessa unidade remota e contribui para aprofundar a compreensão do que foi mostrado no quadro $n^{\circ} 28$.

\begin{tabular}{|c|l|l|}
\hline \multicolumn{2}{|c|}{ RESULTADO DA ANÁLISE DE CONTEUDO NPLICADO AO ESCOPO DA PESQUISA } \\
UNIDADE PILAR JAGUARARI
\end{tabular}




\begin{tabular}{|c|c|c|}
\hline & & $\begin{array}{l}\text { "Existe sinergia dos empregados para gerar contribuição. Cada pessoa } \\
\text { tem dado de si em prol da unidade. Os mais antigos juntam-se aos } \\
\text { mais recentes e, dessa junção nasce um bom fruto. A estrutura } \\
\text { favorece bastante essa junção." }\end{array}$ \\
\hline $\begin{array}{l}\text { Categorias de } \\
\text { Análise }\end{array}$ & Temas Significativos & Unidade de Codificação \\
\hline $\begin{array}{c}\text { Comprometimento } \\
\text { Organizacional }\end{array}$ & $\begin{array}{l}\text { Percepção do orgulho e } \\
\text { do empenho exercido } \\
\text { pelos indivíduos em } \\
\text { favor dessa unidade. }\end{array}$ & $\begin{array}{l}\text { "O orgulho começa a ser demonstrado outra vez, após dezoito meses } \\
\text { de reestruturação. O empenho das pessoas é perene e mesmo quando } \\
\text { houve desconfiança e velado descontentamento, esse empenho não foi } \\
\text { afetado." } \\
\text { "As pessoas têm orgulho e muitas delas não caem na tentação do } \\
\text { mercado. A complexidade da operação faz da unidade uma grande } \\
\text { escola." } \\
\text { "Muitos que saíram na fase de ameaça de fechamento retomaram e } \\
\text { expressam o seu orgulho o reengajamento e o empenho continua } \\
\text { inalterado. A unidade tem um elenco de pessoas com mais de } 20 \text { anos } \\
\text { de empresa e, o retorno de muitas delas comprova o empenho, o } \\
\text { orgulho e o comprometimento com a nova fase da empresa." } \\
\text { "Não temos a cultura do feedback, o que é ruim, mas o orgulho e o } \\
\text { empenho estão acima disso. É preciso disseminá-la com feedback } \\
\text { positivamente válido e útil." } \\
\text { "A equipe como um todo demonstra um vínculo afetivo com a história } \\
\text { da unidade. Os resultados obtidos pela empresa atestam o orgulho, o } \\
\text { engajamento, o empenho e a forte dedicação por trás deles." }\end{array}$ \\
\hline $\begin{array}{c}\text { Gestão Estratégica } \\
\text { de Pessoas }\end{array}$ & $\begin{array}{l}\text { Percepção da adoção de } \\
\text { novas práticas de } \\
\text { gestão, de modo a } \\
\text { facilitar as ações de } \\
\text { desenvolvimento e } \\
\text { resolução de conflitos } \\
\text { nessa unidade. }\end{array}$ & $\begin{array}{l}\text { "Tudo o que existia de favorável antes do processo de reestruturação } \\
\text { passou a ser incorporado às novas práticas de gestão de pessoas." } \\
\text { "Considero que as ações de desenvolvimento e resolução de conflitos } \\
\text { estão sendo reconstruídas após a retomada da organização. Cuidamos } \\
\text { para que as ações de gestão de pessoas sejam prioritariamente } \\
\text { empreendidas em conjunto, não obstante o tempo para a retomada } \\
\text { careça ser observado sempre." } \\
\text { "Temos um plano de saúde e odontológico exemplar. Seguro de vida } \\
\text { extensivo a esposa e filhos até a universidade." } \\
\text { "Os estímulos para pós-graduação são atrativos para facilitar a } \\
\text { retenção dos talentos. Equipamentos para a conexão com o 'mundo' } \\
\text { são disponibilizados pela unidade." } \\
\text { "A participação nos lucros é uma pratica adotada que vem } \\
\text { estimulando as pessoas. As equipes de melhoria contínua e segurança } \\
\text { enfatizam as ações de gestão de pessoas." }\end{array}$ \\
\hline $\begin{array}{c}\text { Cultura } \\
\text { Organizacional }\end{array}$ & $\begin{array}{l}\text { Percepção do conhe- } \\
\text { cimento que os indi- } \\
\text { víduos têm, acerca da } \\
\text { visão, filosofia de } \\
\text { atuação, missão e } \\
\text { valores dessa unidade } \\
\text { remota. }\end{array}$ & $\begin{array}{l}\text { "Merecem destaque os trabalhos de difusão e aprofundamento da } \\
\text { importância de dois valores cruciais para a sobrevivência da unidade: } \\
\text { segurança e meio-ambiente. A transparência aumentará com a } \\
\text { aproximação propiciada pelos aspectos comportamentais." } \\
\text { "Em termos de visão, filosofia de atuação, missão e valores da } \\
\text { unidade o momento presente é dedicado à retirada do que está mais } \\
\text { nas paredes para que a ação, em todas as áreas, seja de demonstração } \\
\text { de assimilação mais profunda." } \\
\text { "Cuidados para que o que está escrito seja praticado se conso-lidam } \\
\text { diariamente. O código de ética mostra a observância dos valores que } \\
\text { cons-tam do sistema de gestão." } \\
\text { "O compromisso assumido lembra a todos, os valores existentes na } \\
\text { unidade. O comprometimento com os aspectos ligados a } \\
\text { responsabilidade social, segurança e meio-ambiente é de } \\
\text { responsabilidade de todos." }\end{array}$ \\
\hline
\end{tabular}


Em meados de 1995, a Mineração Caraíba S/A constituiu o PRODAEP - Projeto de Diversificação da Atividade Econômica de Pilar, com o objetivo precípuo de buscar formas de viabilização de outras atividades produtivas. O PRODAEP articulou-se à Mineração e ao Governo do Estado da Bahia e conseguiu recursos para estruturar e instalar: oficina comunitária de confecções; oficina comunitária de artefatos de couros; espaço cultural do artesanato de Pilar.

Os dados da pesquisa mostram que essa unidade tem a característica de atrair e reter talentos, haja vista a questão dos muitos que retornaram após o período crítico 2005-2006. Alguns gestores são oriundos de muitas mudanças de regiões/empresas e afirmam que vivem um momento propício para apreciar a qualidade de vida que a região da caatinga tem lhes proporcionado. O estímulo para as pessoas dispenderem esforços e manterem-se na unidade é alto e o orgulho de trabalhar nela é comunicado para fora com intensidade. A comunidade também expressa o respeito por essas pessoas. O comprometimento é tido como elevado e as pessoas o expressam em suas ações cotidianas.

Há o reconhecimento financeiro, por parte da unidade, com o programa de participação nos lucros. O foco da contribuição é visto em linha com o retorno financeiro e a estabilidade propiciada na carreira. O retorno recíproco é estimulado, sempre alinhado com qualidade e segurança. A estrutura favorece, pois estimula a transparência, de acordo com os dados das entrevistas.

A diversidade cultural, oriunda da importação da mão-de-obra qualificada das diversificadas regiões do país, pode, também, ser fonte geradora de conflitos e os dados da pesquisa mostram que os gestores estão sabendo dosar as ações de capitalização do potencial dessa diversidade em prol da manutenção das condições favoráveis ao comprometimento na unidade.

É considerada baixíssima a rotatividade da mão-de-obra em toda a unidade. Os gestores são norteados por sua identidade organizacional (missão, visão, crenças, valores e política da qualidade ou de gestão integrada) que, no conjunto, enfatiza o compromisso com todas as partes interessadas: acionistas, força de trabalho, clientes, governos e sociedade, com a cultura da excelência. Tal cultura é disseminada entre os colaboradores, em reuniões com a alta direção e o corpo gerencial, sendo continuamente discutida e avaliada, com base nos valores que 
integram a identidade organizacional. No dia-a-dia, a atuação compartilhada e participativa dos gestores, junto aos colaboradores, funciona como exemplo de determinação e empenho em cultivar, dentro da unidade, as melhores práticas de gestão em busca da excelência.

Os gestores compartilham responsabilidades com suas equipes, estimulando os vários escalões a participarem da tomada de decisões, o que resulta em um ambiente organizacional de cooperação e respeito mútuo. As determinações empresariais são estruturadas e comunicadas por intermédio de fóruns diversos que facilitam a disseminação das informações e o engajamento de todos os colaboradores com as metas estabelecidas no ciclo anual de planejamento estratégico da unidade, iniciativa que tem sido considerada de fundamental importância para as conquistas obtidas pela organização.

A gestão de pessoas é compreendida dentro de uma abordagem holística, envolvendo o profissional como um ser integral, por meio de ações para beneficiá-lo dentro e fora do ambiente de trabalho, na família e na sociedade. A pesquisa de clima, realizada periodicamente, contempla espaço para sugestões que podem ser aproveitadas como oportunidade de melhoria. Na busca dessa melhoria contínua dos processos, produtos e serviços da empresa, a unidade adotou o modelo de gestão participativa, com o envolvimento da diretoria e de todos os empregados. Essa forma de atuação tem sido percebida como fundamental para a manutenção da identidade organizacional e para atingir os resultados esperados, tomando-se por base a cultura de excelência.

Ainda como prática de gestão de pessoas, é mantido um canal aberto e direto entre a alta direção e os colaboradores, com um programa informal, que conta com participação, inclusive de terceiros e estagiários. Nesse programa, a diretoria reúne-se com os colaboradores e responde a perguntas, dá informações sobre os principais acontecimentos e decisões e apresenta os balanços, resultados operacionais e financeiros. Essa interação está refletida nas diversas conquistas obtidas nos últimos anos, com a melhoria contínua da qualidade dos produtos e serviços, bem como nas pesquisas de satisfação realizadas periodicamente.

A unidade estabelece uma estrutura de cargos, cujas habilidades exigidas estão alinhadas com os objetivos da organização. Para preenchimento das vagas existentes, é realizado um processo de seleção, que prioriza os profissionais que já prestam serviços na empresa, como forma de estimular o autodesenvolvimento e a busca pela melhoria contínua da força de trabalho. $\mathrm{O}$ 
desempenho das pessoas é avaliado utilizando-se várias práticas de remuneração e reconhecimento, que estimulam o alcance das metas, a cultura da excelência e o desenvolvimento profissional.

Essas práticas incluem: participação nas metas do programa de sugestão e participação nas metas das equipes de melhoria contínua, gerando uma remuneração variável; acompanhamento do desempenho no dia-a-dia e, mensalmente, através dos itens de verificação e de controle sob a responsabilidade de cada um; rodízio entre os substitutos permitindo identificar os que apresentam as melhores competências para exercício do cargo; fóruns, como seminários internos de resolução de problemas, realizados pelos gestores e seminários de equipes de melhoria contínua, organizados pela força de trabalho.

O plano de treinamento, qualificação e aperfeiçoamento profissional é atualizado anualmente, com base no levantamento das necessidades de competências focadas no alcance das metas estabelecidas pelo planejamento estratégico. Além dos treinamentos previstos no plano anual, que beneficiam também estagiários e prestadores de serviços, a força de trabalho realiza cursos periódicos de reciclagem em segurança, higiene e medicina do trabalho e educação ambiental.

A atenção às questões relativas à saúde, ergonomia e bem-estar é demonstrada com o desenvolvimento de programas para melhoria da qualidade de vida dos colaboradores, familiares e prestadores de serviço. Todos os empregados passam por exames médicos periódicos e são treinados e conscientizados sobre os riscos a que estão expostos em suas atividades, participando de campanhas preventivas, como a de combate à dengue, com mobilização inclusive da comunidade local.

O compromisso com a dimensão socioambiental é mantido pela unidade, incorporado em todos os processos de gestão e envolve desde a alta direção, aos gerentes e colaboradores. Funciona como pólo irradiador de cidadania, desenvolvendo ações e incentivando iniciativas inteligentes de projetos auto-sustentáveis que gerem emprego e renda e promovam a melhoria da qualidade de vida dos colaboradores, prestadores de serviço e da comunidade. $\mathrm{O}$ voluntariado entre a força de trabalho é incentivado por essa unidade, conscientizando-a sobre a importância de uma atuação responsável em relação aos aspectos socio-ambientais e ao desenvolvimento de projetos e ações sociais. Dentro dessa filosofia de voluntariado várias iniciativas foram desenvolvidas com o auxílio de empregados e gestores da unidade, comunidade, parcerias 
com poder público e sociedade civil, Rotary Clube, Centro de Recuperação da Dependência Química Vila Serena e o Grupo de Alcoólicos Anônimos/Al-Anon Caraíba. Tendo em vista o beneficiando da comunidade podem-se destacar: projeto 'dando as mãos à cidadania'; campanha 'jogue limpo com o Pilar'; campanha 'doe sangue, salve vidas'; 'show de talentos'; 'prevenção e recuperação da dependência química'.

Reforce-se que os dados da pesquisa, nessa unidade, mostram chefias e colegas de todas as áreas e/ou da mesma área estimulando: feedbacks, debates, engajamento, cooperação, valorização do trabalho, reconhecimento pela capacidade de desenvolvimento, confiabilidade e colaboração. Nesse ponto dá-se o cruzamento dos aspectos ligados a comportamento, comprometimento, gestão de pessoas e cultura organizacional, detalhados no quadro $\mathrm{n}^{\circ} 28$.

Foram registradas as características específicas dessa unidade, constituinte única desse caso 4.4 e elas encontram-se condensadas na ilustração $n^{\circ} 05$.

\section{ILUSTRAÇÃO №. 05}

\section{CARACTERÍSTICAS ESPECÍFICAS DO CASO 4. 4. MINERAÇÃO CARAÍBA}

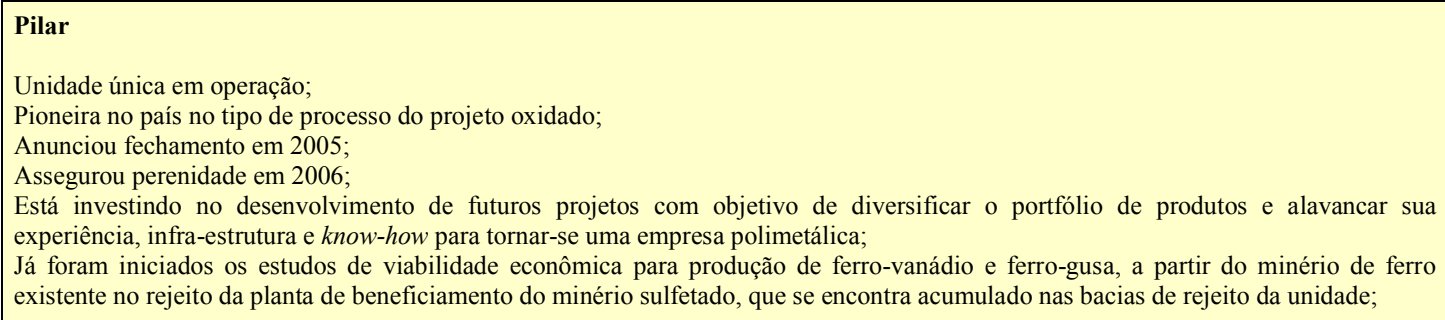

Ficou enfatizado que a existência de uma estrutura hierárquica simplificada facilita a comunicação entre os diversos níveis, possibilitando agilidade na tomada de decisões e o comprometimento de todos os empregados com a cultura da excelência empresarial, disseminada através de seus valores: compromisso com o desenvolvimento profissional, social e satisfação dos colaboradores; a qualidade total e transparência na gestão; a melhoria contínua dos métodos e processos; sobreviver pela competência; respeitar leis, normas, costumes, contratos e decisões de instâncias competentes; garantir condições adequadas de segurança e saúde ocupacional; preservar o meio-ambiente; ser socialmente responsável. 
A unidade vem passando por uma transformação radical, desde a estratégia de assegurar a sua perenidade em 2006. Os indivíduos e os grupos estão em fase de assimilação da transformação, uma vez que o impacto do anúncio de continuidade foi de desconfiança inicial. $\mathrm{O}$ anúncio de fechamento em 2005 já havia sido assimilado e, algumas vantagens já haviam sido internalizadas, com planos de mudança de vida para muitos.

Em 2007, foram iniciados os trabalhos de instalação para a exploração na jazida de ouro na cidade de Nova Xavantina, Estado do Mato Grosso. Ainda nesse mesmo ano foi adquirida a cessão dos direitos minerários da jazida de cobre sulfetado da Mina Boa Esperança, localizada no sul do Estado do Pará, no município de Tucumã, região de Carajás.

Pioneira no país no tipo de processo do projeto oxidado e utilizando o minério proveniente de uma pilha de minério adjacente à planta, que foi retirado no início das operações da mina a céu aberto, a perspectiva é produzir 4,5 toneladas de catodo de cobre por ano, por um período mínimo de cinco anos. As primeiras placas de catodo de cobre foram produzidas no mês de outubro de 2007. Os projetos que vêm sendo desenvolvidos para abertura de novas unidades têm estimulado as pessoas a reiterarem o orgulho de pertencer à organização. O empenho é perceptível na forma integrada de pensar coletiva e transparentemente. Os entrevistados afirmam que todos sabem que podem gerar os resultados esperados e o fazem em colaboração com os outros.

\section{5 Caso Votorantim Metais}

Captar e reter talentos que tenham afinidade com os valores da empresa é o desafio para o contínuo crescimento da Votorantim Metais. Na prática, o Sistema de Desenvolvimento Votorantim assegura que, ocupando ou não funções de liderança, os profissionais saibam qual o caminho, as competências e quais atributos devem desenvolver para evoluir na Votorantim. Essa transparência estimula e orienta a ascensão na carreira, tornando o sistema uma ferramenta de gestão não apenas de líderes, mas de pessoas.

Assim é descrita a política de higiene, segurança, meio-ambiente e qualidade da empresa: "É politica da VM, operar de maneira segura e responsável, respeitanto a saúde das pessoas e o meio-ambiente das comunidades onde atua, fornecendo produtos e serviços que atendam ou 
superem as necessidades dos clientes internos e externos." Seus princípios envolvem: treinar, dar suporte e envolver os funcionários, na busca constante de melhoria de qualidade dos produtos, processos e serviços; prevenir a poluição e os acidentes; cumprir ou superar as exiências legais e de qualidade; deixar claros os papéis e responsabilidades de todos; adotar as melhores práticas de gestão de HSMQ; auditar e planejar melhorias com os resultados. Eles salientam que todas as pessoas têm o dever de entender, promover e apoiar essa política e os próprios princípios.

Preparar jovens profissionais para posições mais desafiantes é parte da estratégia de crescimento da Votorantim Metais. Para isso, a empresa desenvolveu o programa "Desenvolver Jovens Profissionais". Visando o futuro, a iniciativa trabalha com o desenvolvimento de conceitos e habilidades dos profissionais com até 30 anos. O programa "Trainees" busca jovens recém graduados, com interesse nas áreas de atuação da empresa e que se identifiquem com a visão, os valores e a cultura Votorantim.

Com o objetivo de "oxigenar a empresa com jovens talentos", ela mantém o programa "Caminhar", que oferece oportunidades para estagiários de nível superior. Através desse programa, a empresa atrai, desenvolve e retém profissionais com potencial para atender aos desafios e demandas dos negócios. Além do suporte educacional aos jovens participantes do "Caminhar", a Votorantim Metais prepara orientadores de estágio com conhecimento e técnica para a condução do programa. Para participar, o jovem deve ter idade entre 18 e 25 anos, estar cursando os dois últimos anos de um curso de graduação que seja compatível com as exigências das áreas de atuação das unidades.

Desenvolver equipes de alta performance é criar um ambiente de trabalho mais participativo, descentralizar o processo decisório, aumentar a eficiência da comunicação dentro da empresa e desenvolver pessoas com foco no processo, na análise crítica dos resultados e com visão sistêmica. Dessa forma, considera-se que as unidades se tornam mais ágeis e flexíveis.

A Votorantim Metais, alinhada com a política de gestão de pessoas que permeia todas as empresas do Grupo, apóia e colabora com projetos que beneficiem os colaboradores, melhorem o ambiente de trabalho dentro das empresas do Grupo e que ajudem a preservar a história da Votorantim. 


\section{5. 1 Unidade: Votorantim Metais Zinco e Cobalto - Niquelândia}

Essa unidade de negócio tem sua área de mineração instalada em Niquelândia - Goiás, onde ocorrem a extração de minério de níquel laterítico e a produção do carbonato de níquel. Esses produtos abastecem a usina metalúrgica, localizada no bairro de São Miguel Paulista, São Paulo. Nessa unidade são fabricados o níquel eletrolítico e o cobalto.

Em 1735, em busca de riquezas no norte goiano onde foi encontrado ouro de aluvial, foi fundada uma vila que perdurou por anos em grande desenvolvimento e chegou a ser uma das vilas mais desenvolvidas de Goiás. Em 1755 foi fundado o povoado de São José do Tocantins. Em 1833 o povoado passou à categoria de município. Em 1938, o minerador alemão Helmult Brooks, garimpando na região, descobriu enormes jazidas de níquel, que atraiu exploradores do Brasil inteiro, fazendo com que a vila crescesse rapidamente, em população e riqueza. Em homenagem ao minério que lhe deu riqueza e fama, passou a chamar-se Niquelândia.

Atualmente, o município de Niquelândia é o maior de Goiás e possui uma das maiores reservas de níquel do mundo, explorada por duas grandes mineradoras: essa unidade da Votorantin Metaise a Codemim, empresa do Grupo Anglo - América, do Banco Bozzano Simonsen. A unidade Niquelândia é considerada remota, isolada e confinada, com atividade de extração do níquel e cobalto em mina a céu aberto.

O quadro $\mathrm{n}^{\circ} 30$ apresenta o resultado da análise de conteúdo das quinze entrevistas realizadas nessa unidade.

\begin{tabular}{|c|c|c|c|}
\hline \multicolumn{4}{|c|}{$\begin{array}{c}\text { QUADRO No. } 30 \\
\text { RESULTADO DA ANÁLISE DE CONTEÚDO UNIDADE NIQUELÂNDIA }\end{array}$} \\
\hline \multirow{2}{*}{$\begin{array}{l}\text { Unidade de Codificação } \\
\text { Palavras-tema }\end{array}$} & \multirow[t]{2}{*}{ Palavras-chave ou Frases-chave } & \multicolumn{2}{|c|}{ Contagem } \\
\hline & & Presença & Ausência \\
\hline 1. Feedback & $\begin{array}{l}\text { Estímulo; } \\
\text { Evidência. }\end{array}$ & $\begin{array}{l}12 \\
15\end{array}$ & $\begin{array}{c}03 \\
-\end{array}$ \\
\hline 2. Interações & Integrantes dos diversos escalões. & 13 & 02 \\
\hline 3. Abertura & $\begin{array}{l}\text { Encorajamento para debates; } \\
\text { Ocorrência de debates. }\end{array}$ & $\begin{array}{l}14 \\
15\end{array}$ & $\begin{array}{l}01 \\
-\end{array}$ \\
\hline 4. Comunicações interpessoais & Ocorrência entre as áreas. & 11 & 04 \\
\hline 5. Emoções & Expressão. & 08 & 07 \\
\hline 6. Pensar, sentir e agir & Evidência de interface. & 11 & 04 \\
\hline 7. Tomada de decisão & Ocorrência de em grupo. & 14 & 01 \\
\hline 8. Comportamento intergrupal & Favorecendo o trabalho em equipe. & 14 & 01 \\
\hline
\end{tabular}




\begin{tabular}{|c|c|c|c|}
\hline \multirow{2}{*}{$\begin{array}{l}\text { Unidade de Codificação } \\
\text { Palavras-tema }\end{array}$} & \multirow[t]{2}{*}{ Palavras-chave ou Frases-chave } & \multicolumn{2}{|c|}{ Contagem } \\
\hline & & Presença & Ausência \\
\hline 9. Participação & Estímulo à atitude de participação do empregado. & 15 & - \\
\hline 10. Envolvimento & $\begin{array}{l}\text { Estímulo à atitude de envolvimento do empregado } \\
\text { com os objetivos organizacionais. }\end{array}$ & 14 & 01 \\
\hline 11. Comprometimento & $\begin{array}{l}\text { Estímulo à atitude de comprometimento } \\
\text { (identificação) do empregado com os objetivos } \\
\text { organizacionais. }\end{array}$ & 15 & - \\
\hline 12. Expectativas & $\begin{array}{l}\text { Possibilidade de o empregado comunicar } \\
\text { expectativas em relação à unidade; } \\
\text { Ocorrência de comunicação das expectativas da } \\
\text { unidade em relação ao empregado. }\end{array}$ & $\begin{array}{l}13 \\
11\end{array}$ & $\begin{array}{l}02 \\
04\end{array}$ \\
\hline 13. Responsabilidades & $\begin{array}{l}\text { Estímulo para o empregado assumir responsabili- } \\
\text { dades sobre suas ações. }\end{array}$ & 13 & 02 \\
\hline 14. Engajamento & $\begin{array}{l}\text { Estímulo ao engajamento das pessoas aos objetivos } \\
\text { e metas organizacionais. }\end{array}$ & 15 & - \\
\hline 15. Características da unidade & $\begin{array}{l}\text { Estimulando as pessoas a despenderem esforços } \\
\text { para nela permanecerem. }\end{array}$ & 15 & - \\
\hline 16. Cooperação & $\begin{array}{l}\text { Estímulo à atitude de cooperação; } \\
\text { Evidência da cooperação. }\end{array}$ & $\begin{array}{l}15 \\
15\end{array}$ & - \\
\hline 17. Valorização & $\begin{array}{l}\text { Evidência da valorização de opiniões e desco- } \\
\text { bertas em relação à maneira de se obter resultados; } \\
\text { Evidência da valorização do trabalho. }\end{array}$ & 12 & $\begin{array}{l}03 \\
- \\
\end{array}$ \\
\hline 18. Aprendizagem/reaprendizagem & $\begin{array}{l}\text { Reconhecimento da necessidade de aprendiza- } \\
\text { gem/reaprendizagem em relação ao trabalho. }\end{array}$ & 12 & 03 \\
\hline 19. Desenvolvimento & $\begin{array}{l}\text { Demonstração do estímulo ao desenvolvimento } \\
\text { pessoal e profissional na própria organização. }\end{array}$ & 14 & 01 \\
\hline 20. Incentivos & $\begin{array}{l}\text { Disponibilização de incentivos vinculados a } \\
\text { resultados obtidos pela equipe. }\end{array}$ & 14 & 01 \\
\hline 21. Reconhecimento & $\begin{array}{l}\text { As pessoas são capazes de: desenvolvimento, } \\
\text { confiança e colaboração. }\end{array}$ & 15 & - \\
\hline $\begin{array}{l}\text { 22. Características rganizacionais da } \\
\text { unidade }\end{array}$ & $\begin{array}{l}\text { Atrair e reter pessoas de alto potencial e qualifi- } \\
\text { cação para o trabalho. }\end{array}$ & 11 & 04 \\
\hline $\begin{array}{l}\text { 23. Criação de condições de trabalho } \\
\text { na unidade }\end{array}$ & $\begin{array}{l}\text { Favoráveis à manutenção da motivação individual } \\
\text { para o trabalho; } \\
\text { Favoráveis à mobilização dos grupos em torno das } \\
\text { metas organizacionais. }\end{array}$ & 08 & $\begin{array}{l}07 \\
01\end{array}$ \\
\hline $\begin{array}{l}\text { 24. Estrutura organizacional da } \\
\text { unidade }\end{array}$ & $\begin{array}{l}\text { Valorizando somente o que a liderança determina; } \\
\text { Valorizando a iniciativa individual; } \\
\text { Valorizando o poder concentrado na liderança; } \\
\text { Valorizando a responsabilidade compartilhada. }\end{array}$ & $\begin{array}{l}- \\
11 \\
01 \\
15\end{array}$ & $\begin{array}{l}15 \\
04 \\
14 \\
-\end{array}$ \\
\hline 25. Comunicação & $\begin{array}{l}\text { Acerca do que é esperado do desempenho das } \\
\text { pessoas; } \\
\text { Dos acontecimentos críticos que marcam a história } \\
\text { da unidade; } \\
\text { Ocupação da unidade em saber como está sendo } \\
\text { percebido o seu processo de comunicação formal e } \\
\text { informal. }\end{array}$ & $\begin{array}{l}14 \\
15 \\
11\end{array}$ & $\begin{array}{l}01 \\
- \\
04\end{array}$ \\
\hline 26. Missão organizacional & $\begin{array}{l}\text { Ocupação da unidade em saber como está sendo } \\
\text { compreendida sua missão. }\end{array}$ & 13 & 02 \\
\hline 27. Valores & $\begin{array}{l}\text { Demonstração dos valores pelos quais se rege a } \\
\text { unidade; } \\
\text { Comunicação e/ou constatação, pelos empregados, } \\
\text { da coerência entre os valores e o sistema de gestão } \\
\text { da unidade. }\end{array}$ & $\begin{array}{l}14 \\
13\end{array}$ & $\begin{array}{l}01 \\
02\end{array}$ \\
\hline 28. Políticas & $\begin{array}{l}\text { Criação das condições de adaptação de políticas } \\
\text { integradas de recursos humanos à realidade da } \\
\text { organização e ao seu contexto de atuação nessa } \\
\text { unidade remota. }\end{array}$ & 12 & 03 \\
\hline
\end{tabular}


As unidades de codificação 1 a 8 dizem respeito às palavras-tema contidas nos aspectos do comportamento organizacional. A contagem de presenças totalitárias nas unidades de codificação 1 (palavra-chave 2) e 3 (frase-chave 2), seguida de presenças expressivas nas unidades 2, 3 (frasechave 1), 7 e 8 e substanciais nas unidades de codificação 1 (palavra-chave1), 4 e 6, mostra uma visão favorável dos entrevistados em relação aos aspectos ligados ao comportamento organizacional. As ausências contidas na unidade de codificação 5 são substanciais e podem ser conduzidas a um diálogo investigativo das razões. As contidas nas unidades de codificação 4 e 6 não podem ser ignoradas.

As unidades de codificação 9 a 16 estão voltadas para as palavras-tema contidas nos aspectos do comprometimento organizacional. A contagem de presenças é totalitária nas unidades de codificação 9, 11, 14, 15 e 16 (frases-chave 1 e 2); expressiva nas unidades de codificação 10 , 12 (frase-chave 1) e 13; substancial, na unidade de codificação 12 (frase-chave 2), o que denota favorabilidade, na percepção dos entrevistados, com relação a esses aspectos voltados para o comprometimento. As ausências verificadas na unidade de codificação 12(frase-chave 2), não devem ser desprezadas.

As unidades de codificação 17 a 23 referem-se às palavras-tema contidas nos aspectos de gestão estratégica de pessoas. As presenças são totalizadoras nas unidades de codificação 17 (frasechave 2) e 21; quase totalizadoras nas 19, 20 e 23 (frase-chave 2); substanciais nas 18 e 22 . As ausências observadas nas unidades de codificação 22 e, principalmente, 23 (frase-chave 1) não podem ser desprezadas, denotando necessidade de investigação para a compreensão das razões.

As unidades de codificação 24 a 28 estão no bojo das palavras-tema contidas nos aspectos da cultura organizacional. Registre-se, nesse quadro, a ausência encontrada na unidade de codificação 24 - estrutura organizacional da unidade, com as frases-chave "valorizando somente o que a liderança determina" e "valorizando o poder concentrado na liderança", as quais apresentam o aspecto positivo da falta de centralização nas lideranças, o que é reforçado pelas presenças totalitárias e significativas das frases-chave "valorizando a responsabilidade compartilhada" e "valorizando a iniciativa individual", muito emboras as ausências registradas nessa última já mereçam consideração para serem observadas.

As unidades de codificação 25 (frase-chave 3) e 28 apresentam ausências que já podem suscitar investigação das prováveis causas dessas ausências, indicadoras de atenção a esses 
aspectos concernentes à cultura organizacional dessa unidade remota. O quadro $\mathrm{n}^{\mathbf{0}} \quad 31$ apresenta o resultado da análise de conteúdo aplicadado ao escopo da pesquisa nessa unidade remota e contribui para aprofundar a compreensão do que foi mostrado no quadro $\mathrm{n}^{\circ} 30$.

\begin{tabular}{|c|c|c|}
\hline \multicolumn{3}{|c|}{$\begin{array}{l}\text { QUADRO No.31 } \\
\text { RESULTADO DA ANÁLISE DE CONTEÚDO APLICADO AO ESCOPO DA PESQUISA } \\
\text { UNIDADE NIQUELÂNDIA }\end{array}$} \\
\hline $\begin{array}{l}\text { Categorias de } \\
\text { Análise }\end{array}$ & Temas Significativos & Unidade de Codificação \\
\hline $\begin{array}{l}\text { Comportamento } \\
\text { Organizacional }\end{array}$ & $\begin{array}{l}\text { Percepção da con- } \\
\text { tribuição dos indiví- } \\
\text { duos, dos grupos e da } \\
\text { estrutura. }\end{array}$ & $\begin{array}{l}\text { "A estrutura contribui com a forma de comando, com a arrumação } \\
\text { física, com a aproximação gerada pela convivência em vila." } \\
\text { "As pessoas contribuem em grupos com as orientações da estrutura. } \\
\text { Voluntariamente e por intermédio das ferramentas de gestão as } \\
\text { pessoas participam e contribuem com os resultados." } \\
\text { "As pessoas que aqui contribuem muito fortemente com a dedicação } \\
\text { diária. A estrutura contribui com os recursos e com o clima para que a } \\
\text { pressão diária do trabalho seja amenizada." } \\
\text { "O objetivo comum encarrega as pessoas para empenharem-se na } \\
\text { obtenção dos resultados. A unidade busca contribuir com a integração } \\
\text { para o estímulo dos colaboradores de todas as áreas e isso é extensivo } \\
\text { às famílias." } \\
\text { "A estrutura contribui para que as pessoas contribuam, por sua forma } \\
\text { de integrar políticas e práticas compatíveis com o incremento da } \\
\text { confiança e da abertura contínua para debates." }\end{array}$ \\
\hline $\begin{array}{c}\text { Comprometimento } \\
\text { Organizacional }\end{array}$ & $\begin{array}{l}\text { Percepção do orgulho e } \\
\text { do empenho exercido } \\
\text { pelos indivíduos em } \\
\text { favor dessa unidade. }\end{array}$ & $\begin{array}{l}\text { "O orgulho e o empenho caminham juntos. As pessoas querem fazer o } \\
\text { melhor que podem." } \\
\text { "Quem está aqui faz tudo para não sair. Quem está fora faz tudo para } \\
\text { entrar." } \\
\text { "A dedicação em ensinar e aprender é forte. Empenho e orgulho estão } \\
\text { entrelaçados aqui." } \\
\text { "As pessoas respeitam a empresa e têm consciência da importância } \\
\text { dessa unidade para a região." } \\
\text { "A qualidade dos recursos oferecidos aumenta o empenho e o orgulho } \\
\text { de fazer parte da unidade." } \\
\text { "O orgulho é traduzido pelas comemorações com os sucessos e } \\
\text { solidariedade com as dificuldades." } \\
\text { "A estrutura reconhece o comprometimento do grupo e não o } \\
\text { individual, muito emboa as pessoas sejam comprometidas com os } \\
\text { resultados e dêem o melhor de si mesmas." } \\
\text { "A dedicação é muito grande. O nível de engajamento e } \\
\text { comprometimento das pessoas com a unidade é muito alto." } \\
\text { "O objetivo comum encarrega as pessoas para o empenho na obtenção } \\
\text { dos resultados." } \\
\text { "Uma geradora de orgulho, engajamento e comprometimento é a } \\
\text { participação das pessoas, iniciando como aprendiz e galgando } \\
\text { gradativamente os espaços na unidade." }\end{array}$ \\
\hline
\end{tabular}




\begin{tabular}{|c|c|c|}
\hline $\begin{array}{l}\text { Categorias de } \\
\text { Análise }\end{array}$ & Temas Significativos & Unidade de Codificação \\
\hline $\begin{array}{c}\text { Gestão Estratégica } \\
\text { de Pessoas }\end{array}$ & $\begin{array}{l}\text { Percepção da adoção de } \\
\text { novas práticas de } \\
\text { gestão, de modo a } \\
\text { facilitar as ações de } \\
\text { desenvolvimento e } \\
\text { resolução de conflitos } \\
\text { nessa unidade remota. }\end{array}$ & $\begin{array}{l}\text { "A distância dificulta a aquisição de bons profissionais no nível } \\
\text { estratégico. A retenção de pessoas é dificultada apenas pela } \\
\text { localização." } \\
\text { "O ouvir mais disponível favorece o processo de contribuição } \\
\text { contínua." } \\
\text { "A escola precisa inserir disciplinas de gestão de pessoas nos } \\
\text { currículos de engenharia. Aprendemos com muito sofrimento na } \\
\text { prática." } \\
\text { "A redução dos níveis hierárquicos promoveu maior aproxima-ção } \\
\text { entre todos os integrantes da unidade." } \\
\text { "A universidade não me ensinou a ser gestor. Aprendi aqui, com a } \\
\text { gestão, om o cenário." } \\
\text { "As pessoas são o diferencial da unidade. Comprometidas com os } \\
\text { resultados, elas dão o melhor de si." } \\
\text { "A residência na vila aproxima as pessoas. Entretando, os sentimentos } \\
\text { não são expressos, ainda que sejam estimulados, pois as pessoas } \\
\text { afirmam que não querem misturar o profissional com o pessoal." }\end{array}$ \\
\hline $\begin{array}{c}\text { Cultura } \\
\text { Organizacional }\end{array}$ & $\begin{array}{l}\text { Percepção do conheci- } \\
\text { mento que os indiví- } \\
\text { duos têm acerca da } \\
\text { visão, filosofia de } \\
\text { atuação, missão e } \\
\text { valores dessa unidade } \\
\text { remota. }\end{array}$ & $\begin{array}{l}\text { "As metas somente serão efetivas com segurança e trabalho de equipe. } \\
\text { Segurança é um valor prioritário." } \\
\text { "Nas reuniões diárias os valores (solidez, ética, respeito, } \\
\text { empreendedorismo e união) são repassados, assim como a missão, a } \\
\text { visão e a filosofia de atuação." } \\
\text { "A essência (visão, filosofia de atuação, missão e valores) é } \\
\text { perceptivelmente conhecida. As palavras, como registadas, estão } \\
\text { expostas no livrinho de bolso que todos têm atualizado." } \\
\text { "Segurança é um valor implícito para todos. Treansparência é forte na } \\
\text { unidade. Responsabilidade socio-ambiental ainda precisa de reforço } \\
\text { contínuo." }\end{array}$ \\
\hline
\end{tabular}

Os dados da pesquisa mostram que a estrutura dessa unidade contribui com o mapa estratégico e indicadores claros para o gerenciamento das pessoas. Por sua vez, essas pessoas dão suas contribuições com a união para o alcance dos objetivos comuns. A diversidade cultural, oriunda das mais variadas regiões do país, é também responsável pela riqueza na ação de gerar contribuição.

Uma parte substancial do nível operacional é regional, outra, a partir do nível técnico, ou saiu da região para estudar e retornou ou veio de outras regiões do país. Os desafios oferecidos, quando aceitos, promovem crescimento rápido. $\mathrm{O}$ empenho caminha conjuntamente com o orgulho no cumprimento das metas da unidade. O orgulho é tido como grande e evidenciado pelo trabalho bem feito. 
Os entrevistados consideram-no uma conquista representativa, em função da responsabilidade assumida. Os nativos são considerados os que mais o demonstram, tanto dentro da unidade quanto na comunidade. O nível operacional é o que absorve o maior contingente desses nativos.

Os que chegam de fora mostram empenho na ação de atingir os resultados propostos. Os que participam da unidade, desde a época que chegam para os estágios do período de férias, demonstram orgulho, automotivação e vontade de enfrentar os desafios. A qualidade dos recursos oferecidos aumenta o empenho e o orgulho de fazer parte dessa unidade, de acordo com os resultados apresentados.

Engajar, renovar e realizar são partes dos três papéis das lideranças. O empenho das pessoas para gerar resultados positivos torna-se elevado quando os gestores uilizam-se desse tripé. A retenção de pessoas nessa unidade é considerada difícil apenas pela sua localização e isso fica comfirmado pela perda de talentos para outras unidades do Grupo Votorantim.

Os valores reportados pelos gestores como fundamentais para as suas práticas são liberdade e confiança.

Dentre as práticas de gestão de pessoas utilizadas na unidade, destacam-se: participação nos lucros; parceria com a prefeitura de Niquelândia; reunião de três pontas (supervisores, equipes e DHO - Desenvolvimento Humano e Organizacional); diálogo aberto; projeto amigos do futuro (municipal, estadual e privado); projetos de sustentabilidade (agropecuária e agricultura); formação de mão de-obra futura; escolaridade incentivada para pais e filhos; feedback de avaliação de desempenho; conheça nossa fábrica (para a comunidade); reunião com os vizinhos (para a comunidade); sistema de liderança; espaço aberto - café com o gerente geral; fale fácil; equipes de melhoria contínua; facilitadores de área; gestão do meioambiente; pesquisa de clima, na qual a unidade encontra-se entre as primeiras colocadas.

Enfatize-se que os dados da pesquisa, nessa unidade, mostram chefias e colegas de todas as áreas e/ou da mesma área estimulado: feedbacks, debates, engajamento, cooperação, valorização do trabalho, reconhecimento pela capacidade de desenvolvimento, confiabilidade e colaboração. Nesse ponto dá-se o cruzamento dos aspectos ligados a comportamento, comprometimento, gestão de pessoas e cultura organizacional, detalhados no quadro $\mathrm{n}^{\mathrm{o}} 30$. 


\section{5. 2 Unidade: Votorantim Metais Zinco - Três Marias}

Três Marias é conhecida como "Doce Mar de Minas", por ser uma cidade tranqüila e agradável, margeada pelo rio São Francisco e banhada pelas águas límpidas do grande lago que tem o nome da cidade. É privilegiada pelas belezas do cerrado, cujo símbolo maior são as veredas do sertão. A cidade assegura as condições para o turismo rural e para atividades de ecoturismo, por possuir inúmeras nascentes, riachos e grande número de cachoeiras.

O grande lago tem ilimitado potencial para abrigar esportes náuticos e pesca esportiva ou amadora, além de oferecer belas praias e ilhas paradisíacas. O rio São Francisco é considerado e respeitado, face sua importância e grandiosidade para a região. O apoio irrestrito da Prefeitura Municipal faz crescer cada vez mais o mercado de turismo e as atividades dele decorrentes.

Inaugurada em 1962 e administrada pela CEMIG, a Usina Hidrelétrica de Três Marias é considerada de grande importância para o Brasil. Sua potência instalada de 396 MW fornece $80 \%$ da energia consumida na região norte de Minas. Com a construção da barragem, o rio São Francisco passou a ser navegável em qualquer época do ano. Com a instalação da usina, o governo federal assegurou o aproveitamento de inúmeras oportunidades de investimento na agricultura, pecuária, mineração, comércio e no setor de serviços.

No município, cuja produção tradicional é de algodão, feijão e cereais, além da criação de bovinos e suínos tem, na área industrial, a produção de energia elétrica pela Usina e a do zinco pela Votorantim Metais. O quadro $\mathrm{n}^{\mathrm{o}} 32$ apresenta o resultado da análise de conteúdo das quinze entrevistas realizadas nessa unidade.

\begin{tabular}{|c|c|c|c|}
\hline \multicolumn{4}{|c|}{$\begin{array}{l}\text { QUADRO Nó. } 32 \\
\text { RESULTADO DA ANÁLISE DE CONTEÚDO UNIDADE TRÊS MARIAS }\end{array}$} \\
\hline \multirow{2}{*}{$\begin{array}{l}\text { Unidade de Codificação } \\
\text { Palavras-tema }\end{array}$} & \multirow[t]{2}{*}{ Palavras-chave ou Frases-chave } & \multicolumn{2}{|c|}{ Contagem } \\
\hline & & Presença & Ausência \\
\hline 1. Feedback & $\begin{array}{l}\text { Estímulo; } \\
\text { Evidência. }\end{array}$ & $\begin{array}{l}11 \\
15\end{array}$ & $\begin{array}{c}04 \\
-\end{array}$ \\
\hline 2. Interações & Integrantes dos diversos escalões. & 11 & 04 \\
\hline 3. Abertura & $\begin{array}{l}\text { Encorajamento para debates; } \\
\text { Ocorrência de debates. }\end{array}$ & $\begin{array}{l}12 \\
15\end{array}$ & $\begin{array}{c}03 \\
-\end{array}$ \\
\hline 4. Comunicações interpessoais & Ocorrência entre as áreas. & 11 & 04 \\
\hline 5. Emoções & Expressão. & 06 & 09 \\
\hline 6. Pensar, sentir e agir & Evidência de interface. & 07 & 08 \\
\hline 7. Tomada de decisão & Ocorrência de em grupo. & 13 & 02 \\
\hline 8. Comportamento intergrupal & Favorecendo o trabalho em equipe. & 14 & 01 \\
\hline 9. Participação & Estímulo à atitude de participação do empregado. & 13 & 02 \\
\hline
\end{tabular}




\begin{tabular}{|c|c|c|c|}
\hline \multirow{2}{*}{$\begin{array}{l}\text { Unidade de Codificação } \\
\text { Palavras-tema }\end{array}$} & \multirow[t]{2}{*}{ Palavras-chave ou Frases-chave } & \multicolumn{2}{|c|}{ Contagem } \\
\hline & & Presença & Ausência \\
\hline 10. Envolvimento & $\begin{array}{l}\text { Estímulo à atitude de envolvimento do empregado } \\
\text { com os objetivos organizacionais. }\end{array}$ & 10 & 05 \\
\hline 11. Comprometimento & $\begin{array}{l}\text { Estímulo à atitude de comprometimento } \\
\text { (identificação) do empregado com os objetivos } \\
\text { organizacionais. }\end{array}$ & 13 & 02 \\
\hline 12. Expectativas & $\begin{array}{l}\text { Possibilidade de o empregado comunicar expecta- } \\
\text { tivas em relação à unidade; } \\
\text { Ocorrência de comunicação das expectativas da } \\
\text { unidade em relação ao empregado. }\end{array}$ & 09 & $\begin{array}{l}06 \\
04\end{array}$ \\
\hline 13. Responsabilidades & $\begin{array}{l}\text { Estímulo para o empregado assumir responsabili- } \\
\text { dades sobre suas ações. }\end{array}$ & 13 & 02 \\
\hline 14. Engajamento & $\begin{array}{l}\text { Estímulo para o engajamento das pessoas aos } \\
\text { objetivos e metas organizacionais. }\end{array}$ & 15 & - \\
\hline 15. Características da unidade & $\begin{array}{l}\text { Estimulando as pessoas a despenderem esforços } \\
\text { para nela permanecerem. }\end{array}$ & 09 & 06 \\
\hline 16. Cooperação & $\begin{array}{l}\text { Estímulo à atitude de cooperação; } \\
\text { Evidência da cooperação. }\end{array}$ & $\begin{array}{l}13 \\
15\end{array}$ & $\begin{array}{c}02 \\
-\end{array}$ \\
\hline 17. Valorização & $\begin{array}{l}\text { Evidência da valorização de opiniões e desco- } \\
\text { bertas em relação à maneira de se obter resultados; } \\
\text { Evidência da valorização do trabalho. }\end{array}$ & 13 & $\begin{array}{l}02 \\
- \\
\end{array}$ \\
\hline 18. Aprendizagem/reaprendizagem & $\begin{array}{l}\text { Reconhecimento da necessidade de aprendiza- } \\
\text { gem/reaprendizagem em relação ao trabalho. }\end{array}$ & 13 & 02 \\
\hline 19. Desenvolvimento & $\begin{array}{l}\text { Demonstração do estímulo ao desenvolvimento } \\
\text { pessoal e profissional na própria organização. }\end{array}$ & 13 & 02 \\
\hline 20. Incentivos & $\begin{array}{l}\text { Disponibilização de incentivos vinculados a resul- } \\
\text { tados obtidos pela equipe. }\end{array}$ & 10 & 05 \\
\hline 21. Reconhecimento & $\begin{array}{l}\text { As pessoas são capazes de: desenvolvimento, } \\
\text { confiança e colaboração. }\end{array}$ & 15 & - \\
\hline $\begin{array}{l}\text { 22. Características organizacionais } \\
\text { da unidade }\end{array}$ & $\begin{array}{l}\text { Atrair e reter pessoas de alto potencial e quali- } \\
\text { ficação para o trabalho. }\end{array}$ & 07 & 08 \\
\hline 23. Criação de condições & $\begin{array}{l}\text { Favoráveis à manutenção da motivação individual } \\
\text { para o trabalho; } \\
\text { Favoráveis à mobilização dos grupos em torno das } \\
\text { metas organizacionais. }\end{array}$ & $\begin{array}{l}04 \\
12\end{array}$ & $\begin{array}{l}11 \\
03\end{array}$ \\
\hline $\begin{array}{l}\text { 24. Estrutura organizacional da } \\
\text { unidade }\end{array}$ & $\begin{array}{l}\text { Valorizando somente o que a liderança determina; } \\
\text { Valorizando a iniciativa individual; } \\
\text { Valorizando o poder concentrado na liderança; } \\
\text { Valorizando a responsabilidade compartilhada. }\end{array}$ & $\begin{array}{l}03 \\
13 \\
03 \\
13\end{array}$ & $\begin{array}{l}12 \\
02 \\
12 \\
02\end{array}$ \\
\hline 25. Comunicação & $\begin{array}{l}\text { Acerca do que é esperado do desempenho das } \\
\text { pessoas; } \\
\text { Dos acontecimentos críticos que marcam a história } \\
\text { da organização/unidade; } \\
\text { Ocupação da unidade em saber como está sendo } \\
\text { percebido o seu processo de comunicação formal e } \\
\text { informal. }\end{array}$ & $\begin{array}{l}11 \\
14 \\
08\end{array}$ & $\begin{array}{l}04 \\
01 \\
07\end{array}$ \\
\hline 26. Missão organizacional & $\begin{array}{l}\text { Ocupação da unidade em saber como está sendo } \\
\text { compreendida sua missão. }\end{array}$ & 14 & 01 \\
\hline 27. Valores & $\begin{array}{l}\text { Demonstração dos valores pelos quais se rege a } \\
\text { organização/unidade; } \\
\text { Comunicação e/ou constatação, pelos empregados, } \\
\text { da coerência entre os valores e o sistema de gestão } \\
\text { da unidade. }\end{array}$ & $\begin{array}{l}13 \\
10\end{array}$ & $\begin{array}{l}02 \\
05\end{array}$ \\
\hline 28. Políticas & $\begin{array}{l}\text { Criação das condições de adaptação de políticas } \\
\text { integradas de recursos humanos à realidade da } \\
\text { organização e ao seu contexto de atuação nessa } \\
\text { unidade. }\end{array}$ & 07 & 08 \\
\hline
\end{tabular}

As unidades de codificação 1 a 8 dizem respeito às palavras-tema contidas nos aspectos do comportamento organizacional. A contagem de presenças totalitárias nas unidades de codificação 
1 (palavra-chave 2), 3 (frase-chave 2), seguida de presenças expressivas nas unidades 3 (frasechave 1), 7 e 8 e substanciais nas unidades de codificação 2 e 4, mostra uma visão favorável dos entrevistados em relação aos aspectos ligados ao comportamento organizacional.

Ainda nessas unidades 2 e 4, as ausências não podem ser ignoradas. Porém, as ausências contidas nas palavras-tema das unidades de codificação 5 e 6 são expressivas e induzem à condução de um diálogo investigativo das razões uma vez que já denotam percepção desfavorável acerca dos aspectos comportamentais nelas emutidos.

As unidades de codificação 9 a 16 estão voltadas para as palavras-tema contidas nos aspectos do comprometimento organizacional. A contagem de presenças é totalitária nas unidades de codificação 14, e 16 (frase-chave 2); expressiva nas unidades de codificação 9,11, 13 e 16 (frase-chave 1); substancial na unidade de codificação 12 (frase-chave 1), o que denota favorabilidade, na percepção dos entrevistados, com relação a esses aspectos voltados para o comprometimento. No entanto, as ausências detectadas nas unidades de codificação 10, 12 (em ambas as frases-chave, principalmente na 1) e 15 mostram que as ausências são significativas e necessitam de investigação das razões que estão nelas embutidas.

As unidades de codificação 17 a 23 referem-se às palavras-tema contidas nos aspectos de gestão estratégica de pessoas. As presenças são totalizadoras nas unidades de codificação 17 (frase-chave 2) e 21; expressivas nas 17 (frase-chave 1), 18, 19 e 23 (frase-chave 2); significativas, na 20. As ausências observadas nas unidades de codificação 22 e 23 (frasechave 1) denotam necessidade de investigação para a compreensão das razões, uma vez que se aprentam com expressividade, seguidas de significativas aus $\sim$ encias na unidade de codificação 20 .

As unidades de codificação 24 a 28 estão no bojo das palavras-tema contidas nos aspectos da cultura organizacional. Registre-se, nesse quadro, a ausência encontrada na unidade de codificação 24 - estrutura organizacional da unidade, com as frases-chave "valorizando somente o que a liderança determina" e "valorizando o poder concentrado na liderança" mostra o aspecto positivo da falta de centralização, o que é reforçado pela presença significativa das frases-chave "valorizando a responsabilidade compartilhada" e "valorizando a iniciativa individual". 
As unidades de codificação 25 (frase-chave 3), 27 (frase-chave 2) e 28 apresentam ausências substanciais, podendo denotar necessidade de investigação das prováveis causas dessas ausências, na medida em que elas podem indicar percepções desfavoráveis, na visão dos entrevistados, no que tange aos aspectos concernentes à cultura dessa unidade remota.

O quadro $\mathrm{n}^{\circ} 33$ apresenta o resultado da análise de conteúdo aplicadado ao escopo da pesquisa nessa unidade remota e contribui para aprofundar a compreensão do que foi mostrado no quadro $n^{0} 32$.

\begin{tabular}{|c|c|c|}
\hline \multicolumn{3}{|c|}{$\begin{array}{l}\text { QUADRO No. } 33 \\
\text { RESULTADO DA ANÁLISE DE CONTEÚDO APLICADO AO ESCOPO DA PESQUISA } \\
\text { UNIDADE TRÊS MARIAS }\end{array}$} \\
\hline $\begin{array}{l}\text { Categorias de } \\
\text { Análise }\end{array}$ & Temas Significativos & Unidade de Codificação \\
\hline $\begin{array}{c}\text { Comportamento } \\
\text { Organizacional }\end{array}$ & $\begin{array}{l}\text { Percepção da con- } \\
\text { tribuição dos indiví- } \\
\text { duos, dos grupos e da } \\
\text { estrutura. }\end{array}$ & $\begin{array}{l}\text { "A estrutura tem um trabalho desafiante de trazer as pessoas para a } \\
\text { unidade." } \\
\text { "A expressão de sentimentos não é comum. Há um preconceito que } \\
\text { precisa ser quebrado entre as áreas, em prol da contribui-ção } \\
\text { potecialmente embotada." } \\
\text { "Ha disposição das áreas para enxergar a interdependência. Falta a } \\
\text { demonstração da ação." } \\
\text { "A contribuição das pessoas é ler e interpretar os procedimen-tos para } \\
\text { gerar resultados mais qualificados." } \\
\text { "A forma de gestão da estrutura da unidade contribui com a liberdade } \\
\text { e com o foco voltado para a obtenção dos resultados." } \\
\text { "As pessoas contribuem usando o que a estrutura oferece para gerar, } \\
\text { com a sua dedicação, comprometimento com os resultados. Elas } \\
\text { entram com alta motivação." } \\
\text { "Há interdependência entre as áreas." } \\
\text { "A estrutura muito enxuta dificulta e as atividades rotineiras ocuoam } \\
\text { muito tempo." } \\
\text { "As unidades remotas precisam investir em pessoas da terra pra } \\
\text { resolver os problemas de retenção." }\end{array}$ \\
\hline $\begin{array}{c}\text { Comprometimento } \\
\text { Organizacional }\end{array}$ & $\begin{array}{l}\text { Percepção do orgulho e } \\
\text { do empenho exercido } \\
\text { pelos indivíduos em } \\
\text { favor dessa unidade. }\end{array}$ & $\begin{array}{l}\text { "Há um trabalho constante de pertença. Os empregados demonstram o } \\
\text { seu orgulho. A unidade estimula que eles tenham voz." } \\
\text { "Quem é da terra demonstra orgulho por contribuir com a cidade. } \\
\text { Quem é de fora tem um tempo determinado e contribuem com o } \\
\text { orgulho socio-econômico-ambiental." } \\
\text { "O orgulho é demonstrado pela explicitação da importância que a } \\
\text { empresa tem para a região e para o país." } \\
\text { "O clima evidencia o orgulho, quer com as pessoas da região ou com } \\
\text { as que vêm de fora e interagem." } \\
\text { "O empenho e o orgulho estão juntos e com simplicidade. É uma }\end{array}$ \\
\hline
\end{tabular}




\begin{tabular}{|c|c|c|}
\hline & & $\begin{array}{l}\text { busca diária mantê-los assim." } \\
\text { "O orgulho de pertencer à unidade estimula as pessoas a se } \\
\text { empenharem. Há criação de uma forte identidade." }\end{array}$ \\
\hline $\begin{array}{l}\text { Categorias de } \\
\text { Análise }\end{array}$ & Temas Significativos & Unidade de Codificação \\
\hline $\begin{array}{c}\text { Gestão Estratégica } \\
\text { de Pessoas }\end{array}$ & $\begin{array}{l}\text { Percepção da adoção de } \\
\text { novas práticas de } \\
\text { gestão, de modo a } \\
\text { facilitar as ações de } \\
\text { desenvolvimento } \\
\text { resolução de conflitos } \\
\text { nessa unidade. }\end{array}$ & $\begin{array}{l}\text { "A rotatividade no nível operacional é baixa. No nível estratégico é } \\
\text { alta, uma vez que as pessoas vêm de fora e fazem o remanejamento } \\
\text { por unidade." } \\
\text { "Os encontros mensal e trimestral por turno de trabalho com o gerente } \\
\text { geral não fazem parte de uma estrutura de faz-de-conta. As pessoas } \\
\text { podem colocar-se e o fazem!" } \\
\text { "A verificação da mudança na vida das pessoas dentro da unidade é a } \\
\text { maior recompensa que o gestor recebe." } \\
\text { "Ouvir as pessoas é a prática mais impressionante na unidade." } \\
\text { "As práticas de gestão ajudam a tirar proveito das melhores } \\
\text { experiências de todos." } \\
\text { "Todas as práticas garantem melhores resultados para a unidade." } \\
\text { "A dinâmica do trabalho não permite tempo coltado para as pessoas. } \\
\text { A razão precisa estar em equilíbrio com a emoção, mas é preciso fazer } \\
\text { tal equilíbrio. Primeiro as pessoas para que o trabalho venha como } \\
\text { conseqüência." }\end{array}$ \\
\hline $\begin{array}{c}\text { Cultura } \\
\text { Organizacional }\end{array}$ & $\begin{array}{l}\text { Percepção do conhe- } \\
\text { cimento que os } \\
\text { indivíduos têm acerca } \\
\text { da visão, filosofia de } \\
\text { atuação, missão e } \\
\text { valores dessa unidade } \\
\text { remota. }\end{array}$ & $\begin{array}{l}\text { "Alguns valores estão fortemente internalizados em todos os níveis. É } \\
\text { um processo educativo, entretanto." } \\
\text { "O Mapa Estratégico é o orientador básico." } \\
\text { "O uniforme é igual em todos os níveis e isso aproxima as pessoas." } \\
\text { "O Mapa Estratégico facilitou a compreensão do que todos da unidade } \\
\text { precisam fazer para atingir os objetivos." }\end{array}$ \\
\hline & & om base nos dados da pesquisa. \\
\hline
\end{tabular}

Os entrevistados consideram que a contribuição dessa unidade, para a comunidade, reside na qualificação da mão-de-obra e educação da população, como parte da política de responsabilidade social. Os líderes têm o orgulho de reduzir o passivo ambiental, contribuir para a elevação da educação das pessoas e mudar as condições da comunidade.

O foco nos valores é mais importante do que a capacidade cognitiva. Os valores melhoram o orgulho das pessoas. Os operários demonstram orgulho por terem oportunidade de incrementar a capacidade de empregabilidade, por meio da educação. Mudanças técnica e educacional dão retorno demorado, mas consistente. $\mathrm{O}$ reconhecimento de todos pela obtenção dos resultados é o maior impulsionador.

As pessoas e a estrutura contribuem com o conhecimento que cada um tem de sua área, com a resolução colaborativa dos problemas da unidade, com grupo eclético de discussão de todas as 
áreas. A competência valorizada estimula a contribuição. Há variedade de intercâmbio entre as áreas e, muitas vezes, entre unidades. Espontaneamente, as pessoas dão de si, o que é necessário para solucionar e/ou aprimorar o desenvolvimento das atividades, em prol dos objetivos e metas da unidade.

As práticas de gestão utilizadas na unidade são: programa educacional dos empregados em prol do desenvolvimento no longo prazo; subsídio para a comunidade estudar; programa de segurança no trabalho; cronograma de automação de atividades, sem prejuízo do clima, em prol da vida preservada; exercício de comunicação com a comunidade, principalmente pescadores do rio São Francisco; reunião mensal - rede de cooperação com os stakeholders; reunião de três pontas, envolvendo supervisores, empregados e DHO; reunião de turno com os operários, em meses alternados; estágios de férias universitárias; EMC; projetos compartilhados; reuniões matriciais; reuniões de gestão de custos com pessoas de todas as áreas; pós-graduação específica dentro da unidade; diálogos diários; reuniões de três pontas; programa de relacionamento com a comunidade para elevação da escolaridade, independente de ser funcionário; voluntariado para orientação com adolescentes gestantes; café com o gerente geral, grupos mesclados; monitoria ambiental; programa departicipação nos lucros; programas de remuneração variável e premiação.

Utilizando-se do Mapa Estratégico da unidade para facilitar o aprendizado acerca da visão, filosofia de atuação, missão e valores da unidade, a reciclagem contíniua é adotada nas reuniões diárias e em estudos de caso com grupos de 4 a 5 integrantes. A regra de ouro é ensinada como a autonomia de parar o processo produtivo, qualquer que seja o nível ocupado, em prol da vida. Qualquer funcionário pode ser desligado se descumprir as regras de segurança.

Os atrativos para as pessoas são: o nome da empresa caracterizando estabilidade, a solidariedade, a qualidade de vida proporcionada pela cidade, a responsabilidade social e ambiental. A abertura gerada para o relacionamento franco forma uma das bases de contribuição que ligam as pessoas e a estrutura. A outra é a transparência como valor e como estratégia da unidade. Atrair talentos é de extrema facilidade. Retê-los é muito difícil, não obstante o nome da empresa, a remuneração variável, os programas de incentivo às idéias, os desafios, as perspectivas de crescimento, benefícios, moradia e qualidade de vida. Os desafios são constantes na unidade e há poucas opções na cidade e na comunidade. A dificuldade de adaptação é o principal problema de retenção. 
A ênfase nas pessoas é a base para o incremento do comprometimento. A seriedade e a responsabilidade da empresa propiciam as condições para obtenção dos resultados da unidade. Orgulho e empenho caminham juntos e há o reconhecimento pelas oportunidades pessoais e profissionais, dizem os dados da pesquisa. Para os não nativos, é o emblema que orgulha, qualquer que seja a unidade da empresa. Eles demonstram o seu orgulho com o comprometimento constante em fazer com que os resultados sejam alcançados com qualidade. O empenho, a dedicação e o desprendimento para fazer o melhor em sua gestão, são pontos constantes de observação positiva. Para os nativos é mostrar para a cidade que usam o emblema e o orgulho é o de pertencer à unidade. Eles demonstram o empenho em fazer bem feito o seu trabalho.

Registre-se que os dados da pesquisa, nessa unidade, mostram chefias e colegas de todas as áreas e/ou da mesma área estimulado: feedbacks, debates, engajamento, cooperação, valorização do trabalho, reconhecimento pela capacidade de desenvolvimento, confiabilidade e colaboração. Nesse ponto dá-se o cruzamento dos aspectos ligados a comportamento, comprometimento, gestão de pessoas e cultura organizacional, detalhados no quadro $\mathrm{n}^{\mathrm{o}} 32$.

Foram registradas diferenças e semelhanças entre as duas unidades constituintes desse caso e elas encontram-se condensadas na ilustração $\mathrm{n}^{\circ} 06$.

\section{ILUSTRAÇ̃̃O No. 06 \\ DIFERENÇAS E SEMELHANÇAS ENTRE UNIDADES CASO 4. 5. V. METAIS}

\begin{tabular}{|c|c|}
\hline $\begin{array}{l}\text { Niquelândia } \\
\text { Nessa unidade são fabricados o níquel eletrolítico e o cobalto; } \\
\text { Por intermédio das equipes de melhoria contínua é obtida a } \\
\text { participação de } 90 \% \text { das pessoas, contemplando segurança, } \\
\text { saúde, meio-ambiente e qualidade; } \\
\text { A unidade está em busca de adicional por trabalho em local } \\
\text { remoto. }\end{array}$ & $\begin{array}{l}\text { Três Marias } \\
\text { Metas específicas por áreas: remuneração variável dividida por } \\
\text { Grupo Salarial - GS: Até } 30 \text { PPR; } \\
\text { Metas pessoais estabelecidas pelo gerente geral Acima de30 RV } \\
\text { ou Bônus; } \\
\text { INOVE é uma remuneração à parte, fica na área de gestão; }\end{array}$ \\
\hline \multicolumn{2}{|l|}{ SEMELHANÇAS } \\
\hline \multicolumn{2}{|c|}{$\begin{array}{l}\text { Para os que são contratados de fora e moram na vila há o subsídio de casa, água, luz, clube e academia; } \\
\text { Para os que são contratados de fora e não moram na vila, há ajuda de custo para moradia fora da vila; } \\
\text { Mapa Estratégico; } \\
\text { Captação, qualificação e retenção de talentos; } \\
\text { Educação formal; } \\
\text { Valores segurança, saúde, meio-ambiente, qualidade de vida e responsabilidade socioambiental; } \\
\text { Parcerias. }\end{array}$} \\
\hline
\end{tabular}


As semelhanças mostram os traços que unem as pessoas, em ambas as unidades e em torno do mesmo propósito: reter talentos em todas elas, contribuindo com a empresa e com a região, por intermédio do desenpenho do papel social da empresa. A qualidade das comunicações precisa ser observada em todas duas. Os dados da pesquisa mostram que o advento do e-mail ocasionou muitas perdas na comunicação direta. Há, em ambas, a clareza de que o feedback contribui para o alinhamento mais rápido entre as pessoas. As diferenças denotam os aspectos ligados a comportamento, comprometimento, gestão de pessoas e cultura organizacional, todos eles em interação para a consecução desse propósito nesse caso 4.5.

No que tange aos aspectos de segurança, saúde, meio-ambiente e qualidade, a Votorantim Metais mantém uma busca constante por melhorias nos processos industriais e nos indicadores de desempenho ambiental, que dêem maiores condições de preservação do meioambiente. Entre as ações realizadas estão a revegetação de áreas mineradas, reciclagem, recirculação de águas industriais, atividades de educação ambiental, monitoramento da água, do solo e do ar, e também dos efluentes líquidos, sólidos e gasosos.

Em sintonia com a postura socialmente responsável, mantida por todas as empresas do Grupo, a Votorantim Metais tem sua estratégia de crescimento baseada no conceito de sustentabilidade e de respeito a seus parceiros, colaboradores, fornecedores e, em especial, às comunidades na qual está inserida e ao meio-ambiente. Mantém diversos programas sociais destinados ao aumento da qualidade de vida dos colaboradores e daqueles que, de alguma maneira, estão ligados a ela. Entre eles, os programas de: incentivo à educação continuada; capacitação de portadores de deficiência para o mercado de trabalho; educação e formação profissional de jovens das comunidades; apoio à cultura, de geração de renda; incentivo ao voluntariado; proteção ao meio ambiente.

A Votorantim Metais ocupa a posição de maior produtora de níquel eletrolítico na América latina e parte dessa história a empresa vem construindo município de Niquelândia, desde 1957. Em 2007, a empresa investiu em melhorias e expansão da unidade Niquelândia e na construção de uma nova fábrica nesse município, destinada à produção de ferro-níquel, bem como na instalação de uma caldeira a coque nessa unidade. Essa nova caldeira visa a permitir a flexibilização da matriz energética, ao substituir o uso de óleo combustível. 
A Votorantim Metais é considerada a maior produtora de zinco das Américas e está entre as dez maiores produtoras mundiais. Hoje, a empresa mantém, no Brasil, duas minas nas cidades de Vazante e Paracatu (Morro Agudo) e duas unidades industriais, uma em Três Marias e outra em Juiz de Fora. A unidade Três Marias iniciou sua trajetória em 1956 com a criação da Companhia Mineira de Metais (CMM), em Três Marias, território mineiro.

Ainda em Juiz de Fora, será construída a primeira fábrica de Polimetálicos do Brasil, que otimizará a recuperação de metais existentes nas matérias primas como cobre, prata e índio e permitirá prover soluções ambientalmente adequadas para pó de aciaria elétrica e baterias automotivas.

\section{6. Caso PETROBRAS}

Fundada no dia 3 de outubro de 1953, pelo então presidente Getúlio Vargas, com a edição da Lei $\mathrm{n}^{\mathrm{o}}$ 2004, a criação da Petrobras foi formalizada, com o objetivo de exercer o monopólio estatal do petróleo no Brasil em nome da União. A Petróleo Brasileiro S/A - PETROBRAS iniciou suas atividades com o acervo recebido do antigo Conselho Nacional do Petróleo (CNP), que manteve sua função fiscalizadora sobre o setor.

As operações de exploração e produção de petróleo, bem como as demais atividades ligadas ao setor de petróleo, gás natural e derivados, à exceção da distribuição atacadista e da revenda no varejo pelos postos de abastecimento, foram monopólio conduzido pela Petrobras de 1954 a 1997. Durante esse período a Petrobras tornou-se líder em comercialização de derivados no País.

Depois de exercer por mais de 40 anos o monopólio estatal do petróleo no Brasil, a Petrobras passou a competir com outras empresas estrangeiras em 1997, quando o presidente Fernando Henrique Cardoso sancionou a Lei $\mathrm{n}^{\circ} 9.478$ que pôs fim a esse monopólio e abriu as atividades da indústria petrolífera à iniciativa privada. A partir daí foram criadas a Agência Nacional do Petróleo - ANP, responsável pela regulação, fiscalização e contratação das atividades do setor e o Conselho Nacional de Política Energética, órgão encarregado de formular a política pública de energia. 
Em 2003, coincidindo com a comemoração dos seus 50 anos, a Petrobras dobrou a sua produção diária de óleo e gás natural ultrapassando a marca de 2 milhões de barris, no Brasil e no exterior. No dia 21 de abril de 2006, o presidente Luiz Inácio Lula da Silva deu início à produção da plataforma P-50, no Campo de Albacora Leste, na Bacia de Campos, o que permitiu ao Brasil atingir auto-suficiência em petróleo.

Além das atividades da holding, o Sistema Petrobras inclui subsidiárias - empresas independentes com diretorias próprias, interligadas à sede. Além disso, há o Centro de Aperfeiçoamento e Pesquisas de Petróleo - CENPES, em parceria com a Universidade Federal do Rio de Janeiro (UFRJ), o centro de pesquisas da Petrobras, que adquiriu renome internacional nos últimos anos pelas tecnologias que desenvolve.

Sua visão até 2020 é assim expressa: "Seremos uma das cinco maiores empresas integradas de energia do mundo e a preferida pelos nossos públicos de interesse." Sua missão: “Atuar de forma segura e rentável, com responsabilidade social e ambiental, nos mercados nacional e internacional, fornecendo produtos e serviços adequados às necessidades dos clientes e contribuindo para odesenvolvimento do Brasil e dos países onde atua."

Compõem a política e diretrizes de Recursos Humanos da empresa: atrair e desenvolver; treinar e reter pessoas, investindo em seus talentos e aprimorando as competências técnicas e gerenciais, atendendo à dinâmica dos negócios visando sustentar a excelência competitiva; assegurar efetivos adequados aos objetivos dos negócios e promover práticas de compensação competitivas em relação ao mercado; assegurar efetivos adequados aos objetivos dos negócios e promover práticas de compensação competitivas em relação ao mercado; estimular uma cultura empresarial única e humanizada, que respeite os valores locais, valorize a consolidação e troca de conhecimentos e priorize o reconhecimento pelos resultados das equipes e das pessoas; estimular e reconhecer o exercício da cidadania pelos trabalhadores e apoiar as iniciativas vinculadas à responsabilidade social do Sistema Petrobras; manter um processo permanente de negociação para a construção de soluções com a representação sindical dos empregados; adequar as práticas de contratação de serviços, compatibilizando-as com as Políticas de RH, Gestão do Conhecimento, SMS e de Segurança da Informação sobre os negócios e atividades do Sistema Petrobras. 


\section{6. 1 Unidade: Rio - Base Rio}

A política de gestão dessa unidade é descrita da seguinte forma: “A UN-Rio, tendo como missão explorar e produzir óleo e gás nas concessões sob sua responsabilidade, declara-se comprometida com a melhoria contínua do seu Sistema de Gestão, visando a excelência do desempenho, através dos seguintes compromissos com as partes interessadas: assegurar aos acionistas e parceiros a rentabilidade e a agregação de valor ao negócio de E\&P; atender as demandas dos clientes em relação à prrodução, contribuindo com a cadeia de valor da Petrobras; assegurar à força de trabalho, a excelência na gestão de recursos humanos, bem como atingir padrões internacionais de segurança e saúde no trabalho; desenvolver as atividades com responsabilidade social, em conformidade com a legislação e demais requisitos subscritos pela Petrobras, atingindo padrões internacionais de prevenção à poluição; aprimorar as relações com fornecedores e incentivar a melhoria do seu desempenho." $\mathrm{O}$ quadro $\mathrm{n}^{\circ} .34$ apresenta o resultado da análise de conteúdo das quatro entrevistas realizadas nessa unidade.

\begin{tabular}{|c|c|c|c|}
\hline \multicolumn{4}{|c|}{$\begin{array}{c}\text { QUADRO No } \text { Q }^{34} \\
\text { RESULTADO DA ANÁLISE DE CONTEÚDO UNIDADE RIO BASE RIO }\end{array}$} \\
\hline \multirow{2}{*}{$\begin{array}{l}\text { Unidade de Codificação } \\
\text { Palavras-tema }\end{array}$} & \multirow[t]{2}{*}{ Palavras-chave ou Frases-chave } & \multicolumn{2}{|c|}{ Contagem } \\
\hline & & Presença & Ausência \\
\hline 1. Feedback & $\begin{array}{l}\text { Estímulo; } \\
\text { Evidência. }\end{array}$ & $\begin{array}{l}04 \\
04\end{array}$ & - \\
\hline 2. Interações & Integrantes dos diversos escalões. & 04 & - \\
\hline 3. Abertura & $\begin{array}{l}\text { Encorajamento para debates; } \\
\text { Ocorrência de debates. }\end{array}$ & $\begin{array}{l}04 \\
04\end{array}$ & $\begin{array}{ll}- \\
-\end{array}$ \\
\hline 4. Comunicações interpessoais & Ocorrência entre as áreas. & 04 & - \\
\hline 5. Emoções & Expressão. & 03 & 01 \\
\hline 6. Pensar, sentir e agir & Evidência de interface. & 04 & - \\
\hline 7. Tomada de decisão & Ocorrência de em grupo. & 04 & - \\
\hline 8. Comportamento intergrupal & Favorecendo o trabalho em equipe. & 04 & - \\
\hline 9. Participação & Estímulo à atitude de participação do empregado. & 04 & - \\
\hline 10. Envolvimento & $\begin{array}{l}\text { Estímulo à atitude de envolvimento do empregado } \\
\text { com os objetivos organizacionais. }\end{array}$ & 04 & - \\
\hline 11. Comprometimento & $\begin{array}{l}\text { Estímulo à atitude de comprometimento } \\
\text { (identificação) do empregado com os objetivos } \\
\text { organizacionais. }\end{array}$ & 04 & - \\
\hline 12. Expectativas & $\begin{array}{l}\text { Possibilidade de o empregado comunicar } \\
\text { expectativas em relação à organização; } \\
\text { Ocorrência de comunicação das expectativas da } \\
\text { organização em relação ao empregado. }\end{array}$ & 03 & $\begin{array}{l}01 \\
-\end{array}$ \\
\hline 13. Responsabilidades & $\begin{array}{l}\text { Estímulo para o empregado assumir responsabili- } \\
\text { dades sobre suas ações. }\end{array}$ & 04 & - \\
\hline 14. Engajamento & $\begin{array}{l}\text { Estímulo ao engajamento das pessoas aos objetivos } \\
\text { e metas organizacionais. }\end{array}$ & 04 & - \\
\hline 15. Características da unidade & $\begin{array}{l}\text { Estimulando as pessoas a despenderem esforços } \\
\text { para nela permanecerem. }\end{array}$ & 04 & - \\
\hline 16. Cooperação & $\begin{array}{l}\text { Estímulo à atitude de cooperação; } \\
\text { Evidência da cooperacão. }\end{array}$ & 04 & - \\
\hline
\end{tabular}




\begin{tabular}{|c|c|c|c|}
\hline \multirow{2}{*}{$\begin{array}{l}\text { Unidade de Codificação } \\
\text { Palavras-tema }\end{array}$} & \multirow[t]{2}{*}{ Palavras-chave ou Frases-chave } & \multicolumn{2}{|c|}{ Contagem } \\
\hline & & Presença & Ausência \\
\hline 17. Valorização & $\begin{array}{l}\text { Evidência da valorização de opiniões e descobertas } \\
\text { em relação à maneira de se obter resultados; } \\
\text { Evidência da valorização do trabalho. }\end{array}$ & 04 & - \\
\hline 18. Aprendizagem/reaprendizagem & $\begin{array}{l}\text { Reconhecimento da necessidade de aprendiza- } \\
\text { gem/reaprendizagem em relação ao trabalho. }\end{array}$ & 04 & - \\
\hline 19. Desenvolvimento & $\begin{array}{l}\text { Demonstração do estímulo ao desenvolvimento } \\
\text { pessoal e profissional na própria organização. }\end{array}$ & 04 & - \\
\hline 20. Incentivos & $\begin{array}{l}\text { Disponibilização de incentivos vinculados a } \\
\text { resultados obtidos pela equipe. }\end{array}$ & 04 & - \\
\hline 21. Reconhecimento & $\begin{array}{l}\text { As pessoas são capazes de: desenvolvimento, } \\
\text { confiança e colaboração. }\end{array}$ & 04 & - \\
\hline $\begin{array}{l}\text { 22. Características organizacionais } \\
\text { da unidade }\end{array}$ & $\begin{array}{l}\text { Atrair e reter pessoas de alto potencial e } \\
\text { qualificação para o trabalho. }\end{array}$ & 04 & - \\
\hline 23. Criação de condições & $\begin{array}{l}\text { Favoráveis à manutenção da motivação individual } \\
\text { para o trabalho; } \\
\text { Favoráveis à mobilização dos grupos em torno das } \\
\text { metas organizacionais. }\end{array}$ & 04 & - \\
\hline $\begin{array}{l}\text { 24. Estrutura organizacional da } \\
\text { unidade }\end{array}$ & $\begin{array}{l}\text { Valorizando somente o que a liderança determina; } \\
\text { Valorizando a iniciativa individual; } \\
\text { Valorizando o poder concentrado na liderança; } \\
\text { Valorizando a responsabilidade compartilhada. }\end{array}$ & $\begin{array}{c}- \\
03 \\
- \\
04\end{array}$ & $\begin{array}{l}04 \\
01 \\
04 \\
-\end{array}$ \\
\hline 25. Comunicação & $\begin{array}{l}\text { Acerca do que é esperado do desempenho das } \\
\text { pessoas; } \\
\text { Dos acontecimentos críticos que marcam a história } \\
\text { da unidade; } \\
\text { Ocupação da unidade em saber como está sendo } \\
\text { percebido o seu processo de comunicação formal e } \\
\text { informal. }\end{array}$ & $\begin{array}{l}04 \\
04 \\
04\end{array}$ & $\begin{array}{l}- \\
- \\
-\end{array}$ \\
\hline 26. Missão organizacional & $\begin{array}{l}\text { Ocupação da unidade em saber como está sendo } \\
\text { compreendida sua missão. }\end{array}$ & 04 & - \\
\hline 27. Valores & $\begin{array}{l}\text { Demonstração dos valores pelos quais se rege a } \\
\text { unidade; } \\
\text { Comunicação e/ou constatação, pelos empregados, } \\
\text { da coerência entre os valores e o sistema de gestão } \\
\text { da unidade. }\end{array}$ & 04 & - \\
\hline 28. Políticas & $\begin{array}{l}\text { Criação das condições de adaptação de políticas } \\
\text { integradas de recursos humanos à realidade da } \\
\text { organização e ao seu contexto de atuação. }\end{array}$ & 04 & - \\
\hline
\end{tabular}

As unidades de codificação 1 a 8 dizem respeito às palavras-tema contidas nos aspectos do comportamento organizacional. A contagem de presenças é totalitárias na maioria absoluta dessas unidades de codificação, seguida de presenças expressivas na unidade de codificação 5, mostrando uma visão favorável dos entrevistados em relação aos aspectos ligados ao comportamento organizacional.

As unidades de codificação 9 a 16 estão voltadas para as palavras-tema contidas nos aspectos do comprometimento organizacional. A contagem de presenças é totalitária na maioria das unidades de codificação e expressiva na unidade de codificação 12 (frase-chave 1) o que denota favorabilidade, na percepção dos entrevistados, com relação a esses aspectos voltados para o comprometimento. 
As unidades de codificação 17 a 23 referem-se às palavras-tema contidas nos aspectos de gestão estratégica de pessoas. As presenças são totalizadoras em todas as unidades de codificação e denotam favorabilidade em relação a esses aspectos, na percepção dos entrevistados.

As unidades de codificação 24 a 28 estão no bojo das palavras-tema contidas nos aspectos da cultura organizacional. Registre-se, nesse quadro, a ausência encontrada na unidade de codificação 24 - estrutura organizacional da unidade, com as frases-chave "valorizando somente o que a liderança determina" e "valorizando o poder concentrado na liderança" o que mostra o aspecto positivo da falta de centralização, reforçado pela presença totalitária da frase-chave "valorizando a responsabilidade compartilhada" e significativa da frase-chave "valorizando a iniciativa individual".

As unidades de codificação 25, 26, 27 e 28 apresentam presenças absolutas, podendo denotar confirmação dos resultados percebidos nas demais unidades de codificação. O quadro $\mathrm{n}^{\mathrm{o}} 35$ apresenta o resultado da análise de conteúdo aplicadado ao escopo da pesquisa nessa unidade e contribui para aprofundar a compreensão do que foi mostrado no quadro $\mathrm{n}^{\mathrm{o}} 34$.

\begin{tabular}{|c|c|c|}
\hline \multicolumn{3}{|c|}{$\begin{array}{l}\text { QUADRO No. } 35 \\
\text { RESULTADO DA ANÁLISE DE CONTEÚDO APLICADO AO ESCOPO DA PESQUISA } \\
\text { UNIDADE RIO BASE RIO }\end{array}$} \\
\hline $\begin{array}{l}\text { Categorias de } \\
\text { Análise }\end{array}$ & Temas Significativos & Unidade de Codificação \\
\hline $\begin{array}{c}\text { Comportamento } \\
\text { Organizacional }\end{array}$ & $\begin{array}{l}\text { Percepção da con- } \\
\text { tribuição dos indiví- } \\
\text { duos, dos grupos e da } \\
\text { estrutura. }\end{array}$ & $\begin{array}{l}\text { "A estrutura contribui para agregar valor e melhorar o sistema de } \\
\text { gestão, com foco no negócio e na tecnologia." } \\
\text { "A estrutura contribui ao propiciar as condições adequadas à } \\
\text { permanência das pessoas no trabalho. Contribui, sobretudo, ao abrir } \\
\text { espaço adequado para ouvir as necessidades das pessoas." } \\
\text { "Os indivíduos contribuem com as suas competências e os seus } \\
\text { conhecimentos no grupo, em prol da melhoria dos resultados da } \\
\text { unidade." } \\
\text { "A estrutura contribui com o ouvir ativo para que os potenciais de } \\
\text { solução possam ser capitalizados. O objetivo é comum. Isso é bonito e } \\
\text { dá inspração para trabalhar." } \\
\text { "Uma unidade de negócio de extração e produção de petróleo como a } \\
\text { UN Rio, necessariamente opera em contribuição. São cinco os times } \\
\text { para intercalonamento dos períodos de } 14 \text { x } 21 \text { dias." } \\
\text { "Os grupos se alheias à realidade da empresa } 21 \text { dias por mês. Nos } 14 \\
\text { dias de confinamento há cuidado especial nas horas de passagem de } \\
\text { serviço (chegada e saída de turmas)." }\end{array}$ \\
\hline
\end{tabular}




\begin{tabular}{|c|c|c|}
\hline & & $\begin{array}{l}\text { "A estrutura contribui com a prática de trazer os indivíduos ou grupos } \\
\text { de volta (após os } 21 \text { dias de folga). Por sua vez, eles contribuem com } \\
\text { o empenho e a dedicação necessários para o trabalho seguro." }\end{array}$ \\
\hline $\begin{array}{l}\text { Categorias de } \\
\text { Análise }\end{array}$ & Temas Significativos & Unidade de Codificação \\
\hline $\begin{array}{c}\text { Comprometimento } \\
\text { Organizacional }\end{array}$ & $\begin{array}{l}\text { Percepção do orgulho e } \\
\text { do empenho exercido } \\
\text { pelos indivíduos em } \\
\text { favor dessa unidade. }\end{array}$ & $\begin{array}{l}\text { "O orgulho é fartamente demonstrado por diversos meios." } \\
\text { "O empenho vem antes do orgulho. O orgulho vem com a per-cepção } \\
\text { do valor da contribuição, via empenho, para o resultado final da } \\
\text { unidade." } \\
\text { "As pessoas são comprometidas com os resultados. O desem-penho é } \\
\text { fruto do empenho, com a dedicação, o conhecimento e vontade de } \\
\text { contribuir com a construção da sociedade." } \\
\text { "É muito bonita a história de amor à organização, um senti-mento de } \\
\text { brasilidade ao contribuir com o desenvolvimento do país." }\end{array}$ \\
\hline $\begin{array}{c}\text { Gestão Estratégica } \\
\text { de Pessoas }\end{array}$ & $\begin{array}{l}\text { Percepção da adoção de } \\
\text { novas práticas de } \\
\text { gestão, de modo a } \\
\text { facilitar as ações de } \\
\text { desenvolvimento e } \\
\text { resolução de conflitos } \\
\text { ness unidade. }\end{array}$ & $\begin{array}{l}\text { "Não há problema em contratar pessoas para o mar. O difíil é trazer as } \\
\text { pessoas do mar para a terra." } \\
\text { "Um atrativo que tivemos o cuidado de minimizar foi o paga-mento de } \\
\text { horas extras (durante os } 21 \text { dias) para participação em treinamentos. } \\
\text { Atualmente, só é aberto para treinamentos per-tinentes ao trabalho no } \\
\text { mar." } \\
\text { "As práticas adotadas que mais vêm facilitando são: ouvidoria; fale } \\
\text { com o RH; pesquisa de ambiência; criação e disseminação do } \\
\text { conhecimento." } \\
\text { "As pessoas que atuam em off shore precisam ter visão e infor-mação } \\
\text { para compreender claramente as etapas que envolvem as relações } \\
\text { entre campo e escritório." }\end{array}$ \\
\hline $\begin{array}{c}\text { Cultura } \\
\text { Organizacional }\end{array}$ & $\begin{array}{l}\text { Percepção do conhe- } \\
\text { cimento que os ind- } \\
\text { ivíduos têm, acerca da } \\
\text { visão, filosofia de } \\
\text { atuação, missão e } \\
\text { valores dessa unidade. }\end{array}$ & $\begin{array}{l}\text { "Os empregados conhecem visão, filosofia de atuação, missão e } \\
\text { valores, mas o trabalho de reforço se faz necessário, até por causa do } \\
\text { regime } 14 \text { x } 21 . " \\
\text { "No sistema de gestão integrado tudo é reforçado por todos." } \\
\text { "O trabalho de disseminação é intenso. Cada gestor contribui para } \\
\text { aprofundar contuamente o conhecimento do plano estratégico." } \\
\text { "Os embarques dos gerentes dos ativos e, eventualmente do RH, } \\
\text { ajudam com os princípios, visão, missão, valores, na concepção e na } \\
\text { prática diária." }\end{array}$ \\
\hline \multicolumn{3}{|c|}{ nte: a autora, com base nos dados da pesquisa. } \\
\hline
\end{tabular}

Em 1995, com a reestruturação, as pessoas ajudaram a preparar o segmento de exploração e produção para a transição, em paralelo à implantação do gerenciamento de desempenho e aprimoramento para que os indicadores refletissem melhor o resultado do negócio. Em 1997, com o término do monopólio, alguns problemas de mudança cultural ficaram evidenciados.

A partir de então, essa reestruturação incorporou a criação das unidades de negócio e as gerências por ativos. Tal mudança aprimorou o processo de contribuição das pessoas, como empresa integrada pelos ativos. A área de RH começou a ter importância estratégica e houve forte impacto na contribuição das pessoas. Paralelamente, o incremento das atividades dessa 
área tornou-se visível com a necessidade de formar as equipes após o período longo sem contratação. O desafio da gesta de pessoas é lidar com a diversidade cultural de todo o país, reunida a bordo das plataformas. Saber perceber, interagir e capitalizar as contribuições.

Uma unidade de extração e produção como a UN Rio, necessariamente opera em regime de contribuição. São cinco times para intercalamento dos períodos de 14 x 21 dias em cada plataforma. Esse regime de trabalho gera um grande afastamento mensal, no que diz respeito às comunicações da empresa e da unidade. A cada passagem de serviço, por turma embarcada, busca-se minimizar esse hiato criado.

Os grupos se alheiam à realidade da empresa 21 dias por mês e muitas vezes não acompanham o que é comunicado no sistema de gestão integrado. Mesmo havendo essa perda de comunicação, os 14 dias de confinamento são de significativa contribuição para os resultados obtidos na unidade.

Há cuidado especial nas horas de passagem de serviço (chegada e saída). Para os que optam em morar fora da base, os deslocamentos até Macaé ocorrem por conta do empregado. Dentro da base, tudo ocorre por conta da empresa.

As práticas de gestão são ferramentas oriundas da corporação, adotadas pela unidade para desenvolver, reter talentos e minimizar conflitos. Percebe-se a mudança de foco de gestão de pessoas, antes em RH, para os gestores gerentes, por meio de programas de aprimoramento dos que são oriundos das áreas técnicas - engenharia, tais como: programa de reconhecimento e recompensa; ouvidoria Petrobras; pesquisa de ambiência; fale com o RH; disseminação de conhecimento; ambientação dos recém-chegados com acompanhamento dos antigos; acompanhamento social off shore; diálogos em desenvovimento de equipes; desenvolvimento de supervisores; construção de relações profissionais; processo seletivo de nível médio, realizado localmente; trabalho de resgate das pessoas que atuam no regime 14 x 21 , o qual representa um desafio para a unidade, pois implica em retirar do foco, a incidência de horas extras como requisito para as pessoas participarem.

Os desafios de gestão de RH da unidade passam pela missão da corporação de "ser referência internacional, no segmento de energia, em gestão de pessoas, tendo seus empregados como seu maior valor." 
Os atrativos para uma unidade como essa são de duas dimensões: econômica, com proporcional sobre férias e feriados para os que trabalham embarcados (é tão atraente que uma das grandes dificuldades encontradas é recrutar quem tem experiência no mar para contribuir com uma equipe em terra); as pessoas podem morar em qualquer parte do Brasil e a grande maioria não mora no local da base. Não há necessidade de fazer deslocamentos com as famílias.

Essa unidade atrai muita gente do Nordeste. A base de operação é Macaé, onde a infraestrutura atual é vista como excelente. São dois os pontos de saída: Macaé, aeroporto da Infraero muito usado pela UN Rio; Farol de São Tomé, aeroporto da Petrobras, muito usado pela UN Bacia de Campos.

O orgulho é fartamente demonstrado por diversos meios como: celebração dos resultados da unidade; trabalho feito com dedicação e empenho em prol da manutenção da condição para celebrar; ambiência vista como favorável, em pesquisas realizadas; pertencer a empresa.

Esse orgulho é demonstrado desde o início. A modernidade da maioria das plataformas, a própria sede de operações, o volume de produção por plataforma, o desafio de operar em águas mais profundas, tudo é motivo de orgulho.

Reforce-se que os dados da pesquisa, nessa unidade, mostram chefias e colegas de todas as áreas e/ou da mesma área estimulando: feedbacks, debates, cooperação, valorização do trabalho, reconhecimento pela capacidade de desenvolvimento, confiabilidade e colaboração. Nesse ponto dá-se o cruzamento dos aspectos ligados a comportamento, comprometimento, gestão de pessoas e cultura organizacional, detalhados no quadro $\mathrm{n}^{\mathrm{o}} 34$.

\section{6. 2 Unidade: Rio - Base Macaé}

A base operacional de Macaé é a responsável pela operacionalização de plataformas ligadas à UN Bacia de Campos e UN Rio.

O quadro $n^{\circ} 36$ apresenta o resultado da análise de conteúdo das duas entrevistas realizadas nessa unidade. 


\begin{tabular}{|c|c|c|c|}
\hline \multicolumn{4}{|c|}{$\begin{array}{c}\text { QUADRO Nơ.36 } \\
\text { RESULTADO DA ANÁLISE DE CONTEÚDO UNIDADE RIO BASE MACAÉ }\end{array}$} \\
\hline \multirow{2}{*}{$\begin{array}{l}\text { Unidade de Codificação } \\
\text { Palavras-tema }\end{array}$} & \multirow{2}{*}{ Palavras-chave ou Frases-chave } & \multicolumn{2}{|c|}{ Contagem } \\
\hline & & Presença & Ausência \\
\hline 1. Feedback & $\begin{array}{l}\text { Estímulo; } \\
\text { Evidência. }\end{array}$ & - & $\begin{array}{c}02 \\
-\end{array}$ \\
\hline 2. Interações & Integrantes dos diversos escalões. & 01 & 01 \\
\hline 3. Abertura & $\begin{array}{l}\text { Encorajamento para debates; } \\
\text { Ocorrência de debates. }\end{array}$ & $\begin{array}{l}02 \\
02\end{array}$ & $\begin{array}{l}- \\
-\end{array}$ \\
\hline 4. Comunicações interpessoais & Ocorrência entre as áreas. & 01 & 01 \\
\hline 5. Emoções & Expressão. & 01 & 01 \\
\hline 6. Pensar, sentir e agir & Evidência de interface. & - & 02 \\
\hline 7. Tomada de decisão & Ocorrência de em grupo. & 02 & - \\
\hline 8. Comportamento intergrupal & Favorecendo o trabalho em equipe. & 02 & - \\
\hline 9. Participação & Estímulo à atitude de participação do empregado. & 02 & - \\
\hline 10. Envolvimento & $\begin{array}{l}\text { Estímulo à atitude de envolvimento do empregado } \\
\text { com os objetivos organizacionais. }\end{array}$ & 02 & - \\
\hline 11. Comprometimento & $\begin{array}{l}\text { Estímulo à atitude de comprometimento } \\
\text { (identificação) do empregado com os objetivos } \\
\text { organizacionais. }\end{array}$ & 02 & - \\
\hline 12. Expectativas & $\begin{array}{l}\text { Possibilidade de o empregado comunicar expecta- } \\
\text { tivas em relação à organização; } \\
\text { Ocorrência de comunicação das expectativas da } \\
\text { organização em relação ao empregado. }\end{array}$ & 01 & $\begin{array}{l}02 \\
01\end{array}$ \\
\hline 13. Responsabilidades & $\begin{array}{l}\text { Estímulo para o empregado assumir responsabili- } \\
\text { dades sobre suas ações. }\end{array}$ & 02 & - \\
\hline 14. Engajamento & $\begin{array}{l}\text { Estímulo ao engajamento das pessoas aos objetivos } \\
\text { e metas organizacionais. }\end{array}$ & 02 & - \\
\hline 15. Características da unidade & $\begin{array}{l}\text { Estimulando as pessoas a despenderem esforços } \\
\text { para nela permanecerem. }\end{array}$ & 01 & 01 \\
\hline 16. Cooperação & $\begin{array}{l}\text { Estímulo à atitude de cooperação; } \\
\text { Evidência da cooperação. }\end{array}$ & $\begin{array}{l}02 \\
02\end{array}$ & $\begin{array}{l}- \\
-\end{array}$ \\
\hline 17. Valorização & $\begin{array}{l}\text { Evidência da valorização de opiniões e descobertas } \\
\text { em relação à maneira de se obter resultados; } \\
\text { Evidência da valorização do trabalho. }\end{array}$ & 02 & - \\
\hline 18. Aprendizagem/reaprendizagem & $\begin{array}{l}\text { Reconhecimento da necessidade de aprendiza- } \\
\text { gem/reaprendizagem em relação ao trabalho. }\end{array}$ & 02 & - \\
\hline 19. Desenvolvimento & $\begin{array}{l}\text { Demonstração do estímulo ao desenvolvimento } \\
\text { pessoal e profissional na própria organização. }\end{array}$ & 02 & - \\
\hline 20. Incentivos & $\begin{array}{l}\text { Disponibilização de incentivos vinculados a } \\
\text { resultados obtidos pela equipe. }\end{array}$ & 01 & 01 \\
\hline 21. Reconhecimento & $\begin{array}{l}\text { As pessoas são capazes de: desenvolvimento, } \\
\text { confiança e colaboração. }\end{array}$ & 02 & - \\
\hline $\begin{array}{l}\text { 22. Características organizacio-nais } \\
\text { da unidade }\end{array}$ & $\begin{array}{l}\text { Atrair e reter pessoas de alto potencial e qualifi- } \\
\text { cação para o trabalho. }\end{array}$ & 02 & - \\
\hline 23. Criação de condições & $\begin{array}{l}\text { Favoráveis à manutenção da motivação individual } \\
\text { para o trabalho; } \\
\text { Favoráveis à mobilização dos grupos em torno das } \\
\text { metas organizacionais. }\end{array}$ & $\begin{array}{l}01 \\
01\end{array}$ & $\begin{array}{l}01 \\
01\end{array}$ \\
\hline $\begin{array}{l}\text { 24. Estrutura organizacional da } \\
\text { unidade }\end{array}$ & $\begin{array}{l}\text { Valorizando somente o que a liderança determina; } \\
\text { Valorizando a iniciativa individual; } \\
\text { Valorizando o poder concentrado na liderança; } \\
\text { Valorizando a responsabilidade compartilhada. }\end{array}$ & $\begin{array}{l}01 \\
01 \\
01 \\
02\end{array}$ & $\begin{array}{l}01 \\
01 \\
01 \\
-\end{array}$ \\
\hline 25. Comunicação & $\begin{array}{l}\text { Acerca do que é esperado do desempenho das } \\
\text { pessoas; } \\
\text { Dos acontecimentos críticos que marcam a história } \\
\text { da unidade; } \\
\text { Ocupação da unidade em saber como está sendo } \\
\text { percebido o seu processo de comunicação formal e } \\
\text { informal. }\end{array}$ & $\begin{array}{l}- \\
02 \\
02\end{array}$ & $\begin{array}{l}02 \\
- \\
-\end{array}$ \\
\hline 26. Missão organizacional & $\begin{array}{l}\text { Ocupação da unidade em saber como está sendo } \\
\text { compreendida sua missão. }\end{array}$ & 02 & - \\
\hline
\end{tabular}




\begin{tabular}{|l|l|c|c|}
\hline \multirow{2}{*}{$\begin{array}{c}\text { Unidade de Codificação } \\
\text { Palavras-tema }\end{array}$} & \multicolumn{1}{|c|}{ Palavras-chave ou Frases-chave } & \multicolumn{2}{c|}{ Contagem } \\
\cline { 2 - 4 } & $\begin{array}{l}\text { Presença } \\
\text { 27. Valores }\end{array}$ & $\begin{array}{l}\text { Ausência } \\
\text { unidade; } \\
\text { Comunicação e/ou constatação, pelos empregados, } \\
\text { da coerência entre os valores e o sistema de gestão } \\
\text { da unidade. }\end{array}$ & 01 \\
\hline 28. Políticas & $\begin{array}{l}\text { Criação das condições de adaptação de políticas } \\
\text { integradas de recursos humanos à realidade da } \\
\text { organização e ao seu contexto de atuação na } \\
\text { unidade. }\end{array}$ & 01 \\
\hline \multicolumn{2}{|l}{ Fonte: a autora, com base nos dados da pesquisa. } \\
\hline
\end{tabular}

As unidades de codificação 1 a 8 dizem respeito às palavras-tema contidas nos aspectos do comportamento organizacional. As presenças são mostradas nas unidades de codificação 1 (palavra-chave 2), 3, 7 e 8, e apresentam uma visão favorável dos entrevistados em relação aos aspectos ligados ao comportamento organizacional. As ausências contidas nas palavras-tema das unidades de codificação 1 (palavra chave 1), 2, 4, 5 e 6 não são desprezíveis e podem ser conduzidas a um diálogo investigativo das razões.

As unidades de codificação 9 a 16 estão voltadas para as palavras-tema contidas nos aspectos do comprometimento organizacional. A contagem de presenças é totalitária nas unidades de codificação 9,10,11,13,14, e 16,o que denota favorabilidade, na percepção dos entrevistados, com relação a esses aspectos voltados para o comprometimento. As unidades de codificação 12, (frases-chave 2) e 15 mostram que as ausências dividem-se com as presenças e sobrepõem-se na 12, (frases-chave 1), tornando-se significativas para investigação das razões que estão nelas embutidas.

As unidades de codificação 17 a 23 referem-se às palavras-tema contidas nos aspectos de gestão estratégica de pessoas. As presenças são totalizadoras nas unidades de codificação 17, 18, 19, 21 e 22. As ausências observadas nas unidades de codificação 20 e 23 (ambas as frases-chave) denotam necessidade de investigação para a compreensão das razões.

As unidades de codificação 24 a 28 estão no bojo das palavras-tema contidas nos aspectos da cultura organizacional. Registre-se, nesse quadro, a divisão entre ausência e presença encontrada na unidade de codificação 24 - estrutura organizacional da unidade, com as fraseschave "valorizando somente o que a liderança determina", "valorizando a iniciativa individual" e "valorizando o poder concentrado na liderança". A presença absoluta aparece na 
frase-chave "valorizando a responsabilidade compartilhada", fato que não deve ser considerado desprezível, merecendo investigação.

A unidade de codificação 25 (frases-chave 1) mostra ausência, enquanto as frases-chave 2 e 3 presenças. A 26 apresenta presença e as 27 e 28, divisão entre presença e ausência, podendo denotar necessidade de investigação das prováveis causa, na medida em que elas podem indicar percepções desfavoráveis, na visão dos entrevistados, no que tange aos aspectos concernentes à cultura dessa unidade.

O quadro $\mathrm{n}^{\mathrm{o}} 37$ apresenta o resultado da análise de conteúdo aplicadado ao escopo da pesquisa nessa unidade remota e contribui para aprofundar a compreensão do que foi mostrado no quadro $\mathrm{n}^{\circ} 36$.

\begin{tabular}{|c|c|c|}
\hline \multicolumn{3}{|c|}{$\begin{array}{l}\text { QUADRO No.37 } \\
\text { RESULTADO DA ANÁLISE DE CONTEÚDO APLICADO AO ESCOPO DA PESQUISA } \\
\text { UNIDADE RIO BASE MACAÉ }\end{array}$} \\
\hline $\begin{array}{c}\text { Categorias de } \\
\text { Análise }\end{array}$ & Temas Significativos & Unidade de Codificação \\
\hline $\begin{array}{c}\text { Comportamento } \\
\text { Organizacional }\end{array}$ & $\begin{array}{l}\text { Percepção da con- } \\
\text { tribuição dos indiví- } \\
\text { duos, dos grupos e da } \\
\text { estrutura. }\end{array}$ & $\begin{array}{l}\text { "O exercício de troca de feedback ainda não se dá como um } \\
\text { movimento natural da unidade." } \\
\text { "A estrutura propicia a aquisição de conhecimentos e aprendizagem. A } \\
\text { renovação é estimuladora." } \\
\text { "As pessoas caminham conjuntamente com a estrutura da empresa e } \\
\text { da unidade." }\end{array}$ \\
\hline $\begin{array}{c}\text { Comprometimento } \\
\text { Organizacional }\end{array}$ & $\begin{array}{l}\text { Percepção do orgulho e } \\
\text { do empenho exercido } \\
\text { pelos indivíduos em } \\
\text { favor dessa unidade. }\end{array}$ & $\begin{array}{l}\text { "Existem diferenças estruturais gerando demonstrações diferentes dos } \\
\text { aspectos que envolvem comprometimento nas realidades off shore e } \\
\text { on shore." } \\
\text { "O orgulho é demonstrado freqüentemente, inclusive pelos recém- } \\
\text { chegados." }\end{array}$ \\
\hline $\begin{array}{c}\text { Gestão Estratégica } \\
\text { de Pessoas }\end{array}$ & $\begin{array}{l}\text { Percepção da adoção de } \\
\text { novas práticas de } \\
\text { gestão, de modo a } \\
\text { facilitar as ações de } \\
\text { desenvolvimento e } \\
\text { resolução de conflitos } \\
\text { nessa unidade. }\end{array}$ & $\begin{array}{l}\text { "Pela especificidade do regime de trabalho, nem sempre tudo funciona } \\
\text { redondinho. Há necessidade de aproximação base-bordo. A depender } \\
\text { do gerente da plataforma, o processo fica mais facilitado." } \\
\text { "Os embarcados são acompanhados pelo RH da base." } \\
\text { "Há dificuldade em operacionalizar algumas ferramentas de gestão, } \\
\text { por problemas de comunicação para quem está desembarcado por } 21 \\
\text { dias, sem contato com a unidade ou com a empresa." }\end{array}$ \\
\hline $\begin{array}{c}\text { Cultura } \\
\text { Organizacional }\end{array}$ & $\begin{array}{l}\text { Percepção do conhe- } \\
\text { cimento que os indi- } \\
\text { víduos têm acerca da } \\
\text { visão, filosofia de } \\
\text { atuação, missão e va- } \\
\text { lores dessa unidade } \\
\text { remota. }\end{array}$ & $\begin{array}{l}\text { "Os conteúdos de visão, filosofia de atuação, missão e valores são } \\
\text { passados, pelos mais experientes, para os recém-admitidos que } \\
\text { estabelecem suas redes de comunicação." } \\
\text { "Há uma sistematização para os reforços, mas os líderes } \\
\text { responsabilizam-se por transmitir visão, filosofia de atuação, missão e } \\
\text { valores, diariamente nas reuniões." }\end{array}$ \\
\hline & & om base nos dados da pesquisa \\
\hline
\end{tabular}


Os dados da pesquisa mostram que a contribuição das pessoas é oriunda da forma como os gestores de cada plataforma posicionam-se diante das equipes. A estrutura de comunicação de cada um desses gestores pode facilitar ou dificultar a expressão de idéias/opiniões dessas pessoas, acerca do modo como realizam suas atividades. A estrutura das plataformas favorece, com o apoio das pessoas da base, para que os gestores possam atuar de forma mais efetiva.

A relação entre os mais experientes e os recém-admitidos tem demonstrado o processo de contribuição, com as experiências vividas para a recepção segura e orientadora, aos recémchegados. O empenho é expresso pela responsabilidade de passar os conhecimentos, compartilhar e influir nos resultados da unidade.

Em razão da mudança de foco de gestão de pessoas para os gestores gerentes, há um trabalho em desenvolvimento que visa a aprimorar a forma de gerir as pessoas. Um cuidado específico é observado no acompanhamento do trabalhador off shore, em que suas necessidades são ouvidas e as ações são empreendidas, como reunião de análise crítica com pauta colocada pela operação, realizada por vídeoconferência, por exemplo.

Atente-se que os dados da pesquisa, nessa unidade, mostram chefias e colegas de todas as áreas e/ou da mesma área, contando com o apoio da base, estimulando: feedbacks, debates, cooperação, valorização do trabalho, reconhecimento pela capacidade de desenvolvimento, confiabilidade e colaboração. Nesse ponto dá-se o cruzamento dos aspectos ligados a comportamento, comprometimento, gestão de pessoas e cultura organizacional, detalhados no quadro $\mathrm{n}^{\mathrm{o}} 36$. O desafio da base é fazer o alinhamento do RH, como consultoria interna, para o corpo gerencial nos processos das plataformas.

\section{6. 3 Unidade Rio - Plataforma P 40}

Essa plataforma é do tipo FPSO sistema flutuante de produção, armazenamento e transferência de óleo SS - plataforma semi-submersível e produz. Ela processa, armazenam e transfere o óleo.

Os FPSOs (Floating, Production, Storage and Offloading) são navios com capacidade para processar e armazenar o petróleo, e prover a transferência do petróleo e/ou gás natural. No convés do navio, é instalada uma planta de processo para separar e tratar os fluidos 
produzidos pelos poços. Depois de separado da água e do gás, o petróleo é armazenado nos tanques do próprio navio, sendo transferido para um navio aliviador de tempos em tempos. Esse navio aliviador é um petroleiro que atraca na popa da FPSO para receber o petróleo que foi armazenado em seus tanques e transportá-lo para terra. O gás comprimido é enviado para a terra através de gasodutos e/ou reinjetado no reservatório.

Os maiores FPSOs têm sua capacidade de processo em torno de 200 mil barris de petróleo por dia, com produção associada de gás de aproximadamente 2 milhões de metros cúbicos por dia. O quadro $\mathrm{n}^{\mathrm{o}} 38$ apresenta o resultado da análise de conteúdo das oito entrevistas realizadas nessa unidade.

\begin{tabular}{|c|c|c|c|}
\hline \multicolumn{4}{|c|}{$\begin{array}{c}\text { QUADRO No.38 } \\
\text { RESULTADO DA ANÁLISE DE CONTEÚDO UNIDADE RIO PLATAFORMA P } 40\end{array}$} \\
\hline \multirow{2}{*}{$\begin{array}{l}\text { Unidade de Codificação } \\
\text { Palavras-tema }\end{array}$} & \multirow[t]{2}{*}{ Palavras-chave ou Frases-chave } & \multicolumn{2}{|c|}{ Contagem } \\
\hline & & Presença & Ausência \\
\hline 1. Feedback & $\begin{array}{l}\text { Estímulo; } \\
\text { Evidência. }\end{array}$ & $\begin{array}{l}04 \\
08 \\
\end{array}$ & $\begin{array}{c}04 \\
-\end{array}$ \\
\hline 2. Interações & Integrantes dos diversos escalões. & 05 & 03 \\
\hline 3. Abertura & $\begin{array}{l}\text { Encorajamento para debates; } \\
\text { Ocorrência de debates. }\end{array}$ & $\begin{array}{l}06 \\
08\end{array}$ & 02 \\
\hline 4. Comunicações interpessoais & Ocorrência entre as áreas. & 07 & 01 \\
\hline 5. Emoções & Expressão. & 02 & 06 \\
\hline 6. Pensar, sentir e agir & Evidência de interface. & 01 & 07 \\
\hline 7. Tomada de decisão & Ocorrência de em grupo. & 07 & 01 \\
\hline 8. Comportamento intergrupal & Favorecendo o trabalho em equipe. & 08 & - \\
\hline 9. Participação & Estímulo à atitude de participação do empregado. & 08 & - \\
\hline 10. Envolvimento & $\begin{array}{l}\text { Estímulo à atitude de envolvimento do empregado } \\
\text { com os objetivos organizacionais. }\end{array}$ & 08 & - \\
\hline 11. Comprometimento & $\begin{array}{l}\text { Estímulo à atitude de comprometimento } \\
\text { (identificação) do empregado com os objetivos } \\
\text { organizacionais. }\end{array}$ & 08 & - \\
\hline 12. Expectativas & $\begin{array}{l}\text { Possibilidade de o empregado comunicar } \\
\text { expectativas em relação à unidade; } \\
\text { Ocorrência de comunicação das expectativas da } \\
\text { unidade em relação ao empregado. }\end{array}$ & $\begin{array}{l}02 \\
05\end{array}$ & $\begin{array}{l}06 \\
03\end{array}$ \\
\hline 13. Responsabilidades & $\begin{array}{l}\text { Estímulo para o empregado assumir responsa- } \\
\text { bilidades sobre suas ações. }\end{array}$ & 06 & 02 \\
\hline 14. Engajamento & $\begin{array}{l}\text { Estímulo ao engajamento das pessoas aos objetivos } \\
\text { e metas organizacionais. }\end{array}$ & 08 & - \\
\hline 15. Características da unidade & $\begin{array}{l}\text { Estimulando as pessoas a despenderem esforços } \\
\text { para nela permanecerem. }\end{array}$ & 07 & 01 \\
\hline 16. Cooperação & $\begin{array}{l}\text { Estímulo à atitude de cooperação; } \\
\text {.Evidência da cooperação. }\end{array}$ & $\begin{array}{l}08 \\
08\end{array}$ & $\begin{array}{l}- \\
-\end{array}$ \\
\hline 17. Valorização & $\begin{array}{l}\text { Evidência da valorização de opiniões e desco- } \\
\text { bertas em relação à maneira de se obter resultados; } \\
\text { Evidência da valorização do trabalho. }\end{array}$ & 06 & $\begin{array}{l}02 \\
-\end{array}$ \\
\hline 18. Aprendizagem/reaprendizagem & $\begin{array}{l}\text { Reconhecimento da necessidade de aprendiza- } \\
\text { gem/reaprendizagem em relação ao trabalho. }\end{array}$ & 04 & 04 \\
\hline 19. Desenvolvimento & $\begin{array}{l}\text { Demonstração do estímulo ao desenvolvimento } \\
\text { pessoal e profissional na própria organização. }\end{array}$ & 06 & 02 \\
\hline
\end{tabular}




\begin{tabular}{|c|c|c|c|}
\hline \multirow{2}{*}{$\begin{array}{l}\text { Unidade de Codificação } \\
\text { Palavras-tema }\end{array}$} & \multirow[t]{2}{*}{ Palavras-chave ou Frases-chave } & \multicolumn{2}{|c|}{ Contagem } \\
\hline & & Presença & Ausência \\
\hline 20. Incentivos & $\begin{array}{l}\text { Disponibilização de incentivos vinculados } \\
\text { resultados obtidos pela equipe. }\end{array}$ & 05 & 03 \\
\hline 21. Reconhecimento & $\begin{array}{l}\text { As pessoas são capazes de: desenvolvimento, } \\
\text { confiança e colaboração. }\end{array}$ & 08 & - \\
\hline $\begin{array}{l}\text { 22. Características organizacionais } \\
\text { da unidade }\end{array}$ & $\begin{array}{l}\text { Atrair e reter pessoas de alto potencial e qualifi- } \\
\text { cação para o trabalho. }\end{array}$ & 07 & 01 \\
\hline $\begin{array}{l}\text { 23. Criação de condições de trabalho } \\
\text { na unidade }\end{array}$ & $\begin{array}{l}\text { Favoráveis à manutenção da motivação individual } \\
\text { para o trabalho; } \\
\text { Favoráveis à mobilização dos grupos em torno das } \\
\text { metas organizacionais. }\end{array}$ & $\begin{array}{l}04 \\
06\end{array}$ & 04 \\
\hline $\begin{array}{l}\text { 24. Estrutura organizacional } \mathrm{da} \\
\text { unidade }\end{array}$ & $\begin{array}{l}\text { Valorizando somente o que a liderança deter-mina; } \\
\text { Valorizando a iniciativa individual; } \\
\text { Valorizando o poder concentrado na liderança; } \\
\text { Valorizando a responsabilidade compartilhada. }\end{array}$ & $\begin{array}{l}03 \\
03 \\
02 \\
08\end{array}$ & $\begin{array}{l}05 \\
05 \\
06 \\
-\end{array}$ \\
\hline 25. Comunicação & $\begin{array}{l}\text { Acerca do que é esperado do desempenho das } \\
\text { pessoas; } \\
\text { Dos acontecimentos críticos que marcam a história } \\
\text { da unidade; } \\
\text { Ocupação da unidade em saber como está sendo } \\
\text { percebido o seu processo de comunicação formal e } \\
\text { informal. }\end{array}$ & $\begin{array}{l}07 \\
08 \\
07\end{array}$ & $\begin{array}{l}01 \\
- \\
01\end{array}$ \\
\hline 26. Missão organizacional & $\begin{array}{l}\text { Ocupação da unidade em saber como está sendo } \\
\text { compreendida sua missão. }\end{array}$ & 06 & 02 \\
\hline 27. Valores & $\begin{array}{l}\text { Demonstração dos valores pelos quais se rege a } \\
\text { unidade; } \\
\text { Comunicação e/ou constatação, pelos empregados, } \\
\text { da coerência entre os valores e o sistema de gestão } \\
\text { da unidade. }\end{array}$ & 08 & $\begin{array}{l}- \\
-\end{array}$ \\
\hline 28. Políticas & $\begin{array}{l}\text { Criação das condições de adaptação de políticas } \\
\text { integradas de recursos humanos à realidade da } \\
\text { organização e ao seu contexto de atuação nessa } \\
\text { unidade. }\end{array}$ & 02 & 06 \\
\hline
\end{tabular}

As unidades de codificação 1 a 8 dizem respeito às palavras-tema contidas nos aspectos do comportamento organizacional. A contagem de presenças totalitárias nas unidades de codificação 1 (palavra-chave 2), 3 (frase-chave 2) e 8, seguida de presenças expressivas nas unidades de codificação 3 (frase-chave1), 4 e 7, mostra uma visão favorável dos entrevistados em relação aos aspectos ligados ao comportamento organizacional. As ausências contidas nas palavras-tema das unidades de codificação 1 (palavra-chave 1), 5 e 6 não são desprezíveis e podem ser conduzidas a um diálogo investigativo das razões.

As unidades de codificação 9 a 16 estão voltadas para as palavras-tema contidas nos aspectos do comprometimento organizacional. A contagem de presenças é totalitária nas unidades de codificação 9,10,11 14, e 16 e expressiva nas unidades de codificação 13 e 15, o que denota favorabilidade, na percepção dos entrevistados, com relação a esses aspectos voltados para o comprometimento. A unidade de codificação 12, em ambas as frases-chave mostra que as 
ausências são significativas e necessitam de investigação das razões que estão nelas embutidas.

As unidades de codificação 17 a 23 referem-se às palavras-tema contidas nos aspectos de gestão estratégica de pessoas. As presenças são totalizadoras nas unidades de codificação 17 (frase-chave 2) e 21; expressivas nas 17 (frase-chave 1), 19 e 23 (frase-chave 2). As ausências observadas nas unidades de codificação 18, 20, e 23 (frase-chave 1) denotam necessidade de investigação para a compreensão das razões.

As unidades de codificação 24 a 28 estão no bojo das palavras-tema contidas nos aspectos da cultura organizacional. Registre-se, nesse quadro, a ausência encontrada na unidade de codificação 24 - estrutura organizacional da unidade, com as frases-chave "valorizando somente o que a liderança determina", "valorizando a iniciativa individual" e "valorizando o poder concentrado na liderança". Encontra-se presença totalitária na frase "valorizando a responsabilidade compartilhada."

As unidades de codificação 25 (frase-chave 2) e 28 apresentam ausências totalitárias, seguidas de ausências substanciais nas substanciais, ns unidades de codificação 25 (frases-chave 1 e 3) e 26, podendo denotar necessidade de investigação das prováveis causas dessas ausências, na medida em que elas podem indicar percepções desfavoráveis, na visão dos entrevistados, no que tange aos aspectos concernentes à cultura dessa unidade remota. $\mathrm{O}$ quadro $\mathrm{n}^{\circ} 39$ apresenta o resultado da análise de conteúdo aplicadado ao escopo da pesquisa nessa unidade remota e contribui para aprofundar a compreensão do que foi mostrado no quadro $n^{\circ} 38$.

\begin{tabular}{|c|c|c|}
\hline \multicolumn{3}{|c|}{$\begin{array}{l}\text { QUADRO No.39 } \\
\text { RESULTADO DA ANÁLISE DE CONTEÚDO APLICADO AO ESCOPO DA PESQUISA } \\
\text { UNIDADE RIO PLATAFORMA P } 40\end{array}$} \\
\hline $\begin{array}{c}\text { Categorias de } \\
\text { Análise }\end{array}$ & Temas Significativos & Unidade de Codificação \\
\hline $\begin{array}{c}\text { Comportamento } \\
\text { Organizacional }\end{array}$ & $\begin{array}{l}\text { Percepção da con- } \\
\text { tribuição dos indiví- } \\
\text { duos, dos grupos e da } \\
\text { estrutura. }\end{array}$ & $\begin{array}{l}\text { "As pessoas contribuem sem barreiras e a história da empresa } \\
\text { contribui para que elas se expressem." } \\
\text { "A principal ferramenta é o diálogo honesto e transparente com as } \\
\text { pessoas e o resultado tende a ser melhor. Assim é que funciona a } \\
\text { estrutura off shore." } \\
\text { "A estrutura off shore contribui, detalhando as informações } \\
\text { necessárias e facilita para que } 95 \% \text { das questões sejam resolvidas a } \\
\text { bordo." }\end{array}$ \\
\hline
\end{tabular}




\begin{tabular}{|c|c|c|}
\hline $\begin{array}{l}\text { Comportamento } \\
\text { Organizacional } \\
\text { (continuação) }\end{array}$ & & $\begin{array}{l}\text { "As interações entre os diversos escalões da unidade compen-sam o } \\
\text { tempo de confinamento." } \\
\text { "A estrutura contribui com as condições geradas e facilita para que a } \\
\text { contribuição das pessoas seja efetiva." } \\
\text { "Interação humana a bordo é mais que um valor em nosso dia-a-dia." } \\
\text { "O 'petroleiro' é um entusiasta e, a despeito das dificuldades off shore } \\
\text { ele é empenhado em contribuir para que a empresa atinja, cada vez } \\
\text { mais, melhores resultados." }\end{array}$ \\
\hline $\begin{array}{c}\text { Categorias de } \\
\text { Análise }\end{array}$ & Temas Significativos & Unidade de Codificação \\
\hline $\begin{array}{c}\text { Comprometimento } \\
\text { Organizacional }\end{array}$ & $\begin{array}{l}\text { Percepção do orgulho e } \\
\text { do empenho exercido } \\
\text { pelos indivíduos em } \\
\text { favor dessa unidade. }\end{array}$ & $\begin{array}{l}\text { "O maior percentual do contingente é comprometido com os objetivos } \\
\text { e metas da plataforma." } \\
\text { "A interação e o convívio são intensos. Orgulho e empenho caminham } \\
\text { juntos. Os antigos passam para os novos que começaram a chegar em } \\
\text { 2001." } \\
\text { "As pessoas demonstram empenho e orgulho dentro da P40, inclusive } \\
\text { quando surgem situações de emergências e desafios." } \\
\text { "O orgulho de pertencer à empresa, principalmente da geração antiga, } \\
\text { é muito evidenciado." } \\
\text { "Há um sentimento de pertencimento muito forte." } \\
\text { "Falta mais envolvimento do pessoal off shore fora do período } \\
\text { embarcado." } \\
\text { "Além dos benefícios e remuneração privilegiada, há o orgulho pela } \\
\text { importância do trabalho off shore para o país inteiro." }\end{array}$ \\
\hline $\begin{array}{c}\text { Gestão Estratégica } \\
\text { de Pessoas }\end{array}$ & $\begin{array}{l}\text { Percepção da adoção de } \\
\text { novas práticas de } \\
\text { gestão, de modo a } \\
\text { facilitar as ações de } \\
\text { desenvolvimento e } \\
\text { resolução de conflitos } \\
\text { nessa unidade. }\end{array}$ & $\begin{array}{l}\text { "São realizadas reuniões mensais por videoconferência para discutir } \\
\text { problemas administrativos e planejar o acompanhamento." } \\
\text { "Há baixa rotatividade de pessoas dentro da P } 40 \text {. Todos sabem que } \\
\text { são imprescindíveis aqui dentro." } \\
\text { "Os elogios são feitos diante de toda a equipe e as críticas em } \\
\text { particular." } \\
\text { "O meio off shore eleva o gestor à condição de observador, orientador } \\
\text { e educador das pessoas." } \\
\text { "Sempre fui tido como um gestor muito duro. Aprendi a repensar a } \\
\text { intransigência e, hoje, liderar grupos em off shore é uma } \\
\text { tranqüilidade." } \\
\text { "Trabalhar com as pessoas é o grande desafio da experiência off } \\
\text { shore." }\end{array}$ \\
\hline $\begin{array}{c}\text { Cultura } \\
\text { Organizacional }\end{array}$ & $\begin{array}{l}\text { Percepção do conhe- } \\
\text { cimento que os indi- } \\
\text { víduos têm, acerca da } \\
\text { visão, filosofia de } \\
\text { atuação, missão e } \\
\text { valores dessa unidade. }\end{array}$ & $\begin{array}{l}\text { "A base operacional tem mais dificuldade de compreensão dos } \\
\text { aspectos relacionados a visão, filosofia de atuação, missão e valores, } \\
\text { mas as lideranças conhecem bem e passam a essência em suas ações." } \\
\text { "A essência de visão, filosofia de atuação, missão e valores é } \\
\text { conhecida, independente das palavras que a descrevem." } \\
\text { "Segurança, meio-ambiente e saúde são valores fortemente } \\
\text { internalizados no dia-a-dia." } \\
\text { "O conjunto se valores segurança, meio-ambiente e saúde é um } \\
\text { exemplo da necessidade de introjeção de valores, filosofia, missão e } \\
\text { visão, dentro da P 40." } \\
\text { "Segurança e responsabilidade socio-ambiental são fortemente } \\
\text { introjetados na plataforma e transportados para a família." }\end{array}$ \\
\hline \multicolumn{3}{|c|}{ onte: a autora, com base nos dados da pesquisa. } \\
\hline
\end{tabular}


A plataforma é considerada um ambiente hostil e, por conseqüência, necessita: interação, relaionamento cortês, ajuda mútua, lazer, amizade (na medida das possibilidades) e conviência saudável.

A infra-estrutura para atender esses requisitos é excepcional e dá todo o suporte para as atividades serem desenvolvidas de forma colaborativa, de acordo com os dados da pesquisa. O conceito de gerir pessoas, nessa realidade, é visto como mais importante do que as ferramentas. Olhos e ouvidos estão atentos para o que surge fora da normalidade, que possa afetar pessoas, material, máquinas e produção, sobretudo, que precise gerar soluções rápidas.

Algumas dessas ferramentas são destacadas, entretanto: sabadão, reunião para sugestões, reinvindicações, cobranças e trocas, na qual a participação é livre e os gestores estão sempre presentes; política de convivência saudável para todos os embarcados, independente de serem da empresa ou de terceirizadas; diálogo diário de segurança; reuniões semanais; programa de troca de feedback; desenvolvimento de equipes; desenvolvimento de supervisores; resolução de conflitos; visitas das assistentes sociais a bordo para levantamento de problemas sugeridos por pessoas embarcadas.

O empenho em fazer bem feito é percebido pelos entrevistados como muito grande e alimenta o orgulho. O comprometimento reflete-se nas ações cotidianas e, a entrega da área de trabalho para a equipe subseqüente, é destacada como excelente, na qual tudo é encontrado em perfeito funcionamento. Há, por trás dessas ações, a clareza de que os resultados são obtidos com o exercício das atividades de todos que compõem as cinco equipes que se revesam nos turnos.

Saliente-se que os dados da pesquisa, nessa plataforma, mostram chefias e colegas de todas as áreas e/ou da mesma área estimulando: feedbacks, debates, cooperação, valorização do trabalho, reconhecimento pela capacidade de desenvolvimento, confiabilidade e colaboração. Nesse ponto dá-se o cruzamento dos aspectos ligados a comportamento, comprometimento, gestão de pessoas e cultura organizacional, detalhados no quadro ${ }^{\circ} 38$.

\section{6. 4 Unidade Rio - Plataforma P 38}

Essa plataforma é do tipo SS sistema flutuante plataforma semi-submersível e não produz. Ela armazena e transfere o óleo. 
O quadro $n^{\circ} 40$ apresenta o resultado da análise de conteúdo das três entrevistas realizadas nessa unidade.

\begin{tabular}{|c|c|c|c|}
\hline \multicolumn{4}{|c|}{$\begin{array}{c}\text { QUADRO No. } 40 \\
\text { RESULTADO DA ANÁLISE DE CONTEÚDO UNIDADE RIO PLATAFORMA P } 38\end{array}$} \\
\hline \multirow{2}{*}{$\begin{array}{l}\text { Unidade de Codificação } \\
\text { Palavras-tema }\end{array}$} & \multirow[t]{2}{*}{ Palavras-chave ou Frases-chave } & \multicolumn{2}{|c|}{ Contagem } \\
\hline & & Presença & Ausência \\
\hline 1. Feedback & $\begin{array}{l}\text { Estímulo; } \\
\text { Evidência. }\end{array}$ & $\begin{array}{l}02 \\
03\end{array}$ & $\begin{array}{c}01 \\
-\end{array}$ \\
\hline 2. Interações & Integrantes dos diversos escalões. & 03 & - \\
\hline 3. Abertura & $\begin{array}{l}\text { Encorajamento para debates; } \\
\text { Ocorrência de debates. }\end{array}$ & $\begin{array}{l}02 \\
03\end{array}$ & $\begin{array}{c}01 \\
-\end{array}$ \\
\hline 4. Comunicações interpessoais & Ocorrência entre as áreas. & 03 & - \\
\hline 5. Emoções & Expressão. & 02 & 01 \\
\hline 6. Pensar, sentir e agir & Evidência de interface. & 01 & 02 \\
\hline 7. Tomada de decisão & Ocorrência de em grupo. & 03 & - \\
\hline 8. Comportamento intergrupal & Favorecendo o trabalho em equipe. & 02 & 01 \\
\hline 9. Participação & Estímulo à atitude de participação do empregado. & 03 & - \\
\hline 10. Envolvimento & $\begin{array}{l}\text { Estímulo à atitude de envolvimento do empregado } \\
\text { com os objetivos organizacionais. }\end{array}$ & 03 & - \\
\hline 11. Comprometimento & $\begin{array}{l}\text { Estímulo à atitude de comprometimento } \\
\text { (identificação) do empregado com os objetivos } \\
\text { organizacionais. }\end{array}$ & 03 & - \\
\hline 12. Expectativas & $\begin{array}{l}\text { Possibilidade de o empregado comunicar expecta- } \\
\text { tivas em relação à unidade. } \\
\text { Ocorrência de comunicação das expectativas da } \\
\text { unidade em relação ao empregado. }\end{array}$ & $\begin{array}{l}02 \\
02\end{array}$ & $\begin{array}{l}01 \\
01\end{array}$ \\
\hline 13. Responsabilidades & $\begin{array}{l}\text { Estímulo para o empregado assumir responsabili- } \\
\text { dades sobre suas ações. }\end{array}$ & 03 & - \\
\hline 14. Engajamento & $\begin{array}{l}\text { Estímulo ao engajamento das pessoas aos objetivos } \\
\text { e metas organizacionais. }\end{array}$ & 03 & - \\
\hline 15. Características da unidade & $\begin{array}{l}\text { Estimulando as pessoas a despenderem esforços } \\
\text { para nela permanecerem. }\end{array}$ & 03 & - \\
\hline 16. Cooperação & $\begin{array}{l}\text { Estímulo à atitude de cooperação; } \\
\text {.Evidência da cooperação. }\end{array}$ & $\begin{array}{l}03 \\
03\end{array}$ & $\begin{array}{l}- \\
-\end{array}$ \\
\hline 17. Valorização & $\begin{array}{l}\text { Evidência da valorização de opiniões e descobertas } \\
\text { em relação à maneira de se obter resultados; } \\
\text { Evidência da valorização do trabalho. }\end{array}$ & 02 & $\begin{array}{l}01 \\
- \\
\end{array}$ \\
\hline 18. Aprendizagem/reaprendizagem & $\begin{array}{l}\text { Reconhecimento da necessidade de apren- } \\
\text { dizagem/reaprendizagem em relação ao trabalho. }\end{array}$ & 01 & 02 \\
\hline 19. Desenvolvimento & $\begin{array}{l}\text { Demonstração do estímulo ao desenvolvimento } \\
\text { pessoal e profissional na própria organização. }\end{array}$ & 03 & - \\
\hline 20. Incentivos & $\begin{array}{l}\text { Disponibilização de incentivos vinculados a } \\
\text { resultados obtidos pela equipe. }\end{array}$ & 02 & 01 \\
\hline 21. Reconhecimento & $\begin{array}{l}\text { As pessoas são capazes de: desenvolvimento, } \\
\text { confiança e colaboração. }\end{array}$ & 03 & - \\
\hline 22. Características organizacionais & $\begin{array}{l}\text { Atrair e reter pessoas de alto potencial e } \\
\text { qualificação para o trabalho. }\end{array}$ & 03 & - \\
\hline 23. Criação de condições de trabalho & $\begin{array}{l}\text { Favoráveis à manutenção da motivação individual } \\
\text { para o trabalho; } \\
\text { Favoráveis à mobilização dos grupos em torno das } \\
\text { metas organizacionais. }\end{array}$ & $\begin{array}{l}03 \\
03\end{array}$ & - \\
\hline $\begin{array}{l}\text { 24. Estrutura organizacional da } \\
\text { unidade }\end{array}$ & $\begin{array}{l}\text { Valorizando somente o que a liderança determina; } \\
\text { Valorizando a iniciativa individual; } \\
\text { Valorizando o poder concentrado na liderança; } \\
\text { Valorizando a responsabilidade compartilhada. }\end{array}$ & $\begin{array}{l}- \\
02 \\
01 \\
03\end{array}$ & $\begin{array}{l}03 \\
01 \\
02 \\
-\end{array}$ \\
\hline
\end{tabular}




\begin{tabular}{|c|c|c|c|}
\hline \multirow{2}{*}{$\begin{array}{l}\text { Unidade de Codificação } \\
\text { Palavras-tema }\end{array}$} & \multirow[t]{2}{*}{ Palavras-chave ou Frases-chave } & \multicolumn{2}{|c|}{ Contagem } \\
\hline & & Presença & Ausência \\
\hline 25. Comunicação & $\begin{array}{l}\text { Acerca do que é esperado do desempenho das } \\
\text { pessoas; } \\
\text { Dos acontecimentos críticos que marcam a história } \\
\text { da unidade; } \\
\text { Ocupação da unidade em saber como está sendo } \\
\text { percebido o seu processo de comunicação formal e } \\
\text { informal. }\end{array}$ & $\begin{array}{l}02 \\
03 \\
02\end{array}$ & $\begin{array}{l}01 \\
- \\
01\end{array}$ \\
\hline 26. Missão organizacional & $\begin{array}{l}\text { Ocupação da unidade em saber como está sendo } \\
\text { compreendida sua missão. }\end{array}$ & 02 & 01 \\
\hline 27. Valores & $\begin{array}{l}\text { Demonstração dos valores pelos quais se rege a } \\
\text { unidade; } \\
\text { Comunicação e/ou constatação, pelos empre-gados, } \\
\text { da coerência entre os valores e o sistema de gestão } \\
\text { da unidade. }\end{array}$ & 03 & 01 \\
\hline 28. Políticas & $\begin{array}{l}\text { Criação das condições de adaptação de políticas } \\
\text { integradas de recursos humanos à realidade da } \\
\text { organização e ao seu contexto de atuação nessa } \\
\text { unidade. }\end{array}$ & 01 & 02 \\
\hline
\end{tabular}

As unidades de codificação 1 a 8 dizem respeito às palavras-tema contidas nos aspectos do comportamento organizacional. A contagem de presenças totalitárias nas unidades de codificação 1 (palavra-chave 2), 3 (frase-chave 2), 4 e 7, seguida de presenças expressivas nas unidades de codificação 1 (palavra-chave1), 3, 5 e 8, mostrando uma visão favorável dos entrevistados em relação aos aspectos ligados ao comportamento organizacional. As ausências contidas nas palavras-tema da unidade de codificação 6 são expressivas e podem ser conduzidas a um diálogo investigativo das razões.

As unidades de codificação 9 a 16 estão voltadas para as palavras-tema contidas nos aspectos do comprometimento organizacional. A contagem de presenças é totalitária nas unidades de codificação $9,10,11,13,14,15$ e 16 e expressiva na unidade de codificação 12, o que denota favorabilidade, na percepção dos entrevistados, com relação a esses aspectos voltados para o comprometimento.

As unidades de codificação 17 a 23 referem-se às palavras-tema contidas nos aspectos de gestão estratégica de pessoas. As presenças são totalizadoras nas unidades de codificação 17 (frase-chave 2), 19, 21 e 23 e expressivas nas 17 (frase-chave 1) e 22. As ausências observadas na unidade de codificação 18 , denotam necessidade de investigação para a compreensão das razões. 
As unidades de codificação 24 a 28 estão no bojo das palavras-tema contidas nos aspectos da cultura organizacional. Registre-se, nesse quadro, a ausência encontrada na unidade de codificação 24 - estrutura organizacional da unidade, com as frases-chave "valorizando somente o que a liderança determina" e "valorizando o poder concentrado na liderança", reforçadas pela presença das frases "valorizando a responsabilidade compartilhada" e "valorizando a iniciativa individual", o que denota favorabilidade.

As unidades de codificação 25 (frases-chave 2), 26 e 28 apresentam presenças totalitárias e a 25 (frases-chave 1 e 3), presenças expressivas, podendo denotar confirmação da favorabilidade. As ausências na unidade 28 podem apresentar necessidade de investigação das prováveis causas, na medida em que podem indicar percepções desfavoráveis, na visão dos entrevistados, no que tange a esses aspectos concernentes à cultura dessa unidade remota.

O quadro $\mathrm{n}^{\circ} 41$ apresenta o resultado da análise de conteúdo aplicadado ao escopo da pesquisa nessa unidade remota e contribui para aprofundar a compreensão do que foi mostrado no quadro $n^{\circ} 40$.

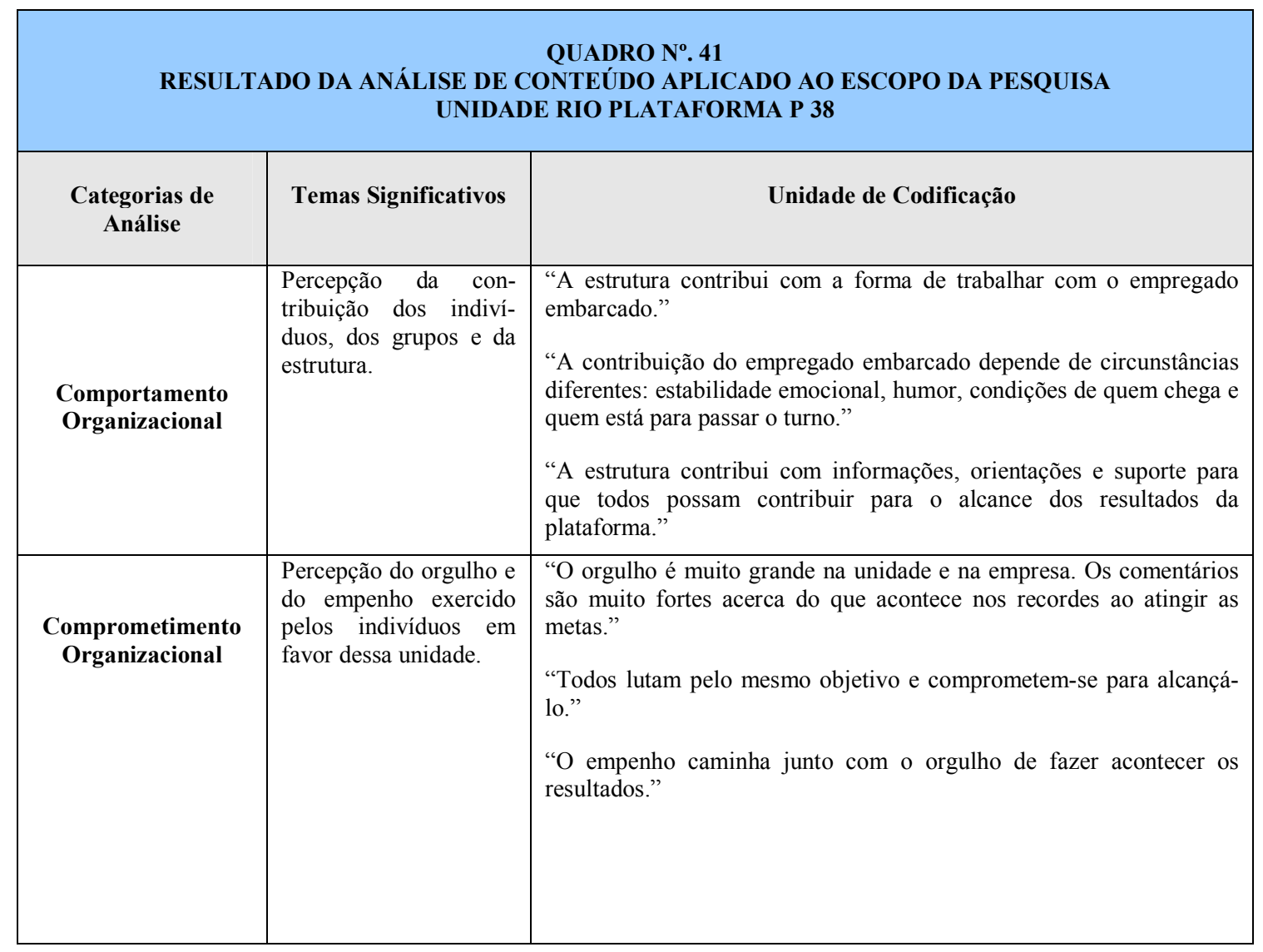




\begin{tabular}{|c|c|c|}
\hline $\begin{array}{c}\text { Categorias de } \\
\text { Análise }\end{array}$ & Temas Significativos & Unidade de Codificação \\
\hline $\begin{array}{c}\text { Gestão Estratégica } \\
\text { de Pessoas }\end{array}$ & $\begin{array}{l}\text { Percepção da adoção de } \\
\text { novas práticas de } \\
\text { gestão, de modo a } \\
\text { facilitar as ações de } \\
\text { desenvolvimento e } \\
\text { resolução de conflitos } \\
\text { nessa unidade. }\end{array}$ & $\begin{array}{l}\text { "Os gestores precisam preparar-se: psicologicamente, tecnicamente e } \\
\text { como gestores de pessoas." } \\
\text { "O trabalho com o lado humano é uma marca necessariamente } \\
\text { indiscutível." } \\
\text { "O trabalho de reintegração a cada embarque, trazendo as noções de } \\
\text { concentração e responsabilidade." } \\
\text { "A experiência de lidar com a diversidade de culturas na plataforma é } \\
\text { muito rica e de muita reponsabilidade para o gestor." }\end{array}$ \\
\hline $\begin{array}{c}\text { Cultura } \\
\text { Organizacional }\end{array}$ & $\begin{array}{l}\text { Percepção do conhe- } \\
\text { cimento que os indi- } \\
\text { víduos têm, acerca da } \\
\text { visão, filosofia de } \\
\text { atuação, missão e } \\
\text { valores dessa unidade. }\end{array}$ & $\begin{array}{l}\text { "Os gestores têm mais conhecimento e estão mais envolvidos no } \\
\text { processo de difusão da visão, filosofia de atuação, missão e valores } \\
\text { para os liderados." }\end{array}$ \\
\hline \multicolumn{3}{|c|}{ Fonte: a autora, com base nos dados da pesquisa. } \\
\hline
\end{tabular}

A prática de feedback é a mais utilizada na plataforma, como principal ponto do relacionamento para saber ouvir e receber a crítica. A maioria das pessoas da equipe olha-na com desconfiança, pois tem medo de prováveis punições. Esse medo é respeitado, sem perda da ênfase ao que pode ser incrementado para o desenvolvimento.

Reuniões diárias e semanais com temas próprios também servem de práticas, além de programa de visita das assistentes sociais da UN Rio a bordo; reunião mensal por videoconfereência para discutir questões administrativas; desenvolvimento de equipes, desenvolvimento de supervisores, organização do processo de rotina, gerenciamento de desempenho, eventos e palestras de qualidade de vida.

A contribuição das equipes é considerada alta, pelo menos para um contingente de $90 \%$, no qual, o comprometimento com os objetivos e metas da unidade é tido como indiscutível, principalmente na turma antiga, em que o orgulho de pertencer à unidade é muito grande e bastante evidenciado com a otimização dos recursos que as pessoas oferecem em situações de emergência.

$\mathrm{Na}$ ocasião em que, por determinação do governo, não era possível contratar pessoas, por exemplo, a identificação da equipe com a unidde e com a empresa ficou muito evidenciada, no esforço conjunto para alcançar os resultados. 
Elucide-se que os dados da pesquisa, nessa plataforma, mostram chefias e colegas de todas as áreas e/ou da mesma área estimulando: feedbacks, debates, cooperação, valorização do trabalho, reconhecimento pela capacidade de desenvolvimento, confiabilidade e colaboração. Nesse ponto dá-se o cruzamento dos aspectos ligados a comportamento, comprometimento, gestão de pessoas e cultura organizacional, detalhados no quadro $n^{\circ} 40$.

\section{6. 5 Unidade Rio - Plataforma P IV}

Essa plataforma é do tipo Navio-sonda, projetado para a perfuração de poços submarinos. Sua torre de perfuração localiza-se no centro do navio, onde uma abertura no casco permite a passagem da coluna de perfuração.

O sistema de posicionamento do navio-sonda, composto por sensores acústicos, propulsores e computadores, anula os efeitos do vento, ondas e correntes que tendem a deslocar o navio de sua posição.

O contingente das equipes é menor, oitenta e quatro pessoas operando por turma. A plataforma é móvel, tem 39 anos em operação e já passou por várias reformas. O quadro $n^{\circ} 42$ apresenta o resultado da análise de conteúdo das três entrevistas realizadas nessa unidade.

\begin{tabular}{|l|l|c|c|}
\hline \multicolumn{2}{|c|}{ RESULTADO DA ANÁLISE DE CONTEÚDO UNIDADE RIO PLATAFORMA P IV } \\
\hline \multirow{2}{*}{$\begin{array}{c}\text { Unidade de Codificação } \\
\text { Palavras-tema }\end{array}$} & \multicolumn{1}{|c|}{ Palavras-chave ou Frases-chave } & \multicolumn{2}{c|}{ Contagem } \\
\cline { 2 - 4 } & \multicolumn{1}{|c|}{ Presença } & Ausência \\
\hline 1. Feedback & Estímulo; & 03 & - \\
\hline 2. Interações & Evidência. & 03 & - \\
\hline 3. Abertura & Integrantes dos diversos escalões. & 03 & - \\
\hline 4. Comunicações interpessoais & Encorajamento para debates; & 03 & - \\
\hline 5. Emoções & Ocorrência de debates. & 03 & - \\
\hline 6. Pensar, sentir e agir & Ocorrência entre as áreas. & 03 & - \\
\hline 7. Tomada de decisão & Expressão. & 03 & - \\
\hline 8. Comportamento intergrupal & Evidência de interface. & 03 & - \\
\hline 9. Participação & Ocorrência de em grupo. & 03 & - \\
\hline 10. Envolvimento & Favorecendo o trabalho em equipe. & - \\
\hline 11. Comprometimento & Estímulo à atitude de participação do empregado. & 03 & - \\
\hline & $\begin{array}{l}\text { Estímulo à atitude de envolvimento do empregado } \\
\text { com os objetivos organizacionais. }\end{array}$ & 03 & - \\
\hline
\end{tabular}




\begin{tabular}{|c|c|c|c|}
\hline \multirow{2}{*}{$\begin{array}{l}\text { Unidade de Codificação } \\
\text { Palavras-tema }\end{array}$} & \multirow[t]{2}{*}{ Palavras-chave ou Frases-chave } & \multicolumn{2}{|c|}{ Contagem } \\
\hline & & Presença & Ausência \\
\hline 12. Expectativas & $\begin{array}{l}\text { Possibilidade de o empregado comunicar } \\
\text { expectativas em relação à unidade. } \\
\text { Ocorrência de comunicação das expectativas da } \\
\text { unidade em relação ao empregado. }\end{array}$ & 03 & - \\
\hline 13. Responsabilidades & $\begin{array}{l}\text { Estímulo para o empregado assumir responsabili- } \\
\text { dades sobre suas ações. }\end{array}$ & 03 & - \\
\hline 14. Engajamento & $\begin{array}{l}\text { Estímulo ao engajamento das pessoas aos objetivos } \\
\text { e metas organizacionais. }\end{array}$ & 03 & - \\
\hline 15. Características da unidade & $\begin{array}{l}\text { Estimulando as pessoas a despenderem esforços } \\
\text { para nela permanecerem. }\end{array}$ & 03 & - \\
\hline 16. Cooperação & $\begin{array}{l}\text { Estímulo à atitude de cooperação; } \\
\text { Evidência da cooperação. }\end{array}$ & $\begin{array}{l}03 \\
03\end{array}$ & $\begin{array}{ll}- \\
-\end{array}$ \\
\hline 17. Valorização & $\begin{array}{l}\text { Evidência da valorização de opiniões e descobertas } \\
\text { em relação à maneira de se obter resultados; } \\
\text { Evidência da valorização do trabalho. }\end{array}$ & 03 & - \\
\hline 18. Aprendizagem/reaprendizagem & $\begin{array}{l}\text { Reconhecimento da necessidade de aprendiza- } \\
\text { gem/reaprendizagem em relação ao trabalho. }\end{array}$ & 03 & - \\
\hline 19. Desenvolvimento & $\begin{array}{l}\text { Demonstração do estímulo ao desenvolvimento } \\
\text { pessoal e profissional na própria organização. }\end{array}$ & 03 & - \\
\hline 20. Incentivos & $\begin{array}{l}\text { Disponibilização de incentivos vinculados a } \\
\text { resultados obtidos pela equipe. }\end{array}$ & 03 & - \\
\hline 21. Reconhecimento & $\begin{array}{l}\text { As pessoas são capazes de: desenvolvimento, } \\
\text { confiança e colaboração. }\end{array}$ & 03 & - \\
\hline 22. Características organizacionais & $\begin{array}{l}\text { Atrair e reter pessoas de alto potencial e } \\
\text { qualificação para o trabalho. }\end{array}$ & 03 & - \\
\hline 23. Criação de condições de trabalho & $\begin{array}{l}\text { Favoráveis à manutenção da motivação individual } \\
\text { para o trabalho; } \\
\text { Favoráveis à mobilização dos grupos em torno das } \\
\text { metas organizacionais. }\end{array}$ & $\begin{array}{l}03 \\
03\end{array}$ & - \\
\hline $\begin{array}{l}\text { 24. Estrutura organizacional da } \\
\text { unidade }\end{array}$ & $\begin{array}{l}\text { Valorizando somente o que a liderança determina; } \\
\text { Valorizando a iniciativa individual; } \\
\text { Valorizando o poder concentrado na liderança; } \\
\text { Valorizando a responsabilidade compartilhada. }\end{array}$ & $\begin{array}{c}- \\
03 \\
- \\
03\end{array}$ & $\begin{array}{c}03 \\
- \\
03 \\
-\end{array}$ \\
\hline 25. Comunicação & $\begin{array}{l}\text { Acerca do que é esperado do desempenho das } \\
\text { pessoas; } \\
\text { Dos acontecimentos críticos que marcam a história } \\
\text { da unidade; } \\
\text { Ocupação da unidade em saber como está sendo } \\
\text { percebido o seu processo de comunicação formal e } \\
\text { informal. }\end{array}$ & $\begin{array}{l}03 \\
03 \\
03\end{array}$ & $\begin{array}{l}- \\
- \\
-\end{array}$ \\
\hline 26. Missão organizacional & $\begin{array}{l}\text { Ocupação da unidade em saber como está sendo } \\
\text { compreendida sua missão. }\end{array}$ & 03 & - \\
\hline 27. Valores & $\begin{array}{l}\text { Demonstração dos valores pelos quais se rege a } \\
\text { unidade; } \\
\text { Comunicação e/ou constatação, pelos empregados, } \\
\text { da coerência entre os valores e o sistema de gestão } \\
\text { da unidade. }\end{array}$ & $\begin{array}{l}03 \\
03\end{array}$ & - \\
\hline 28. Políticas & $\begin{array}{l}\text { Criação das condições de adaptação de políticas } \\
\text { integradas de recursos humanos à realidade da } \\
\text { organização e ao seu contexto de atuação nessa } \\
\text { unidade. }\end{array}$ & 02 & 01 \\
\hline
\end{tabular}

As unidades de codificação 1 a 8 dizem respeito às palavras-tema contidas nos aspectos do comportamento organizacional. A contagem de presenças totalitárias em todas essas unidades de codificação mostra a visão favorável dos entrevistados em relação aos aspectos ligados ao comportamento organizacional. 
As unidades de codificação 9 a 16 estão voltadas para as palavras-tema contidas nos aspectos do comprometimento organizacional. A contagem de presenças é totalitária, em todas essas unidades de codificação, o que denota a favorabilidade, na percepção dos entrevistados, com relação a esses aspectos voltados para o comprometimento.

As unidades de codificação 17 a 23 referem-se às palavras-tema contidas nos aspectos de gestão estratégica de pessoas. As presenças são totalizadoras em todas essas unidades de codificação e denotam percepção favorável com relação a esses aspectos.

As unidades de codificação 24 a 28 estão no bojo das palavras-tema contidas nos aspectos da cultura organizacional. Enfatize-se, nesse quadro, a ausência absoluta na unidade de codificação 24 - estrutura organizacional da unidade, com as frases-chave "valorizando somente o que a liderança determina" e "valorizando o poder concentrado na liderança", o que mostra a visão positiva com relação a poder e estrutura de comando. Tal percepção é reforçada pelas presenças totalizadoras das frases-chave "valorizando a responsabilidade compartilhada" e "valorizando a iniciativa individual."

As unidades de codificação 25, 26, 27 e 28 apresentam presenças totalizadoras, ratificando a percepção favorável dos entrevistados, no que tange aos aspectos concernentes à cultura dessa unidade remota. $\mathrm{O}$ quadro $\mathrm{n}^{\mathrm{o}} 43$ apresenta o resultado da análise de conteúdo aplicadado ao escopo da pesquisa nessa unidade remota e contribui para aprofundar a compreensão do que foi mostrado no quadro $n^{\circ} 42$.

\begin{tabular}{|c|l|l|}
\hline \multicolumn{2}{|c|}{ QUESULTADO DA ANÁLISE DE CONTEÚ No APLICADO AO ESCOPO DA PESQUISA } \\
UNIDADE RIO PLATAFORMA PIV
\end{tabular}




\begin{tabular}{|c|c|c|}
\hline $\begin{array}{l}\text { Categorias de } \\
\text { Análise }\end{array}$ & Temas Significativos & Unidade de Codificação \\
\hline $\begin{array}{c}\text { Comprometimento } \\
\text { Organizacional }\end{array}$ & $\begin{array}{l}\text { Percepção do orgulho e } \\
\text { do empenho exercido } \\
\text { pelos indivíduos em } \\
\text { favor dessa unidade. }\end{array}$ & $\begin{array}{l}\text { "O orgulho é indubitável na equipe como um todo." } \\
\text { "O orgulho está expresso nos recordes ao atingir as metas." } \\
\text { "Todos lutam pelo mesmo ideal e comprometem-se para alcançá-lo." } \\
\text { "O empenho caminha junto com o orgulho de fazer acontecer os } \\
\text { resultados." }\end{array}$ \\
\hline $\begin{array}{c}\text { Gestão Estratégica } \\
\text { de Pessoas }\end{array}$ & $\begin{array}{l}\text { Percepção da adoção de } \\
\text { novas práticas de } \\
\text { gestão, de modo a } \\
\text { facilitar as ações de } \\
\text { desenvolvimento e } \\
\text { resolução de conflitos } \\
\text { nessa unidade. }\end{array}$ & $\begin{array}{l}\text { "O trabalho de reintegração a cada embarque, trazendo as noções de } \\
\text { concentração e responsabilidade." } \\
\text { "A experiência de lidar com a diversidade de culturas na plataforma é } \\
\text { indescritível." } \\
\text { "O cuidado que se precisa ter é com a arrogância dos mais jovens, } \\
\text { pelo nível de escolaridade mais elevado que eles trazem." }\end{array}$ \\
\hline $\begin{array}{c}\text { Cultura } \\
\text { Organizacional }\end{array}$ & $\begin{array}{l}\text { Percepção do conhe- } \\
\text { cimento que os indi- } \\
\text { víduos têm, acerca da } \\
\text { visão, filosofia de } \\
\text { atuação, missão e } \\
\text { valores dessa unidade. }\end{array}$ & $\begin{array}{l}\text { "Os gestores têm mais conhecimento e estão mais envolvidos no } \\
\text { processo de difusão da visão, filosofia de atuação, missão e valores } \\
\text { para os liderados." } \\
\text { "As reuniões diárias enfatizam o sistema de gestão." }\end{array}$ \\
\hline
\end{tabular}

A contribuição das equipes é considerada alta, na qual o comprometimento com os objetivos e metas da unidade é tido como incontestável, principalmente na turma antiga, em que o orgulho de pertencer à empresa é muito grande.

Uma das dificuldades levantadas pelos entrevistados é como lidar com as pessoas que não se enquadram na função para a qual foram concursadas. Por outro lado, eles consideram que tal fato representa um desafio, na medida em que podem ser verificadas as habilidades com as quais essas pessoas podem realizar melhor as suas atividades.

Os desafios enfrentados no trato com a gestão de pessoas geram mais engajamento, orgulho e melhoria da relação interpessoal entre os integrantes das equipes. A exigência nos concursos tem resutado no engajamento gradual dos antigos com os novos, sempre com a desafiadora tarefa de colocar a pessoa certa no lugar certo. A carga de informação que os recém-chegados recebem em seis meses é considerada alta pelos entrevistados.

Elucide-se que os dados da pesquisa, nessa plataforma, mostram chefias e colegas de todas as áreas e/ou da mesma área estimulando: feedbacks, debates, cooperação, valorização do trabalho, reconhecimento pela capacidade de desenvolvimento, confiabilidade e colaboração. 
Nesse ponto dá-se o cruzamento dos aspectos ligados a comportamento, comprometimento, gestão de pessoas e cultura organizacional, detalhados no quadro $n^{\circ} 40$.

Em outras plataformas móveis mais novas, a diversidade cultural ultrapassa as fronteiras brasileiras, desde a construção dessas plataformas até a sua operação.

\section{6. 6 Unidade Amazônia: Base Manaus}

A política de gestão da unidade Amazônia está assim descrita: “A UN-AM, ciente de sua atuação em um ambiente de negócios cada vez mais competitivo e considerando o desenvolvimento de suas atividades em uma área ambientalmente única, a Amazônia, estabelece e cumpre uma política de Gestão orientada para a excelência do desempenho, garantia da qualidade, conservação ambiental, prevenção de acidentes, proteção da saúde das pessoas e para a responsabilidade social."

Essa descrição é apresentada de forma alinhada à contribuição da Unidade como um todo para a missão da Petrobras, apresentada como: "Explorar e produzir gás natural e petróleo na Amazônia". O quadro n 44 apresenta o resultado da análise de conteúdo das seis entrevistas realizadas nessa unidade.

\begin{tabular}{|c|c|c|c|}
\hline \multicolumn{4}{|c|}{$\begin{array}{l}\text { QUADRO No } \text { Q }^{4} \\
\text { RESULTADO DA ANÁLISE DE CONTEÚDO UNIDADE AMAZÔNIA BASE MANAUS }\end{array}$} \\
\hline \multirow{2}{*}{$\begin{array}{l}\text { Unidade de Codificação } \\
\text { Palavras-tema }\end{array}$} & \multirow[t]{2}{*}{ Palavras-chave ou Frases-chave } & \multicolumn{2}{|c|}{ Contagem } \\
\hline & & Presença & Ausência \\
\hline 1. Feedback & $\begin{array}{l}\text { Estímulo; } \\
\text { Evidência. }\end{array}$ & $\begin{array}{l}06 \\
06\end{array}$ & - \\
\hline 2. Interações & Integrantes dos diversos escalões. & 05 & 01 \\
\hline 3. Abertura & $\begin{array}{l}\text { Encorajamento para debates; } \\
\text { Ocorrência de debates. }\end{array}$ & $\begin{array}{l}06 \\
06\end{array}$ & - \\
\hline 4. Comunicações interpessoais & Ocorrência entre as áreas. & 05 & 01 \\
\hline 5. Emoções & Expressão. & 05 & 01 \\
\hline 6. Pensar, sentir e agir & Evidência de interface. & 05 & 01 \\
\hline 7. Tomada de decisão & Ocorrência de em grupo. & 04 & 02 \\
\hline 8. Comportamento intergrupal & Favorecendo o trabalho em equipe. & 06 & - \\
\hline 9. Participação & Estímulo à atitude de participação do empregado. & 06 & - \\
\hline 10. Envolvimento & $\begin{array}{l}\text { Estímulo à atitude de envolvimento do empregado } \\
\text { com os objetivos organizacionais. }\end{array}$ & 06 & - \\
\hline 11. Comprometimento & $\begin{array}{l}\text { Estímulo à atitude de comprometimento } \\
\text { (identificação) do empregado com os objetivos } \\
\text { organizacionais. }\end{array}$ & 06 & - \\
\hline 12. Expectativas & $\begin{array}{l}\text { Possibilidade de o empregado comunicar } \\
\text { expectativas em relação à unidade; } \\
\text { Ocorrência de comunicação das expectativas da } \\
\text { organização em relação ao empregado. }\end{array}$ & 05 & 01 \\
\hline
\end{tabular}




\begin{tabular}{|c|c|c|c|}
\hline \multirow{2}{*}{$\begin{array}{l}\text { Unidade de Codificação } \\
\text { Palavras-tema }\end{array}$} & \multirow[t]{2}{*}{ Palavras-chave ou Frases-chave } & \multicolumn{2}{|c|}{ Contagem } \\
\hline & & Presença & Ausência \\
\hline 13. Responsabilidades & $\begin{array}{l}\text { Estímulo para o empregado assumir responsabili- } \\
\text { dades sobre suas ações. }\end{array}$ & 05 & 01 \\
\hline 14. Engajamento & $\begin{array}{l}\text { Estímulo ao engajamento das pessoas aos objetivos } \\
\text { e metas organizacionais. }\end{array}$ & 05 & 01 \\
\hline 15. Características da unidade & $\begin{array}{l}\text { Estimulando as pessoas a despenderem esforços } \\
\text { para nela permanecerem. }\end{array}$ & 06 & - \\
\hline 16. Cooperação & $\begin{array}{l}\text { Estímulo à atitude de cooperação; } \\
\text {.Evidência da cooperação. }\end{array}$ & 06 & - \\
\hline 17. Valorização & $\begin{array}{l}\text { Evidência da valorização de opiniões e descobertas } \\
\text { em relação à maneira de se obter resultados; } \\
\text { Evidência da valorização do trabalho. }\end{array}$ & $\begin{array}{l}05 \\
05 \\
\end{array}$ & $\begin{array}{l}01 \\
01\end{array}$ \\
\hline 18. Aprendizagem/reaprendizagem & $\begin{array}{l}\text { Reconhecimento da necessidade de aprendiza- } \\
\text { gem/reaprendizagem em relação ao trabalho. }\end{array}$ & 06 & - \\
\hline 19. Desenvolvimento & $\begin{array}{l}\text { Demonstração do estímulo ao desenvolvimento } \\
\text { pessoal e profissional na própria organização. }\end{array}$ & 06 & - \\
\hline 20. Incentivos & $\begin{array}{l}\text { Disponibilização de incentivos vinculados a } \\
\text { resultados obtidos pela equipe. }\end{array}$ & 04 & 02 \\
\hline 21. Reconhecimento & $\begin{array}{l}\text { As pessoas são capazes de: desenvolvimento, } \\
\text { confiança e colaboração. }\end{array}$ & 06 & - \\
\hline $\begin{array}{l}\text { 22. Características organizacionais } \\
\text { da unidade }\end{array}$ & $\begin{array}{l}\text { Atrair e reter pessoas de alto potencial e } \\
\text { qualificação para o trabalho. }\end{array}$ & 04 & 02 \\
\hline 23. Criação de condições de trabalho & $\begin{array}{l}\text { Favoráveis à manutenção da motivação individual } \\
\text { para o trabalho; } \\
\text { Favoráveis à mobilização dos grupos em torno das } \\
\text { metas organizacionais. }\end{array}$ & $\begin{array}{l}04 \\
06\end{array}$ & 02 \\
\hline $\begin{array}{l}\text { 24. Estrutura organizacional da } \\
\text { unidade }\end{array}$ & $\begin{array}{l}\text { Valorizando somente o que a liderança determina; } \\
\text { Valorizando a iniciativa individual; } \\
\text { Valorizando o poder concentrado na liderança; } \\
\text { Valorizando a responsabilidade compartilhada. }\end{array}$ & $\begin{array}{l}01 \\
06 \\
01 \\
06\end{array}$ & $\begin{array}{l}05 \\
- \\
05 \\
-\end{array}$ \\
\hline 25. Comunicação & $\begin{array}{l}\text { Acerca do que é esperado do desempenho das } \\
\text { pessoas; } \\
\text { Dos acontecimentos críticos que marcam a história } \\
\text { da unidade; } \\
\text { Ocupação da unidade em saber como está sendo } \\
\text { percebido o seu processo de comunicação formal e } \\
\text { informal. }\end{array}$ & $\begin{array}{l}06 \\
05 \\
06\end{array}$ & $\begin{array}{l}- \\
01 \\
-\end{array}$ \\
\hline 26. Missão organizacional & $\begin{array}{l}\text { Ocupação da unidade em saber como está sendo } \\
\text { compreendida sua missão. }\end{array}$ & 05 & 01 \\
\hline 27. Valores & $\begin{array}{l}\text { Demonstração dos valores pelos quais se rege a } \\
\text { unidade; } \\
\text { Comunicação e/ou constatação, pelos empregados, } \\
\text { da coerência entre os valores e o sistema de gestão } \\
\text { da unidade. }\end{array}$ & $\begin{array}{l}06 \\
06\end{array}$ & - \\
\hline 28. Políticas & $\begin{array}{l}\text { Criação das condições de adaptação de políticas } \\
\text { integradas de recursos humanos à realidade da } \\
\text { organização e ao seu contexto de atuação na } \\
\text { unidade. }\end{array}$ & 05 & 01 \\
\hline
\end{tabular}

As unidades de codificação 1 a 8 dizem respeito às palavras-tema contidas nos aspectos do comportamento organizacional. A contagem de presenças totalitárias nas unidades de codificação 1, 3 e 8, seguida de presenças expressivas nas unidades $2,4,5,6$ e 7, mostra a visão favorável dos entrevistados em relação aos aspectos ligados ao comportamento organizacional. 
As unidades de codificação 9 a 16 estão voltadas para as palavras-tema contidas nos aspectos do comprometimento organizacional. A contagem de presenças é totalitária nas unidades de codificação 9, 10,11, 15, e 16 e expressiva nas unidades de codificação 12,13 e 14, o que denota favorabilidade, na percepção dos entrevistados, com relação a esses aspectos voltados para o comprometimento.

As unidades de codificação 17 a 23 referem-se às palavras-tema contidas nos aspectos de gestão estratégica de pessoas. As presenças são totalizadoras nas unidades de codificação 18, 19, 21 e 23 (frase-chave 2) e expressivas na 17. As ausências observadas nas unidades de codificação 20, 22 e 23 (frase-chave 1) denotam necessidade de investigação para a compreensão das razões.

As unidades de codificação 24 a 28 estão no bojo das palavras-tema contidas nos aspectos da cultura organizacional. Registre-se, nesse quadro, a ausência encontrada na unidade de codificação 24 - estrutura organizacional da unidade, com as frases-chave "valorizando somente o que a liderança determina" e "valorizando o poder concentrado na liderança" mostrando o aspecto positivo da falta de centralização, o que é reforçado pela presença significativa das frases-chave "valorizando a responsabilidade compartilhada" e "valorizando a iniciativa individual".

A unidade de codificação 25 (frases-chave 1 e 3 ) apresenta presenças totalizadoras e presenças expressiva na frasechave 2. Registrem-se, ainda, presenças totalizadoras na 27 e expressivas nas 26 e 28, podendo indicar confirmação da percepção favorável, na visão dos entrevistados, no que tange aos aspectos concernentes à cultura dessa unidade remota.

O quadro $n^{\circ} 43$ apresenta o resultado da análise de conteúdo aplicadado ao escopo da pesquisa nessa unidade remota e contribui para aprofundar a compreensão do que foi mostrado no quadro $n^{\circ} 42$. 


\begin{tabular}{|c|c|c|}
\hline \multicolumn{3}{|c|}{$\begin{array}{l}\text { QUADRO No } \text { Q }^{\circ} \\
\text { RESULTADO DA ANÁLISE DE CONTEÚDO APLICADO AO ESCOPO DA PESQUISA } \\
\text { UNIDADE AMAZÔNIA BASE MANAUS }\end{array}$} \\
\hline $\begin{array}{l}\text { Categorias de } \\
\text { Análise }\end{array}$ & Temas Significativos & Unidade de Codificação \\
\hline $\begin{array}{l}\text { Comportamento } \\
\text { Organizacional }\end{array}$ & $\begin{array}{l}\text { Percepção da con- } \\
\text { tribuição dos indiví- } \\
\text { duos, dos grupos e da } \\
\text { estrutura. }\end{array}$ & $\begin{array}{l}\text { "As pessoas fazem a diferença e mostram a tendência ao equilíbrio } \\
\text { entre o técnico e o gerencial." } \\
\text { "Clareza e estímulo à contribuição fazem parte da estrutura da } \\
\text { unidade." } \\
\text { "O espírito de equipe aqui é muito forte. O destaque é para a unidade, } \\
\text { com cada um contribuindo com a sua parte." } \\
\text { "Há uma soma de esforços freqüentes, a unidade estimula o } \\
\text { desenvolvimento do trabalho e os indivíduos cobram o apoio } \\
\text { necessário." } \\
\text { "A contribuição das pessoas é oriunda do seu empenho, mesmo } \\
\text { daquelas que, costumeiramente, reclamam de tudo." } \\
\text { "Os anseios pessoais são diferentes e são atendidos, em detrimento do } \\
\text { ônus para a organização, em prol da contribuição." }\end{array}$ \\
\hline $\begin{array}{c}\text { Comprometimento } \\
\text { Organizacional }\end{array}$ & $\begin{array}{l}\text { Percepção do orgulho e } \\
\text { do empenho exercido } \\
\text { pelos indivíduos em } \\
\text { favor dessa unidade. }\end{array}$ & $\begin{array}{l}\text { "A capacidade de realização é alta, quando o empenho e a dedicação } \\
\text { podem ser aflorados. Os indicadores obtidos vêm das pessoas e elas } \\
\text { estão comprometidas com isso." } \\
\text { "As pessoas são motivadas e comprometidas. O gerente só precisa dar } \\
\text { o foco. Elas vêem a unidade com boas perspectivas, identifi-cam-se } \\
\text { com ela, gostam do que fazem e envolvem-se." } \\
\text { "A pesquisa anual de clima mostra o comprometimento elevado das } \\
\text { pessoas da unidade. O orgulho é expresso como o de construir e fazer } \\
\text { parte da história da unidade, da empresa, do país." } \\
\text { "Sem o comprometimento e a motivação não dá para ser feliz no } \\
\text { trabalho." } \\
\text { "Raríssimas são as pessoas que não demonstram orgulho por trabalhar } \\
\text { na unidade. Isso é notório. As pessoas não medem esforços para } \\
\text { mostrar que a empresa faz parte de suas vidas. Elas mostram a } \\
\text { importância de produzir petróleo no meio da floresta." }\end{array}$ \\
\hline $\begin{array}{c}\text { Gestão Estratégica } \\
\text { de Pessoas }\end{array}$ & $\begin{array}{l}\text { Percepção da adoção de } \\
\text { novas práticas de } \\
\text { gestão, de modo a } \\
\text { facilitar as ações de } \\
\text { desenvolvimento e } \\
\text { resolução de conflitos } \\
\text { nessa unidade. }\end{array}$ & $\begin{array}{l}\text { "As pessoas encontram-se naturalmente. Atualmente os gesto-res } \\
\text { disponibilizam-se para visitar o campo sistematicamente." } \\
\text { "O grupo é muito aberto e são os gestores os responsáveis por isso. } \\
\text { Eles podem facilitar ou dificultar." } \\
\text { "O rodízio de gerentes é saudável. É preciso ficar atento às } \\
\text { competências de pessoas das próprias unidades para a ascenção." } \\
\text { "Há insatisfação quando a pessoa é retirada do campo para a sede, } \\
\text { pela perda de } 60 \% \text { dos adicionais. As que estão muito comprometidas } \\
\text { não são transferidas." } \\
\text { "É difícil, por vezes, reter os talentos em Manaus, por conta de } \\
\text { adaptações familiares. Já houve perdas de excelentes profissionais" } \\
\text { "Em posição estratégica, não há um mecanismo de segurar os talentos } \\
\text { na unidade. A permanência das pessoas embarcadas exige muito dos } \\
\text { gestores, em termos de comunicação." } \\
\text { "Ir ao campo, se possível uma vez por semana, estar junto das pessoas, } \\
\text { é a única forma de ver os problemas e ajudar a resolvê-los." } \\
\text { "A estratégia é liderar pelo exemplo. Se assim não for, a credibilidade }\end{array}$ \\
\hline
\end{tabular}




\begin{tabular}{|c|c|c|}
\hline & & é nula." \\
\hline $\begin{array}{l}\text { Categorias de } \\
\text { Análise }\end{array}$ & Temas Significativos & Unidade de Codificação \\
\hline $\begin{array}{c}\text { Cultura } \\
\text { Organizacional }\end{array}$ & $\begin{array}{l}\text { Percepção do conheci- } \\
\text { mento que os indiví- } \\
\text { duos têm acerca da } \\
\text { visão, filosofia de } \\
\text { atuação, missão e } \\
\text { valores da unidade. }\end{array}$ & $\begin{array}{l}\text { "Os princípios são nossa cartilha e estão bem internalizados, talvez } \\
\text { não da forma como estão escritos." } \\
\text { "Os valores não são negociáveis." } \\
\text { "A rotatividade das pessoas na unidade, gerada pelo crescimento da } \\
\text { empresa, faz com que as especificidades da visão, filosofia de atuação, } \\
\text { missão e valores vão ganhando corpo aos poucos." } \\
\text { "Transparência e simplicidade vão permeando visão, filosofia de } \\
\text { atuação, missão e valores nessa unidade." } \\
\text { "A cultura de gestão ambiental está no sangue de todos da unidade. } \\
\text { Isso mexe com o brio das pessoas e mantém o orgulho em alta." }\end{array}$ \\
\hline
\end{tabular}

A unidade Amazônia, base Manaus, é constituída de gerência geral, gerências funcionais e setoriais, coordenadores e supervisores. Ela é a base de suporte à unidade Urucu. As pessoas que a compõem, vêm das mais diversas regiões do país. Os dados da pesquisa mostram que essa unidade tem uma equpe motivada e comprometida, desafiada para romper as barreiras. Entretanto, há clareza dos resquícios de posturas antigas, o que impede a comunicação de expectativas, não obstante a falta de restrições no momento atual.

Os entrevistados consideram que melhorar a ambiência entre os grupos de trabalho é uma questão de oferecer desafios às pessoas. O trabalho de gestão de pessoas é visto como perene, respaldado por um suporte organizacional de investimento elevado em capacitação. A forma como o gerente conduz suas atividades pode resultar em ações mais ou menos eficazes. Algumas situações precisam ser bem tratadas, a exemplo da retirada de uma pessoa do campo para a sede, pois, isso pode implicar em prejuízos para a vida pessoal, o que repercute diretamente na produtividade profissional.

Houve uma lacuna de dez anos sem contratação. Atualmente, os gestores ocupam-se em trabalhar a harmonização entre as gerações de antigos e de recém-chegados. Os que chegam são vistos como desprovidos de experiência e do sentimento de pertecer à história da unidade, mais voltados para si mesmos. Os mais antigos, são os que demonstram o orgulho por fazerem parte da história da unidade, com o empenho, a dedicação e o comprometimento com os resultados finais. Essas pessoas são consideradas como propagadoras desse orgulho por todo o país, pois têm a visão de que não produzem petóleo para a Petrobras, mas contribuem para a responsabilidade social, regional e do país como um todo. 
As práticas de gestão de pessoas vêm das diretrizes da corporação e suas especificidades são tratadas pelos gestores com liberdade plena de entender as necessidades da unidade e atuar sobre elas. Ocorrem, então, as reuniões de comitês de segurança, meio-ambiente e gestão; as melhorias de infra-estrutura dos alojamentos; aplicação do adicional que contempla a diferença para reter os talentos na região; discussões acerca das possibilidades de desenvolver atividades rentáveis com a floresta em pé; definição de sistema de identificação de potenciais gerentes, em sintonia com as especificidades da unidade, pois só o corporativo não funcionaria; ajustamento das agendas para discussão dos procedimentos de busca de resultados, pelo fuso horário diferenciado; discussões sobre as implicações de busca de mecanismos, habilidades, participação e capitalização de conhecimentos das pessoas; ênfase aos valores segurança, saúde e meio-ambiente; quartas do conhecimento, com registro no sistema e representando um estímulo aos professores internos, o que vem retirando o estigma de que treinamento só ocorre quando se viaja para outra unidade.

São percebidas, ainda, como práticas de gestão: o avanço de nível e promoção homenagens, reconhecimentos, recompensas, programa de preparação de gestores: capacitação /observação /capacitação, o adicional de Manaus é um diferencial da unidade, um atrativo financeiro, não só para os que vêm de fora, mas todos recebem.

Para esses entrevistados há necessidade de se exercitar o feedback com mais coragem. É preciso que cada gestor acredite nessa necessidade. Eles consideram que dentro da base de Manaus é fácil. Em Urucu é mais complexo. O gerente fica na sede, alguns supervisores o fazem, outros não. O regime de 14 x 21 é muito complexo para gerir. Ainda se pratica o acréscimo de hora extra para treinamento nessa unidade, pois, não é fácil as pessoas participarem espontaneamente durante os 21 dias. O feedback é impactado também por essa ausência durante esses 21 dias.

Registre-se que os dados da pesquisa nessa unidade mostram chefias e colegas de todas as áreas e/ou da mesma área estimulando: feedbacks, debates, cooperação, valorização do trabalho, reconhecimento pela capacidade de desenvolvimento, confiabilidade e colaboração. Nesse ponto dá-se o cruzamento dos aspectos ligados a comportamento, comprometimento, gestão de pessoas e cultura organizacional, detalhados no quadro $\mathrm{n}^{\circ} 44$. 


\section{6. 7 Unidade: Urucu}

A Província Petrolífera de Urucu, localizada no coração da Floresta Amazônica, a 650 quilômetros a sudeste de Manaus, teve os seus esforços recompensados em 1986 com a descoberta de óleo e gás em níveis comerciais e o início de sua produção se deu em 1988.

Para a perfuração do primeiro poço, denominado de RUC-1 (Rio Urucu Número 1), os equipamentos seguiram de balsa numa viagem que durava em média dez dias, a partir de Manaus, pelo rio Solimões, até o pequeno porto fluvial do rio Urucu. A partir do porto foi preciso fazer centenas de vôos de helicóptero para permitir a montagem da sonda modulada na floresta. Depois desses passos foram perfurados novos poços, resultando na descoberta de novos campos - Leste do Urucu (LUC), a partir de 1987 e atualmente com 26 poços. No Sudoeste do Urucu (SUC), a partir de 1988, Carapanaúba, Cupiúba em 1989 e atualmente com 25 poços. A partir desse conjunto de campos foi implantada uma infra-estrutura completa dentro da floresta. A equipe, que até então vivia em balsas-alojamentos, deixou de ser nômade, passando a habitar nos alojamentos fixos.

A sensibilidade ambiental, os impactos decorrentes de eventuais acidentes, a conscientização de que a Amazônia representa um patrimônio natural da humanidade e, como tal, a visibilidade internacional é um fato, são fatores que contribuem para a difusão de toda política de gestão da unidade. A Unidade de Negócio de Exploração e Produção da Amazônia, em função das operações de exploração e produção de óleo e gás desenvolvidas na região amazônica, torna imperativa a necessidade de considerar que o conceito de sustentabilidade, presente em todas as atividades da Petrobras, jamais seja esquecido nessa unidade.

Desse modo, a ocupação espacial, os processos, as tecnologias, as pesquisas científicas e o próprio modelo de gestão são orientados pelos temas e conceitos priorizados no processo de elaboração participativa das diretrizes de sustentabilidade, buscando o aprimoramento das suas atividades nessa região. $\mathrm{Na}$ unidade Urucu os acessos se dão por: barco e balsa para alimentos, mercadorias e retorno com os lixos recicláveis; avião 3 a 4 vôos por dia - acesso mais facilitado para as pessoas, até o aeroporto de Urucu e vans até a base operacional geólogo Pedro de Moura.

O quadro $n^{\circ} 46$ apresenta o resultado da análise de conteúdo das cinco entrevistas realizadas nessa unidade. 


\begin{tabular}{|c|c|c|c|}
\hline \multicolumn{4}{|c|}{$\begin{array}{l}\text { QUADRO Nº } 46 \\
\text { RESULTADO DA ANÁLISE DE CONTEÚDO UNIDADE AMAZÔNIA BASE URUCU }\end{array}$} \\
\hline \multirow{2}{*}{$\begin{array}{l}\text { Unidade de Codificação } \\
\text { Palavras-tema }\end{array}$} & \multirow[t]{2}{*}{ Palavras-chave ou Frases-chave } & \multicolumn{2}{|c|}{ Contagem } \\
\hline & & Presença & Ausência \\
\hline 1. Feedback & $\begin{array}{l}\text { Estímulo; } \\
\text { Evidência. }\end{array}$ & $\begin{array}{l}05 \\
05\end{array}$ & - \\
\hline 2. Interações & Integrantes dos diversos escalões. & 05 & - \\
\hline 3. Abertura & $\begin{array}{l}\text { Encorajamento para debates; } \\
\text { Ocorrência de debates. }\end{array}$ & $\begin{array}{l}05 \\
05\end{array}$ & $\begin{array}{l}- \\
-\end{array}$ \\
\hline 4. Comunicações Interpessoais & Ocorrência entre as áreas. & 05 & - \\
\hline 5. Emoções & Expressão. & 05 & - \\
\hline 6. Pensar, sentir e agir & Evidência de interface. & 05 & - \\
\hline 7. Tomada de decisão & Ocorrência de em grupo. & 05 & - \\
\hline 8. Comportamento intergrupal & Favorecendo o trabalho em equipe. & 05 & - \\
\hline 9. Participação & Estímulo à atitude de participação do empregado. & 05 & - \\
\hline 10. Envolvimento & $\begin{array}{l}\text { Estímulo à atitude de envolvimento do empregado } \\
\text { com os objetivos organizacionais. }\end{array}$ & 05 & - \\
\hline 11. Comprometimento & $\begin{array}{l}\text { Estímulo à atitude de comprometimento } \\
\text { (identificação) do empregado com os objetivos } \\
\text { organizacionais. }\end{array}$ & 05 & - \\
\hline 12. Expectativas & $\begin{array}{l}\text { Possibilidade de o empregado comunicar } \\
\text { expectativas em relação à unidade; } \\
\text { Ocorrência de comunicação das expectativas da } \\
\text { unidade em relação ao empregado. }\end{array}$ & $\begin{array}{l}05 \\
05\end{array}$ & - \\
\hline 13. Responsabilidades & $\begin{array}{l}\text { Estímulo para o empregado assumir responsabili- } \\
\text { dades sobre suas ações. }\end{array}$ & 05 & - \\
\hline 14. Engajamento & $\begin{array}{l}\text { Estímulo ao engajamento das pessoas aos objetivos } \\
\text { e metas organizacionais. }\end{array}$ & 05 & - \\
\hline 15. Características da unidade & $\begin{array}{l}\text { Estimulando as pessoas a despenderem esforços } \\
\text { para nela permanecerem. }\end{array}$ & 05 & - \\
\hline 16. Cooperação & $\begin{array}{l}\text { Estímulo à atitude de cooperação; } \\
\text {.Evidência da cooperação. }\end{array}$ & $\begin{array}{l}05 \\
05\end{array}$ & $\begin{array}{l}- \\
-\end{array}$ \\
\hline 17. Valorização & $\begin{array}{l}\text { Evidência da valorização de opiniões e desco- } \\
\text { bertas em relação à maneira de se obter resultados; } \\
\text { Evidência da valorização do trabalho. }\end{array}$ & $\begin{array}{l}05 \\
05\end{array}$ & - \\
\hline 18. Aprendizagem/reaprendizagem & $\begin{array}{l}\text { Reconhecimento da necessidade de aprendiza- } \\
\text { gem/reaprendizagem em relação ao trabalho. }\end{array}$ & 05 & - \\
\hline 19. Desenvolvimento & $\begin{array}{l}\text { Demonstração do estímulo ao desenvolvimento } \\
\text { pessoal e profissional na própria organização. }\end{array}$ & 05 & - \\
\hline 20. Incentivos & $\begin{array}{l}\text { Disponibilização de incentivos vinculados a } \\
\text { resultados obtidos pela equipe. }\end{array}$ & 05 & - \\
\hline 21. Reconhecimento & $\begin{array}{l}\text { As pessoas são capazes de: desenvolvimento, } \\
\text { confiança e colaboração. }\end{array}$ & 05 & - \\
\hline $\begin{array}{l}\text { 22. Características organizacionais } \\
\text { da unidade }\end{array}$ & $\begin{array}{l}\text { Atrair e reter pessoas de alto potencial e } \\
\text { qualificação para o trabalho. }\end{array}$ & 05 & - \\
\hline 23. Criação de condições de trabalho & $\begin{array}{l}\text { Favoráveis à manutenção da motivação individual } \\
\text { para o trabalho; } \\
\text { Favoráveis à mobilização dos grupos em torno das } \\
\text { metas organizacionais. }\end{array}$ & $\begin{array}{l}05 \\
05\end{array}$ & - \\
\hline $\begin{array}{l}\text { 24. Estrutura organizacional } \mathrm{da} \\
\text { unidade }\end{array}$ & $\begin{array}{l}\text { Valorizando somente o que a liderança determina; } \\
\text { Valorizando a iniciativa individual; } \\
\text { Valorizando o poder concentrado na liderança; } \\
\text { Valorizando a responsabilidade compartilhada. }\end{array}$ & $\begin{array}{c}- \\
05 \\
- \\
05\end{array}$ & $\begin{array}{l}05 \\
- \\
05 \\
-\end{array}$ \\
\hline 25. Comunicação & $\begin{array}{l}\text { Acerca do que é esperado do desempenho das } \\
\text { pessoas; } \\
\text { Dos acontecimentos críticos que marcam a história } \\
\text { da unidade; } \\
\text { Ocupação da unidade em saber como está sendo } \\
\text { percebido o seu processo de comunicação formal e } \\
\text { informal. }\end{array}$ & $\begin{array}{l}05 \\
05 \\
05\end{array}$ & $\begin{array}{l}- \\
- \\
-\end{array}$ \\
\hline
\end{tabular}




\begin{tabular}{|l|l|c|c|}
\hline \multicolumn{1}{|c|}{$\begin{array}{c}\text { Unidade de Codificação } \\
\text { Palavras-tema }\end{array}$} & \multicolumn{1}{c|}{ Palavras-chave ou Frases-chave } & \multicolumn{2}{c|}{ Contagem } \\
\cline { 2 - 4 } & & \multicolumn{1}{c|}{ Presença } & Ausência \\
\hline 26. Missão organizacional & $\begin{array}{l}\text { Ocupação da unidade em saber como está sendo } \\
\text { compreendida sua missão. }\end{array}$ & 05 & - \\
\hline 27. Valores & $\begin{array}{l}\text { Demonstração dos valores pelos quais se rege a } \\
\text { unidade; } \\
\text { Comunicação e/ou constatação, pelos empregados, } \\
\text { da coerência entre os valores e o sistema de gestão } \\
\text { da unidade. }\end{array}$ & 05 & - \\
\hline 28. Políticas & $\begin{array}{l}\text { Criação das condições de adaptação de políticas } \\
\text { integradas de recursos humanos à realidade da } \\
\text { organização e ao seu contexto de atuação. }\end{array}$ & 05 & - \\
\hline
\end{tabular}

As unidades de codificação 1 a 8 dizem respeito às palavras-tema contidas nos aspectos do comportamento organizacional. A contagem de presenças totalitárias em todas essas unidades de codificação mostra a visão favorável dos entrevistados em relação aos aspectos ligados ao comportamento organizacional.

As unidades de codificação 9 a 16 estão voltadas para as palavras-tema contidas nos aspectos do comprometimento organizacional. A contagem de presenças é totalitária, em todas essas unidades de codificação, o que denota a favorabilidade, na percepção dos entrevistados, com relação a esses aspectos voltados para o comprometimento.

As unidades de codificação 17 a 23 referem-se às palavras-tema contidas nos aspectos de gestão estratégica de pessoas. As presenças são totalizadoras em todas essas unidades de codificação e denotam percepção favorável com relação a esses aspectos.

As unidades de codificação 24 a 28 estão no bojo das palavras-tema contidas nos aspectos da cultura organizacional. Registre-se, nesse quadro, a ausência absoluta na unidade de codificação 24 - estrutura organizacional da unidade, com as frases-chave "valorizando somente o que a liderança determina" e "valorizando o poder concentrado na liderança", o que mostra a visão positiva com relação a poder e estrutura de comando. Tal percepção é reforçada pelas presenças totalizadoras das frases-chave "valorizando a responsabilidade compartilhada" e "valorizando a iniciativa individual."

As unidades de codificação 25, 26, 27 e 28 apresentam presenças totalizadoras, ratificando a percepção favorável dos entrevistados, no que tange aos aspectos concernentes à cultura dessa unidade remota. $\mathrm{O}$ quadro $\mathrm{n}^{\mathrm{o}} 47$ apresenta o resultado da análise de conteúdo aplicadado ao 
escopo da pesquisa nessa unidade remota e contribui para aprofundar a compreensão do que foi mostrado no quadro $n^{\circ} 46$.

\begin{tabular}{|c|c|c|}
\hline \multicolumn{3}{|c|}{$\begin{array}{l}\text { QUADRO No } \text { Q }^{\circ} \\
\text { RESULTADO DA ANÁLISE DE CONTEÚDO APLICADO AO ESCOPO DA PESQUISA } \\
\text { UNIDADE AMAZÔNIA BASE URUCU }\end{array}$} \\
\hline $\begin{array}{l}\text { Categorias de } \\
\text { Análise }\end{array}$ & Temas Significativos & Unidade de Codificação \\
\hline $\begin{array}{l}\text { Comportamento } \\
\text { Organizacional }\end{array}$ & $\begin{array}{l}\text { Percepção da con- } \\
\text { tribuição dos indiví- } \\
\text { duos, dos grupos e da } \\
\text { estrutura. }\end{array}$ & $\begin{array}{l}\text { "A estrutura provê todos os recursos. A tecnologia é atualizada o } \\
\text { tempo todo." } \\
\text { "As contribuições vêm, em decorrência da confiança depositada nas } \\
\text { pessoas." } \\
\text { "A estrutura contribui qualificando os técnicos, criando infra-estrutura } \\
\text { e, sobretudo, dando autonomia para a política de sustentabilidade ser } \\
\text { cumprida." } \\
\text { "Todo ano se comemora a descoberta do primeiro poço e do início da } \\
\text { produção aqui." }\end{array}$ \\
\hline $\begin{array}{c}\text { Comprometimento } \\
\text { Organizacional }\end{array}$ & $\begin{array}{l}\text { Percepção do orgulho e } \\
\text { do empenho exercido } \\
\text { pelos indivíduos em } \\
\text { favor dessa unidade. }\end{array}$ & $\begin{array}{l}\text { "O empenho, a dedicação e o comprometimento são mostrados na } \\
\text { pesquisa de clima." } \\
\text { "O orgulho ganha visivbilidade quando se faz parte de uma unidade } \\
\text { que contribui para a região, para o estado e para o país. Ele é percedo } \\
\text { nos funcionários próprios e nas terceirizadas." } \\
\text { "O aprendizado em Urucu é para a vida toda. O orgulho está } \\
\text { embutido nele." } \\
\text { "O orgulho em trabalhar na unidade é fortemente demonstrado em } \\
\text { todos os eventos." } \\
\text { "O pólo AM é a vida de quem começou desde o início. O orgulho em } \\
\text { saber que ajudou a montar a unidade traz o empenho e a dedicação } \\
\text { para continuar." } \\
\text { "Os antigos têm o orgulho de construir a história e encaram como se a } \\
\text { unidade fosse seu próprio negócio." }\end{array}$ \\
\hline $\begin{array}{c}\text { Gestão Estratégica } \\
\text { de Pessoas }\end{array}$ & $\begin{array}{l}\text { Percepção da adoção de } \\
\text { novas práticas de } \\
\text { gestão, de modo a } \\
\text { facilitar as ações de } \\
\text { desenvolvimento e } \\
\text { resolução de conflitos } \\
\text { nessa unidade. }\end{array}$ & $\begin{array}{l}\text { "O maior medo que o gestor pode ter é tornar-se inflexível." } \\
\text { "As pessoas não são divisíveis e é vital estar atento a esse aspecto para } \\
\text { aceitar o profissional como um ser humano." } \\
\text { "Ainda vivemos sob o fantasma da hierarquia. Precisamos encorajar } \\
\text { as pessoas a se expressarem mais." } \\
\text { "A unidade já serve de base para a corporação em algumas práticas." } \\
\text { "Contratados e própios só têm diferença nos crachás, pois eles têm as } \\
\text { mesmas opções de desenvolvimento e resolução de conflitos que os } \\
\text { funcionários próprios." } \\
\text { "As paixões das pessoas são as coisas que mais me prendem na } \\
\text { supervisão aqui na unidade. Essas paixões são como o combustível } \\
\text { para a unidade ser o que é." } \\
\text { "Enaltecer os pontos fortes das pessoas é a forma mais eficaz de gerir } \\
\text { as pessoas aqui." } \\
\text { "O supervisor precisa ser os olhos da equipe e prepará-la para andar } \\
\text { sozinha, dando-lhe o suporte diário" }\end{array}$ \\
\hline
\end{tabular}




\begin{tabular}{|c|c|c|}
\hline & & $\begin{array}{l}\text { "Ainda não vi, em meus } 23 \text { anos de trabalho na unidade, as pessoas } \\
\text { buscarem a delegacia regional do trabalho". }\end{array}$ \\
\hline $\begin{array}{l}\text { Categorias de } \\
\text { Análise }\end{array}$ & Temas Significativos & Unidade de Codificação \\
\hline $\begin{array}{c}\text { Cultura } \\
\text { Organizacional }\end{array}$ & $\begin{array}{l}\text { Percepção do conhe- } \\
\text { cimento que os } \\
\text { indivíduos têm, acerca } \\
\text { da visão, filosofia de } \\
\text { atuação, missão e } \\
\text { valores dessa unidade. }\end{array}$ & $\begin{array}{l}\text { "A responsabilidade socio-ambiental é um valor alto para toda a } \\
\text { unidade." } \\
\text { "Nas oficinas com a força de trabalho fala-se acerca de visão, filosofia } \\
\text { de atuação, missão e valores." } \\
\text { "As ações do plano de ambiência tratam de visão, filosofia de atuação, } \\
\text { missão e valores." } \\
\text { "Tanto no acompanhamento formal quanto na negociação diária do } \\
\text { acompanhamento relembram-se aspectos concernentes a visão, } \\
\text { filosofia de atuação, missão e valores." }\end{array}$ \\
\hline & & com base nos dados da pesquisa. \\
\hline
\end{tabular}

Os entrevistados consideram que a contribuição das pessoas nessa unidade está em linha com a extensão do valor do trabalho do indivíduo e do grupo para a sociedade. A melhoria contínua da comunicação em todos os níveis é considerada um destaque na obtenção do comprometimento organizacional.

A estrutura da unidade contribui mantendo o que existe no meio-ambiente, ao desenvolver as atividades com responsabilidade e segurança. As práticas de gestão nessa unidade incluem: atendimento médico, inclusive para a população ribeirinha; adicionais; pesquisa constante para equiparação salarial; diálogo diário de segurança, com as especificidades da região, antes de iniciar a jornada de trabalho; palestras e oficinas a cada embarque; o contratado terceirizado recebe o tratamento como integrante da força de trabalho própria; reunião de gestão da operação na chegada para os 14 dias; PRECOPER - Prevenção e controle de Perdas - reuniões que ocorrem aos finais de semana e reúnem toda a força de trabalho da unidade.

No que tange à responsabilidade ambiental, há o viveiro de orquidários com as espécies nativas para a reposição da flora nas áreas degradadas. Em relação à responsabilidade social, destaca-se o programa de combate à malária. No que tange à questão de saúde da força de trabalho, além do atendimento normal, a UTI aérea está sempre disponível, sem restrições de custos, para os casos de necessidade mais grave.

Os dados da pesquisa mostram que há harmonia no convívio, colaboração, confiança, ambiência e cooperação. Atrair e reter talentos são ações consideradas importantes para os gestores, uma vez que a empresa já oferece o atrativo financeiro, o qual é muito marccante. 
Os gestores entram com as ações de suporte, pois a atividade em sistema de confinamento é muito complexa.

As contribuições que essa unidade recebe são inúmeras e todos afirmam saber da responsabilidade de substituir, em 70\%, o consumo de energia elétrica nas termoelétricas, por gás natural. Discussões diárias geram ações com respeito aos impactos ambientais e esses entrevistados mostram que bombeio de gás é ação de muita responsabilidade, na qual as tomadas de decisão têm de ser rápidas. Levar o gás natural até Manaus e Porto Velho é o desafio da unidade.

A clareza da sustentabilidade é o que norteia esse desafio e está atrelada às metas de segurança, meio-ambiente e saúde. O slongam que circula na unidade é "Meta é um sonho com data marcada." O empenho e a dedicação andam juntos na unidade e todos sabem da sua responsabilidade

Os dados da entrevista elucidam que a função do supervisor passa, também, por entender as necessidades dos seus supervisionados e verificar o que é melhor para eles, alocá-los aonde poderão render mais, valorizá-los no que são bons e ajudá-los, sempre. Os canais de comunicação são: representantes dos empregados, posto de assistente social; coordenados, gerente, sindicato.

Enfatize-se que os dados da pesquisa, nessa unidade, mostram chefias e colegas de todas as áreas e/ou da mesma área estimulando: feedbacks, debates, cooperação, valorização do trabalho, reconhecimento pela capacidade de desenvolvimento, confiabilidade e colaboração. Nesse ponto dá-se o cruzamento dos aspectos ligados a comportamento, comprometimento, gestão de pessoas e cultura organizacional, detalhados no quadro $\mathrm{n}^{\circ} 46$.

Foram registradas diferenças e semelhanças entre as unidades constituintes desse caso e elas encontram-se condensadas na ilustração $n^{\circ} 07$. 
ILUSTRAÇÃO No. 07

DIFERENÇAS E SEMELHANÇAS ENTRE UNIDADES CASO 4. 6. PETROBRAS

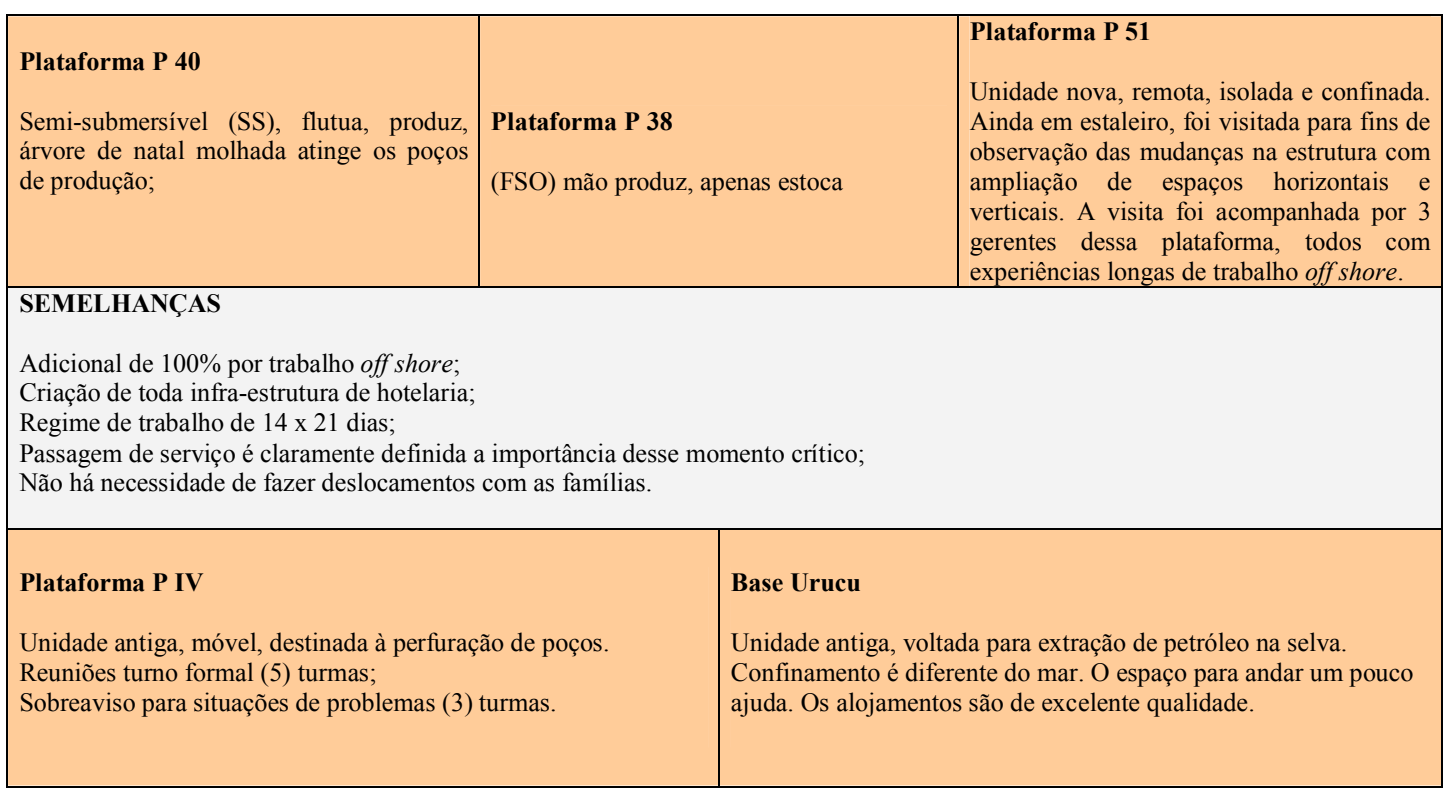

Fonte: a autora, com base nos dados da pesquisa.

Cada plataforma tem um perfil diferenciado. Alguns gestores ressaltaram que essa realidade eleva cada uma delas à condição de melhor escola de aprendizagem para exercer a sociabilidade, em virtude da diversidade de culturas, hábitos e costumes, convivendo em universo restrito. Os atrativos na plataforma são de ordem financeira, familiar e de aprendizagem de vida.

Os desafios para a retenção de talentos nessas unidades estão contidos na natureza do trabalho, nos adicionais financeiros, na conveniência para o empregado, na estrutura familiar e no tempo de folga. O percentual, para os que trabalham embarcados de turno, é de $110 \%$ a mais que do administrativo, em razão do confinamento, das periculosidades e das intempéries. O regime de trabalho é de 14 x 21 ou 15 x 27 (no qual as férias são diluídas na escala), o que só existe na Petrobras.

A convivência em confinamento é considerada ímpar para aumento da contribuição e as pessoas dão o melhor de si quando são ouvidas. Nas ocasiões de emergência ocorre otimização dos recursos e das pessoas, denotando a grande identificação com a empresa. As circunstâncias que impediram a contratação de pessoas por dez anos, mostraram a capacidade 
da força de trabalho, dedicação, empenho e muito orgulho por fazer parte da organização, não obstante a reconhecida sobrecarga nesse período sem reposição dos aposentados.

$\mathrm{Na}$ percepção dos entrevistados, a questão de retenção de talentos ameaça apresentar problemas desde o momento em que a empresa deixou de ser monopolista, o que significa dizer que os integrantes das novas gerações podem fazer escolhas por outras empresas no futuro. No atual momento, a maioria das empresas que entram é associada à Petrobras. Já estão sendo desenvolvidos trabalhos preventidos, entretanto.

As semelhanças mostram os traços que unem as pessoas, em todas essas unidades e em torno do mesmo propósito: reter talentos em todas elas, contribuindo com a empresa e com a região,com o país, por intermédio do desenpenho do papel social da empresa.

As diferenças denotam os aspectos ligados a comportamento, comprometimento, gestão de pessoas e cultura organizacional, todos eles em interação para a consecução desse propósito nesse caso 4.6. 


\section{DISCUSSÃO DOS RESULTADOS}

Considerando-se que os dados da pesquisa, em todas as unidades estudadas nos seis casos, mostram chefias e colegas de todas as áreas e/ou da mesma área estimulando: feedbacks, debates, cooperação, valorização do trabalho, reconhecimento pela capacidade de desenvolvimento, confiabilidade e colaboração dos indivíduos em prol dos resultados organizacionais e das interações entre as pessoas, os pressupostos teóricos assumidos no item 1.5 serão aqui retomados, integralmente, assim como alguns outros pontos localizados na fundamentação teórica, com a finalidade de se travar um diálogo teórico-empírico pertinente aos objetivos e à questão de pesquisa.

Analisando-se o pressuposto teórico de que as organizações são sistemas de pessoas, com caráter permanente, que visam a realizar um propósito e que contribuem para que elas tenham um modo de vida, desempenhando uma função social (PEREIRA, 2004) vê-se reforçado, nos seis casos, o modo de vida das pessoas em cada uma das unidades pesquisadas em suas peculiaridades e enfatizadas a função e a responsabilidade social. Destaque-se, para esse pressuposto, a Fundação ORSA (quadros $n^{\circ}$ s 26 e 27), no que tange à natureza do seu trabalho e às ações de responsabilidade social. Relembre-se, contudo, que não obstante as peculiaridades encontradas nas unidades remotas pesquisadas, a ênfase a esse aspecto é inerente a todas as empresas estudadas, quer pelo contexto próprio de aproximação com as comunidades ribeirinhas ou pela convivência com a diversidade cultural de todas as regiões do país, reunida em um mesmo ambiente.

Do mesmo modo, relembrando-se que a presente pesquisa assumiu a organização compreendida como uma entidade que interpreta o ambiente que a circunscreve, ao mesmo tempo em que o constrói por intermédio de suas ações (VASCONCELOS, 2004), cada uma das unidades pesquisadas encontra-se, de alguma maneira, empenhada na tarefa de interpretar o ambiente no qual está inserida e construí-lo por intermédio de suas ações, quer escolhendo a melhor forma para o agrupamento de recursos humanos e materiais (departamentalização) ou consolidando a definição de autoridade, atividades e comunicação (atribuições), necessárias para cumprir a sua missão organizacional ou, ainda, cuidando de (departamentalização e atribuições) para gerenciar a infra-estrutura denominada estrutura organizacional remota. 
Observando-se o pressuposto teórico de que a suposição é que, se comportamentos novos são aprendidos, se os indivíduos os desejam implementar e esses indivíduos se permitem fazê-lo, então, pelo contexto, eles o farão (ARGYRIS, 1993), fica visível, em cada um dos seis casos, tanto a capacidade de aprendizagem de comportamentos novos quanto o desejo e a permissão interna e externa aos indivíduos, de implementá-los em cada contexto no qual as unidades pesquisadas estão inseridas. Sobretudo, merecem destaque as três unidades da CADAM/PPSA (quadros $n^{\circ}$ s 16 - 21) e o Grupo ORSA (quadros $n^{\circ}$ s 22 - 27), pelo caráter diferenciado de convivência com os gestores.

No pressuposto teórico de que a formação ou operacionalização do comprometimento do colaborador ocorre em ambiente dinâmico, que exige freqüente atualização e enriquecimento da teoria e da prática relacionadas a esse constructo (CHANG, 2001), é percebido o movimento, nas seis empresas estudadas, da busca constante pela criação de condições favoráveis ao engajamento, à participação, ao envolvimento e ao comprometimento das pessoas com os objetivos organizacionais, observando-se os cuidados por parte dos gestores com o ambiente no qual as unidades estão inseridas. As plataformas e base na selva, da PETROBRAS (quadros $n^{\circ} \mathrm{s}$ 34 - 47), destacam esse pressuposto, pelo caráter extremamente diferenciado das realidades do mar e da floresta.

Com o pressuposto teórico de que para a formulação da estratégia de gestão de pessoas interessa aprofundar os aspectos relativos às dimensões humanas, ou seja, a cultura e as pessoas, e como a interação das pessoas com a estrutura e com o sistema pode contribuir para a consecução dos objetivos estratégicos da organização (ALBUQUERQUE, 2002), tem-se a observação do esforço engendrado pelas organizações estudadas, no sentido de contemplar os aspectos relativos às dimensões humanas, tanto nas unidades de trabalho quanto nos núcleos ou vilas residenciais, alojamentos e hotelarias das plataformas. Nesse pressuposto, todos os casos demonstram a força que coaduna com o pensamento do autor, ressaltando-se, entretanto, a Mineração Caraíba (quadros 28 e 29).

Verificando-se o pressuposto teórico de que uma forte cultura pressupõe o comprometimento dos empregados com os objetivos organizacionais (FLEURY; FLEURY, 1997) ficou evidenciada a sua presença, em todas as unidades, independente dos contextos nos quais elas estão inseridas. Duas premissas básicas subjacentes, também, foram evidenciadas: a cultura é produto da subjetividade humana; a contracultura permite que a organização mude ou se 
renove. O comprometimento com os objetivos organizacionais ficou constatado em todas as unidades pesquisadas, sem destaque especial para nenhum dos seis casos.

Torna-se relevante relembrar que, o conceito de comprometimento organizacional, para fins desta pesquisa, corresponde às bases que vinculam o indivíduo e a organização, as quais tanto podem estimular esse indivíduo a dispender esforços em prol da organização quanto reduzir a probabilidade de que ele venha a abandoná-la. As bases de vínculos encontradas em todas as unidades pesquisadas foram as que se inserem na perspectiva afetiva, preconizada pela literatura e detalhada na fundamentação teórica.

Relembre-se, ainda, que o modo como essas bases atuam, tanto para o individuo quanto para a organização, depende do contrato psicológico estabelecido entre ambos. Em todas as unidades das organizações pesquisadas e, de acordo com a classificação dada por Handy (1978), o predomínio do tipo de contrato cooperativo é o que melhor se encaixa na necessidade de dar fundamento a essas bases de vínculos nessas unidades remotas.

Retomando-se o significado do adjetivo afetivo na filosofia, com base em Abbagnano (2003) e observando-se que ele não se vincula ao da palavra afeto, já que designa, em geral, tudo o que se refere à esfera das emoções, as quais podem, por sua vez, referir-se tanto a pessoas quanto a coisas, fatos ou situações, constate-se que o significado de afetivo encontrado nas unidades pesquisadas (quadros $\mathrm{n}^{\mathrm{o}} \mathrm{s} 06-47$ ) está associado ao que os filósofos, comumente, consideram como necessidade de afeto: ser compreendido, assistido, ajudado nas dificuldades, seguido com o olhar benévolo e confiante. Os dados contidos nos quadros da análise de conteúdo de cada uma das unidades pesquisadas mostram a existência de valores que conduzem a esse significado, com evidência marcante de sinergia, solidariedade e confiança.

Alguns gerentes não residem nas localidades de algumas das unidades remotas, a exemplo de CADAM/PPSA (quadros $n^{\circ} \mathrm{s} 16-21$ ), Grupo ORSA (quadros $n^{\circ} \mathrm{s} 22$ - 27) e PETROBAS Urucu (quadros n⿳s 46 e 47), o que exige um trabalho consistente para que haja a sustentação das condições necessárias à sobrevivência digna das pessoas e à manutenção de suas motivações para permanecerem nessas unidades. Esses gerentes têm clareza que a distância pode gerar conflitos de difícil solução, assim como a descontinuidade das ações desencadeadas durante o período em que eles permanecem nessas unidades. 
Tal circunstância, vista por outro ângulo, pode contribuir para a possibilidade de criar comprometimento nessas unidades, sincronizando as suas metas com as de seus funcionários de modo que, ao procurar realizar suas próprias metas, o funcionário procure realizar também as metas da organização, conforme enfocado por (DESSLER, 1996).

O autor reforça que a criação do comprometimento de funcionários, forjando tal síntese, pode ajudá-los a reagir a condições adversas. Ele ajuda a entender que funcionários, sob essa perspectiva, poderão fazer seu trabalho como se fossem responsáveis diretos pelas unidades, na medida em que, uma vez comprometidos, dão o melhor de si para a organização e não necessitarão dos olhos vigilantes de uma equipe de supervisão para realizar suas atividades.

Além do que foi visto sob a ótica de Dessler (op.cit.), envolvimento, participação, compromisso, engajamento, decisão e escolha fazem parte do repertório de muitos estudiosos do comprometimento organizacional, referenciados na fundamentação teórica desta pesquisa, a exemplo de Salancik (1977), o qual aponta três elementos fundamentais para gerar comprometimento: a volição, a visibilidade e a irreversibilidade das ações. Ele enfatiza que esses elementos contêm sentimento e responsabilidade para com o curso da ação escolhido. Os dados contidos nos quadros da análise de conteúdo de cada uma das unidades remotas pesquisadas (quadros $\mathrm{n}^{\circ} \mathrm{s} 06$ - 47), salientando-se as três citadas anteriormente, (último parágrafo da página anterior) atestam a existência desses três elementos na geração do comprometimento organizacional.

Em linha com esse pensamento encontram-se as abordagens dos filósofos e da psicologia, mais especificamente da psicologia Rogeriana. Sob as condições de liberdade e responsabilidade por eles ressaltadas e pelo sentido trazido por Salancik (op.cit.), o comprometimento passa a ser mais que um compromisso, decisão ou escolha, podendo assumir um sentido de realização, pleno de propósito e significado. Esse sentido de realização fíca expresso na forma como o orgulho, o empenho e a dedicação são indistintamente evidenciados nos resultados da análise de conteúdo de cada uma das unidades das empresas estudadas (quadros 06 - 47).

Os desafios da evolução do conceito de gestão de pessoas, de acordo com Albuquerque (1999), por meio da mudança da estratégia de controle para a estratégia do comprometimento, sugerem, em última instância, uma deliberação de mudança em nível comportamental nas organizações. Tal deliberação é considerada como condição indubitável para assegurar a operacionalização das 
atividades nas unidades com estruturas organizacionais remotas, segundo os dados desta pesquisa, incluindo todas as unidades.

Reforce-se, ainda com base nos resultados desta pesquisa, que nas unidades com estrutura organizacional remota, a estratégia de comprometimento apresenta-se como o foco relevante. Richard (1997) afiança que, na estratégia de comprometimento se esperam mudanças nas responsabilidades individuais, à medida que as condições mudem e as equipes, não os indivíduos, sejam as unidades organizacionais responsáveis pelo desempenho. Os resultados da pesquisa mostram que a responsabilidade compartilhada em grupos é destaque, incentivado e até premiado, da estrutura organizacional remota, em todas as unidades estudadas.

Dessler (1996) refere-se à comunicação como um dos principais fatores de comprometimento, enfatizando o ouvir e a confiança como bases de efetivação da comunicação de mão dupla. Filósofos e sociólogos, hoje, utilizam esse termo para designar o caráter específico das relações humanas que podem ser relações de participação recíproca ou de compreensão. As transformações na cultura organizacional podem vir a ocorrer por meio da comunicação aberta, na qual as equipes possam passar a: integrar o foco das variáveis das pessoas com o foco nas variáveis da cultura organizacional; desenvolver cultura própria, comprometidas com o processo transformador, a partir das atitudes e dos comportamentos. Em todas as unidades com estruturas organizacionais remotas, aqui pesquisadas, essas bases teóricas encontram comprovação de relevância.

É salientado por Stacey (1991) que onde existe uma clara hierarquia e concentração / exercício do poder com forte compartilhamento dos valores e da cultura, leva a uma forte integração organizacional, caracterizando autoridade e obediência. Os resultados da pesquisa mostram que o poder é exercido de modo a facilitar a integração organizacional e o reconhecimento natural da hierarquia, conforme destacado na unidade de codificação $n^{\circ} .24$ do quadro "Resultado da Análise de Conteúdo", em todas as unidades pesquisadas.

Conforme mostrado na fundamentação teórica, os pesquisadores que tratam da gestão de pessoas, segundo o conceito de competência, afirmam que a gestão de pessoas deve assumir um papel importante no desenvolvimento da estratégia da organização, à medida que cuida com mais propriedade de atrair, manter e desenvolver as competências necessárias à realização dos objetivos organizacionais. 
Em todas as unidades estudadas foi observado um esforço organizacional nessa direção de atrair, desenvolver e reter talentos, considerando a capitalização das competências individuais que agregam valor aos grupos, às unidades e à organização. Sobressaem-se àquelas unidades que já estão empreendendo ações com a perspectiva futura de amenizar as dificuldades de reter os talentos nas regiões, formando a mão-de-obra nativa desde já, a exemplo de Paragominas (quadros $n^{\circ}$ s 06 e 07), Canaã dos Carajás (quadros $n^{\circ}$ s 14 e 15), Niquelândia (quadros $\mathrm{n}^{\circ} \mathrm{s} 30$ e 31) e Três Marias (quadros $\mathrm{n}^{\circ} \mathrm{s} 32$ e 33).

Ao longo dos estudos dos casos foram constatadas diferenças e semelhanças entre as unidades remotas das empresas pesquisadas. Tais diferenças e semelhanças, evidenciadas na análise dos conteúdos das entrevistas de cada uma dessas unidades e condensadas nas ilustrações comparativas entre elas, são resumidas na ilustração $\mathrm{n}^{\circ} .8$, com o propósito de facilitar a visualização das comparações entre os casos investigados.

\section{ILUSTRAÇÃO No. 08 \\ DIFERENÇAS E SEMELHANÇAS ENTRE OS CASOS}

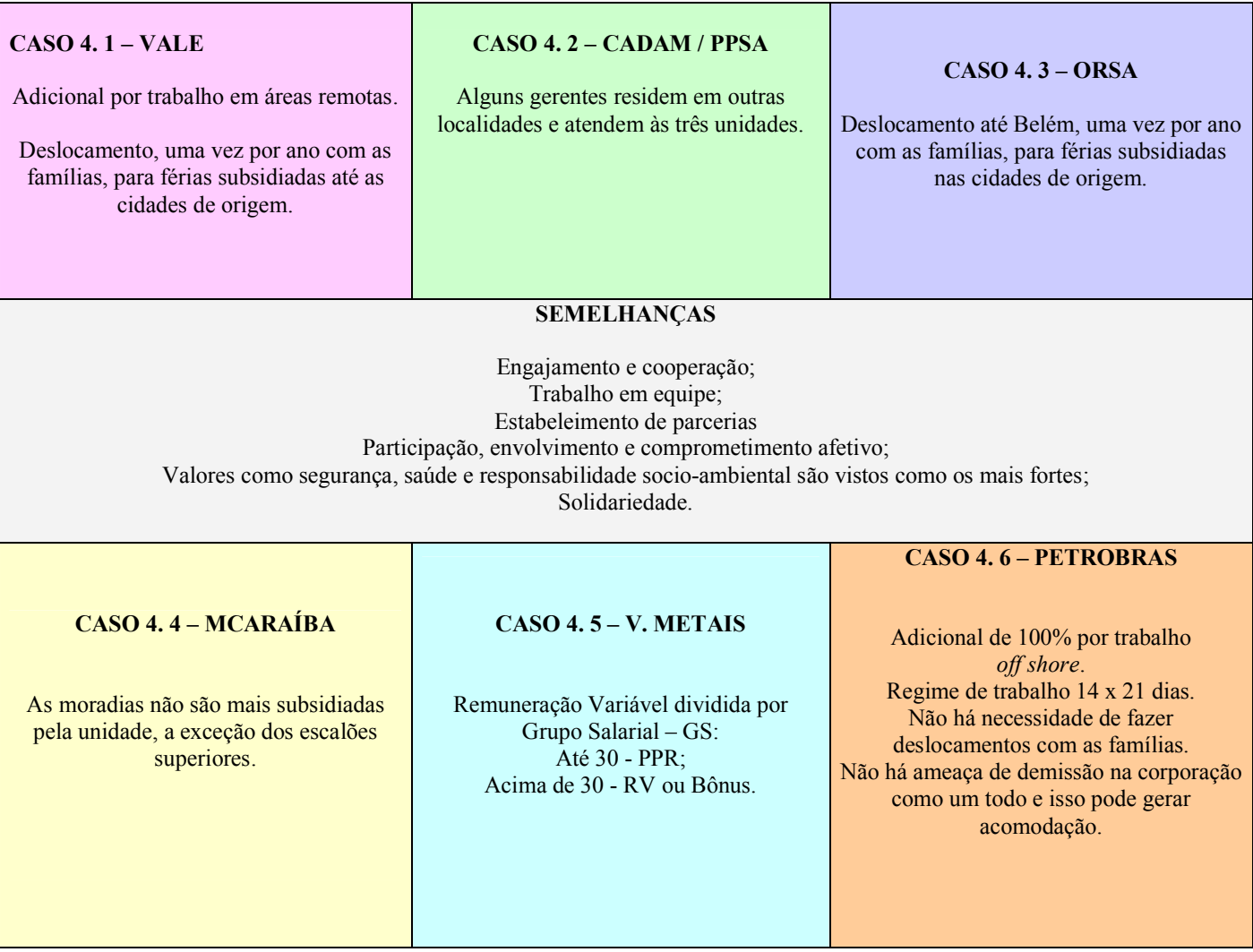


Ressalte-se que, na fundamentação teórica desta pesquisa, o conceito mais próximo das organizações com unidades organizacionais remotas, foi referenciado por Heilbroner (1996), como o proposto por Owen denominado "Aldeias de Cooperação". Heilbroner considerou o trabalho de Owen, como o de um socialista utópico. Em todas essas organizações estudadas, a expressão da utopia foi elucidada com as condições criadas para a convivência cooperativa, exigente de uma ambiência de harmonia, confiança, solidariedade respeito às diversidades, ao meio-ambiente e às comunidades ribeirinhas.

\subsection{Limitações do estudo e contribuições para novas pesquisas}

Enseje-se que esta pesquisa, em cuja natureza qualitativa baseada em estudos de casos múltiplos, encontra, em sua própria natureza, a limitação da falta de possibilidade de generalização dos resultados. As possibilidades de contribuições oriundas desta pesquisa são descritas nos parágrafos subseqüentes.

Foi analisado o nível organizacional. A partir desta pesquisa pode-se contemplar o aprofundamento com: a extensão do número de empresas; a ampliação da visão da administração; a comparação da visão de uma amostra de empregados. Novas unidades com estruturas organizacionais remotas no Brasil e em outros países podem ser investigadas.

Mantendo o foco na pesquisa qualitativa e a investigação, que se constitui no objetivo principal desta pesquisa, pode-se enfatizar, por meio da técnica do grupo focal, não apenas as percepções individuais, mas aquelas oriundas das interações do coletivo, expressas nas estruturas discursivas e na defesa ou crítica de termos e aspectos relevantes desta pesquisa, como forma de verificação dos dados oriundos das entrevistas e das observações.

Instrumentos já validados no Brasil podem ser utilizados para a análise quantitativa, possibilitando a generalização estatística.

Novas pesquisas investigando a influência dos estilos dos gestores na obtenção do comprometimento organizacional podem ser realizadas. 
Além de ampliação do foco ora investigado, na academia, esta pesquisa poderá servir de estímulo para novas investigações nas áreas de administração, sociologia, psicologia, economia e antropologia dentro das estruturas organizacionais remotas.

As empresas poderão desenvolver estudo comparativo das regiões onde tenham unidades remotas instaladas e a influência que essas unidades exercem no desenvolvimento socioeconômico local de cada uma delas.

Para a sociedade, as contribuições residem no retorno obtido por intermédio dos cuidados simultâneos em formação e capacitação de mão-de-obra, educação, responsabilidade socioambiental, saúde e segurança, nas mais diversificadas regiões, pelos recônditos do país. 


\section{CONSIDERAÇÕES FINAIS}

O objetivo desta pesquisa foi investigar como a gestão de pessoas influencia o comprometimento organizacional dentro das unidades com estruturas organizacionais remotas das seis organizações selecionadas, procurando identificar diferenças regionais, de contexto, estratégia de comunicação e comportamentos das pessoas que levam à retenção de talentos.

Seus resultados demonstram a existência de práticas diferenciadas de gestão de pessoas, em razão das especificidades contextuais de cada uma dessas unidades remotas dos seis casos em epígrafe, ainda que as corporações desses casos estejam localizadas em grandes centros urbanos do país e sejam responsáveis pelas diretrizes.

Evidencie-se que a estrutura organizacional remota, em todas essas unidades, favorece a busca da contribuição e o desenvolvimento da solidariedade, desde a adaptação das pessoas ao contexto e à região na qual se inserem, até o ganho coletivo com os resultados operacionais e interpessoais.

Ressalve-se que a participação dos gestores mostrou-se fundamental para ambas as modalidades de resultados, com ênfase adicional ao ganho da percepção resgatada de naturalidade da hierarquia e das humanidades por trás de cada pessoa que ocupa as posições de gestão.

As unidades remotas exigem atenção às peculiaridades da região na qual estão inseridas. Em unidades com os núcleos de moradia mais isolados e confinados, a aproximação das pessoas dá-se dentro e fora do ambiente de trabalho. A contribuição é contínua e interdependente. Em outras, cujos núcleos residenciais são mais integrados com a comunidade, a contribuição vai além dos resultados operacionais, na medida em que incorporam os resultados de integração com a comunidade e com os funcionários de todas as áreas. Há aquelas, ainda, em que o sistema é de hotelaria, não exigem deslocamentos das famílias e o regime de trabalho é bastante diferenciado. Nessas circunstâncias, a colaboração é total, uma vez que o confinamento absoluto desenvolve o espírito de equipe e estreita os laços de união e solidariedade, de modo interdependente. 
Nos seis casos estudados, há a evidência de que, por se tratar de estruturas organizacionais remotas, o nível de comprometimento é elevado e insere-se na perspectiva afetiva preconizada pela literatura. Tal perspectiva é sustentada pelos valores que ajudam a criar a identidade organizacional de cada uma dessas unidades. Essas estruturas tendem a aproximar as pessoas em todas as circunstâncias.

Mais uma vez, destaque-se que os gestores exercem influência direta no processo de obtenção desse comprometimento, facilitando para que esses valores sejam vivenciados por todos, dentro e fora das atividades de trabalho.

Existem semelhanças e diferenças entre as culturas das unidades remotas dessas organizações pesquisadas. As semelhanças residem no trato dado às equipes de trabalho, talhadas com extraordinária diversidade cultural, quer em alto mar, na selva, na caatinga ou no cerrado.

As diferenças evidenciam-se nas práticas de gestão, direcionadas para as necessidades específicas de cada contexto no qual essas unidades estão inseridas, ainda assim permanecendo semelhanças na propagação dos valores como sustentabilidade, segurança, saúde, ética e solidariedade.

Confirme-se a premissa de que, muito embora fatores como o desenvolvimento, que torna determinada região menos inóspita e a revolução tecnológica (comunicação), que reduz as distâncias, os desafios para atração e retenção de talentos (colaboradores) e suas famílias ainda permanecem, salvo nos casos em que os regimes de trabalho são diferenciados, em que as famílias permanecem em seus locais de origem e os atrativos financeiros e do próprio regime de trabalho compensam o afastamento temporário desses colaboradores dos seus lares. 


\section{REFERÊNCIAS}

ABBAGNANO, N. Dicionário de filosofia. São Paulo: Martins Fontes, 2003.

ABREU, Y. I. F.; MENEGON L. F.; MIYAZAKI, M. O comprometimento e seu uso como instrumento de controle e de retenção de talento: uma leitura crítica. In: Anais do XXVII EnANPAD. Atibaia: ANPAD, 2003.

ABREU, L. C. Avaliação do grau de comprometimento dos gerentes e profissionais de nível superior de uma empresa siderúrgica. In: Anais do XXX EnANPAD. Salvador: ANPAD, 2006.

ALBUQUERQUE, L. G. O papel estratégico de recursos humanos. Tese (Livre Docência) - Departamento de Administração da Faculdade de Economia, Administração e Contabilidade. São Paulo: Universidade de São Paulo, 1987

ALBUQUERQUE, L. G. Estratégias de recursos humanos e competitividade. In: VIEIRA, M. M. F.; OLIVEIRA, L.M.B. (Orgs.) Administração contemporânea: perspectivas e estratégias. São Paulo: Atlas, 1999.

ALBUQUERQUE, L. G. A gestão estratégica de pessoas. In: FLEURY, M. T. L. (Coord.) [at $a l$. As pessoas na organização. São Paulo: Editora Gente, 2002.

ALLEN, N. J; MEYER, J. P. The measurement and antecedents of affective, continuance and normative commitment to the organization. Journal of Occupational Psychology. 63, 1-18, 1990.

ALMEIDA, G. O.; SILVA, A. M.; CARVALHO, D. Justiça organizacional: implicações para o burnout. In: Anais do XXX EnANPAD. Salvador: ANPAD, 2006.

ANDION, C. Ser ou estar gerente? Reflexões sobre a trajetória e o aprendizado gerencial. In: Anais do XXVI ENANPAD, Salvador: ANPAD, 2002.

ANTHONY, W. P.; PERREWÉ, P. L.; KACMAR, M. K. Strategic Human Resource Management. Florida: Harcourt Brace Publisher \& Co. 1996.

ANTUNES, E. D.; PINHEIRO, I. A. Sistema de comprometimento organizacional para empresas inovadoras em países de capitalismo tardio. In: Anais do XXIII EnANPAD. Foz do Iguaçu: ANPAD, 1999.

ARGYRIS, C. Knowledge for Action. San Francisco: Jossey-Bass Publisher, 1993. 
AZEVEDO, S. D.; DIAS, S. M. R. O. Mentoria e comprometimento organizacional: o caso de secretárias executivas da Universidade Federal de Pernambuco. In: Anais do XXVI EnANPAD. Salvador: ANPAD, 2002.

BANDEIRA, M. L.; MARQUES, A. L.; TEIXEIRA, R. Validando um instrumento de medida de comprometimento: uma proposta empreendedora voltada para as dimensões acadêmica e empresarial. In: Anais do XXIII, EnANPAD. Foz do Iguaçu: ANPAD, 1999.

BANDEIRA, M. L.; MARQUES, A. L.; VEIGA, R. T. AECT na trilha da modernidade: políticas de recursos humanos influenciando múltiplos comprometimentos. In: Anais do XXIII, EnANPAD. Foz do Iguaçu: ANPAD, 1999 a.

BANDEIRA, M. L.; MARQUES, A. L.; VEIGA, R. T. As dimensões múltiplas do comprometimento organizacional: um estudo na ECT/MG. In: Anais do XXIII, EnANPAD. Foz do Iguaçu: ANPAD, 1999 b.

BARBOSA, S. L.; FARIA, J. H. Comprometimentos: Uma Avaliação Crítica sobre a Práxis Organizacional. In: Anais do XXIV, EnANPAD. Florianópolis: ANPAD, 2000.

BARBOSA, A.C.Q.; FERRAZ, D.M.; ÁVILA, F.B. Recursos humanos em direção ao futuro? A gestão de competências em organizações de telefonia móvel. In: Anais do XXVIII EnANPAD. Curitiba: ANPAD, 2004.

BARDIN, L. Análise de conteúdo. Lisboa: Edições 70, 1977.

BASTOS, A.V. B. Os vínculos indivíduo-organização: uma revisão da pesquisa sobre comprometimento organizacional. In: Anais do XVI EnANPAD. Canela: ANPAD, 1992.

BASTOS, A.V. B. Comprometimento organizacional: um balanço de resultados e desafios que cercam essa tradição de pesquisa. In: Revista de Administração - RAE. Rio de Janeiro: FGV, 1993.

BASTOS, A. V. B.; BRANDÃO, M. G. A. Antecedentes de comprometimento organizacional em organizações públicas e privadas. In: Anais do XVII EnANPAD. Salvador: ANPAD, 1993.

BASTOS, A.V. B. Comprometimento organizacional: A estrutura dos vínculos do trabalhador com a organização, a carreira e o sindicato. Tese de Doutorado. Brasília: UNB, 1994 a.

BASTOS, A.V. B. O conceito de comprometimento: sua natureza e papel nas explicações do comportamento humano no trabalho. In: Organização e Sociedade V.1 No 2, pp. 77-106, Salvador: UFBA, 1994 b. 
BASTOS, A. V. B.; BORGES-ANDRADE, J. E. Comprometimento no trabalho: identificando padrões de comprometimento do trabalhador com a organização, a carreira e o sindicato. In: Anais do XIX EnANPAD. João Pessoa: ANPAD, 1995.

BASTOS, A.V. B. Comprometimento no trabalho: O estado da arte e uma possível agenda de pesquisa. In: Cadernos de Psicologia 1 (1) p. 44-63. Salvador: UFBA, 1996.

BASTOS, A. V. B.; BORGES-ANDRADE, J. E. Padrões de comprometimento no trabalho: um estudo de caso. In: Psicologia: Teoria e Pesquisa, v.12, n. 3, pp. 205-217. Salvador: ISP, 1996.

BASTOS, A. V. B.; BRANDÃO, M. G. A.; PINHO, A. P. M. Comprometimento organizacional: explorando este conceito entre servidores de instituições universitárias no cotidiano de trabalho. In: Anais do XX EnANPAD. Angra dos Reis: ANPAD,1996.

BASTOS, A. V. B.; BRANDÃO, M. G. A.; PINHO, A. P. M. Comprometimento organizacional: uma análise do conceito expresso por servidores universitários no contexto de trabalho. In: Revista de Administração Contemporânea, v.1, n. 2, pp. 97-120. Curitiba: ANPAD, 1997.

BASTOS, A. V. B.; COPQUE, H. F.; SILVA, L. A. V.; VIANA, A. V. Importância de fatores pessoais e organizacionais no vínculo indivíduo-organização. In: Reunião Anual de Psicologia, 27, Ribeirão Preto: USP/FFCLRP, 1997.

BASTOS, A. V. B.; PEREIRA, A. M. Mudanças organizacionais e comprometimento no trabalho. In: Anais do XXI EnANPAD. Rio de Janeiro: ANPAD, 1997.

BASTOS, A.V. B. Comprometimento no trabalho: contextos em mudança e os rumos da pesquisa neste domínio. In: Anais do XXII EnANPAD. Foz do Iguaçu: ANPAD, 1998.

BASTOS, A.V. B.; CORREA, N. C. N.; LIRA, S. B. Padrões de comprometimento com a profissão e a organização: o impacto de fatores pessoais e a natureza do trabalho. In: Anais do XXII EnANPAD. Foz do Iguaçu: ANPAD, 1998.

BASTOS, A.V. B.; COSTA, P. C. R. Os vínculos do trabalhador com a organização e o sindicato: padrões de comprometimento e valores relativos ao trabalho. In: Revista Organizações e Sociedade, v.5, nº 13, pp. 87-105. Salvador: UFBA, 1998.

BASTOS, A. V. B.; BORGES-ANDRADE, J. E. Padrões de comprometimento com o trabalho em diferentes contextos organizacionais. In: Anais do XXIII EnANPAD. Foz do Iguaçu: ANPAD, 1999.

BASTOS, A. V. B.; COSTA, F. M. Múltiplos comprometimentos no trabalho: articulando diferentes estratégias de pesquisa. In: Anais do XXIV EnANPAD. Florianópolis: ANPAD, 2000. 
BASTOS, A. V. B. Padrões de comprometimentos com a profissão e a organização: o impacto de fatores pessoais e da natureza do trabalho. In: Revista de Administração da USP - RAUSP v.35 , nº 4, pp. 88-60. São Paulo: USP, 2000.

BASTOS, A.V. B.; COSTA, F. M. Múltiplos comprometimentos no trabalho: articulando diferentes estratégias de pesquisa. In: Psicologia: Organizações e Trabalho, v.1, n. 1, p. 1141, Trindade: UFSC, 2001.

BASTOS, A. V. B.; BORGES-ANDRADE, J. E. Padrões de comprometimento com o trabalho em diferentes contextos organizacionais. In: Revista de Administração de Empresas - RAE v. 42 , nº 2, pp. 31-42. São Paulo: FGV, 2002.

BASTOS, A.V. B.; SIQUEIRA, M. M. M.; MEDEIROS, C. A. F.; MENEZES, I. G. Comprometimento organizacional. In: SIQUEIRA, M. M. M. e Colaboradores. Medidas do comportamento organizacional: ferramentas de diagnóstico e de gestão. Porto Alegre: Artmed, 2008.

BATAGLIA, W.; FISCHER, R. M. A influência da cultura institucional na transformação organizacional. In: Anais do EnEO. Atibaia: ANPAD, 2004.

BECKER, H. S. Notes on the concepts of commitment. The American Journal of Sociology, 66, 32-40, 1960.

BECKER, B. E., HUSELID, M. A. e ULRICH, D. Gestão estratégica de pessoas com scorecard: interligando pessoas, estratégia e performance. Rio de Janeiro: Campus, 2001.

BECKER, B.; GERHART, B. The impact of human resource management on organizational performance: progress and prospects. The Academy of Management Journal, vol. 39, n. 4, p.779-801, 1996.

BERNARDES, C. Teoria geral das organizações - os fundamentos da administração integrada. São Paulo: Editora Atlas S/A, 1988.

BERTERO, C. O. Cultura organizacional e instrumentalização de poder. In: FLEURY, M. T. L.; FISCHER, R. M. Cultura e poder nas organizações. São Paulo: Editora Atlas, 1989.

BEZERRA, M. F. N.; OLIVEIRA, L. M. B. Espiritualidade nas organizações e comprometimento organizacional. Estudo de caso com um grupo de líderes de agências do Banco do Brasil na cidade de Recife. In: Anais do XXXI EnANPAD. Rio de Janeiro: ANPAD, 2007.

BION, W. R. Experiences in groups and other papers. Tavistock Publications: Londres, 1961. 
BORGES-ANDRADE, J. E.; CAMESCHI, C.; SILVA, M. S. Preditores do comprometimento organizacional em instituições de pesquisa. In: XIX Reunião Anual de Psicologia. Ribeirão Preto: USP FFCLRP, 1989.

BORGES-ANDRADE, J. E.; AFANASIEFF, R. S.; SILVA, M. S. Mensuração de comprometimento organizacional em instituições públicas. In: Programa da XIX Reunião Anual de Psicologia. Ribeirão Preto: Sociedade de Psicologia, 1989.

BORGES-ANDRADE, J. E.; AFANASIEFF, R. S.; SILVA, M. S. Mensuração de comprometimento organizacional em instituições públicas. In: Programa da XXIII Reunião Anual de Psicologia, p. 236. Ribeirão Preto: Sociedade de Psicologia, 1993.

BORGES-ANDRADE, J. E.; CAMESCHI, C.; SILVA, M. S. Preditores do comprometimento organizacional em instituições de pesquisa. In: XXIII Reunião Anual de Psicologia, p. 235. Ribeirão Preto: USP/FFCL, 1993.

BORGES-ANDRADE, J. E. Comprometimento organizacional na administração pública e em segmentos meio e fim. In: Programa da XXIII Reunião Anual de Psicologia, Ribeirão Preto: Sociedade de Psicologia, 1993.

BORGES-ANDRADE, J. E. Conceituação e mensuração de comprometimento organizacional In: Temas de Psicologia, v.1, pp. 37-48. Ribeirão Preto: Sociedade de Psicologia, 1994.

BORGES-ANDRADE, J. E.; PILATI, R. Comprometimento atitudinal e comportamental: relações com suporte e imagem nas organizações. In: Anais do XXIII, EnANPAD. Foz do Iguaçu: ANPAD, 1999.

BORGES-ANDRADE, J. E.; PILATI, R. Comprometimento atitudinal e comportamental: relações com suporte e imagem nas organizações. In: Revista de Administração Contemporânea - RAC, v.5, n.3, pp. 85-106. Curitiba: ANPAD, 2001.

BORGES, L. O.; LIMA, A. M. S.; VILELA, E. C.; MORAIS, S. S. G. Os funcionários não estão comprometidos? In: Anais do XXVI EnANPAD. Salvador: ANPAD, 2002.

BORGES, R. S. G.; MARQUES, A. L.; ADORNO, R. D. Investigando as relações entre políticas de RH, comprometimento organizacional e satisfação no trabalho. In: Anais do XIX EnANPAD. Brasília: ANPAD, 2005.

BOHLANDER, G., SNELL, S. e SHERMAN, A. Administração de recursos humanos. São Paulo: Pioneira Thomson Learning, 2003.

BRITO, A. P. M. P.; BASTOS, A. V. B. O schema de "trabalhador comprometido" e gestão do comprometimento: um estudo entre gestores de uma organização petroquímica. In: Organizações e Sociedade, v.8, n.22, pp. 177-193. Salvador: UFBA, 2001. 
BUCHANAN II, B. Building organizational commitment: the socialization of managers in work organizations. Administrative Science Quartely, 19, 533-546, 1974.

CANÇADO, V. L.; MORAES, L. F. R. Comprometimento organizacional e prática de gestão de recursos humanos: o caso da empresa XSA. In: RAM - Revista de administração Mackenzie, v.7, pp. 11-37. São Paulo: Mackenzie, 2006.

CASADO, T. O indivíduo e o grupo: a chave do desenvolvimento. In: FLEURY, M.T. L. [at al]. As pessoas na organização. São Paulo: Editora Gente, pp. 235 - 246, 2002 a.

CASADO, T. A motivação e o trabalho. In: FLEURY, M.T. L. [at al]. As pessoas na organização. São Paulo: Editora Gente, pp. 247 - 258, 2002 b.

CASADO, T. Comportamento organizacional: fundamentos para a gestão de pessoas. In: R. C. Santos (Org.). Manual de gestão empresarial - conceitos e aplicações nas empresas brasileiras, pp. 212-233. São Paulo: Editora Atlas, 2007.

CASTER, M. Survivor: how hr can survive and thrive in the organization. Organization Development Journal, Chesterland (USA): Summer, 2001.

CAVAlCANTE, C. E.; MEDEIROS, C. A. F. Desenho do trabalho voluntário e comprometimento organizacional: um estudo nas organizações não-governamentares. In: Anais do I EnGPR - Encontro de Gestão de Pessoas e Relações de Trabalho. Natal: ANPAD, 2007.

CHANG Jr., J. Gestão de pessoas através do desenvolvimento do comprometimento organizacional: uma abordagem holística e simultânea dos determinantes envolvidos nesse processo. São Paulo: FEA/USP Tese de Doutorado, 2001.

CHANG Jr., J.; ALBUQUERQUE, L. G. Inovações tecnológicas e o comprometimento Organizacional. In: Anais do X Seminário Latino-Americano de Gestão Tecnológica ALTEC, 2003.

CHANG Jr., J.; ALBUQUERQUE, L. G. Estratégia de comprometimento em gestão de pessoas. In: COSTA, B. K.; ALMEIDA, M. I. R. (Org.) Estratégia direcionando os negócios. São Paulo: Editora. Atlas, pp. 163-174, 2005.

CHANG Jr., J.; SANTOS, S. B. S.; SILVA, B. A.; CHANG, M. S. Comprometimento organizacional afetivo como estratégia operacional no setor de ensino: uma abordagem baseada no modelo Resource-Based View - RBV. In: Anais do I EnGPR - Encontro de Gestão de Pessoas e Relações de Trabalho. Natal: ANPAD, 2007.

CHANG Jr., J.; SANTOS, S. B. S.; SILVA, A. F.; CHANG, M. S.; NOGUEIRA, A. A. Variáveis antecedentes ao comprometimento organizacional afetivo e sua relaçção com o desempenho : uma abordagem estratégica baseada no modelo Resource-Based View - RBV. In: Anais do XXXI EnANPAD. Rio de Janeiro: ANPAD, 2007. 
CHANLAT, J-F. O indivíduo na organização - dimensões esquecidas volume I: São Paulo: Atlas, 1991.

CHANLAT, J-F. O indivíduo na organização - dimensões esquecidas volume II: São Paulo: Atlas, 1993.

CHANLAT, J-F. O significado da pessoa na gestão de recursos humanos: uma perspectiva socio-antropológica. In: Organização \& Sociedade, v. 2, $n^{\circ} 3$, p. 7-34. Salvador: UFBA, 1994.

COOPER, D. R.; SCHINDLER, P. S. Métodos de pesquisa em administração. Porto Alegre: Bookman, 2003.

COSTA, F. M.; BASTOS, A. V. B. Múltiplos comprometimentos no trabalho: os vínculos dos trabalhadores de organizações agrícolas. In: Anais do XIX ENANPAD. Brasília: ANPAD, 2005.

COSTA, F. C.; RIBEIRO, S. R. M.; CUNHA, E. C. B.; NÓBREGA, K. C.; SOUZA, W. J.. Comprometimento organizacional: estudo de caso em uma indústria têxtil. In: Anais do I EnGPR - Encontro de Gestão de Pessoas e Relações de Trabalho. Natal: ANPAD, 2007.

COSTA, C. J. A.; MORAES, L. F. R. As dimensões do comprometimento organizacional: avaliando os casos dos gerentes e vendedores na cidade de Belo Horizonte. In: Perspectivas Contemporâneas, v. 2, pp. 59/ 22-81. Belo Horizonte: 2007.

CRESWELL, J. W. Research design: qualitative, quantitative and mixed methods approach. Tousand Oaks: Sage, 2003.

CRUZ, M. M. Análise de três estilos de comprometimento organizacional em uma empresa do setor de construção civil. In: Anais do XXVI EnANPAD. Salvador: ANPAD, 2002.

DAMÁSIO, A. R. Em busca de espinosa: prazer e dor na ciência dos sentimentos. São Paulo: Companhia das Letras, 2004.

DAVEL, E.; VERGARA, S. C. (org.) Gestão com pessoas e subjetividade. São Paulo: Editora Atlas, 2001.

DAVIDSON, L. Who's investing in hr? Workforce, Costa Mesa: 1999.

DAVIS, K. Human relations in business. New York: McGraw-Hill, 1957.

DAVIS, K. El comportamiento humano em el trabajo. México: McGraw-Hill, 1983. 
DAVIS, S. M. Managing corporate culture. Cambridge: Ballinger Publishing Company, 1984.

DEMO, G. Comprometimento no trabalho: uma síntese do estudo da arte e uma revisão da produção nacional. In: Revista Psicologia Organizações e Trabalho, Vol. 3, $\mathrm{N}^{\mathrm{o}} 2$ Florianópolis: UFSC, 2003.

DENZI, N. K.; LINCOLN, Y. Collecting and interpreting qualitative materials. London: SAGE Publications, 1998.

DENZI, N. K.; LINCOLN, Y. S. Handbook of qualitative research. London: SAGE Publications, 2000.

DERTOUZOS, M. L. et al Made in América: regaining the productive edge. Ninth printing. Cambridge: The MIT Press, 1991.

DESSLER, G. Conquistando comprometimento - como construir e manter uma força de trabalho competitiva. São Paulo: Makron Books, 1996.

DIAS, D. S.; MARQUES, A. L. Múltiplos comprometimentos: um estudo com profissionais e gerentes de uma grande empresa do setor metal-mecânico. In: Anais do XXVI EnANPAD. Salvador: ANPAD, 2002.

DINIZ de SÁ, M. A. D.; LEMOINE, C. O estilo de liderança como fator de comprometimento na empresa. In: Anais do XXII EnANPAD. Foz do Iguaçu: ANPAD, 1998.

DINIZ de SÁ, M. A. D.; LEMOINE, C. Em matéria de comprometimento na empresa são os valores que contam. In: Anais do XXIII EnANPAD. Foz do Iguaçu: ANPAD, 1999.

DUBRIN, A. J. Fundamentals of organizational behavior: an applied perspective. New York: Pergaman Press, 1974.

DUBRIN, A. J. Fundamentos do comportamento organizacional. São Paulo: Pioneira Thomson Learning, 2003. (Tradução: COOK, James Sunderland; LEAL, Marta Malvezzi).

EISENHARDT, K. M. Building Theories from Case Study Research. Academy of Management Review, v.14, no. 4, pp. 532-550, 1989.

FILENGA, D.; SIQUEIRA, M. M. M. O impacto de percepções de justiça em três bases de comprometimento organizacional. In: Revista de Administração da USP - RAUSP, v. 41, nº 4, pp. 431-441. São Paulo: FEA/USP, 2006. 
FISCHER, A. L. O conceito de gestão de pessoas - modismo e realidade em gestão de recursos humanos nas organizações brasileiras. In: DUTRA, J. S. [org.]. Gestão por competências. São Paulo: Editora Gente, 2001.

FISCHER, A. L. Um resgate conceitual e histórico dos modelos de gestão de pessoas. In: FLEURY, M.T. L. [at al]. As Pessoas na Organização. São Paulo: Editora Gente, 2002.

FLEURY, M.T. L. Comprometimento e qualidade: velhos temas e novos desafios na gestão de RH. In: Anais do XVII EnANPAD. Salvador: ANPAD, 1993.

FLEURY, M.T. L. O desvendar a cultura de uma organização. In: FLEURY, M.T. L.; FISCHER, R. M. Cultura e poder nas organizações. São Paulo: Editora Atlas, 1996.

FLEURY, A. C. C.; FLEURY, M. T. L. Aprendizagem e inovação organizacional - as experiências de Japão, Coréia e Brasil. São Paulo: Editora Atlas, 1997.

FLEURY, M.T. L.; SAMPAIO, J. R. Uma discussão sobre cultura organizacional In: FLEURY, M.T. L. [at al]. As pessoas na organização. São Paulo: Editora Gente, p. 283 -294, 2002.

FLEURY, M.T.; FLEURY, A. Alinhando estratégia e competências. In: Revista de Administração de Empresas, vol 44, n.1, p. 44-57, 2004.

FLICK, U. Uma introdução à pesquisa qualitativa. São Paulo: Artmed Editora, 2004.

FONSECA, C. A. M.; BASTOS, A. V. B. Criatividade e comprometimento organizacional: suas relações com a percepção de desempenho no trabalho. In: Anais do XXVI EnANPAD. Salvador: ANPAD, 2002.

FONSECA, C. A. M.; BASTOS, A. V. B. Criatividade e comprometimento organizacional: suas relações com a percepção de desempenho no trabalho. In: Psicologia: Organizações e Trabalho, v.3, n. 1, pp. 61-88. Trindade: UFSC, 2003.

FOSSÁ, M. I. T.; SARTORETTO, P. M. Responsabilidade social e empresarial e comprometimento organizacional: uma relação possível? In: Anais do XXVI EnANPAD. Salvador: ANPAD, 2002.

FREITAS, M. E. Cultura organizacional: formação, tipologias e impacto. São Paulo: Makron Books, 1991.

FREITAS, H. M. R.; CUNHA JR., M. V. M.; MOSCAROLA, J. Pelo resgate de alguns princípios da análise de conteúdo: aplicação prática qualitativa em marketing. Porto Alegre: UFRGS/FCE/PPGA, 1996. 
GOULDNER, H. P. Dimensions of organizational commitment. Administrative Science Quarterly. 4, 468 - 490, 1960.

GUEST, D. E. Human resource management and industrial relations. Journal of Management and Industrial Relations, v. 24, $\mathrm{n}^{\circ}$ 5, p. 503 - 521, 1987.

HANDY, C. B. Como compreender as organizações. Rio de Janeiro: Editora Zahar, 1978.

HANASHIRO, D. M. M. Contribuição do estudo da cultura para uma gestão estratégica de recursos humanos. Tese de Doutorado em Administração. São Paulo: FEA/USP, 1995.

HEILBRONER, R. A história do pensamento econômico (Os Economistas). São Paulo: Nova Cultural, 1996.

KANAANE, R. Comportamento humano nas organizações. O homem rumo ao século XXI. São Paulo: Editora Atlas, 1995.

KIENEN, N.; WOLFF, S. Administrar comportamento humano em contextos organizacionais. In: Psicologia: Organizações e Trabalho. Vol. 2, No 2, p. 11 - 37, 2002.

LACOMBE, B. M. B.; TONELLI, M. J. O que nos dizem os especialistas e o que nos mostram as práticas das empresas sobre os modelos de gestão de recursos humanos. In: Anais do XXIV EnANPAD. Florianópolis: ANPAD, 2000.

LAVILLE, C.; DIONNE, J. A construção do saber: manual de metodologia da pesquisa em ciências humanas. Porto Alegre: Artes Médicas Sul/ Belo Horizonte: EDUFMG, 1999.

LEAVITT, H. J. Managerial psychology. Chicago: University of Chicago Press, 1964.

LEITE, N. P. Da insipiência à incipiência nas ações de recursos humanos: o que é possível apreciar. In: Anais do VII SEMEAD. São Paulo: FEA-USP, 2004.

LEITE, C. F. F. O comprometimento organizacional na gestão pública: um estudo de caso em uma universidade estadual. In: Anais do XXXI EnAPAD. Rio de Janeiro: ANPAD, 2007.

LIMONGI-FRANÇA, A. C. Liderança, poder e comportamento organizacional. In: FLEURY, M.T. L. [at al]. As pessoas na organização, pp. 259 - 269. São Paulo: Editora Gente, 2002.

LIMONGI-FRANÇA, A. C. Comportamento organizacional: conceitos e práticas. São Paulo: Editora Saraiva, 2006.

LORSCH, J. W.; MORSE, J. J. Organizations and their members: a contingency approach. New York, Harper and Row, 1974. 
MABEY, C., SKINNER, D. CLARK, T. Experiencing human resource management. London: Sage Publications, 1998.

MARCONI, M. A.; LAKATOS, E. M. Técnica de pesquisa. São Paulo: Editora Atlas, 1982.

MARQUES, G. M.; MEDEIROS, C. M.; FRANÇA, A. G. C.; RIBEIRO, M. F. Estilos de liderança e comprometimento organizacional: uma aplicação do Multifactor Leadership Questionnaire (MLQ) no Brasil. In: Anais do I EnGPR - Encontro de Gestão de Pessoas e Relações de Trabalho. Natal: ANPAD, 2007.

MARTINS, G. C. P.; ALVES, R. O.; MENNA, H. L. Comprometimento organizacional: evidências em organização do setor bancário do Distrito Federal. In: Anais do XIII EnANPAD. Águas de São Pedro, São Paulo: ANPAD, 1989.

MATHIEU, J.E.; ZAJAC, D.M. A review and meta-analysis of the antecedents, Correlates and consequences of organizational commitment. Psychological Bulletin, 108(2), 171-194, 1990.

McGREGOR, D. O lado humano da empresa. São Paulo: Livraria Martins Fontes Editora Ltda, 1980.

MEDEIROS, C. A. F.; ENDERS, W. T. Validação do modelo de conceitualização de três componentes do comprometimento organizacional: um estudo dos padrões de comprometimento organizacional e suas relações com a performance no trabalho. In: Anais do XXI EnANPAD. Rio de Janeiro: ANPAD, 1997.

MEDEIROS, C. A. F. Comprometimento organizacional, características pessoais e performance no trabalho: um estudo de padrões de comprometimento organizacional. Natal: Dissertação de Mestrado, Universidade Federal do Rio Grande do Norte, 1997.

MEDEIROS, C. A. F.; ENDERS, W. T. Validação do modelo de conceitualização de três componentes do comprometimento organizacional (Meyer e Allen, 1991). In: Revista de Administração Contemporânea - RAC, 2(3), pp.67-87. Curitiba: ANPAD, 1998 a.

MEDEIROS, C. A. F.; ENDERS, W. T. Padrões de comprometimento organizacional e suas características pessoais: como são os comprometidos e os descomprometidos com as organizações? In: Anais do XXII EnANPAD. Foz do Iguaçu: ANPAD, 1998 b.

MEDEIROS, C. A. F.; ENDERS, W. T.; SALES, I. O.; OLIVEIRA, D. L. F.; MONTEIRO, T. C. C. Três (ou quatro) componentes do comprometimento organizacional. In: Anais do XXIII EnANPAD. Foz do Iguaçu: ANPAD, 1999.

MedeIROS, C. A. F.; AlbuQUERQUE, L. G.; SIQUEIRA, M.; MARQUES, G. M. Comprometimento organizacional: o estado da arte da pesquisa no Brasil. In: Anais do XXVI EnANPAD. Salvador: ANPAD, 2002. 
MEDEIROS, C. A. F. Comprometimento organizacional: um estudo de suas relações com características organizacionais e desempenho nas organizações hoteleiras. São Paulo: Tese de Doutorado FEA / USP, 2003.

MEDEIROS, C. A. F.; AlBUQUERQUE, L. G.; MARQUES, G.M.; SIQUEIRA, M. Comprometimento organizacional: um estudo exploratório de seus múltiplos componentes. In: Anais do XXVII EnANPAD. Atibaia: ANPAD, 2003.

MEDEIROS, C. A. F.; ALBUQUERQUE, L. G.; MARQUES, G. M. Comprometimento e desempenho organizacional: um estudo da estrutura de relacionamentos dos componentes do comprometimento com o desempenho das organizações hoteleiras. In: Anais do XXVIII EnANPAD. Curitiba: ANPAD, 2004.

MEDEIROS, C. A. F.; ALBUQUERQUE, L. G.; MARQUES, G. M. Comprometimento organizacional: um estudo de suas relações com as características organizacionais. In: Anais do XXIX EnANPAD. Brasília: ANPAD, 2005.

MELO, E. Comprometimento organizacional, estilos gerenciais e poder organizacional: um estudo relacional. Dissertação de Mestrado. Instituto de Psicologia: Universidade de Brasília.Brasília: UNB, 2001.

MELO, E. A. A.; PAZ, M. G. T.; ALMEIDA, A. M. O. Representação social de vínculo do trabalhador com a organização. In: Anais do XXXI EnANPAD. Rio de Janeiro: ANPAD, 2007.

MENEGON, L. F.; CASADO, T. O contrato psicológico como ferramenta para a gestão de pessoas. In: Revista da Administração - RAUSP, Vol. 41, $\mathrm{N}^{\mathrm{o}}$ 2, p.125-135. São Paulo: FEA-USP, abr./mãe/jun. 2006.

MERRIAN, S. B. Qualitative research and case study applications in education. San Francisco: Jossey-Bass Publishers, 1998.

MEYER, J. P.; ALLEN, N. J. Testing "side bet theory" of organizational commitment: some methodological considerations. Journal of Applied Psychology. 69 (3), 372-378, 1984.

MEYER, J. P.; PAUNONEN, S. V.; GELLATLY, I. R.; GOFFIN, R. D.; JACKSON, D. N. Organizational commitment and job performance: it's the nature of the commitment that counts. Journal of Applied Psychology. 74 (1), 152-156, 1989.

MEYER, J. P.; ALLEN, N. J.; GELLATLY, I. R. Affective and continuance commitment to the organization: evaluation of measures and analysis of concurrent a time-lagged relations. Journal of Applied Psychology. 75 (6), 710-720, 1990.

MEYER, J. P.; ALLEN, N. J. A three-component conceptualization of organizational commitment. Human Resource Management Review. 1, 61-89, 1991. 
MEYER, J. P.; ALLEN, N. J.; SMITH, C. A. Commitment to the organizations and occupations: extension and test of a three-component conceptualization. Journal of Applied Psychology. 78 (4), 538-551, 1993.

MEYER, J. P.; ALLEN, N. J. Commitment in the workplace theory, research and application. Londres: Sage Publications, 1997.

MILES, M. B. Qualitative data as un attractive nuisance: the problem of analysis. Administrative Science Quarterly, Ithaca, 24(4): 590-601, Dec.1979.

MINAYO, M. C. (Org.) Pesquisa social: Teoria, Método e Criatividade. Petrópolis: Editora Vozes, 2004.

MORAES, L. F. R.; MARQUES, A. L.; KILINK, Z. M.; PEREIRA, L. Z.; SANTOS, C. M . Q. Comprometimento organizacional: um estudo de caso comparativo em universidades federais mineiras. In: Anais do XXI EnANPAD. Rio das Pedras: ANPAD, 1997.

MORAES, L. F. R.; MARQUES, A. L.; CORREIA, L. F. Comprometimento organizacional: uma contribuição ao constructo. In: Anais do XXII EnANPAD. Foz do Iguaçu: ANPAD, 1998.

MORAES, L. F. R.; DINIZ DE SÁ; LEMOINE.; BASTOS, A. V. B. . In: Anais do XXII EnANPAD. Foz do Iguaçu: ANPAD, 1998.

MORGAN, G. Imagens da organização. São Paulo: Editora Atlas S.A., 1996.

MORGAN, G.; SMIRCICH, L. The Case for Qualitative Research. Academy of Management Review, v., n.4, p. 491-500, Oct 1980.

MOWDAY, R. T., PORTER, L.W.; STEERS, R. M. Employee organization linkages - the psychology of commitment, absenteeism and turnover. New York: Academic Press, 1982.

MOWDAY, R. T., STEERS, R. M. e PORTER, L.W. The measurement of organizational commitment. Journal of Vocational Behavior. 14, 224-247, 1979.

NADLER, D. A.; HACKMAN, J. R.; LAWLER III, E. E. Comportamento organizacional. Rio de Janeiro: Editora Campus, 1983.

NASCIMENTO, M. R.; CANDATTEN, F.; MACIEL, C. O. Interseções entre clima e comprometimento organizacional: uma análise dos antecedentes, dimensionalidade e encontros entre constructos. In: Anais do II EnEO - Atibaia: ANPAD, 2004.

NUNAN, D. Research methods in language learning. New York: Cambridge University Press, 1994. 
OLIVARES, J. E. L. Uma contribuição ao estudo da interação da estrutura organizacional com a estrutura de carreiras nas organizações: o caso do IPEN. Dissertação de Mestrado em Administração- Faculdade de Economia, Administração e Contabilidade da Universidade de São Paulo. São Paulo: FEA/USP, 1999.

OLIVEIRA, M. A. P. S.; LIMA, S. M. V.; BORGES-ANDRADE, J. E. Comprometimento no trabalho e produção científica entre pesquisadores brasileiros. In: Revista de Administração da USP - RAUSP, v. 34, nº. 3, pp. 12-20. São Paulo: FEA/USP, 1999.

OLIVEIRA, D. P. R. Sistemas, organização e métodos: uma abordagem gerencial. São Paulo: Editora Atlas, 2004.

OLIVEIRA, D. P. R. Sistemas, organização e métodos: uma abordagem gerencial. São Paulo: Editora Atlas, 2004.

PAROLIN, S. R. H.; ALBUQUERQUE, L. G. A criatividade, a inovação e a competência dos gestores: suas relações com o comprometimento organizacional. In: Anais do XXVIII EnANPAD. Curitiba: ANPAD, 2004.

PATTON, M. Q. Qualitative research and evaluation methods. London: Sage Publications, 2002 .

PENA, R. P. M. Ética e comprometimento organizacional nas universidades de Belo Horizonte: face a face com as face's. In: Anais do XIX EnANPAD. João Pessoa: ANPAD, 1995.

PEREIRA, O. G. Fundamentos de comportamento organizacional. Lisboa: Fundação Calouste Gulbenkian, 2004.

PEREIRA, L. Z.; OLIVEIRA, R. C. M. Comprometimento organizacional: um estudo na área de administração pública municipal. In: Anais do XXIV EnANPAD. Florianópolis: ANPAD, 2000.

PETROBRAS - Código de ética do sistema Petrobras. Rio de Janeiro: Petrobras BR, 2006

PETROBRAS - Diretrizes de sustentabilidade para as atividades de exploração e produção da Petrobras na Amazônia. Manaus: Petrobras BR, 2008.

PETROBRAS - A saga do petróleo: o desafio de produzir ouro negro na Amazônia. Manaus: Petrobras BR, 2007.

PILATI, R.; BORGES-ANDRADE, J. E. Comprometimento no trabalho, motivação e estratégias de aplicação como preditores de efetividade de treinamento. In: Anais do XXIX EnANPAD. Brasília: ANPAD, 2005. 
PUTNAM, L.; FAIRHURST, G. Discourse analysis in organizations: issues and concerns. In: JABLIN, F. M.; PUTNAM, L. (Ed.). The New Handbook of Organizational Communication: Advances in Theory, Research and Methods. Thousand Oaks: Sage, 2001.

RABECHI, R.; FILENGA, D. Percepções de justiça e comprometimento organizacional em uma ONG - organização não-governamental. In: Anais do XXIX EnANPAD. Brasília: ANPAD, 2005.

REGO, A.; SOUTO, S. Comprometimento organizacional: um estudo luso-brasileiro sobre a importância da justiça. In: Anais do XXVI EnANPAD. Salvador: ANPAD, 2002.

REGO, A. Climas de justiça e comprometimento organizacional. In: Psicologia: Organizações e Trabalho, v. 3, nº 1, p.27-60. Trindade: UFSC, 2003.

REGO, A.; SOUTO, S. A percepção de justiça como antecedente do comprometimento organizacional: um estudo luso-brasileiro. In: Revista de Administração Contemporânea RAC, Vol. 8, №. 1. Curitiba: ANPAD, 2004.

RICHARD, E. W. Do controle ao comprometimento no local de trabalho. In: Gestão de pessoas, não de pessoal. Série Harvard business review book. Rio de Janeiro: Editora Campus, pp. 95-112, 1997.

RICHARDSON, R. Pesquisa social: métodos e técnicas. São Paulo: Atlas, 1989

ROBBINS, S. P. Comportamento organizacional. São Paulo: Prentice Hall, 2002.

ROBBINS, S. P. Comportamento organizacional. São Paulo: Pearson / Prentice Hall, 2005.

ROCHA, A. S. C.; BASTOS, A. V. B. Comprometimento do empregado e contextos organizacionais em mudança: o caso do Banco do Brasil. In: Anais do XXIII EnANPAD. Foz do Iguaçu: ANPAD, 1999.

RODRIGUES, M. V. C.; ROCHA, N. M. N. Comprometimento organizacional: o caso dos diretores das escolas públicas do Ceará. In: Anais do XVII EnANPAD. Salvador: ANPAD, 1993.

RODRIGUES, M. Comprometimento organizacional: o trabalho como prática sensível de troca. In: Anais do XXV EnANPAD. Campinas: ANPAD, 2001.

ROGERS, C. R. Sobre o poder pessoal. São Paulo: Livraria Martins Fontes Editora Ltda, 1977.

ROGERS, C. R. Um jeito de ser. São Paulo: Editora EPU, 1983. 
ROQUETE, F. F.; SPERLING, L. G. O indivíduo e a organização: um estudo sobre comprometimento dos funcionários da secretaria de estado da saúde de Minas Gerais. In: Anais do EnEO - Encontro de Estudos Organizacionais. Atibaia: ANPAD, 2004.

ROWE, D. E. O.; BASTOS, A. V. B. Comprometimento no Trabalho: Explorando o Conceito, seus Antecedentes e Conseqüentes entre Docentes Universitários. Natal: In: Anais do I EnGPR - Encontro de Gestão de Pessoas e Relações de Trabalho. ANPAD, 2007 (a).

ROWE, D. E. O.; BASTOS, A. V. B. Organizações e/ou carreira? Comparando docentes de IESs públicas e privadas quanto à estrutura de seus vínculos de comprometimento no trabalho. Rio de Janeiro: In: Anais do XXXI EnANPAD. ANPAD, 2007 (b).

RUAS, R. Qualidade total, gestão do trabalho e comprometimento: condições de perspectivas na indústria do Rio Grande do Sul. In: Anais do XX EnANPAD. Angra dos Reis: ANPAD, 1996.

SALANCIK, G. R. Commitment and the control of organizational behavior and belief. In: STAW, B. M.; SALANCIK, G. R. (Ed.) New direction in organizational behavior, pp. 1-54. Chicago: St.Clair, 1977.

SANCHES, E. N. Comprometimento organizacional: um estudo de caso. In: Anais do XXI EnANPAD. Rio das Pedras: ANPAD, 1997.

SANCHES, E. N.; GONTIJO, L. A.; BORBA, A, M.; VERDINELLI, M. A. Metodologia de análise do comprometimento dos professores universitários com a organização e a carreira docente e sua relação com o desempenho. In: Anais do XXIX EnANPAD. Brasília: ANPAD, 2005 .

SANTOS, S. C. C.; OLIVEIRA, R. R. Comprometimento, participação de colaboradores e uso do tempo: o caso do SESC/ PE. In: Anais do XXVI EnANPAD. Campinas: ANPAD, 2001.

SCHEIBLE, A. C. F.; BASTOS, A. V. B. Práticas de gestão do comprometimento em projeto de melhoria do processo de software. Paraná: In: Revista de Práticas Administrativas RPA, Ano 2, v. 2, n. 4. Maringá: UNICORPORE, 2006 a.

SCHEIBLE, A. C. F.; BASTOS, A. V. B. Comprometimento com a carreira: explorando o conceito de entrincheiramento. In: Anais do XXX EnANPAD. Salvador: ANPAD, 2006 b.

SCHEIBlE, A. C. F.; BAStOS, A. V. B.; RODRIGUES, A. C. A. Comprometimento e entrincheiramento: integrar ou reconstruir? Uma exploração das relações entre estes Construtos à luz do Desempenho. In: Anais do XXXI EnANPAD. Rio de Janeiro: ANPAD, 2007.

SCHEIN, E. H. Organizational culture and leadership. São Francisco: Jossey-Bass, 1985.

SCHEIN, E. H. Organizational culture and leadership. São Francisco: Jossey-Bass, 1987. 
SCHEIN, E. H. Organizational culture and leadership. São Francisco: Jossey-Bass, 1992.

SCHERMERHORN JR., J. R.; HUNT, J. G.; OSBORN, R. N. Fundamentos de comportamento organizacional. Porto Alegre: Artmed Editora, 2000.

SCHULER, R. S. JACKSON, S. E. Linking competitions strategies with human resource management practice. Oxford: Academy of Management Executive, 1987.

SELLTIZ; WRIGHTSMAN; COOK. Métodos de pesquisa nas relações sociais. Vol. 2 medidas na pesquisa social. São Paulo: EPU, 2005.

SHRIVASTAVA, P. Integranting Strategy Formulation with Organizational Culture. In: The Journal of Business Strategy, vol. 5, p. 103, 1985.

SILVA, N.; ZANELLI, J. C. Cultura organizacional. In: ZANELLI, J. C.; ANDRADE, J. E. B.; BASTOS, A. V. B. (org.). Psicologia, Organizações e Trabalho no Brasil, pp. 407 442. Porto Alegre: Artmed, 2004.

SIQUEIRA, M. M. M. Considerações acerca das medidas do comprometimento organizacional. In: Anais do XXIV EnANPAD. Florianópolis: ANPAD, 2000.

SIQUEIRA, M. M. M. Comprometimento organizacional afetivo, calculativo e normativo: evidências acerca da validade discriminante de três medidas brasileiras. In: Anais do XXV EnANPAD. Campinas: ANPAD, 2001.

SMITH, A. A riqueza das nações. São Paulo: Editora Nova Cultural, Volume I, 1996.

SOLDI, R. M.; ZANELLI, J. C. Comprometimento organizacional de trabalhadores terceirizados e efetivos: um estudo comparativo em uma empresa de telefonia. In: Anais do XXX EnANPAD. Salvador: ANPAD, 2006.

SOMERS, M. J. Organization commitment, turnover and absenteeism: an examination of direct and interaction effects. Journal of Organizational Behavior, 16, 49-58, 1995.

SOUTO, S. O; REGO, J. A. Espiritualidade nas organizações, produtividade e desempenho. In: Anais do XXX EnANPAD. Salvador: ANPAD, 2006.

SOTO, E. Comportamento organizacional - o impacto das emoções. São Paulo: Pioneira Thomson Learning 2002. (Tradução: MARRAS, J. P.).

STACEY, R. The chaos frontier: creative strategic control for business. Oxford: ButterWorth Heineman, 1991, 
STEIL, A. V.; SANCHES, E. N. Comprometimento organizacional como estratégia de controle. In: Anais do XXII EnANPAD. Foz do Iguaçu: ANPAD, 1998.

STEYART, C.; JANSSENS, M. Human and inhuman resource management: saving the subject of harm organization. The Interdisciplinary Journal of Organizational, Theory and Society, v. 6, nº 2, pp.181-198, 1999.

TEIXEIRA, M.G. Comprometimento organizacional: uma análise dos fatores individuais numa empresa de prestação de serviços. In: Anais do XVIII EnANPAD. Curitiba: ANPAD, 1994.

TELLES, R. A efetividade da "Matriz de Amarração" de Mazzon nas pesquisas em administração. In: RAUSP - Revista de Administração da USP, v. 36, nº. 4, pp.64-72, Outubro / Dezembro, 2001.

THOMPSON, J. D.; van HOUTEN, D. D. As ciências do comportamento: uma interpretação. São Paulo: Atlas, 1975.

TROMPENAARS, F.; HAMPDEN-TURNER, C. Riding the waves of culture. New York: MacGraw-Hill, 1998.

ULRICH, D. Measuring human resources: an overview of practice and prescription for results. Human Resource Management, New York: 36, vol. 3, 1997.

ULRICH, D. Os campeões de recursos humanos: inovando para obter os melhores resultados. São Paulo: Futura, 1998.

ULRICH, D. Recursos humanos estratégicos. São Paulo: Ed. Futura, 2000.

VALADARES, R. C.; SILVA, J. R. G. A influência dos sistemas de gestão de desempenho sobre o cpmprometimento dos indivíduos no atual contexto das organizações. In: Anais do I EnGPR - Encontro de Gestão de Pessoas e Relações de Trabalho. Natal: ANPAD, 2007.

VALENÇA, A. C. Eficácia profissional. Rio de Janeiro: Qualitymark Editora Ltda, 1997

VASCONCELLOS, E.; HEMSLEY, J. R. Estrutura das organizações. São Paulo: Livraria Pioneira Editora / EDUSP, 1986.

VASCONCELLOS, E.; HEMSLEY, J. R. Estrutura das organizações. São Paulo: Pioneira Thomson Learning, 2003.

VASCONCELOS, F. C., A institucionalização das estratégias de negócios: o caso das startups na internet brasileira em uma perspectiva construtivista. In: Revista de Administração Contemporânea - RAC, 8, 2, pp. 159-179. Curitiba: ANPAD, 2004. 
VERGARA, S. C. Métodos de pesquisa em administração. São Paulo: Editora Atlas, 2005.

VIEIRA, M. M. F.; ZOUAIN, D. M. (Org.) Pesquisa qualitativa em administração. Rio de Janeiro: Editora FGV, 2004.

WAGNER III, J. A.; HOLLENBECK, J. R. Comportamento organizacional: criando vantagem competitiva. São Paulo: Saraiva, 2003.

WEIL, P. Organizações e tecnologias para o terceiro milênio: a nova cultura organizacional holística. Rio de Janeiro: Rosa dos Ventos, 1997.

WEINER, Y. Commitment in organization: a normative view. Academy of Management Review, 7 (3), 418 - 428, 1982.

WHEATLEY, M. J. Liderança e a nova ciência. São Paulo: Editora Cultrix, 1992.

WISCOMBE, J. Your wonderful, terrible HR life. Workforce, Costa Mesa: Jun. 2001.

WRIGHT, P. M; McMAHAN, G.; SNELL, S. A. GERHART, B. Comparing line and HR executives' perceptions of HR effectiveness: Services, roles, and contributions. 2001

YEUNG, A. e BERMAN, B. Adding value through human resources: reorienting human resource measurement to drive business performance. Human Resource Management, New York: 31, vol. 3, 1997.

YIN, R. Case study research: design and methods. Oaks: Sage, 1994.

YIN, R. Estudo de caso: planejamento e métodos. São Paulo: Bookman, 2002.

YIN, R. Estudo de caso: planejamento e métodos. São Paulo: Bookman, 2005.

YUKI, G. A. Liderança carismática e transformacional. In: BERGAMINI, C. W.; CODA,R. (Org.) Psicodinâmica da vida organizacional: motivação e liderança. São Paulo: Editora Atlas, 1997.

ZATTI, M. L. R.; MENDES, V. L. P. S. Comprometimento organizacional na área hospitalar e vínculos empregatícios. In: Anais do XXXI EnANPAD. Rio de Janeiro: ANPAD, 2007.

CADAM / PARÁ PIGMENTOS S/A. www.caemi.com.br. Acesso em Dezembro/2007.

COMPANHIA VALE DO RIO DOCE. www.vale.br. Acesso em Janeiro/2008. 
FUNDAÇÃO ORSA. www.fundacaoorsa.org.br. Acesso em Novembro/2007.

JARI CELULOSE. www.jari.com.br. Acesso em Novembro/2007.

MINERAÇÃO CARAÍBA www.minacaraiba.com.br. Acesso em Fevereiro/2008.

PETROBRAS. www 2.petrobras.com.br. Acessos em Março/2008 e Junho/2008.

PROGEP / FIA. www.fia.com.br/progep. Acesso em Junho/2006.

VOTORANTIM METAIS. www.vmetais.com.br. Acesso em Fevereiro/2008. 
APÊNDICE 1 - Roteiro Semi-Estruturado da Entrevista em Profundidade 


\section{Dados Pessoais do Entrevistado}

\begin{tabular}{|l|l|l|}
\hline \multicolumn{1}{|c|}{ Entrevista no. } & Sexo & M \\
\cline { 3 - 3 } & Idade & \\
\hline Empresa/Unidade & \multicolumn{2}{l|}{ Há quanto tempo? } \\
\hline Cargo/ Função & \multicolumn{2}{|l}{} \\
\hline Formação Acadêmica & \multicolumn{2}{l}{} \\
\hline
\end{tabular}

\section{Pontos para Questões}

1. Abertura, comunicação interpessoal e feedback

2. Interações, emoções, pensar, sentir, agir

3. Comportamento intergrupal

4. Participação, envolvimento, engajamento e comprometimento

5. Expectativas

6. Responsabilidades

7. Cooperação

8. Valorização

9. Características da organização

10. Aprendizagem/reaprendizagem

11. Desenvolvimento

12. Incentivos

13. Criação de condições trabalho

14. Missão, visão, filosofia de atuação, valores

15. Acontecimentos críticos

16. Sistema de gestão

17. Poder

18. Políticas de gestão

19. Estrutura e comunicação 
APÊNDICE 2 - Roteiro de Observações 


\section{Dados da Unidade de Análise}

Empresa /Unidade

Região

\section{Roteiro Orientador:}

\section{1. Comportamento Organizacional}

1. Padrões Comportamentais visíveis

2. Atendimento telefônico

3. Acolhimento aos visitantes

4. Tipo de relacionamento

5. Atividades

\section{2. Comprometimento Organizacional}

1. Atitudes ante os horários

2. Geração de informações

3. Relação entre tempo útil e privado/ Distribuição individual/grupal

4. Acordos entre os membros

5. Discursos dos administradores

\section{3. Gestão de Pessoas}

1. Regras formalizadas

2. Regras de gestão das pessoas

3. Regulamento Interno

4. Manuais de procedimentos

5. Festas/Confraternizações

\section{4. Cultura Organizacional}

1. Ambiente construído da organização/arquitetura/layout

2. Modo de as pessoas se vestirem/ linguagem

3. Ritos

4. Logotipo/Quadros

5. Audiovisuais de apresentação 